\title{
ESTRATIGRAFIA DE SEQÜÊNCIAS NA FORMAÇÃO TOMBADOR, GRUPO CHAPADA DIAMANTINA, BAHIA
}

\author{
MARÍLIA RODRIGUES DE CASTRO
}

Orientador: Prof. Dr. Claudio Riccomini

TESE DE DOUTORAMENTO

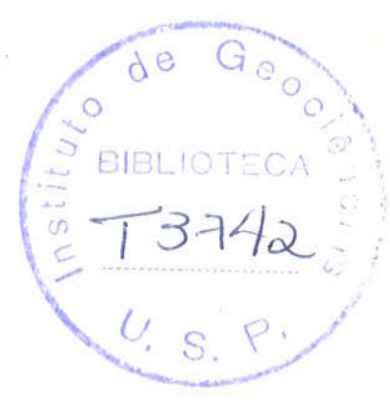

COMISSÃO JULGADORA

Nome

Assinatura

Presidente: Prof. Dr. Claudio Riccomini

Examinadores:

Dr. Augusto José de C. Lima P. da Silva

Dr. Guilherme Pederneiras Raja Gabaglia

Prof. Dr. Jorge Carlos Della Fávera

Prof. Dr. Jorge Hachiro

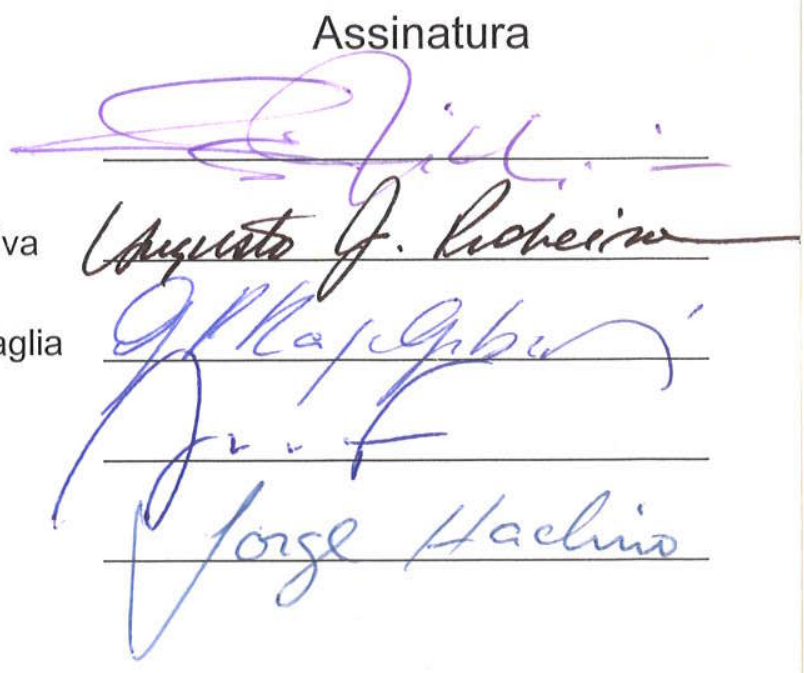

SÃO PAULO

2003 
UNIVERSIDADE DE SÃO PAULO

INSTITUTO DE GEOCIÊNCIAS

ESTRATIGRAFIA DE SEQÜÊNCIAS NA FORMAÇÃO

TOMBADOR, GRUPO CHAPADA DIAMANTINA, BAHIA

MARÍLIA RODRIGUES DE CASTRO

T 3.742

ORIENTADOR: PROF. DR. CLAUDIO RICCOMINI

TESE DE DOUTORAMENTO

PROGRAMA DE PÓS-GRADUAÇÃO EM GEOLOGIA SEDIMENTAR

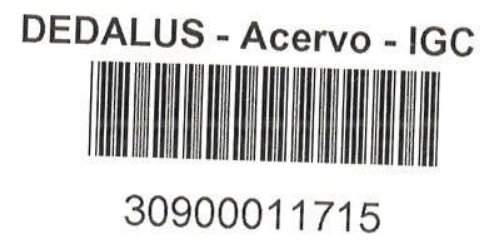

SÃO PAULO

2003 


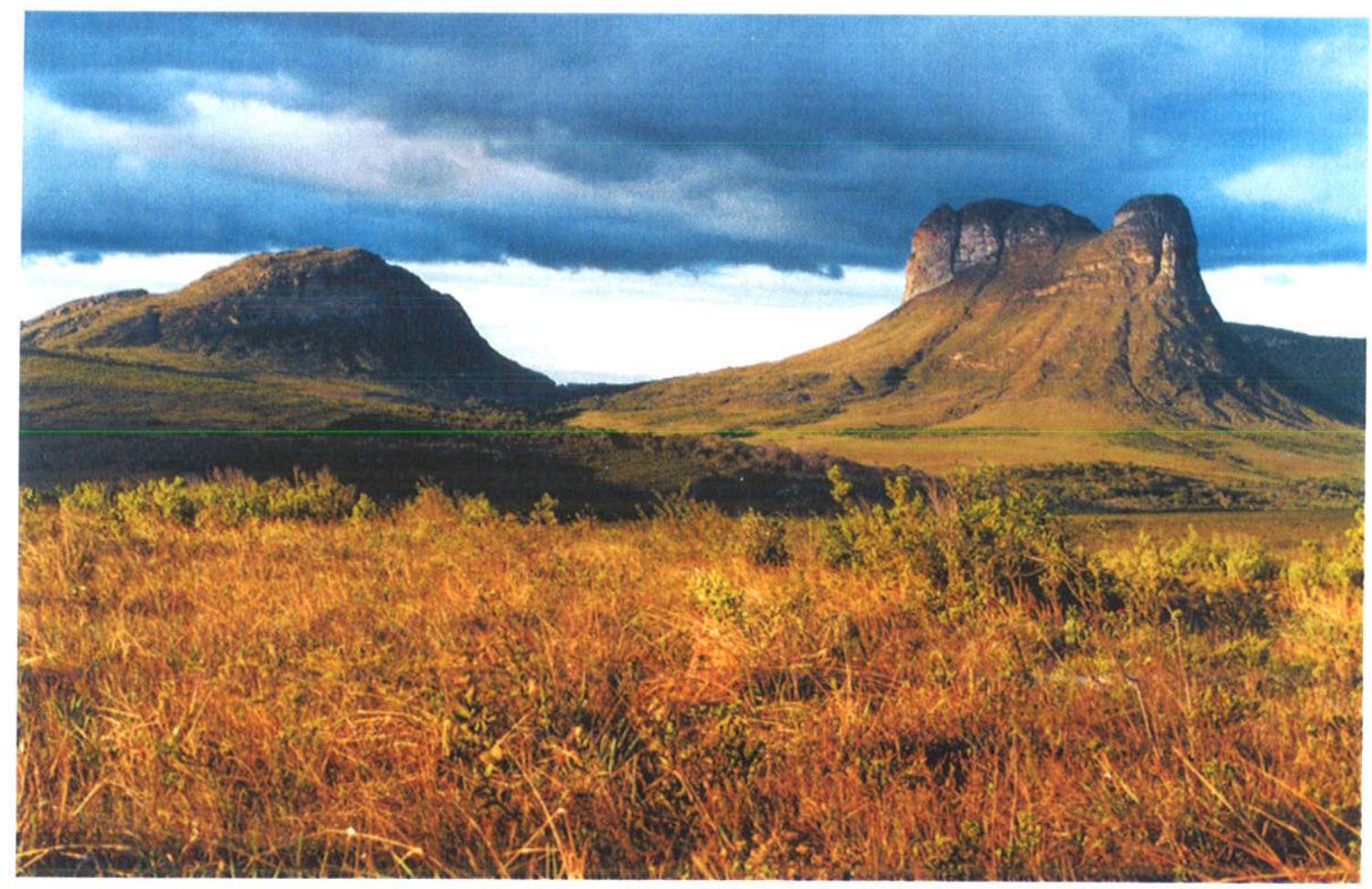

A história da Chapada Diamantina teve início há mais de 1,5 bilhão de anos atrás.

Foi palco de um virtuoso ballet entre rios, estuários, deltas, desertos, mares e até geleiras.

Após essa dança, a chapada sofreu empurrões, falhamentos, soerguimento e um longo período de erosão.

Durante 150 anos foi alvo da ganância dos garimpeiros. Muitos diamantes se foram, mas apesar disso ela não perdeu o brilho, pelo contrário continua majestosa.

Hoje, por trás de suas grutas, cachoeiras, rios e cânions é possivel admirar todo esse registro.

Seus imponentes contrafortes parecem tocar o céu.

Tanto sua fauna como a flora com raras espécies, são exóticas e exuberantes.

Após muita inspiração, é com imenso prazer que apresento aqui uma pequena parte dessa grande história passada num dos mais belos cenários criado pela natureza nesse maravilhoso país chamado Brasil. 


\section{AGRADECIMENTTOS}

Em especial ao meu orientador Claudio Riccomini meus sinceros agradecimentos pela orientação e confiança depositadas.

Ao meu pai Joel, agradeço pela grande ajuda e participação no decorrer do doutorado, inclusive cedendo o próprio carro utilizado nas etapas de campo.

À minha mãe Irinez, pela presença, apoio e auxilio constantes.

Ao Krug pela ajuda imprescindivel na aquisição dos dados no campo.

Ao Carlos José Archanjo pela atenção e incentivo profissional.

Ao Leonardo Borghi e Marco Moraes, responsáveis pela proposta do tema da tese.

A Petrobrás e à geóloga Sílvia dos Anjos por permitir minha participação no treinamento na Chapada Diamantina em setembro de 1999.

A Luci Arienti, Eduardo Rodrigues e principalmente Guilherme Raja Gabaglia pelo ensinamento e discussões.

Ao Instituto Nacional de Pesquisas Espaciais - INPE pela gentil doação da imagem satélite da área de estudo.

Ao Prof. Dr. Paulo Giannini, com quem muito aprendi nas aulas e campos de sedimentologia.

Aos professores Jorge Hachiro e Saad pelas sugestões e criticas apresentadas na qualificação.

Aos colegas de pós-graduação Liliane, Renato, Marcelus, Márcia, Cíntia, Frutinha, Leandro, Sapo, Ana Paula (Nem), Taís, Bruce, Renata, Renato, Ferrari, Paola, Ivo, Choquito, Vítor, Vanessa e Carlos pela alegre e agitada convivência. Em especial ao Afonso que muito me ajudou e ensinou no decorrer do doutorado.

Ao colega Zé Marcelo pela atenção e elaboração dos modelos digitais da área.

Ao geólogo Rodolfo Dino pela análise paleontológica das amostras coletadas na área, infelizmente estéreis.

Ao grande geólogo Benjamim Bley pelo incentivo e constante entusiasmo.

Às secretárias Magali, Ana Paula, Soninha, e ao Tadeu por toda atenção e ajuda.

À FAPESP, Fundação de Amparo à Pesquisa no Estado de São Paulo, pela bolsa e todo o suporte técnico, sem os quais seria inviável a realização dos três anos de doutorado.

Aos meus colegas da ANP e à Agência Nacional do Petróleo por financiar a participação com a apresentação de trabalho referente à tese no $41^{\circ}$ Congresso Brasileiro de Geologia, além de excursões e cursos realizados. 
ÍNDICE.

LISTA DE FIGURAS.

RESUMO...

ABSTRACT

CAPITULO I. INTRODUÇÃO. 1

CAPÍTULO II. MÉTODOS E BASE DE DADOS. 9

CAPÍTULO III. CONTEXTO GEOLÓGICO.

CAPITTULO IV. ESTRATIGRAFIA DE SEQÜÊNCIAS. 20

CAPITULO V. FÁCIES SEDIMENTARES/ASSOCIAÇÕES FACIOLÓGICAS

CAPÍTULO VI. SEQÜENNCIAS DEPOSICIONAIS NA FORMAÇÃO TOMBADOR. .71

CAPÍTULO VII. O ÚLTIMO CICLO DO INTERVALO SUPERIOR, FORMAÇÃO TOMBADOR..93 CAPITULO VIII. DISCUSSÕES. 109

CAPÍTULO IX. CONCLUSÕES 


\section{INDICE}

CAPÍTULO I. INTRODUÇÃO. 1

CAPÍTULO II. MÉTODOS E BASE DE DADOS 9

CAPITULO III. CONTEXTO GEOLÓGICO

CAPITTULO IV. ESTRATIGRAFIA DE SEQÜÊNCIAS 20

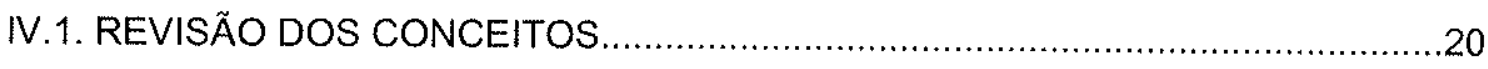

IV.I. ESTRATIGRAFIA DE SEQÜÊNCIAS NO PROTEROZÓICO.

CAPITULO V. FÁCIES SEDIMENTARES/ASSOCIAÇÕES FACIOLÓGICAS

CAPITULO VI. SEQÜENNCIAS DEPOSICIONAIS NA FORMAÇÃO TOMBADOR 71

VI.1. INTRODUÇÃO .71

VI.2. INTERVALO INFERIOR .72

VI.3. SEÇÃO ESTRATIGRÁFICA DO INTERVALO INFERIOR. .81

VI.4. INTERVALO SUPERIOR. .84

VI.5. SEÇÃO ESTRATIGRÁFICA DO INTERVALO SUPERIOR .89

CAPÍTULO VII. O ÚLTIMO CICLO DO INTERVALO SUPERIOR, FORMAÇÃO TOMBADOR..93

VII.1. INTRODUÇÃO. .93

VII.2. PERFIS ESTRATIGRÁFICOS. .93

VII.3. CORRELAÇÃO DOS PERFIS DO ÚLTIMO CICLO 106

CAPITTULO VIII. DISCUSSÕES 109

CAPITULO IX. CONCLUSÕES 


\section{FIGURAS}

\section{CAPÍTULO I. INTRODUÇÃO}

Figura I.1. Mapa de localização da área de estudo 3

Figura I.2. Mapa geológico (Bonfim et al. 1996). 4

Figura 1.3. Mapa mostrando as áreas topograficamente mais elevadas em vermelho e, menos elevadas, em azul).

Figura 1.4. Modelo de elevação digital da área de estudo com vista de sul para norte................5

Figura 1.5. Modelo de elevação digital da área de estudo com vista de norte para sul................5

Figura 1.6. Foto tirada do topo do Morro do Pai Inácio com vista para norte do eixo do Anticlinal do Sincorá. Os paredões são formados por arenitos pertencentes à Fm. Tombador, enquanto na base ocorrem sedimentos da Fm. Guiné. .6

Figura 1.7. Imagem de satélite da área de estudo...........................................................6

Figura 1.8. Kink com plano axial vertical em arenitos (Rio Ribeirão) .......................................6

Figura 1.9. Mapa de localização dos afloramentos descritos.

\section{CAPÍTULO III. TRABALHOS PRÉVIOS}

Figura III.1. Mapa simplificado do Cráton do São Francisco. A: Espinhaço Setentrional, B: Chapada Diamantina, C: Bloco do Paramirim (Savini \& Raja Gabaglia 1997)

Figura 1II.2. Síntese da estratigrafia do domínio da Chapada Diamantina baseada nos trabalhos de Danderfer Filho (1990), Dominguez (1993, 1996), Pedreira (1994) e Misi \& Silva (1996) (Savini \& Raja Gabaglia 1997).

Figura III.3. Geologia simplificada e principais estruturas da Chapada Diamantina (modificado de Danderfer 1990). 16

Figura III.4. Diagrama estratigráfico da Bacia do São Francisco (Medeiros \& Pereira 1994) ....17

Figura III.5. Estratigrafia, sistemas deposicionais e tectônica do Supergrupo Espinhaço na Chapada Diamantina centro-oriental (Pedreira 1997) 19 


\section{CAPITULO IV. ESTRATIGRAFIA DE SEQÜÊNCIAS}

Figura IV.1. Conjuntos de parasseqüências (Van Wagoner et al. 1988). 21

Figura IV.2. Modelos estratais numa seqüência do tipo 1 depositada numa bacia com quebra de plataforma (modificado de Van Wagoner et al. 1988).

Figura IV.3. Modelos estratais numa seqüência do tipo 1 depositada numa bacia tipo rampa (modificado de Van Wagoner et al. 1988).

Figura IV.4. Modelos estratais numa seqüência do tipo 2 (modificado de Van Wagoner et al. 1988) 26

Figura IV.5. Comparação entre a posição do limite na "seqüência deposicional" do grupo da Exxon com o limite na "seqüência estratigráfica genética" de Galloway. A seqüência do tipo 1 e B seqüência do tipo 2 (Miall 1997).

\section{CAPITULO V.FÁCIES SEDIMENTARES/ASSOCIAÇÕES FACIOLÓGICAS}

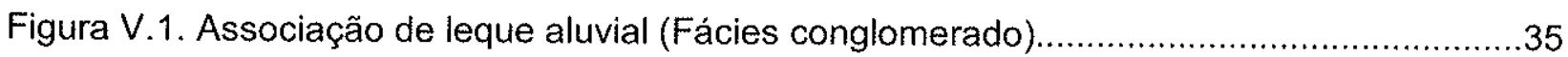

Figura V.2. Associação de leque aluvial (Fácies brecha) ...................................................36

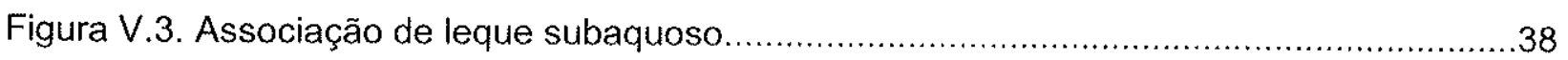

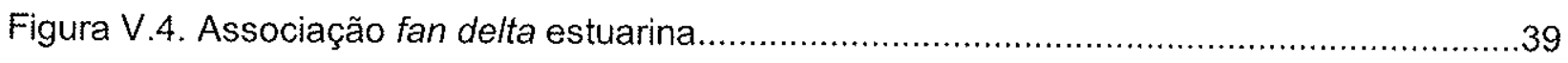

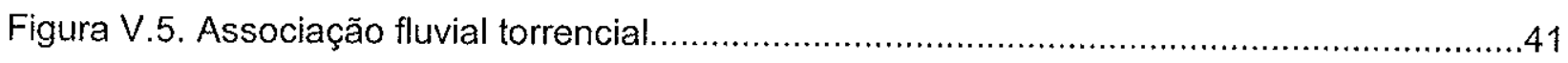

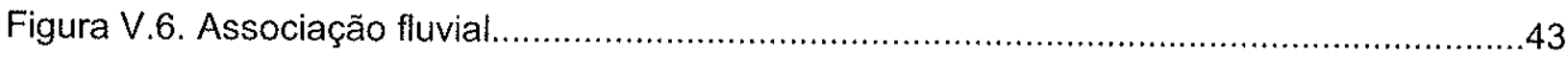

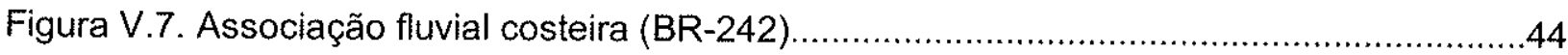

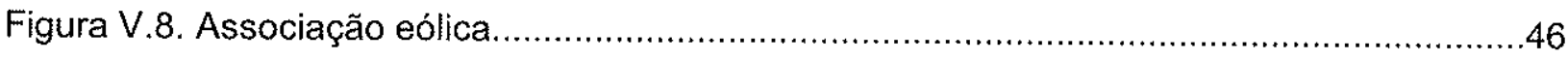

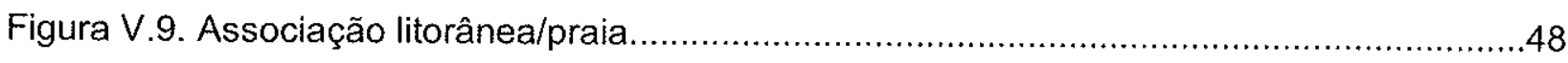

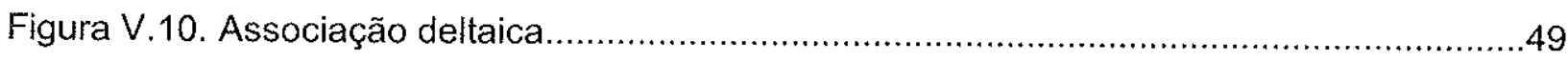

Figura V.11. Associação de frente deltaica (delta de crevasse) .............................................51

Figura V.12. Associação planície deltaica/marinha.........................................................52

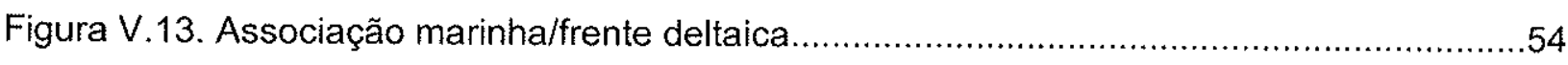

Figura V.14. Associação estuarina-marinha (Rio Ribeirão) ..............................................56

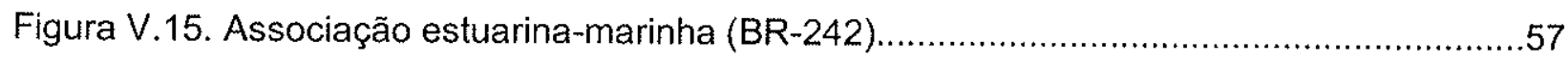

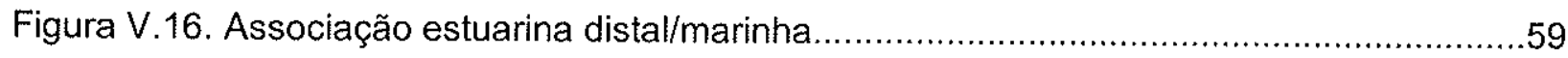

Figura V.17. Associação estuarina distal/marinha, trilha do Morro do Pai Inácio.....................60

Figura V.18. Associação marinha (barra de marés), Morro do Pai Inácio.................................62

Figura V.19. Associação marinha shoreface (margem direita do Rio Capivara)........................64

Figura V.20. Associação marinha shoreface (Fácies arenito e brecha)...................................66

Figura V.21. Associação marinha shoreface (Fácies arenito e brecha) .................................67 


\section{CAPITUULO VI. SEQÜÊNCIAS DEPOSICIONAIS NA FORMACุÃO TOMBADOR}

Figura VI.1. Visão frontal-face leste do Morro do Pai Inácio. Observar as seis superfícies de descontinuidade, bem expressivas, correspondentes a limites de seqüências.

Figura VI.2. Visão lateral (face sul) do Morro do Pai Inácio, mostrando as superfícies de descontinuidade. .73

Figura VI.3. Morro do Camelo. Notar as superfícies de descontinuidade, ou quebras, facilmente traçadas na foto, e semelhantes às do Morro do Pai Inácio. .73

Figura VI.4. Perfil do Morro do Pai Inácio. .75

Figura VI.5. Perfil do intervalo inferior do Rio Mucugezinho. .78

Figura VI.6. Perfil do intervalo inferior do Rio Ribeirão .80

Figura VI.7. Seção estratigráfica do intervalo inferior Pai Inácio, Rio Mucugezinho e Rio Ribeirão. 82

Figura VI.8. Perfil do intervalo superior do Rio Mucugezinho. .85

Figura VI.9. Perfil do intervalo superior do Rio Ribeirão. 88

Figura V1.10. Seção estratigráfica do intervalo superior, rios Mucugezinho e Ribeirão .90

Figura VI.11. Mapa dos afloramentos descritos mostrando a distribuição dos quatro níveis de conglomerado

\section{CAPITULO VII. O ÚLTIMO CICLO DO INTERVALO SUPERIOR. FORMAÇÃO TOMBADOR}

Figura VII.1. Perfil do Rio Capivara .95

Figura VII.2. Perfil do último ciclo do intervalo superior, Rio Ribeirão de Baixo. .97

Figura VII.3. Perfil do Rio Lençóis. 101

Figura VII.2. Perfil do último ciclo do intervalo superior, Rio Mucugezinho. 104

Figura VII.5. Seção estratigráfica dos perfis do último ciclo, intervalo superior da Formação Tombador. 


\section{RESUMO}

A região da Chapada Diamantina é formada por rochas sedimentares do Meso a Neoproterozóico muito bem expostas e preservadas. Nela ocorrem os grupos Rio dos Remédios, Paraguaçu e Chapada Diamantina, inseridos no Supergrupo Espinhaço em sua parte baiana.

Este trabalho tem como enfoque o estudo da Formação Tombador, a qual constitui o intervalo basal do Grupo Chapada Diamantina. A Formação Tombador apresenta contato erosivo com a Formação Guiné sotoposta, e contato gradacional com a Formação Caboclo sobrejacente.

O principal objetivo dessa tese foi o estudo e compreensão da história evolutiva da Formação Tombador na região de Lençóis, por meio de análise faciológica seqüencial de seções colunares de superficie, e de cronocorrelação dessas seções, utilizando-se da Estratigrafia de Seqüências.

Foram descritas 20 fácies sedimentares agrupadas em 16 associações faciológicas relacionadas aos seguintes sistemas deposicionais: leque aluvial, leque subaquoso, fan delta estuarino, fluvial torrencial, fluvial, fluvial costeiro, eólico, litorâneo, deltaico tipo Gilbert, frente deltaica, planície deltaica/marinho, marinho/frente deltaica, estuarino/marinho, estuarino distal/marinho, marinho (barra de marés) e marinho shoreface.

O intervalo inferior da Formação Tombador pode ser subdividido em cinco sequiências deposicionais. Cada seqüência é formada por sistemas fluviais, relacionados ao nível de base baixo, e por sistemas estuarinos (canais) a marinhos (trato de sistemas transgressivo). Em outras seqüências, o trato de nivel baixo pode ser representado por sistemas flúvio-estuarinos ou fluviais com marinhos subordinados. O trato de sistemas transgressivo é formado de sistemas estuário distal e marinho, ou eólico e litorâneo.

Parte dessas seqüências está presente no perfil do Pai Inácio, onde também foram reconhecidas seqüências de alta freqüência ( $4^{\mathrm{a}}$ ordem), e uma grande espessura de depósitos marinhos (barra de marés).

O intervalo superior consiste de quatro tectonosseqüências deposicionais. Cada uma é formada basicamente por um trato de sistemas de nível de base baixo a transgressivo; com a sucessão de sistemas de leque aluvial, fluvial e eólico. Os sistemas fluviais fluiam preferencialmente para oeste, enquanto os ventos apresentavam forte tendência para norte/nordeste. 
O último ciclo do intervalo superior, ou seja, a última tectosseqüência da Formação Tombador foi investigada em detalhe com o levantamento de quatro perfis. O ciclo inicia-se com uma sucessão transgressiva; sistema de leque aluvial sobreposto por sistemas fluvial e deltaico-marinho. Para o sul (Rio Capivara), estes últimos sistemas gradam respectivamente a sistemas de leque subaquoso e marinho de tempestades. Sucede a fase regressiva com sistemas deltaicos e fluviais e localmente litorâneos-eólicos e fluviais (Rio Mucugezinho, ao norte). O ciclo finaliza com nova fase transgressiva, com sistemas flúvio-estuarinos e costeiros evoluindo para o sistema marinho Caboclo. 
The region of Chapada Diamantina in central Bahia is composed of well exposed and preserved sedimentary rocks from Middle to Late Proterozoic. There occurs the Espinhaço Supergroup formed by the Rio dos Remédios, Paraguaçu and Chapada Diamantina groups.

This research has focused on the study of Tombador Formation, which constitutes the basal interval of Chapada Diamantina Group. That unit has more than $500 \mathrm{~m}$ in thickness, with deltaic substrate of Guiné Formation, and gradational contact with the overlying Caboclo Formation.

The main objective of this thesis was to study and understand the evolutive history of Tombador Formation in the Lençóis region, through sequential facies analysis of surface sections, and chronocorrelation of these sections using the Sequence Stratigraphy.

Twenty lithofacies were described and grouped into sixteen facies associations, related to the following depositional systems: alluvial fan, subaqueous fan, fan delta estuarine, torrential fluvial, fluvial, coastal fluvial, aeolian, foreshore, Gilbert-type delta, delta front, delta plain/marine, marine/delta front, estuarine/marine, distal estuarine/marine, marine (tidal bars) and marine shoreface.

The lower interval can be divided into five depositional sequences. Each sequence is formed by fluvial systems related to the low base-level, and by estuarine (channels) to marine systems, transgressive system tract. In other sequences the low base-level is composed of fluvio-estuarine or fluvial and marine systems subordinated. The transgressive system tract is formed by distal estuarine and marine, or aeolian and coastal systems.

Part of these sequences is present in the Pai Inácio section, where sequences of high frequency (fourth order), and thick marine deposits (tidal bars) were recognized.

The upper interval is composed of four tectono sequences. Each one is formed basically of a low base-level system tract to transgressive system tract, with a succession of alluvial fan, fluvial and aeolian.

The fluvial systems flowed to the west, while the wind direction was to north/northeast.

The last cycle of upper interval represents the last tectono sequence of Tombador Formation. It begins with a transgressive succession of alluvial fan, fluvial and delta front to the south (Capivara river section), the latter systems change to subaqueous fan and marine shoreface (tempestite). It follows a regressive succession of deltaic and fluvial, or locally foreshore and aeolian systems overlain by fluvial (Mucugezinho river, to the North). The cycle ends up with a new transgressive succession of fluvial-estuarine and coastal systems which gradually merges into the marine Caboclo Formation. 


\section{CAPÍTULO I}

INTRODUÇÃO

Na Bacia do Espinhaço-São Francisco, implantada sobre o Cráton do São Francisco, acumularam-se os sedimentos pertencentes aos supergrupos Espinhaço e São Francisco. Atualmente é aceito o modelo de um aulacógeno para a acumulação do Supergrupo Espinhaço, com o início da bacia remontando há 1,7 Ga (Dominguez 1993).

O Supergrupo Espinhaço é constituído pelo Grupo Santo Onofre, unidade litoestratigráfica que constitui a Serra do Espinhaço na sua parte baiana, e pelos grupos Rio dos Remédios, Paraguaçu e Chapada Diamantina, que constituem a feição fisiográfica conhecida como Chapada Diamantina. A Chapada Diamantina está dividida em dois domínios principais, Ocidental e Oriental, e a presente tese de doutorado aborda o domínio da Chapada Diamantina Oriental, o qual Almeida et al. (1977) consideraram como uma cobertura plataformal tabular. O Grupo Chapada Diamantina (Proterozóico Médio) é dividido em três formações: Tombador, Caboclo e Morro do Chapéu.

Este estudo enfoca a Formação Tombador, sob a ótica da Estratigrafia de Seqüências, na porção norte do Parque Nacional da Chapada Diamantina. A Formação Tombador é representada por sistemas de leque aluvial, fluvial, eólico, estuarino, litorâneo e marinho shoreface; repousa discordantemente sobre a Formação Guiné (Grupo Paraguaçu), apresentando contato gradacional com a Formação Caboclo sobreposta. Os sistemas pertencentes à Formação Tombador serão analisados detalhadamente para se determinar a arquitetura deposicional e a geometria dos depósitos (suas continuidades lateral e vertical) dentro de um arcabouço cronoestratigráfico de seqüências.

O Grupo Chapada Diamantina pode ser comparado a uma cunha de ciclo de fácies (facies cycle wedge; White 1980) representada por um grande ciclo transgressivo-regressivo de $2^{a}$ ordem, onde o componente transgressivo é constituído pelas formações Tombador e Caboclo, e o regressivo corresponde à Formação Morro do Chapéu.

A Estratigrafia de Seqüências tem um enorme potencial de aplicação para o estudo de acumulações pré-cambrianas, nas quais as datações são geralmente pouco precisas e as correlações bioestratigráficas e cronoestratigráficas tradicionais são comumente problemáticas (Dominguez 1993). 


\section{LOCALIZAÇÃO E FISIOGRAFIA DAÁREA}

A área em estudo localiza-se na Chapada Diamantina, situada na parte central do Estado da Bahia (Figs. 1.1 e 1.2). A Chapada Diamantina está dividida geograficamente em várias serras, como de Rio das Contas, do Bastião, da Mangabeira, das Almas e do Sincorá. A Serra do Sincorá, onde se acha o Parque Nacional da Chapada Diamantina e as cidades de Andaraí, Lençóis, Mucugê e Palmeiras, está localizada na parte central da borda leste da Chapada Diamantina, aproximadamente entre a vila de Afrânio Peixoto (Estiva) ao norte e o Rio Sincorá (entre as cidades de Barra de Estiva e Triunfo do Sincorá) ao sul.

O lado ocidental da Serra do Sincorá é dominado, na parte central, por uma escarpa quase contínua, com aproximadamente $300 \mathrm{~m}$ de altura e mais $80 \mathrm{~km}$ de extensão. O lado oriental da Serra do Sincorá sobe rapidamente da planície da bacia do Rio Paraguaçu (a $400 \mathrm{~m}$ ) até mais que $1200 \mathrm{~m}$ de altitude, nas primeiras cristas da Serra. A orientação da Serra do Sincorá destaca-se como área de relevo montanhoso, com picos de até $1.700 \mathrm{~m}$ (Figs I.3, $1.4 \mathrm{e}$ 1.5).

Na Chapada Diamantina os sedimentos estão dobrados formando o Anticlinal do Sincorá, com eixo de direção NNW-SSE, com cerca de $160 \mathrm{~km}$ de comprimento e 20 a $30 \mathrm{~km}$ de largura, assimétrico, formado durante a inversão da bacia no Neoproterozóico (Fig. I.6). Em toda a área estudada o acamamento tem orientação geral aproximadamente $\mathrm{N}$-S e encontra-se basculado ora para leste (flanco leste do anticlinal) com baixos mergulhos $\left(10^{\circ}\right)$, ora para oeste (flanco oeste do anticlinal) com valores médios de mergulho (até $40^{\circ}$ ).

Através de fotografia aérea e imagem satélite é possivel observar extensas falhas dando origem à serra e seu alinhamento principal norte-sul, embora ela seja cortada por inúmeras falhas e fraturas menores de orientação leste-oeste (Figs. I.7).

As estruturas que afetam as rochas da Formação Tombador são falhas predominantemente inversas, algumas transcorrentes, fraturas (NW, SE e NS), diques (com direção NW e NE), monoclinais suaves e localmente kinks bands (Fig. 1.8). As dobras tipo kinks bands, vistas no Rio Ribeirão (no caminho para a Cachoeira do Sossego), são em S e em $\mathrm{Z}$, com eixo $\mathrm{N} 310^{\circ}$.

Foram estudados afloramentos na região de Lençóis, na porção norte do Parque Nacional da Chapada Diamantina. A feição fisiográfica atual da Chapada se formou pois os rios escavaram vales ingremes e profundos nas formações arenosas, atingindo camadas subjacentes menos resistentes, constituindo verdadeiros cânions e gargantas, e dando origem a inúmeras cachoeiras. Esse padrão de drenagem proporciona excelentes afloramentos ao 
Figura I.1. Mapa de localização da área.

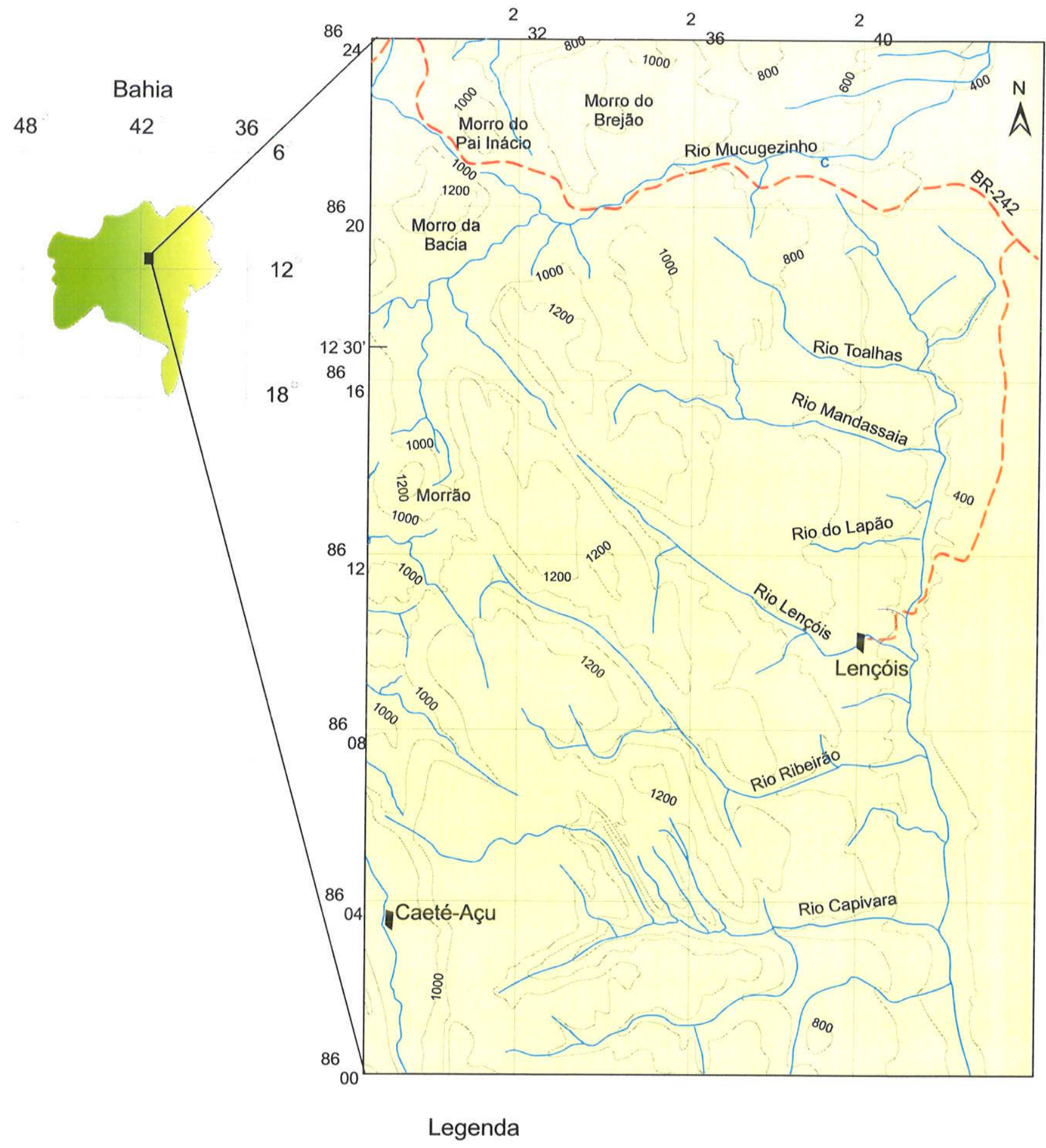

- Cidade

ᄀ. Estrada

$\_$Drenagem

${ }^{1000}$ Curva de Nível 
Figura I.2. Mapa Geológico (Bonfim et al. 1996).

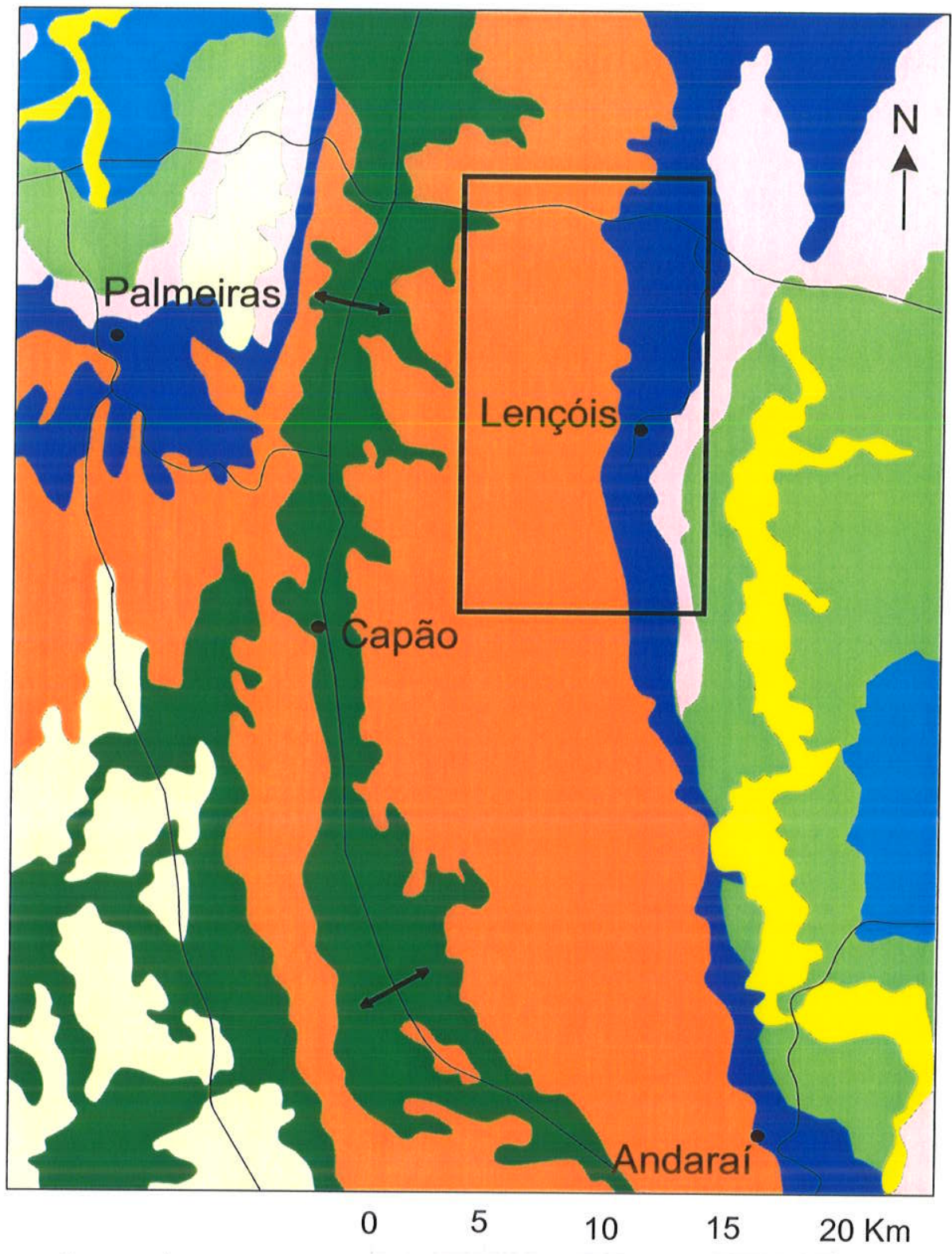

Legenda

Quaternário

Escala

Terciário-Quaternário

Formação Salitre

- Formação Bebedouro Formação Morro do Chapéu Formação Caboclo Formação Tombador Grupo Paraguaçu

- Cidade 
Figura I.3. Mapa mostrando as áreas topograficamente mais elevadas em vermelho e, menos elevadas, em azul.
Figura I.4. Modelo de elevação digital da área de estudo com vista de sul para norte.

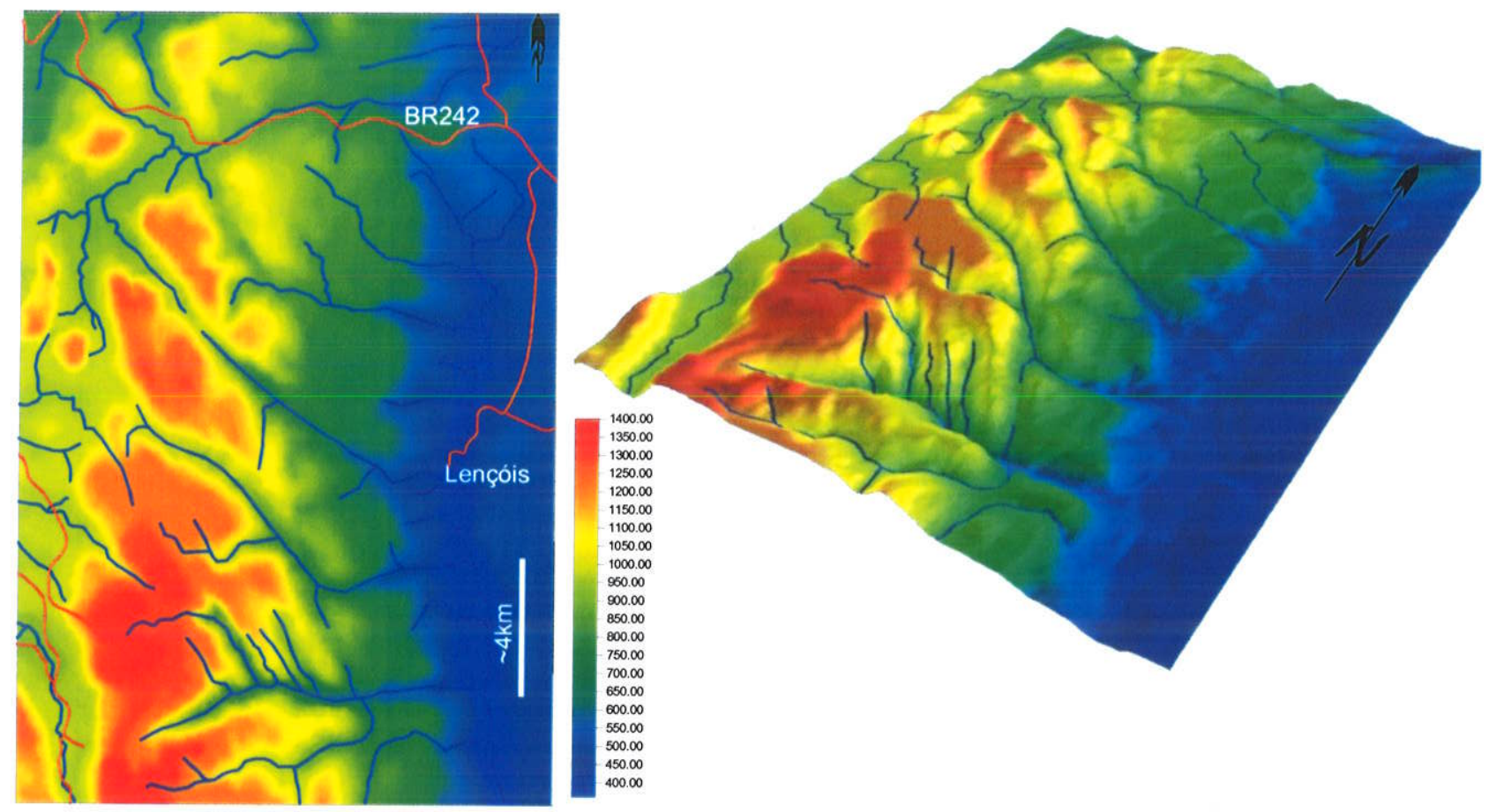

Figura I.5. Modelo de elevação digital da área de estudo com vista de norte para sul.

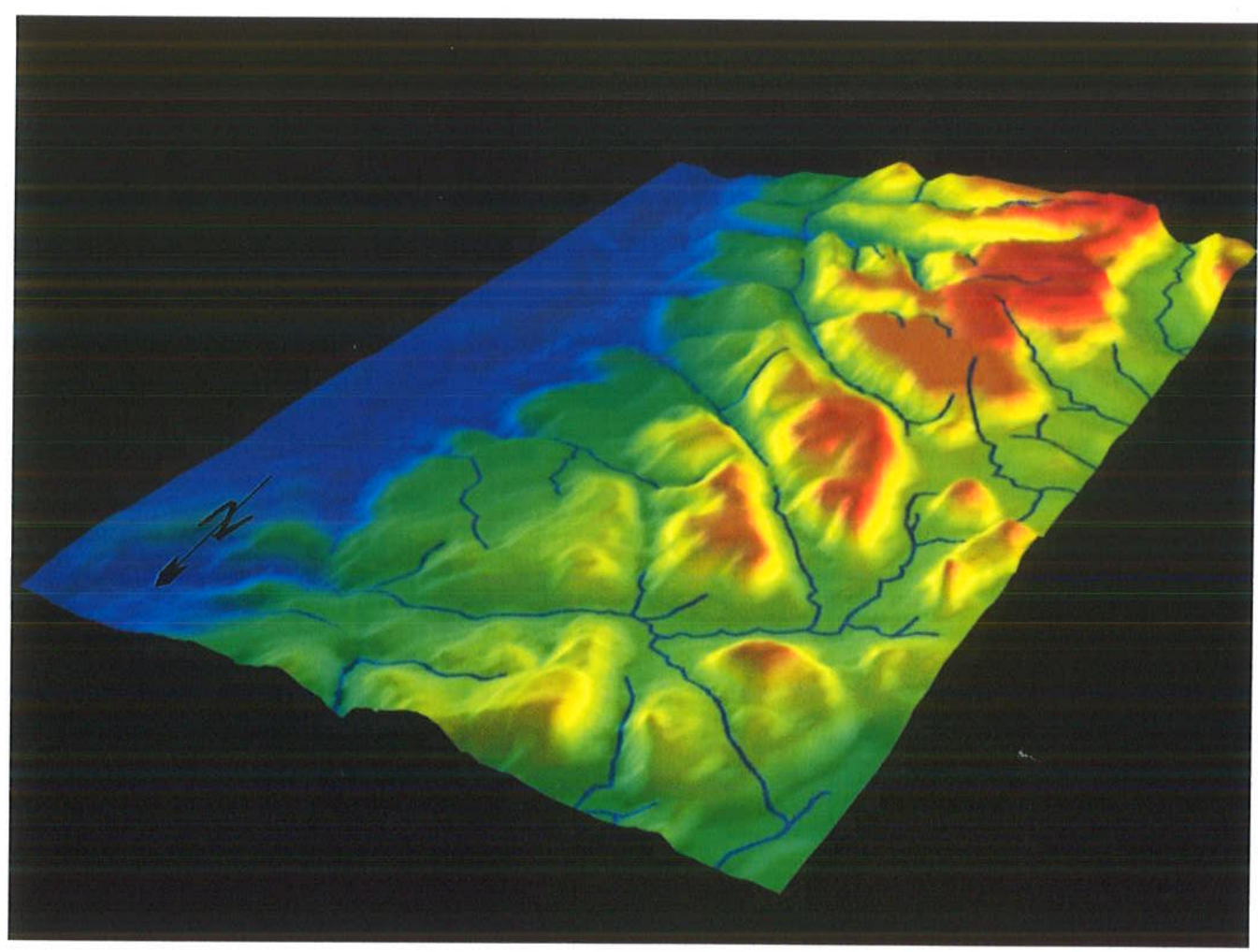


Figura I.6. Foto tirada do topo do Morro do Pai Inácio com vista para norte do eixo do Anticlinal do Sincorá. Os paredões são formados por arenitos pertencentes à Fm. Tombador, enquanto na base ocorrem sedimentos da Fm. Guiné.

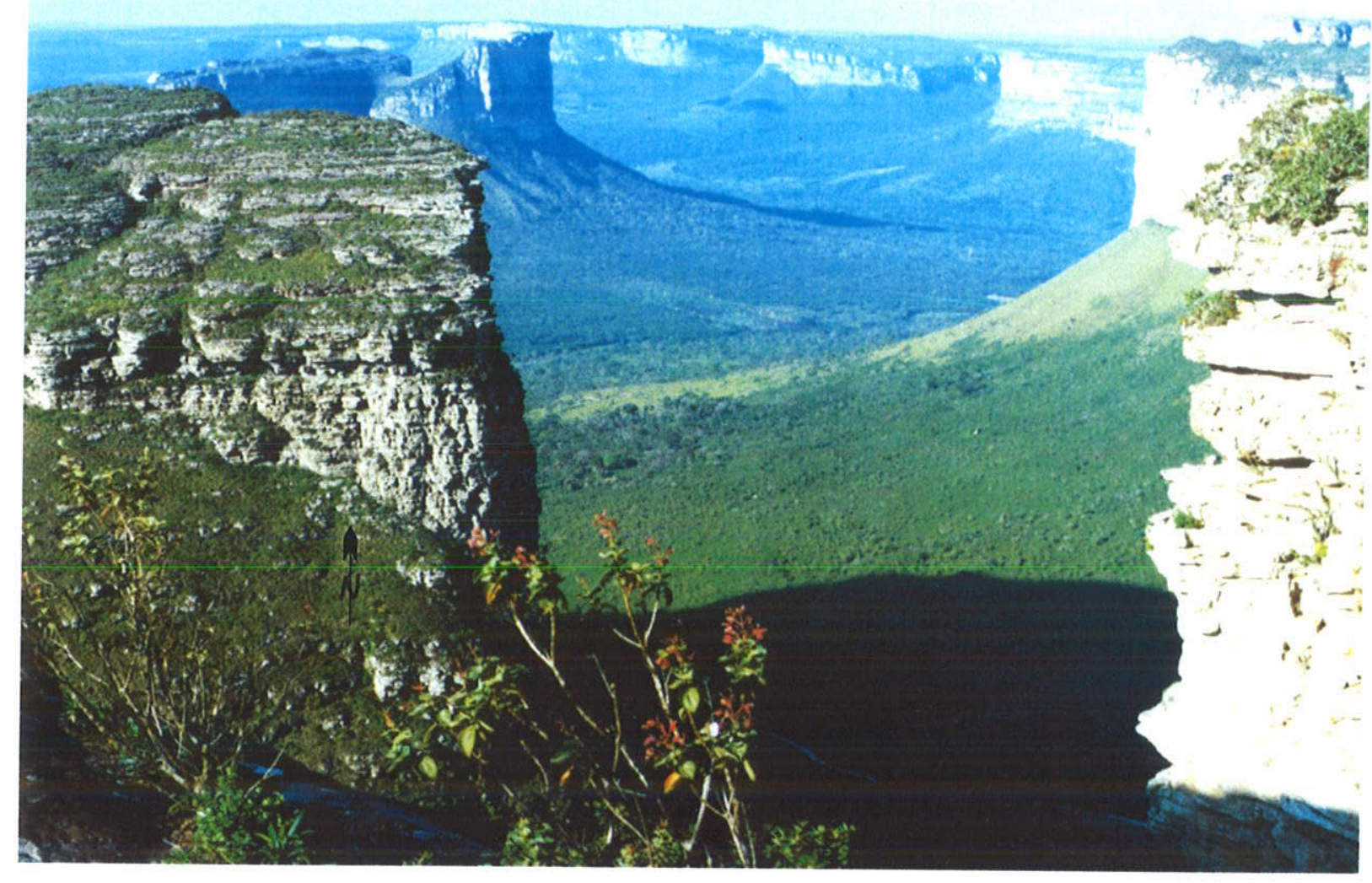

Figura I.7. Imagem de satélite da área de estudo.

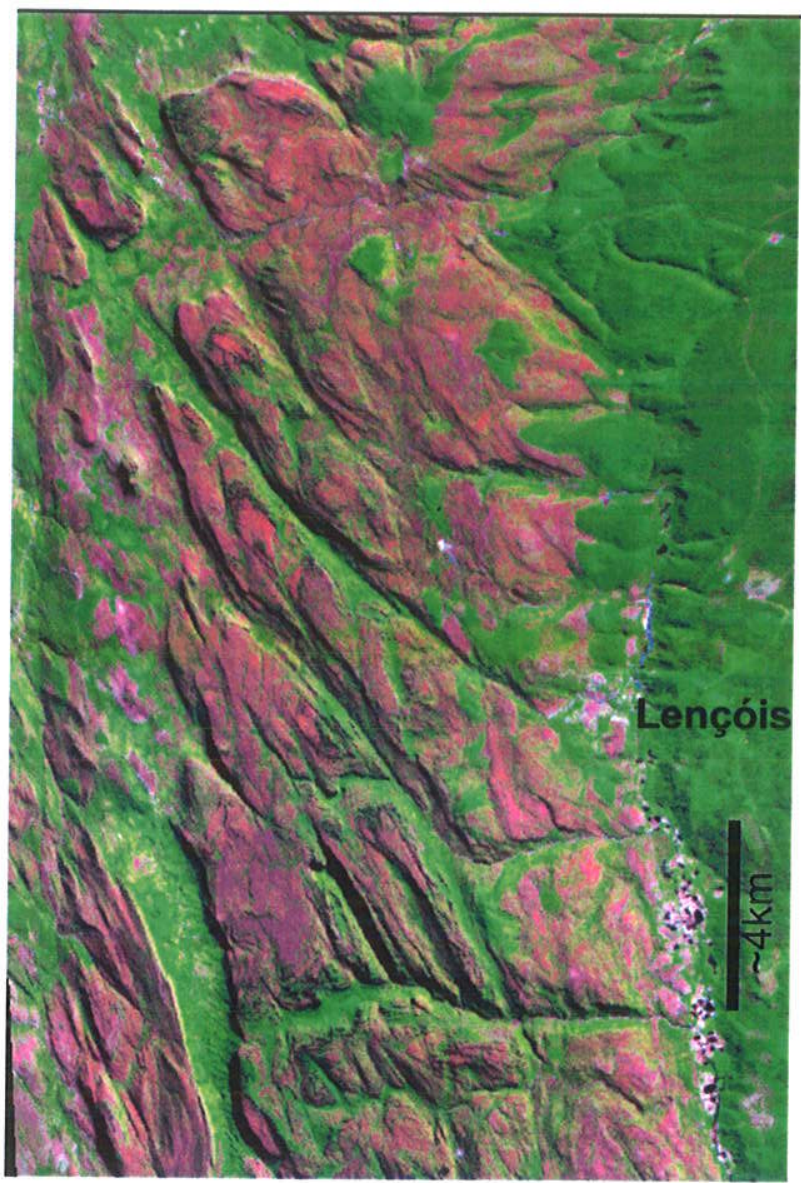

Figura 1.8. Kink com plano axial vertical em arenitos (Rio Ribeirão).

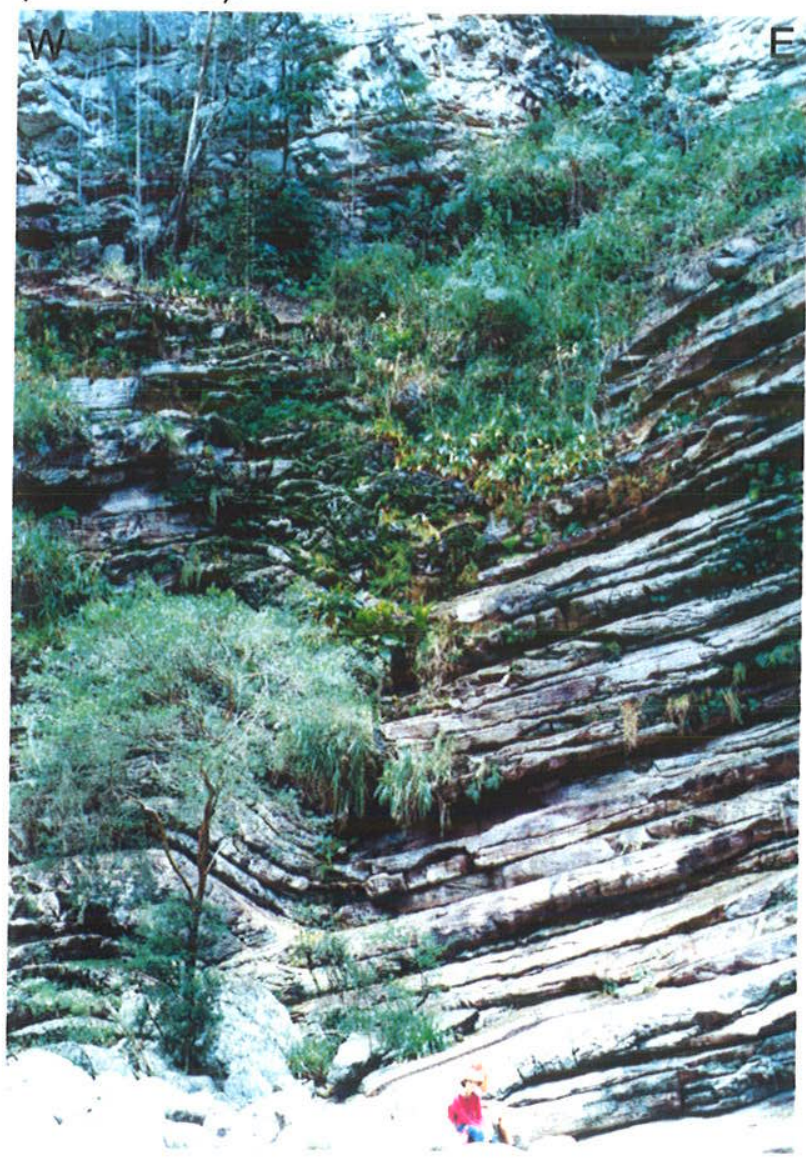


longo dos rios; o empilhamento estratigráfico, por outro lado, é facilitado pelo mergulho das camadas, ligeiramente superior ao mergulho da drenagem, como por exemplo ao longo do flanco leste do Anticlinal do Sincorá. Outros afloramentos são proporcionados pelos flancos dos vales fluviais, principalmente os do Rio Mucugezinho. Neste mesmo vale se encontram bons afloramentos, em cortes ao longo da rodovia BR-242. A figura 1.9 apresenta o mapa com a localização dos afloramentos estudados, descritos no Anexo.

A vegetação da área é geralmente arbustiva, com planaltos de gramíneas e vertentes rochosas onde são freqüentes as cactáceas e bromélias. As chuvas, se não chegam a ser abundantes, ocorrem com freqüência significativa e criam um microclima agradável nessa região, ao contrário do sertão vizinho. Isto é reforçado pelas manhãs quase sempre enevoadas, em parte fornecendo umidade adicional à chapada. 
Figura 1.9. Mapa de localização dos afloramentos descritos.

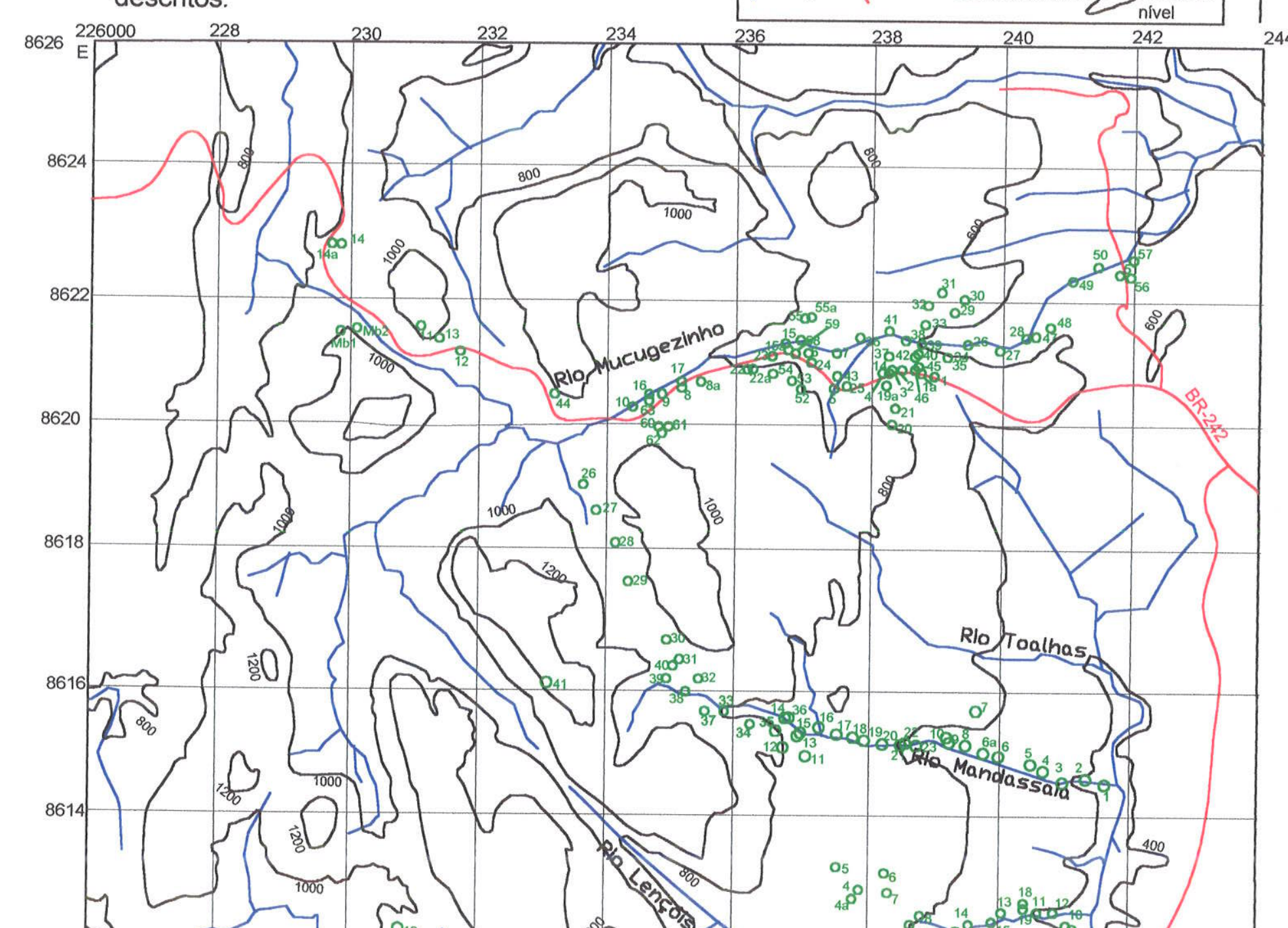




\section{CAPÍTULO II}

\section{MÉTODOS E BASE DE DADOS}

O presente trabalho foi desenvolvido a partir de observações em afloramentos, já que a área não dispõe de dados de subsuperfície (poços e sísmica).

O primeiro passo consistiu na identificação e análise das fácies sedimentares, bem como do entendimento dos processos sedimentares. Fácies é um corpo de rocha com características específicas. Sua definição é baseada na cor, acamamento, composição, textura, fósseis e estruturas sedimentares. Nessa etapa foi feita a análise de paleocorrentes para se obter o sentido das estratificações cruzadas formadas por rios, dunas e também a orientação das cristas de onda, orientadas perpendicularmetes à costa, afim de conhecer o paleoambiente na época de deposição dos sedimentos da Formação Tombador.

O próximo passo foi o agrupamento das fácies em associações faciológicas, baseado fundamentalmente na gênese. A compreensão da fácies, processos sedimentares e associações faciológicas conduz a caracterização dos ambientes, sistemas e arquitetura deposicionais.

A seguir foram elaborados perfis seqüenciais ao longo das drenagens (com direção $\mathrm{EW}$ ) que cortam a área em estudo. As drenagens, por exemplo os rios Mucugezinho, Mandassaia, Lapão, Lençóis, Ribeirão e Capivara, apresentam excelentes extensão e continuidade lateral. As camadas apresentam um mergulho para oeste facilitando o empilhamento ao longo desses rios.

Em seguida os perfis foram correlacionados a partir de uma seção estratigráfica onde finalmente pode-se utilizar o método da Estratigrafia de Seqüências, utilizando-se do modelo da escola da Exxon, onde os limites das seqüências são posicionados nas discordâncias. $O$ método consiste no estudo das relações das rochas dentro de um arcabouço cronoestratigráfico de estratos repetitivos e geneticamente relacionados, e que são limitados por superficies de erosão ou não deposição ou por suas concordâncias correlatas (Van Wagoner et al. 1988). A unidade fundamental é a Seqüência, a qual é limitada por discordâncias e suas concordâncias correlatas. A Seqüência pode ser subdividida em tratos de sistemas, os quais são definidos por sua posição dentro da seqüência e pelos padrões de empilhamento de conjuntos de parasseqüências. Limites de seqüência, de conjunto de parasseqüências e de parasseqüências fornecem um arcabouço cronoestratigráfico para correlação e mapeamento de rochas sedimentares (Van Wagoner et al. 1988). 
Foram coletadas amostras para confecção e análise de lâminas delgadas afim de se observar e estudar as características petrográficas (tipo de cimento, matriz, tamanho do grão).

Algumas amostras de sedimentos finos escuros foram coletadas e analisadas com o objetivo de se obter alguma informação sobre o eventual conteúdo paleontológico. Infelizmente, as amostras se mostraram estéreis. 


\section{CAPÍTULO III CONTEXTO GEOLÓGICO}

A bacia onde se depositaram o Supergrupo Espinhaço e o Grupo Una foi classificada como uma bacia sucessora polihistórica, tendo evoluído de uma fratura interior do continente através de uma depressão interior, para uma depressão de margem continental. Essa margem foi fechada por um evento tectônico do Transamazônico, de modo que a bacia retornou a condições de interior de continente. Essa evolução finaliza-se com a deposição dos sedimentos do Grupo Una em uma bacia do tipo fratura interior, posteriormente deformada (Pedreira 1994).

A Bacia do Espinhaço-São Francisco teve sua origem por volta de $1.7 \mathrm{Ga}$ como um rifte abortado. Nesse rifte se depositaram três seqüências deposicionais na província da Chapada Diamantina: Paraguaçu-Rio dos Remédios, Tombador-Caboclo e Morro do Chapéu; e três outras seqüências na província do Espinhaço Setentrional: Borda Leste, Espinhaço e Gentio (Dominguez 1993). Separando estas bacias encontrava-se o Bloco do Paramirim.

Num primeiro episódio formaram-se as seqüências Paraguaçu-Rio dos Remédios e Borda Leste. Num segundo episódio de subsidência houve a deposição das seqüências Espinhaço e Tombador-Caboclo. Esta subsidência é do tipo térmica-flexural associada a bacias extensionais. Nessa época ocorreram várias oscilações do nível do mar, expondo quase toda a bacia e propiciando a formação de vales incisos na província da Chapada Diamantina (seqüência Morro do Chapéu). Após este episódio ocorreu a glaciação representada pelos sedimentos pertencentes à Formação Bebedouro e com o término da glaciação desenvolveuse uma plataforma carbonática (Formação Salitre).

No Proterozóico Superior houve a inversão da bacia do Espinhaço-São Francisco, causada pelas colisões nas margens do cráton. Durante o Cretáceo, o Cráton do São Francisco foi separado do Cráton do Congo. Essa separação resultou em subsidência favorecendo à acumulação de rochas cretáceas (Dominguez 1993).

Os sedimentos mesoproterozóicos do Supergrupo Espinhaço afloram na porção centronorte do Cráton do São Francisco (domínio Chapada Diamantina), definido por Almeida et al. 1977. O Cráton do São Francisco representa uma área estável desde o final do Ciclo Transamazônico, margeado pelas faixas Brasília, Riacho do Pontal, Rio Preto, Sergipana e Araçuaí, as quais sofreram movimentações durante o Ciclo Brasiliano (Fig. III.1).

A Chapada Diamantina está dividida em dois domínios principais: Ocidental e Oriental (Jardim de Sá et al. 1976). O domínio da Chapara Diamantina Oriental (objeto da tese de doutorado) foi considerado por Almeida et al. (1977) como uma cobertura plataformal tabular. 
Figura III.1. Mapa simplificado do Cráton do São Francisco. A: Espinhaço Setentrional, B: Chapada Diamantina, C: Bloco do Paramirim (Savini \& Raja Gabaglia 1997).

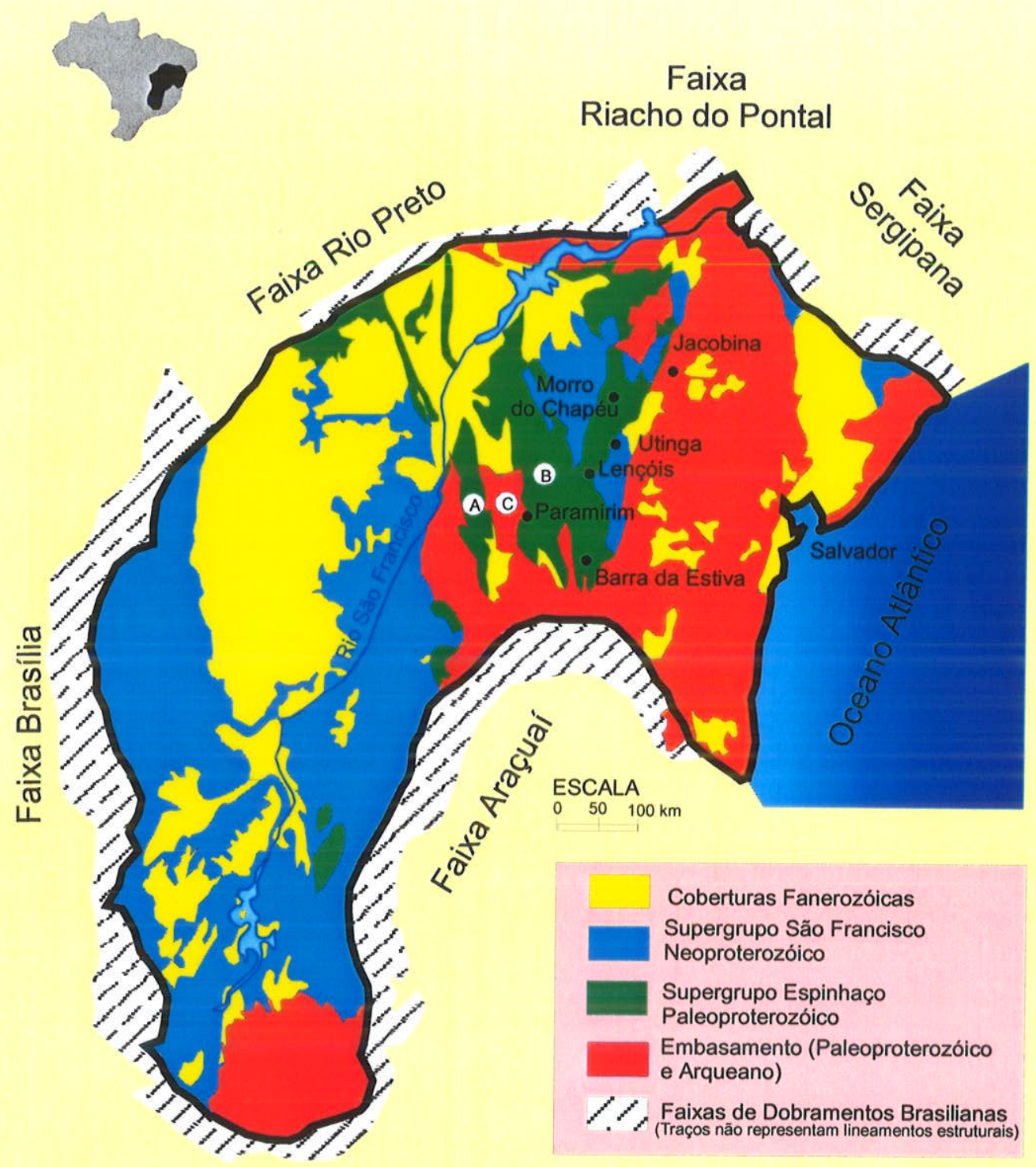


O Supergrupo Espinhaço é constituído pelo Grupo Santo Onofre, unidade litoestratigráfica que constitui a Serra do Espinhaço no Estado da Bahia, e pelos grupos Rio dos Remédios, Paraguaçu e Chapada Diamantina, que constituem a feição fisiográfica conhecida como Chapada Diamantina (Fig. III.2).

Segundo Neves \& Leal (1968) o Grupo Chapada Diamantina é constituído da base para o topo pelas formações Tombador, Caboclo e Morro do Chapéu. As unidades basais do grupo ocorrem em onlap sobre o embasamento cristalino paleoproterozóico-arqueano na região da Escarpa do Tombador. O contato superior tem caráter discordante, evidenciando um hiato deposicional e a presença de processos de erosão, previamente à deposição do Grupo Una, do Neoproterozóico (Medeiros \& Pereira 1994).

A primeira referência à Formação Tombador é de Branner (1910) ao descrever as camadas de arenito que ocorrem sobre o embasamento na Escarpa do Tombador, a oeste de Jacobina. Oliveira \& Leonardos (1940) utilizaram os termos Série e Formação para aquela unidade. Sobreposto ao arenito Tombador, Branner (1910) descreveu uma série de rochas argilosas de cor cinza, vermelho, amarelo e preto, designando-as de Folhelhos Caboclo; Oliveira \& Leonardos (1940) elevaram esta unidade à categoria de Formação. Branner (1910) denominou os sedimentos sobrepostos ao Caboclo de Arenito Lavras; posteriormente, Brito Neves (1967) designou esta unidade de Formação Morro do Chapéu.

Dominguez \& Rocha (1991), Dominguez (1992) e Dominguez (1996) reconheceram duas seqüências deposicionais, ambas do tipo 1, para a região da Chapada Diamantina: (1) Tombador-Caboclo e (2) Morro do Chapéu. O Grupo Chapada Diamantina foi depositado em onlap sobre o embasamento, constituindo uma rampa siliciclástica sem talude bem definido. A seqüência Tombador-Caboclo repousa sobre o embasamento cristalino e durante a deposição, a bacia sofreu um aprofundamento progressivo, com sedimentos eólicos passando para sedimentos marinhos plataformais depositados por ação de tempestades.

Vários episódios de descida do nível do mar ocorreram nesta fase, expondo subaereamente a rampa com a incisão de redes de drenagem; seqüências de mais alta freqüência ocorrem superimpostas à seqüência Tombador-Caboclo. A seqüência Morro do Chapéu é separada da seqüência Tombador-Caboclo por uma discordância com exposição subaérea, associada à formação de um grande vale inciso, constituída por sedimentos fluviais na base passando a estuarinos no topo.

Seguindo as propostas de Dominguez \& Rocha (1991) e de Pedreira (1988), Rocha (1992) utilizou o termo Formação Morro do Chapéu para as seqüências deposicionais que ocorreram discordantemente preenchendo vales escavados na Formação Caboclo. Segundo Rocha (1992) os registros sedimentares das associações de litofácies, que integram principalmente as formações Caboclo e Morro do Chapéu, são condicionados pelas variações 
Figura III.2. Síntese da estratigrafia do domínio da Chapada Diamantina baseada nos trabalhos de Danderfer (1990), Dominguez (1993, 1996), Pedreira (1994) e Misi \& Silva (1996) (Savini \& Raja Gabaglia 1997).

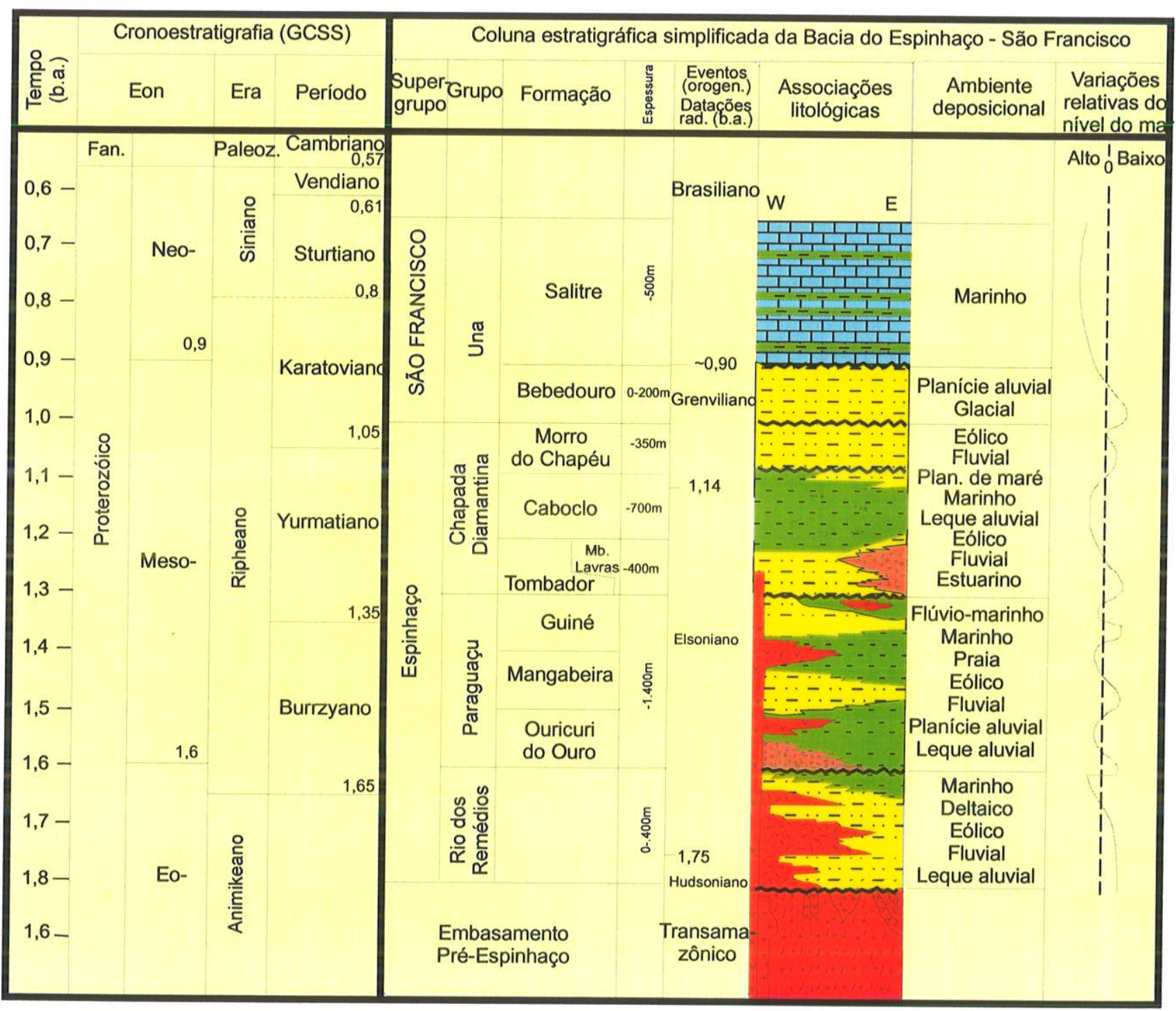


eustáticas do nivel do mar, e pelo menos quatro eventos de abaixamento relativo do nível do mar teriam ocorrido durante a deposição dos sedimentos deste intervalo.

Castro (1993) discute alguns pontos apresentados por Dominguez (1992, 1993), como por exemplo, o lapso de tempo associado às seqüências reconhecidas, os tipos de superficies limitantes, as características das seqüências, além da origem glácio-eustática atribuída aos limites de algumas seqüências. A quase totalidade das seqüências definidas por Dominguez (1992) são do tipo 1 , não tendo sido identificada nenhuma do tipo 2 , talvez por ser de difícil reconhecimento. Castro (1993) critica Dominguez (1992) por não ter diagnosticado mudanças nos padrões de empilhamentos das parasseqüências e ter inserido superfícies limitantes (discordâncias) dentro de sistemas deposicionais. Outro importante fator, com relação à origem glácio-eustática atribuída aos limites de algumas seqüências, é que no Mesoproterozóico não há registro de glaciação (Eyles 1993) e, dessa forma, não há como se fazer a associação entre os limites de seqüência e os eventos glácio-eustáticos; também não existem datações para a Formação Morro do Chapéu, e as idades para as formações Caboclo e Bebedouro (de origem glacial) não são conclusivas.

Na região da Chapada Diamantina, o padrão estrutural dominante é caracterizado por um sistemas de dobras e falhas de empurrão de orientação preferencial NNW-SSE a N-S (Danderfer Filho 1990). Danderfer Filho (1990) individualizou quatro domínios estruturais com características distintas: domínios Morro do Chapéu, Irecê, Gentio do Ouro e Piatã. A geologia simplificada e as principais estruturas podem ser vistas na figura III.3.

Através de estudos de análise estrutural realizados no domínio da Chapada Diamantina, Danderfer Filho et al. (1993) caracterizaram um sistema de dobramentos e empurrões estruturados em duas etapas de deformação distintas $\left(E_{1}\right.$ e $\left.E_{2}\right)$ relativas ao evento Brasiliano. As estruturas da etapa $E_{1}$ compreendem dobras subregionais de duplo caimento, falhas de empurrão e outras feições de menor escala, todos com orientação para NNW-SSE e vergência para ENE. As deformações mais intensas concentram-se na porção sudoeste da Chapada Diamantina, onde o embasamento também foi afetado. As estruturas da etapa E2 se formaram por compressão de norte para sul e estão restritas a porção norte da Chapada Diamantina.

A etapa $E_{1}$ estaria relacionada à inversão do aulacógeno do Espinhaço por um mecanismo induzido a partir das faixas de dobramento brasilianas que circundam o Cráton do São Francisco a norte e a sudeste. A etapa $E_{2}$, seria uma manifestação do cráton dos processos geradores das faixas Rio Preto e Riacho do Pontal, situadas a norte do cráton (Danderfer Filho et al. 1993).

$\mathrm{Na}$ região de Jacobina-Morro do Chapéu-Lençóis, porção central da Chapada Diamantina, Medeiros \& Pereira (1994) apresentaram uma evolução sedimentar para o Grupo Chapada Diamantina através de uma seqüência de eventos (Fig. III.4). No topo da Formação 
Figura III.3. Geologia simplificada e principais estruturas da Chapada Diamantina (modificado de Danderfer 1990).

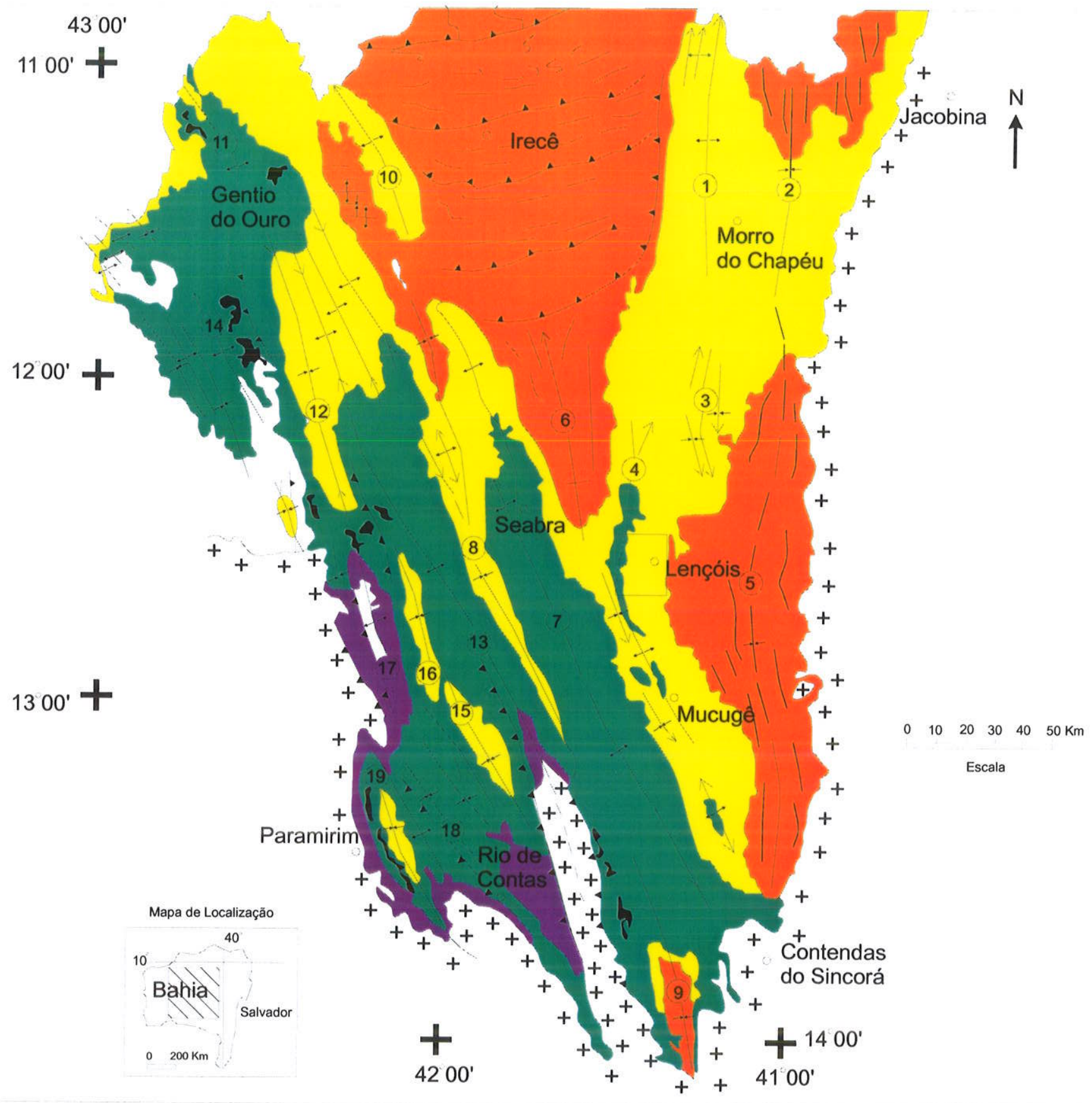

\section{LEGENDA}

1. Anticlinal de Morro do Chapéu

2 Sinclinal de Campinas

1 Anticlinal de Açuruá

12 Sinclinal de Mangabeira

3 Dobramentos da Região de Wagner

4 Anticlinal do Morro do Pai Inácio

13 Anticlinal da Cabrália

5 Sinclinal de Utinga

6 Sinclinal do Irecê

7 Anticlinal de Seabra

8 Sinclinal de Boninal

9 Sinclinal de Ituaçu

10 Anticlinal de Uibai

14 Anticlinal de Brotas

15 Sinclinal de Piatã

16 Sinclinal de Quitéria

17 Anticlinal de Ibitiara

18 Sinclinal de Rio das Contas

19 Sinclinal de Água Quente

\section{Área de estudo}

Cobertura Cenozóica

\section{Grupo Una}

Grupo Chapada Diamantina

ح Rocha Básica

- Grupo Paraguaçu

Grupo Rio dos Remédios

+ Embasamento pré-cristalino

Anticlinal

- Sinclinal

- Falha de empurrão

Cidade 
Figura III.4. Diagrama estratigráfico da Bacia do São Francisco (Medeiros \& Pereira 1994).

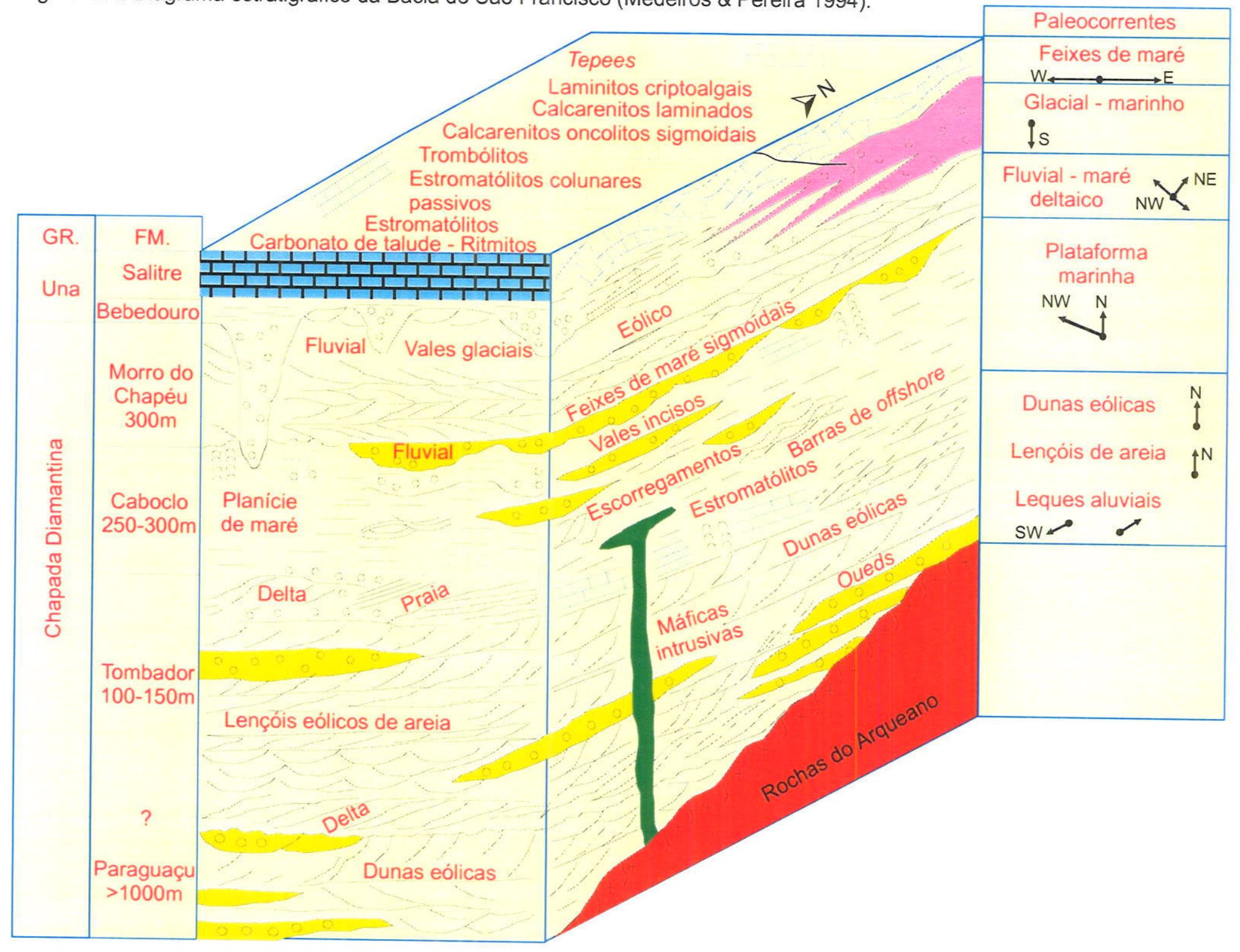


Tombador são encontrados conglomerados relacionados a leques aluviais, sotopostos a arenitos fluviais entrelaçados, com paleocorrentes para oeste. Durante os períodos secos, esses sedimentos eram retrabalhados pelo vento, formando lençóis de areia e campos de dunas. A transição para a Formação Caboclo se processa através depósitos deltaicos e de linhas de praia. A partir deste intervalo estratigráfico, os registros sedimentares das associações de litofácies que integram as formações Caboclo e Morro do Chapéu são condicionados pelas variações eustáticas do nível do mar. Ao final da deposição do Grupo Chapada Diamantina houve um grande hiato deposicional, durante o qual atuaram processos erosivos, caracterizando uma discordância no topo da unidade (Medeiros \& Pereira 1994).

Bonfim et al. (1996) mapearam cinco unidades litocronoestratigráficas ( 3 a 7 ) na Formação Tombador e uma unidade (8) na Formação Caboclo, na área do Parque Nacional da Chapada Diamantina (região de Lençóis). Segundo os autores, o ambiente evoluiu sucessivamente de fluvial entrelaçado/eólico (3) para eólico (4), fluvial entrelaçado (5), e leque aluvial/fluvial entrelaçado $(6,7)$, na Formação Tombador, e para planície de marés $(8)$, com a transgressão do mar Caboclo.

Pedreira (1994) agrupou os sistemas deposicionais pertencentes ao Supergrupo Espinhaço em quatro seqüências deposicionais na área da Chapada Diamantina Oriental. As duas inferiores coincidentes com os Grupos Rio dos Remédios e Paraguaçu; as duas superiores correspondentes às Formações Tombador-Caboclo e Morro do Chapéu. Esses sedimentos estão dobrados em um conjunto de anticlinais e sinclinais com eixos ondulados de direção NNW-SSE, cujo raio de curvatura aumenta de oeste para leste.

Sob o ponto de vista geotectônico Pedreira (1994) enquadra a Chapada Diamantina Oriental em um modelo de bacia foreland, devido às seguintes evidências: 1) sedimentação plataformal passando a marinha marginal; 2) deflexão da litosfera devido o peso das escamas de empurrão da faixa dobrada; 3) formação de uma antefossa; 4) preenchimento da antefossa por sedimentos provenientes da faixa dobrada; 5) existência de fácies misturadas e canibalísticas nos conglomerados do Membro Lavras indicativas de tectônica tangencial; 6) idades dos sedimentos plataformais semelhantes à idade da colisão; 7) depósitos minerais típicos de bacias foreland (urânio e vanádio no topo do Grupo Paraguaçu).

Rocha et al. (1996) estenderam o trabalho inicial de Medeiros \& Pereira (1994) à área de Jacobina-Morro do Chapéu, onde mapearam quatro associações de litofácies na Formação Tombador: leque aluvial, fluvial entrelaçado, eólico e transicional. As espessuras medidas para aquela formação variaram entre 100 e $140 \mathrm{~m}$, e, em uma seção estratigráfica, aqueles autores identificaram variação faciológica de fluvial para eólico, no sentido de sul para norte.

Pedreira (1997) individualizou doze diferentes litofácies para os sedimentos do Supergrupo Espinhaço que afloram na Chapada Diamantina centro-oriental. A sedimentação 
inicialmente é continental, representada por sistemas desértico e de leque aluvial e fluvial, com área fonte a oeste, que transicionam para um sistema deltaico. Sobre o sistema deltaico, após um evento tectônico que basculou a bacia, invertendo a direção das paleocorrentes, ocorrem novamente sistemas continentais e marinhos, provenientes de leste. A evolução tectônica pode ser seguida ao longo do tempo geológico pela alternância dos sistemas deposicionais e pela mudança no sentido das paleocorrentes como apresentado na figura Ill.5 (Pedreira 1997).

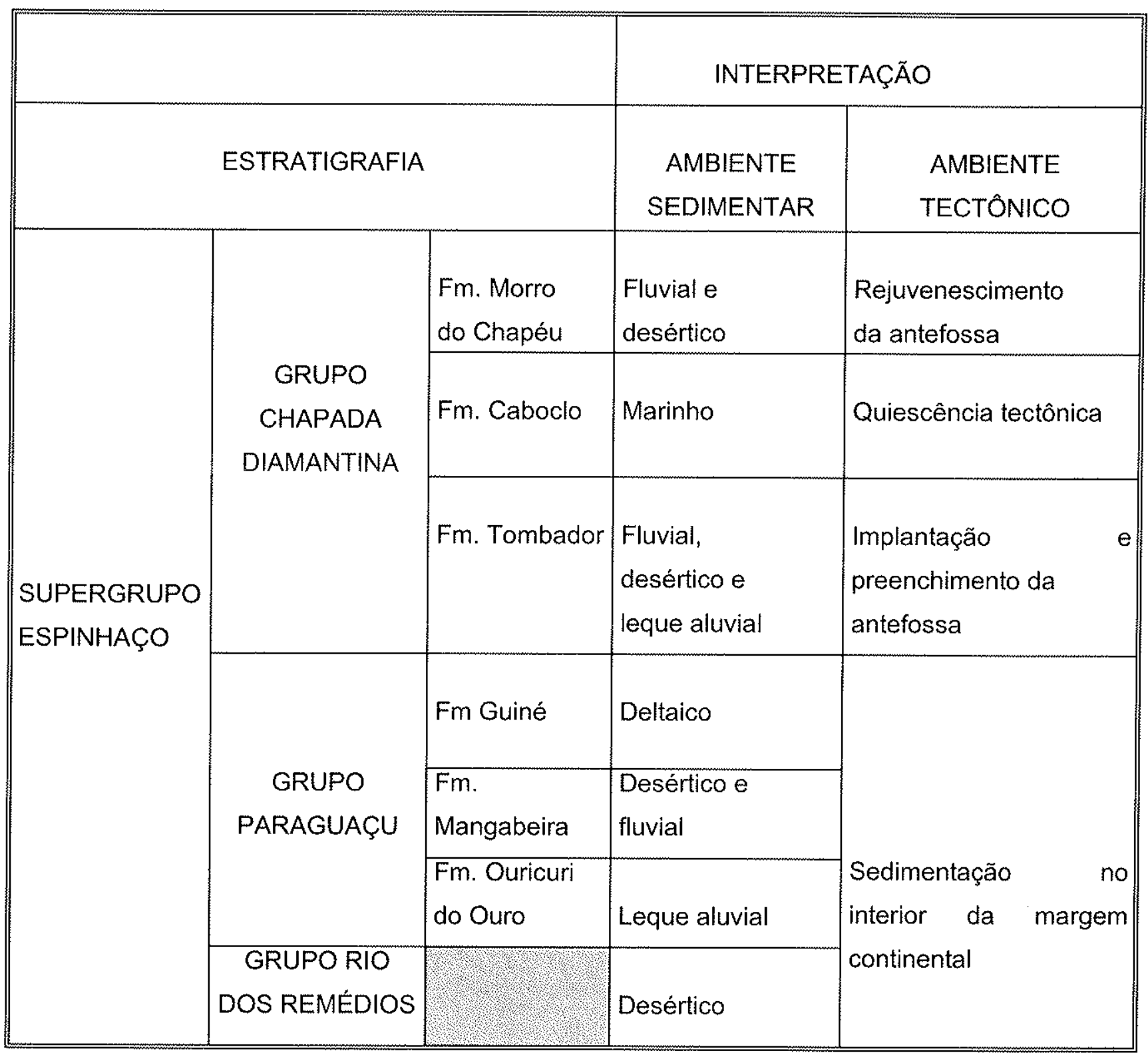

Figura III.5. Estratigrafia, sistemas deposicionais e tectônica do Supergrupo Espinhaço na Chapada Diamantina Centro-oriental (Pedreira 1997). 


\section{CAPÍTULO IV}

\section{ESTRATIGRAFIA DE SEQÜÊNCIAS}

\section{IV.I. REVISÃO DFOS CONCEITOS}

Estratigrafia de Seqüências é o estudo das relações das rochas dentro de um arcabouço cronoestratigráfico de estratos repetitivos e geneticamente relacionados, e que são limitados por superfícies de erosão ou não deposição ou por suas concordâncias correlativas (Van Wagoner et al. 1988). A unidade fundamental é a Seqüência, a qual é limitada por discordâncias e suas concordâncias correlativas. A Seqüência pode ser subdividida em tratos de sistemas, os quais são definidos por sua posição dentro da seqüência e pelos padrões de empilhamento de conjuntos de parasseqüências. Limites de seqüência, de conjunto de parasseqüências e de parasseqüências fornecem um arcabouço cronoestratigráfico para correlação e mapeamento de rochas sedimentares (Van Wagoner et al. 1988).

Os conceitos apresentados a seguir são importantes para o entendimento e a aplicação da Estratigrafia de Seqüências.

Parasseqüência é uma sucessão de estratos relacionados geneticamente ou conjunto de estratos limitados por superfícies de inundação marinha e suas superfícies correlativas (Van Wagoner et al. 1988).

Um conjunto de parasseqüências (Fig. IV.1) é uma sucessão de parasseqüências relacionadas geneticamente, o qual forma um modelo de empilhamento distinto limitado, em muitos casos, por superfícies de inundação marinha principais e suas superfícies correlativas (Van Wagoner et al. 1988). Os modelos de empilhamento de parasseqüências e conjuntos de parasseqüências são progradacional, retrogradacional e agradacional, dependendo da razão entre as taxas deposicionais e taxas de acomodação.

O espaço de acomodação é o espaço potencialmente disponivel para acumulação do sedimento, sendo função da subsidência tectônica e nível de base.

O nivel de base é considerado como uma superficie que separa presenvação de erosão, controlando conseqüentemente o espaço de acomodação.

Ocorrerá progradação da linha de costa quando a taxa de aporte sedimentar exceder a taxa de criação de espaço de acomodação. Quando as taxas de aporte sedimentar e criação de espaço de acomodação são balanceadas ocorrerá agradação. Se a taxa de aporte sedimentar for excedida pela de criação de espaço, ocorrerá então retrogradação. Onde o 
Figura IV.1. Conjuntos de parasseqüências (Van Wagoner et al. 1988).

Conjunto de Parasseqüências Progradacionais

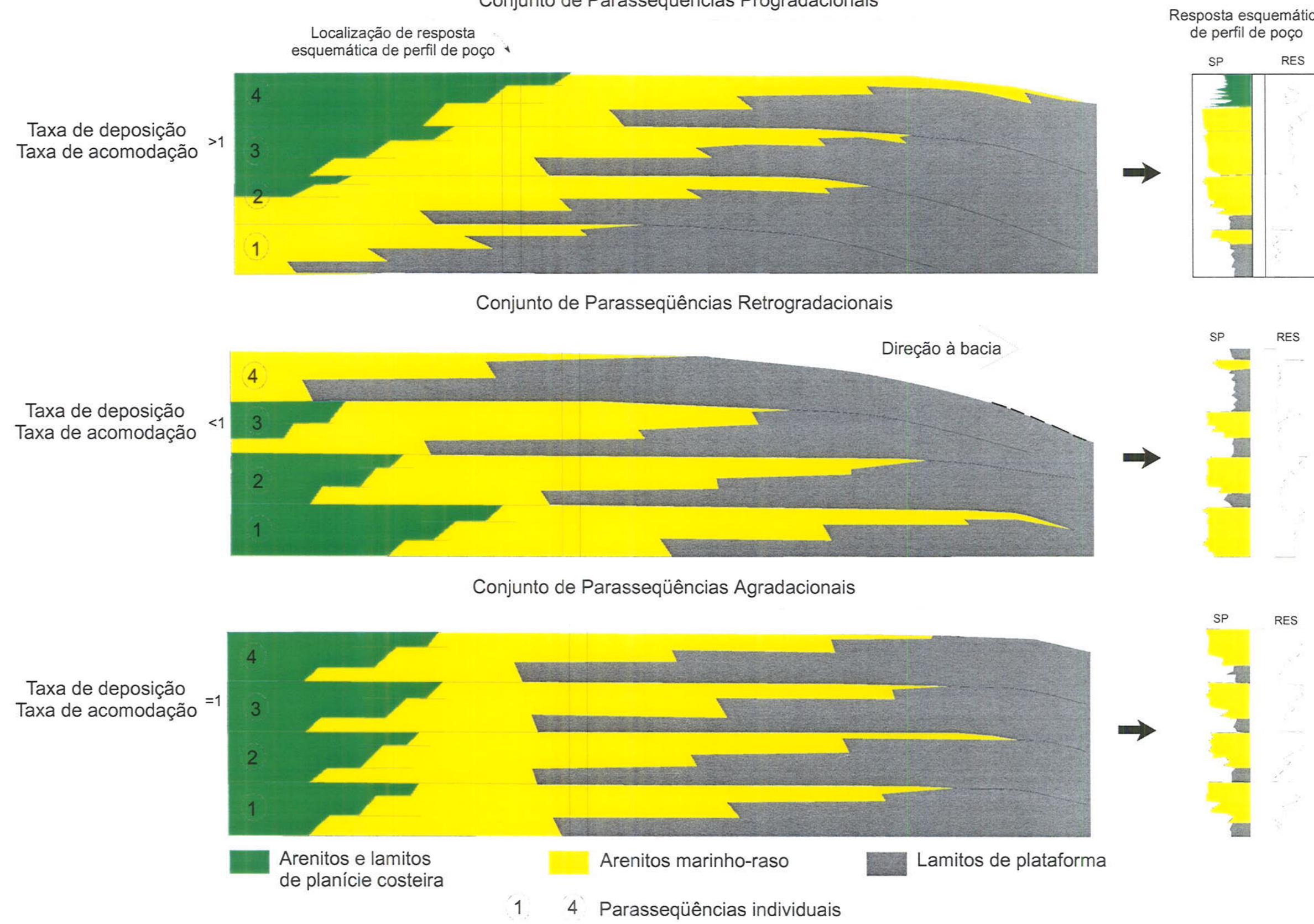


espaço de acomodação é zero há bypass sedimentar e onde o espaço é negativo acontecem erosão e incisão (Van Wagoner et al. 1988).

Seqüência é uma sucessão relativamente concordante de estratos relacionados geneticamente limitados por discordâncias e suas concordâncias correlativas (Mitchum 1977). As seqüências e seus componentes estratais formam-se em resposta à interação entre taxas de eustasia, subsidência e suprimento sedimentar.

A discordância é uma superficie que separa estratos mais jovens de estratos mais antigos, ao longo da qual há evidência de truncamento erosivo subaéreo (e, em algumas áreas, erosão submarina correlativa) ou exposição subaérea, indicando um significante hiato no registro sedimentar. A concordância é uma superfície estratal separando estratos mais jovens de estratos mais antigos, ao longo da qual não há evidência de erosão (tanto subaérea como submarina) ou não deposição e não há indicação de hiato.

Discordância do tipo 1 (ou limite de seqüência do tipo 1) seria caracterizada por deslocamento do onlap costeiro em direção à bacia, comumente abaixo da borda da plataforma, produzindo exposição subaérea da plataforma, incisão de vales e o início da formação de cânions na borda da plataforma. Seria caracterizada ainda por erosão subaérea e submarina e seria formada quando a taxa de queda eustática excedesse a taxa de subsidência na borda da plataforma.

Discordância do tipo 2 (ou limite de seqüência do tipo 2) seria caracterizada pelo deslocamento em direção à bacia do onlap costeiro, sem atingir a borda da plataforma e por não haver evidência de formação de cânions. Este tipo de discordância seria formado quando a taxa de queda eustática fosse menor que a taxa de subsidência na margem da plataforma, mas excedesse a taxa de subsidência na porção mais interna dela.

Um sistema deposicional é definido como uma assembléia tridimensional de fácies, geneticamente ligada por ambientes e processos ativos (modernos) ou inferidos (antigos) (Posamentier et al. 1988).

O trato de sistemas é a união de sistemas deposicionais contemporâneos (Brown \& Fisher 1977). Vail (1987) reconheceu a existência dos tratos de sistemas de mar baixo, transgressivo e mar alto numa seqüencia tipo 1 e tratos de sistemas de margem de plataforma, transgressivo e mar alto numa seqüência tipo 2.

O trato de sistemas de mar baixo, se depositado numa bacia com quebra de plataforma (Fig. IV.2), pode ser dividido em três unidades: leque de assoalho de bacia (basin-floor fan), leque de talude (slope fan) e cunha de mar baixo (lowstand wedge).

O leque de assoalho de bacia é caracterizado por deposição de leques submarinos no talude inferior no assoalho da bacia. A formação do leque está associada com à erosão dos cânions dentro do talude e a incisão de vales fluviais dentro da plataforma. Ocorre bypass de 
Figura IV.2. Modelos estratais numa seqüência do tipo 1 depositada numa bacia com quebra de plataforma (modificado de Van Wagoner, et al. 1988).

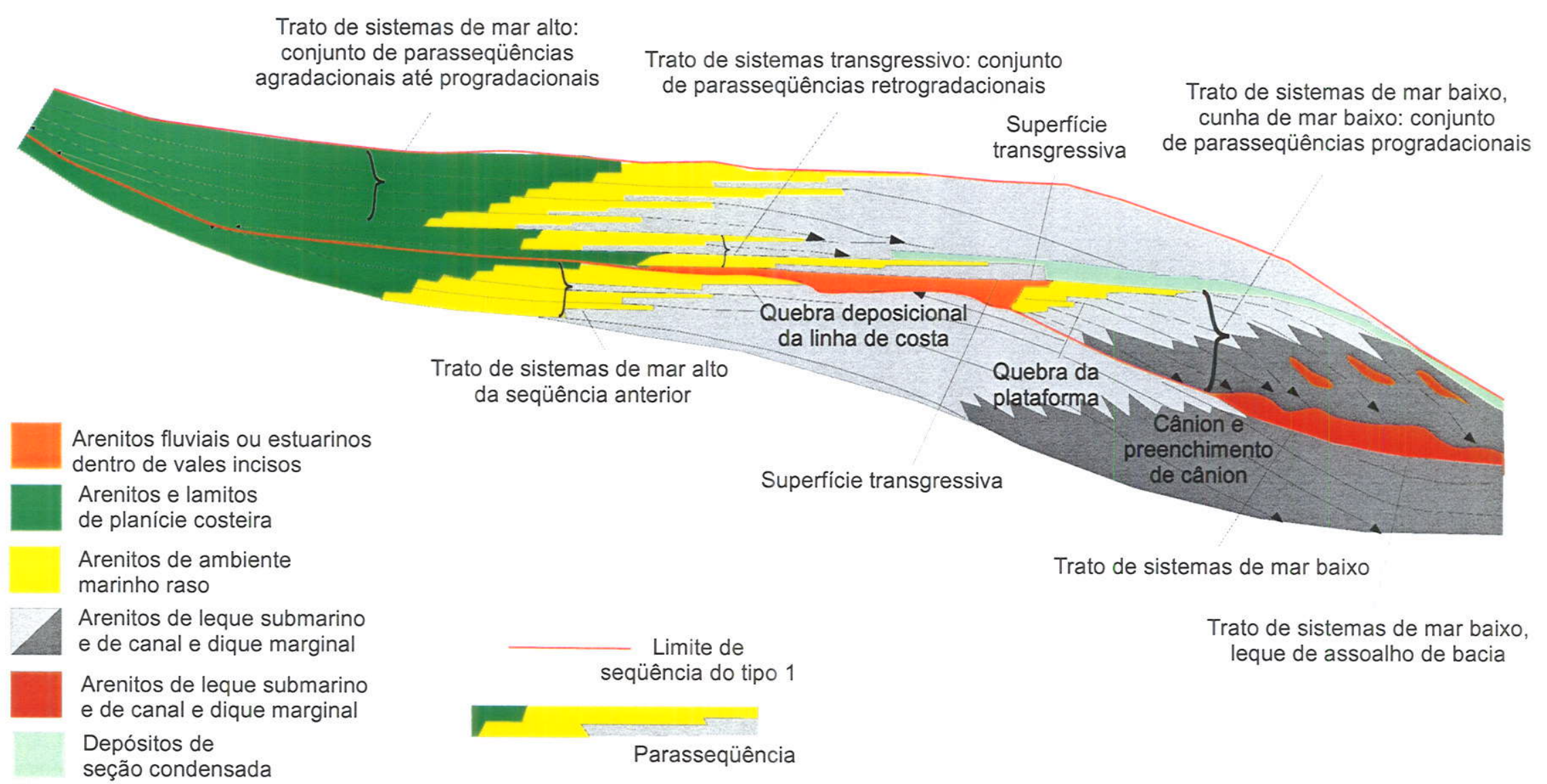


sedimentos siliciclásticos na plataforma e no talude através de vales e cânions para alimentar o leque de assoalho de bacia durante queda relativa do nivel do mar (Van Wagoner et al. 1988).

O leque de talude é caracterizado pela deposição de fluxo de detritos e turbiditos no meio ou na base do talude. Esta deposição pode ser contemporânea com o leque de assoalho de bacia ou com a porção inicial da cunha de mar baixo.

A cunha de mar baixo é caracterizada na plataforma pelo preenchimento de vales incisos. Ela não é contemporânea com a deposição de sedimentos do trato de sistemas de assoalho de bacia. As cunhas de mar baixo são compostas por conjuntos de parasseqüências progradacional e agradacional.

O trato de sistemas de mar baixo, se depositado em uma bacia tipo rampa (Fig. N.3), consiste de uma cunha de mar baixo relativamente delgada contendo duas partes. A primeira é caracterizada por incisão de correntes e bypass de sedimentos da planície costeira. A segunda parte da cunha é caracterizada por lenta elevação do nível do mar, preenchimento de vales incisos, e contínua progradação da linha de costa. O topo da cunha de mar baixo é uma superficie transgressiva e a base é um limite de seqüência inferior.

Qualquer oscilação do nível de base em uma bacia do tipo rampa, com sistemas deposicionais costeiros, implica na variação da criação ou perda de espaço de acomodação e portanto, influencia diretamente o padrão de empilhamento vertical das fácies (Shanley \& McCabe 1994).

O trato de sistemas de margem de plataforma (Fig. N.4) é o trato de sistemas mais inferior associado a um limite de seqüência do tipo 2. Este trato de sistemas é caracterizado por um ou mais conjunto de parasseqüências fracamente progradacional e agradacional. $O$ topo do trato de sistemas de margem de plataforma é uma superfície transgressiva, a qual também forma a base do trato de sistemas transgressivo, enquanto a base é um limite de seqüência do tipo 2 .

O trato de sistemas transgressivo é o trato de sistemas intermediário tanto na seqüência do tipo 1 como na do tipo 2. É marcado por um ou mais conjuntos de parasseqüências retrogradacionais. A base do trato de sistemas transgressivo é uma superfície transgressiva posicionada também no topo do trato de sistemas de mar baixo ou de margem de plataforma. O topo do trato de sistemas transgressivo é uma superfície de downlap representando uma superfície marinha de inundação. Esta superfície marca a mudança de um conjunto de parasseqüências retrogradacionais até agradacionais e é também denominada de superfície de inundação máxima.

A seção condensada (Figs. IV.2 e IV.3) ocorre amplamente dentro dos tratos de sistemas transgressivo e de mar alto distal. Trata-se de uma fácies de delgadas camadas marinhas de sedimentos hemipelágicos e pelágicos. 
Figura IV.3. Modelos estratais numa seqüência do tipo 1 depositada numa bacia tipo rampa (modificado de Van Wagoner et al. 1988).

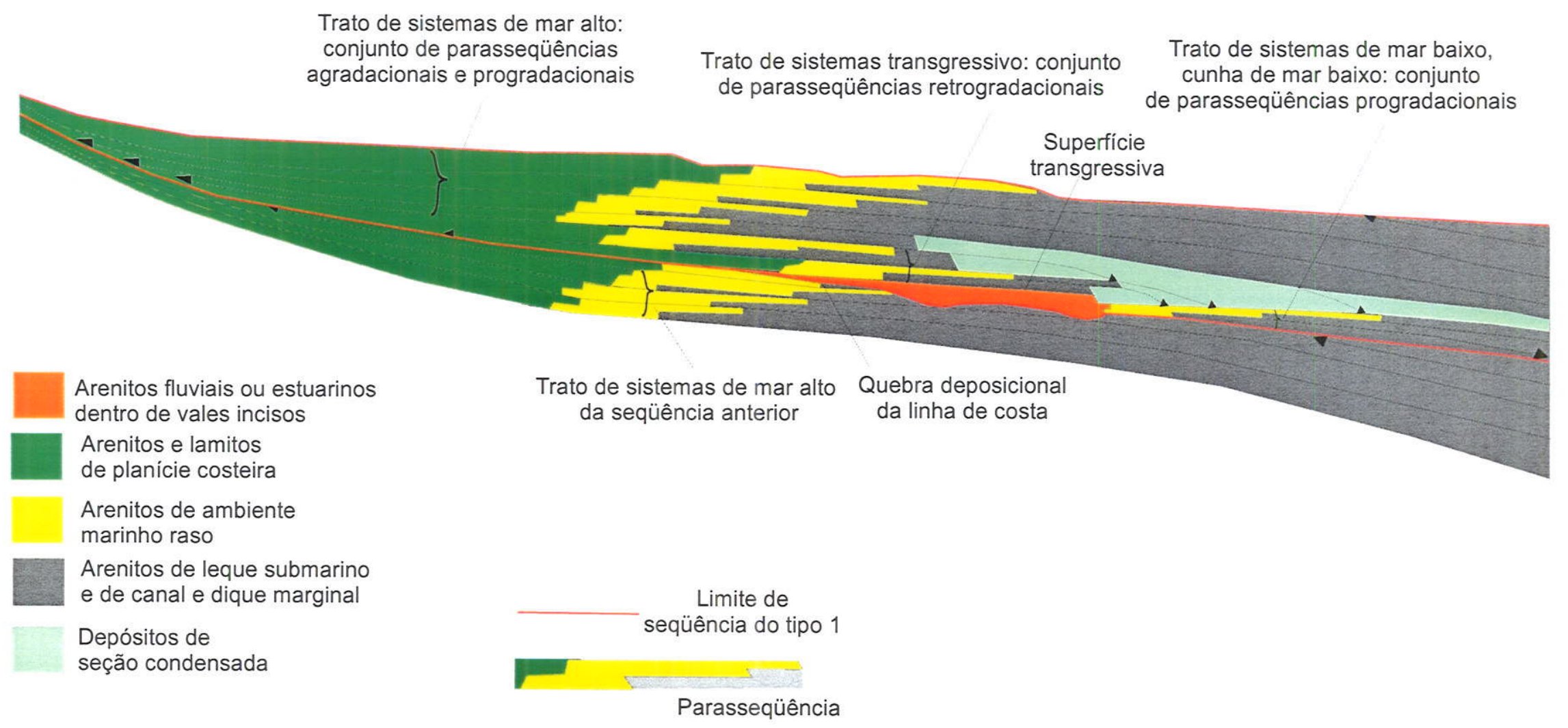


Figura IV.4. Modelos estratais numa seqüência do tipo 2 (modificado de Van Wagoner et al. 1988).

Trato de sistemas de mar alto: conjunto de parasseqüências até progradacionais

s

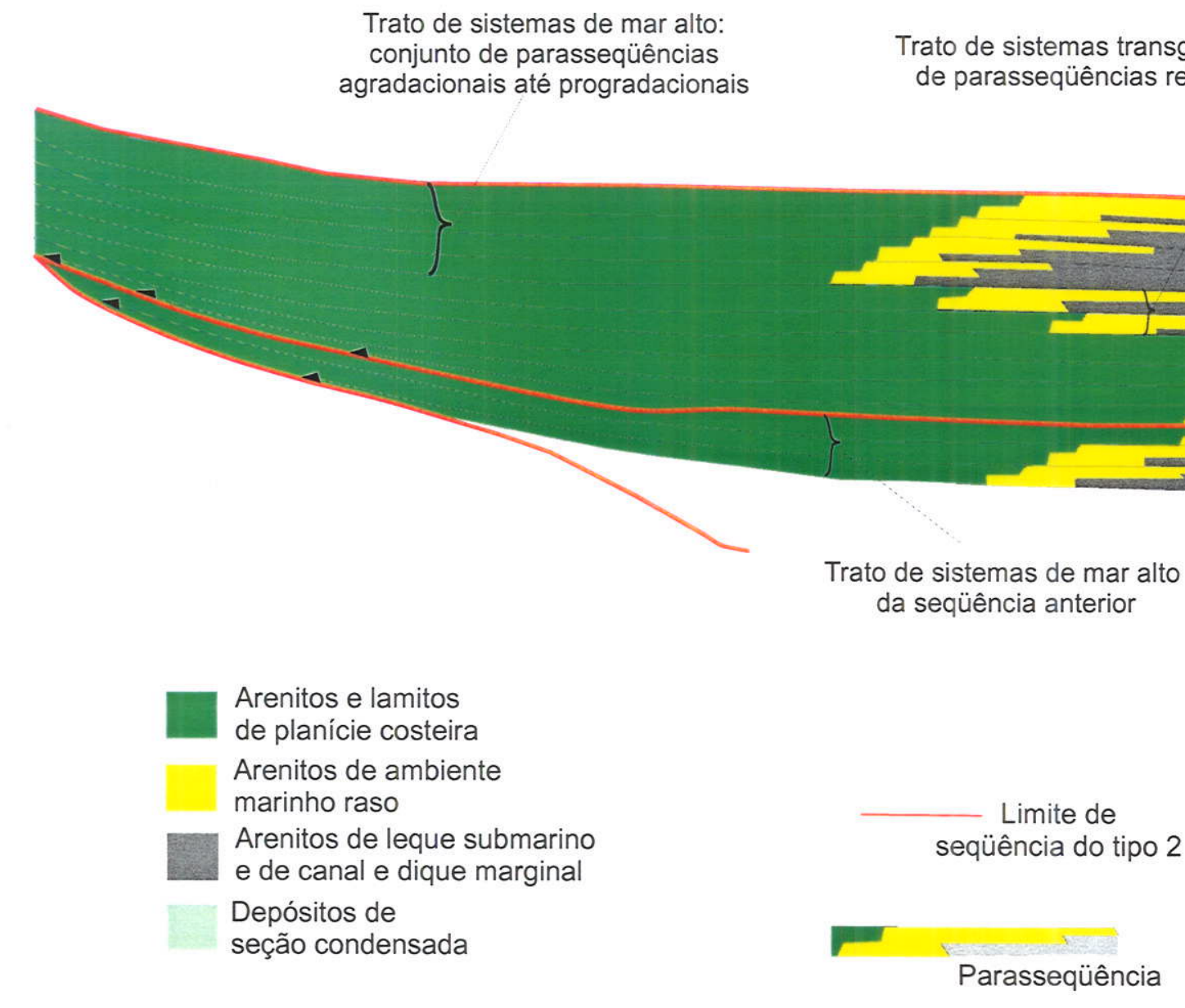

Trato de sistemas transgressivo: conjunto de parasseqüências retrogradacionais
Trato de sistemas de margem de plataforma: conjunto de parasseqüências progradacionais até agradacionais 
O trato de sistemas de mar alto (Figs. IV.2, IV.3 e IV.4) é o trato superior tanto numa seqüência do tipo 1 como do tipo 2. Este trato de sistemas é comum na plataforma e pode ser caracterizado por um ou mais conjuntos de parasseqüências agradacionais que são sucedidos por um ou mais conjuntos de parasseqüências progradacionais. O trato de sistemas de mar alto é limitado no topo por limites de seqüências dos tipos 1 ou 2 e na base por uma superficie de downlap.

\section{SEQÜÊENCIAS GENËTICAS DE GALL_OWAY}

Galloway (1989) reconheceu que as margens das bacias marinhas são caracterizadas por episódios repetitivos de progradação, pontuados por periodos de transgressão e inundação da plataforma, introduzindo assim, para as unidades estratigráficas resultantes, o termo seqüência estratigráfica genética. Uma seqüência estratigráfica genética é o produto sedimentar de um episódio deposicional, limitada por superfícies de inundação.

Existe algumas diferenças entre a estratigrafia de seqüências deposicionais do grupo da Exxon (Vail, Posamentier, Van Wagoner, entre outros) e a estratigrafia de seqüências genéticas de Galloway (Fig. IV.5). O grupo da Exxon usa essencialmente dados sísmicos, enquanto que Galloway enfatiza a sedimentologia, interpretando ambientes pelas feições internas e geometria de fácies. Galloway (1989) não reconhece a eustasia como mecanismo principal de evolução estratigráfica, preferindo utilizar tectonismo/subsidência. Enquanto que as seqüências deposicionais são centradas nos eventos de inundação marinha, as seqüências estratigráficas genéticas de Galloway são limitadas por eles.

Na geologia, o termo seqüência é caracterizado por continuidade. Em uma sucessão estratigráfica, pontuada por discordâncias e seções condensadas, as quebras mais importantes e significativas (ex. geral: quebras temporal, estratigráfica, deposicional, etc) são representadas pelas discordâncias. A seção condensada é meramente uma litofácies fina, a qual faz parte de uma "deposição contínua" entre os sedimentos sotopostos e sobrepostos (Posamentier \& James 1993).

Será adotado na tese de doutorado o modelo do grupo da Exxon, admitindo que a eustasia é o principal fator que governa a deposição dentro da Estratigrafia de Seqüências, e que as quedas do nível do mar são mais apropriadas para se definir os limites das seqüências, ao contrário dos eventos de inundação. 
Figura IV.5. Comparação entre a posição do limite na "seqüência deposicional" do grupo da Exxon com o limite na "seqüência estratigráfica genética" de Galloway. A seqüência do tipo 1 e B seqüência do tipo 2 (Miall 1997).

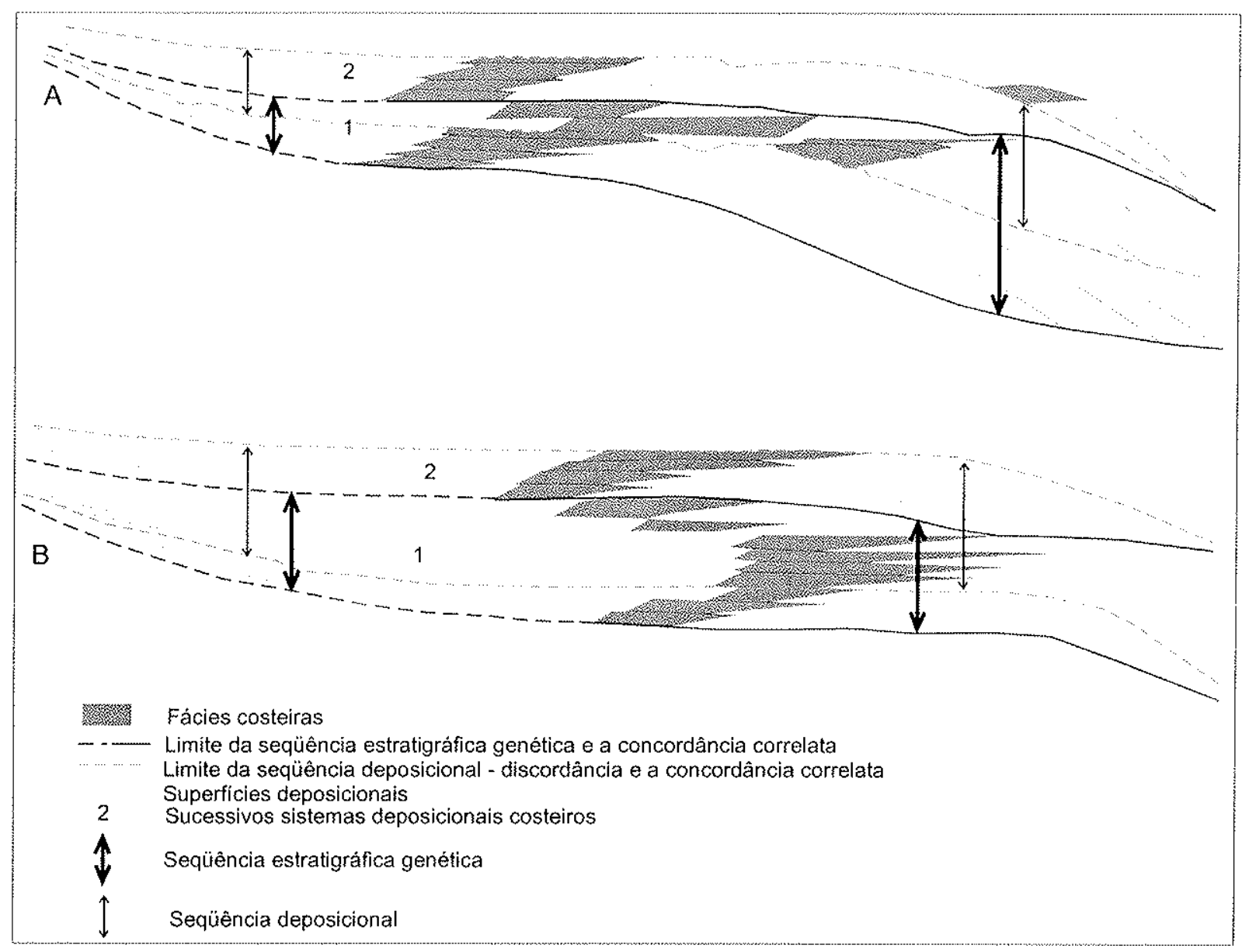




\section{IV.II. ESTRATTIGRAFIA DE SEQÜÊNCIAS NO PROTTEROZÓICO}

A Estratigrafia de Seqüências é o estudo de mudanças de fácies dentro de um arcabouço de tempo. Para sua interpretação são necessários os controles das fácies e do tempo. As fácies são obtidas através de análises sedimentológica e de fácies, e o tempo, requer pesquisas por métodos independentes, tais como bioestratigrafia, datação radiométrica e magnetoestratigrafia (Catuneanu \& Erikssom 1999).

A aplicação da análise de Estratigrafia de Seqüências no Pré-cambriano é extremamente difícil, pois a análise de fácies e a reconstrução paleoambiental dos sistemas deposicionais são limitadas pela pobre preservação, tectônica pós-deposicional, transformações diagenéticas e metamorfismo. As idades das rochas precambrianas são baseadas em datações radiométricas, sendo mais imprecisas que as de seqüencias mais jovens, e com margens de erro de pelo menos $1 \mathrm{Ma}$. Por isso, é quase impossivel correlacionar seqüências de alta resolução, com duração menor que $10^{0}-10^{1} \mathrm{Ma}$ (Catuneanu \& Erikssom 1999).

É também importante lembrar as diferenças existentes entre os sistemas deposicionais do Pré-cambriano e do Fanerozóico. Primeiramente, a ausência de vegetação teve efeitos profundos em muitos sistemas deposicionais do Pré-cambriano. Nos depósitos deltaicos há ausência de plantas e fósseis vertebrados. Os sistemas de canais, devido a ausência de vegetação, foram certamente do tipo braided. As espessuras das seqüências deltaicas são maiores que as atuais, atribuídas a contextos tectônicos mais ativos. Sedimentos de plataforma e shoreface sugerem a possibilidade de sistemas marinho rasos com circulação mais uniforme. As plataformas eram amplas com taludes suaves, em contraste com plataformas atuais, estreitas e íngremes. A influência das marés está em muitos registros, provavelmente devido a maior proximidade da Terra e da Lua, etc (Eriksson et al. 1998).

O reconhecimento dos limites de seqüências é fundamental para se confiar na interpretação da seqüência estratigráfica. No Pré-cambriano isso não é tão fácil, devido à pobre resolução bioestratigráfica, e à dificuldade de se observar as evidências estratigráficas físicas das quebras, comumente desenvolvidas localmente. Os critérios utilizados para a identificação dos limites de seqüência são: (a) evidência de exposição subaérea e/ou erosão (vales incisos), (b) mudanças abruptas de fácies, e (c) mudança no modelo de estaqueamento das parasseqüências. No Proterozóico, a maioria dos vales incisos, os quais são preenchidos por uma combinação de depósitos fluviais e estuarinos, apresentam depósitos grossos distintos dos estratos abaixo, marcando bem o limite (Christie Blick et al. 1995). 
As seções estratigráficas mais espessas (maior que $5 \mathrm{~km}$ no Proterozóico) são melhores para se observar um maior número de seqüências. Em seções pouco espessas, superfícies de descontinuidade tendem a produzir quebras amalgamadas. A abundância de limites de seqüência em espessas sucessões do Proterozóico reflete antes uma melhor preservação dos eventos geológicos do que a ausência deles (Christie Blick et al. 1995).

A maioria dos depósitos neoproterozóicos acumularam-se em contextos de margem passiva, intracratônico (Bacia Amadeus, Austrália, Lindsay 1987), antepaís e extensional, caracterizados por rampas rasas sem quebras pronunciadas no talude. Depósitos de água profunda ( Neoproterozóico da América do Norte e Austrália, porém constituem exceções (Christie Blick et al. 1995).

O Supergupo Transvaal (2.7-2.1Ga - África do Sul) foi reconhecido como uma seqüência deposicional de $1^{\text {a }}$ ordem sendo limitado por contatos discordantes que marcam mudanças principais nos trends geodinâmicos do Cráton Kaapvaal. Foram identificadas quatro discordâncias subaéreas dentro da sucessão Transvaal, subdividindo a seqüência de $1^{a}$ ordem em cinco seqüências deposicionais de $2^{\mathrm{a}}$ ordem com duração de $130 \mathrm{Ma}$. Elas apresentam duração maior que os ciclos de $2^{\mathrm{a}}$ ordem do Fanerozóico devido à menor velocidade de movimentação das placas tectônicas ao final do Arqueano e início do Proterozóico (Catuneanu \& Erikssom 1999).

O Neoproterozóico da Bacia de Amadeus (Austrália) é representado pelo Arenito Arumbera. Foram reconhecidas duas seqüências deposicionais neste intervalo. Durante a deposição da primeira seqüência, quando o nivel do mar atingiu o seu máximo, a sedimentação foi amplamente gradacional, com pequenos deltas progradando sobre uma plataforma carbonática (Formação Julie sotoposta). Durante a acumulação da segunda seqüência, o nivel do mar caiu rapidamente expondo amplas áreas de sedimentos depositados durante o primeiro ciclo e restringindo a sedimentação (deltas) a duas porções mais profundas. Os principais fatores controladores na deposição foram: subsidência, tectonismo, ciclos do nível do mar, clima e biosfera. Este último, diferente da biosfera atual devido à ausência de plantas, deposição de carbonatos nas áreas interdistributários, ao invés de carvão. Esta similaridade sugere que prevaleceram condições mais alcalinas do que ácidas nesses ambientes de água rasa ao final do Proterozóico (Lindsay 1987).

Com relação ao Grupo Chapada Diamantina, Dominguez (1992) reconheceu duas seqüências deposicionais: (1) Tombador-Caboclo e (2) Morro do Chapéu. No presente trabalho constatou-se que há pelo menos seis seqüências deposicionais apenas na Formação Tombador, indicando que a medida em que se faz um estudo de campo detalhado é possivel reconhecer seqüências de ordem cada vez menor em depósitos do Pré-cambriano. 


\section{CAPÍTULOV}

\section{FÂCIES E ASSOCIAÇÕES FACIOLÓGICAS}

$\mathrm{Na}$ área em estudo, o metamorfismo e a deformação foram incipientes. As estruturas sedimentares estão bem preservadas, porém a cimentação foi intensa, caracterizada pela forte presença de sobrecrescimento de quartzo na maioria das lâminas estudadas. Devido essa intensa cimentação, muitas vezes é difícil o reconhecimento da granulometria das rochas nos afloramentos.

A partir de um detalhado estudo de campo foram reconhecidas 20 fácies sedimentares na Formação Tombador. Cada fácies foi caracterizada por uma ou duas letras iniciais em maiúsculo indicando a litologia, seguida de uma ou duas letras em minúsculo indicando a estrutura sedimentar presente. As fácies encontram-se listadas abaixo:

- C Conglomerado

- B Brecha

- BA Brecha e arenito

- ACa Arenito conglomerático com estratificação cruzada acanalada

- Aa Arenito com estratificação cruzada acanalada

- At Arenito com estratificação cruzada tabular

- Att Arenito com estratificação cruzada tabular tangencial

- Atd Arenito com estratificação cruzada tabular e drape de folhelho

- Ahb Arenito com estratificação cruzada espinha-de-peixe (herringbone)

- Ap Arenito com laminação horizontal

- As Arenito com estratificação cruzada sigmóide

- Ar Arenito com laminação cruzada clino-ascendente (ripple drift cross-lamination)

- Ah Arenito com estratificação ondulada truncante (hummocky)

- Asw Arenito com estratificação cruzada swaley

- Ao Arenito com laminação cruzada por onda e flaser

- Aba Arenito com estratificação cruzada de baixo ângulo

- R Ritmito arenito/siltito

- Rc Ritmito arenito/siltito com carga

- Iw Interlaminado arenito/siltito (wavy)

- S Siltito

As fácies sedimentares foram agrupadas em 16 associações faciológicas, apresentadas no quadro a seguir: 


\begin{tabular}{|c|c|c|}
\hline Associação/Ambiente & Fácies/Descrição & Figura \\
\hline \multirow[t]{2}{*}{ Leque aluvial } & Conglomerado & V.1 \\
\hline & Brecha & V.2 \\
\hline $\begin{array}{l}\text { Leque subaquoso } \\
\text { (Rio Capivara) }\end{array}$ & Estratos com brecha gradando a arenito & V.3 \\
\hline $\begin{array}{l}\text { Fan delta estuarino } \\
\text { (Rio Mucugezinho-BR242) }\end{array}$ & $\begin{array}{l}\text { Progradação: conglomerado sobre arenito/siltito e sobre siltito } \\
\text { Retrogradação: conglomerado sob arenito/siltito e sob siltito }\end{array}$ & V.4 \\
\hline $\begin{array}{l}\text { Fluvial torrencial } \\
\text { (Rio Mucugezinho) }\end{array}$ & $\begin{array}{l}\text { Arenito grosso a conglomerado com estratificação cruzada e } \\
\text { laminação horizontal }\end{array}$ & V.5 \\
\hline $\begin{array}{l}\text { Fluvial } \\
\text { (Rio Ribeirão) }\end{array}$ & $\begin{array}{l}\text { Arenito gradando a conglomerado com estratificação cruzada } \\
\text { acanalada }\end{array}$ & V.6 \\
\hline $\begin{array}{l}\text { Fluvial costeira } \\
\text { (Rio Mucugezinho-BR242 } \\
\text { "placa portal") }\end{array}$ & $\begin{array}{l}\text { Arenito espesso com estratificação cruzada, laminações } \\
\text { horizontal e cruzada, e flaser }\end{array}$ & V.7 \\
\hline $\begin{array}{l}\text { Eólica } \\
\text { (Rio Mucugezinho) }\end{array}$ & $\begin{array}{l}\text { Arenito com laminação horizontal e estratificação cruzada tabular } \\
\text { tangencial }\end{array}$ & V.8 \\
\hline Litorânea/praia & Arenito com laminação horizontal e marcas de onda (crista reta) & V.9 \\
\hline $\begin{array}{l}\text { Deltaica tipo Gilbert } \\
\text { (Rio Mucugezinho-BR242) }\end{array}$ & $\begin{array}{l}\begin{array}{l}\text { Progradação de topsets e foresets de arenito sobre siltito } \\
\text { (Marinho) }\end{array} \\
\end{array}$ & V.10 \\
\hline $\begin{array}{l}\text { Frente deltaica } \\
\text { (Rio Capivara) }\end{array}$ & $\begin{array}{l}\text { Arenito com laminações horizontal e cruzada, e estrutura de } \\
\text { carga (load-ripple) }\end{array}$ & V.11 \\
\hline $\begin{array}{l}\text { Planície deltaica/ marinha } \\
\text { (Rio Ribeirão de Baixo) }\end{array}$ & $\begin{array}{l}\text { Progradação: arenito grosso e conglomerado (planície } \\
\text { deltaica/fluvial) sobre arenito e siltito (marinho) }\end{array}$ & V.12 \\
\hline $\begin{array}{l}\text { Marinha/frente deltaica (Rio } \\
\text { Ribeirão de Baixo) }\end{array}$ & $\begin{array}{l}\text { Siltito/ritmito marinho sob arenito grosso com estratificação } \\
\text { cruzada tabular }\end{array}$ & V.13 \\
\hline \multirow{2}{*}{$\begin{array}{l}\text { Estuarina/marinha } \\
\text { (Rio Ribeirão de Cima) } \\
\text { (Rio Mucugezinho-BR242 } \\
\text { "ponte") }\end{array}$} & $\begin{array}{l}\text { Canal de arenito com estratificação cruzada sigmóide gradando } \\
\text { a arenito/siltito com estratificação hummocky (tempestito) }\end{array}$ & V.14 \\
\hline & $\begin{array}{l}\text { Canais preenchidos por arenito com estratificação sigmóide } \\
\text { intercalados com ritmitos e arenitos com estratificação acanalada }\end{array}$ & V.15 \\
\hline \multirow{2}{*}{$\begin{array}{l}\text { Estuarina distal/marinha } \\
\text { (Rio Mucugezinho-BR242 } \\
\text { "mengão") } \\
\text { (Alto do Morro do Pai Inácio) }\end{array}$} & $\begin{array}{l}\text { Intercalações de arenito (estratificação cruzada acanalada e } \\
\text { sigmóide, geometria tabular) e siltito }\end{array}$ & V.16 \\
\hline & Arenito sigmoidal intercalado com siltito (marinho) & V.17 \\
\hline $\begin{array}{l}\text { Deltaica/marinha (barra de } \\
\text { marés) } \\
\text { (Morro do Pai Inácio -face } \\
\text { sul) }\end{array}$ & $\begin{array}{l}\text { Progradação: siltito sob arenito com estratos delgados e } \\
\text { bifurcantes sob arenito com estratificação sigmóide (barra de } \\
\text { Marés) }\end{array}$ & V.18 \\
\hline \multirow{4}{*}{$\begin{array}{l}\text { Marinha shoreface } \\
\text { (Rio Capivara) } \\
\text { (Rio Lapão) }\end{array}$} & $\begin{array}{l}\text { Arenito com estratificação ondulada truncante hummocky, estrat. } \\
\text { microhummocky, e interlaminação wavy e siltito (tempestito) }\end{array}$ & V.19 \\
\hline & Tempestito e brecha intraformacional & V.20 \\
\hline & Tempestito e brecha intraformacional & V.21 \\
\hline & Tempestito com estratificação convoluta & V.22 \\
\hline
\end{tabular}


Legenda das associações faciológicasdos, perfis estratigráficos e seções estratigráficas.

Fácies Sedimentares

D-Siltito

$R$ - Ritmito arenito/folhelho

Rc - Ritmito arenito/folhelho com sobrecarga

玉 I - Interlaminado arenito e folhelho (wavy)

A Ao-Aren. c/lamin. por onda

$\rightarrow$ Ar - Aren. c/ lamin. cruz. clino-ascendente (ripple drift)

Ap - Aren. c/ lam. plano horizontal

Ahb - Aren. c/ estrat. cruz. espinha-de-peixe (herringbone)

At - Aren. c/ estrat. cruz. Tabular

$\Theta$ Atd - Aren. com tidal bundle

Ea Aa - Aren. c/ estrat. cruz. acanalada

은 A - Aren, c/ estrat. Cruzada hummocky

Ahc - Aren. c/ estrat. cruzada hummocky e convoluta

$A b-$ Arenito com brecha

2 Att - Aren. c/ estrat. cruz. tabular tangencial

$\otimes$ As - Aren. c/ estrat. cruz. sigmóide

x $\mathrm{ACa}$ - Aren. conglomerático c/ estrat. cruz. acanalada

D C - Conglomerado

B - Brecha

Estruturas e Litologias

$\nabla$ Greta

(V) Marca de carga

- Clasto de argila

스 Wavy

$\Leftrightarrow$ Linsen

Flaser

Bioturbação

Laminação cruzada clino-ascendente (ripple drift)

$\Longrightarrow$ Lam. plano horizontal

^ Estrat. cruz. de baixo ângulo

MIV Estrat. cruz. tabular

$\Leftrightarrow \rightarrow$ Estrat. cruz. espinha-de-peixe (herringbone)

Estrat. cruz. ondulada truncante (hummocky)

Estrat. cruz. tabular tangencial

Estrat. cruz. acanalada

(\$) Estrat. cruz. Sigmóide

Estrat. convoluta

Interlaminado aren./folhelho

0 Seixo

a - argila

$s$ - silte

amf - areia muito fina

af - areia fina

am - areia média

ag - areia grossa

amg - areia muito grossa

c - conglomerado

8 Brecha

oD Matacão 


\section{LEQUE ALUVIAL}

\section{(a) Fácies Conglomerado}

A associação de leque aluvial é constituída predominantemente pela fácies conglomerado $\mathrm{C}$, com espessura que normalmente alcançam $20 \mathrm{~m}$ (Fig. V.1-A), e também com ampla extensão lateral. A associação faciológica é característica do intervalo superior da Formação Tombador. Localmente se observa uma geometria de canal, com um relevo superior a $10 \mathrm{~m}$, como na Gruta do Lapão (ponto La-8); os conglomerados apoiam-se erosivamente sobre arenitos de natureza eólica ou fluvial (Fig. V.1-B).

Os conglomerados são constituídos predominantemente de seixos e calhaus, geralmente com 3 a 15 centímetros, de quartzito leitoso róseo e verde, apresentando-se subesféricos a elipsoidais, e arredondados (Figs. V.1-D, V.1-F).

Comumente o conglomerado intercala-se com estratos de 0,3 a $1,0 \mathrm{~m}$ de espessura de arenito médio com estratificação cruzada acanalada (Figs. V.1-C, V.1-D). Nota-se também, ocasionalmente imbricação dos seixos (Fig. V.1-F) e/ou estratificação cruzada com sentido de fluxo para oeste a noroeste (Fig V.1-E).

A fácies conglomerado $\mathbf{C}$ está relacionada a rios entrelaçados cascalhentos formados em sistemas de leque aluvial (Collinson 1996). É comum a presença de grandes clastos arredondados e de baixa esfericidade na base do conglomerado, como observado na cachoeira do Grisante (um afluente do Rio Lençóis): estes clastos são originados da erosão e retrabalhamento fluvial de depósitos eólicos sotopostos. Também é marcante a associação com brechas, no último ciclo do intervalo superior da Formação Tombador.

A Serra de Jacobina deve ter servido como área fonte desses conglomerados devido à presença de quartzito verde (Pedreira 1988).

\section{(b) Fácies Brecha}

A associação de leque aluvial também compreende brechas, fácies $\mathbf{B}$, apresentando-se como uma massa caótica composta de calhaus e matacões de quartzito, prismáticos, angulosos, com 0,2 a $1 \mathrm{~m}$ de comprimento (Fig. V.2-A), junto com clastos decimétricos subarredondados de quartzito e arenito (Fig. V.2-B). Está bem representada nos perfis dos rios Mucugezinho, Ribeirão de Baixo (e seu afluente Córrego da Onça) e Capivara, no último ciclo do intervalo superior da Formação Tombador (pontos Mu34/35, Ri3 e Ca2).

Ocasionalmente observa-se imbricação dos matacões com sentido de fluxo para oeste, e afinamento textural para o topo (Figs. V.2-B, V.2-D). Aparece apenas na parte mais superior da Formação Tombador, estando normalmente associada a conglomerados; neste caso se 
Figura V.1. Associação de leque aluvial (Fácies conglomerado).
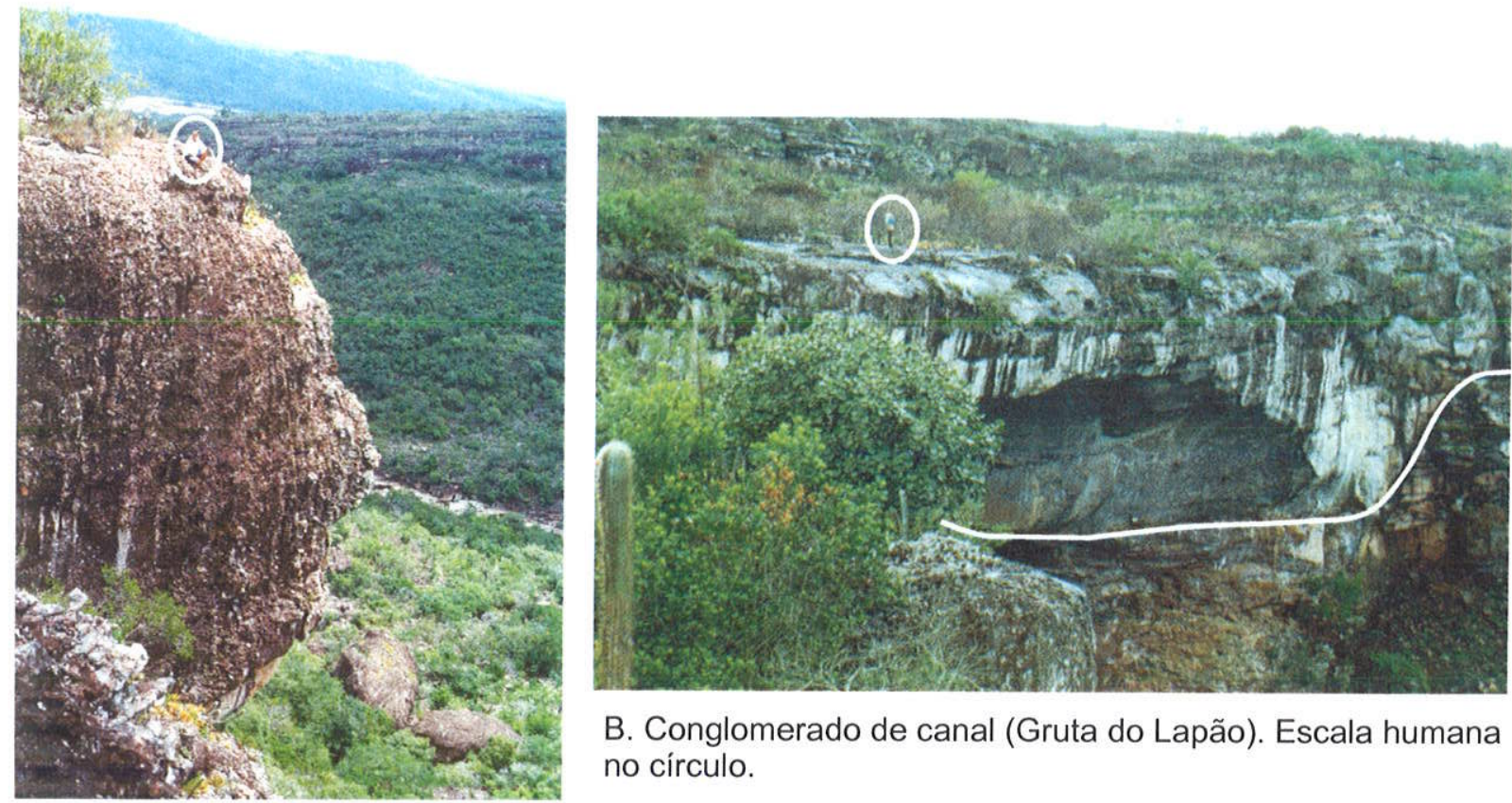

B. Conglomerado de canal (Gruta do Lapão). Escala humana no círculo.

A. Fácies conglomerado com $20 \mathrm{~m}$ de espessura (Córrego da Onça). Escala humana no círculo.
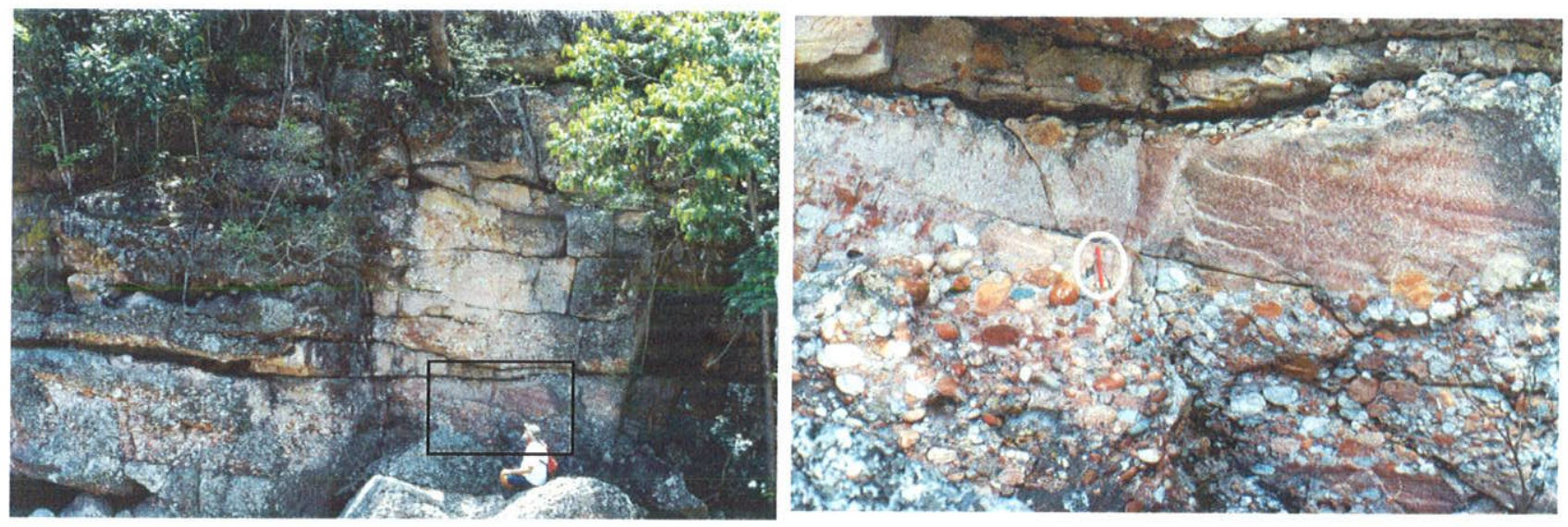

C. Estratos de conglomerado e arenito médio com D. Conglomerado contendo clastos $(1 \mathrm{a} 8 \mathrm{~cm})$ de quarestratificação cruzada acanalada (Rio Lençóis). O tzito rosa-avermelhado e leitoso, intercalado com areretângulo indica um detalhe da foto seguinte.

nito. A escala nas fotos D, E e F é uma caneta (círculo).
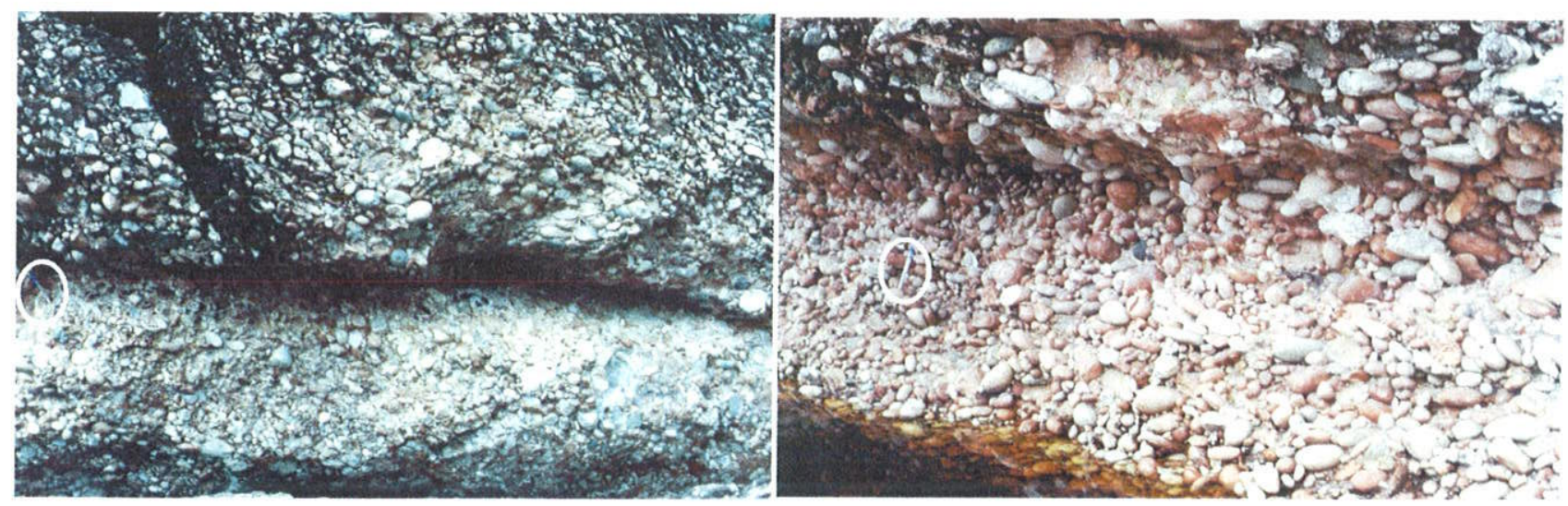

E. Conglomerado com estratificação cruzada acanalada (Rio Ribeirão).

F. Fácies conglomerado. Observar imbricação dos seixos para a direita, indicando paleocorrente para a esquerda (oeste) (Rio Mandassaia). 
Figura V.2. Associação de leque aluvial (Fácies brecha).

Perfil do Córrego da Onça

(afluente do Rio Ribeirão)
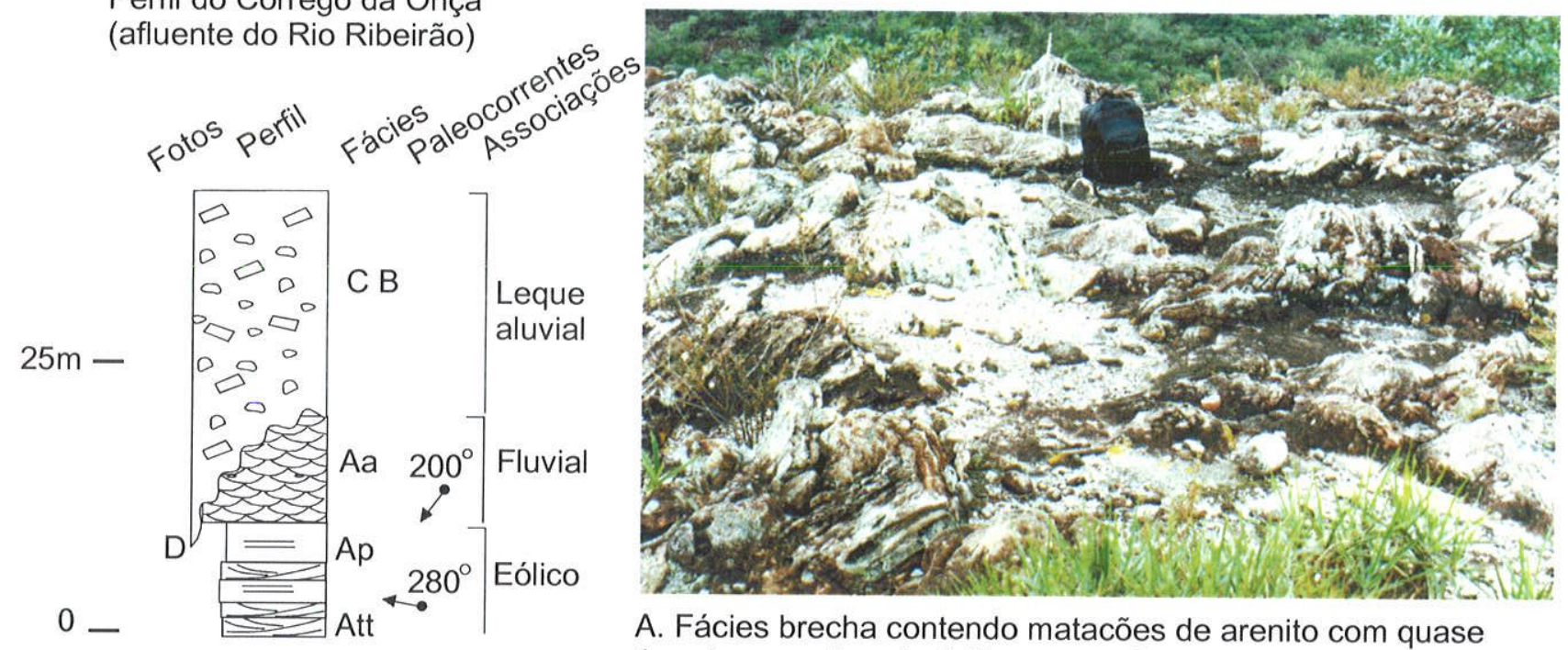

A. Fácies brecha contendo matacões de arenito com quase $1 \mathrm{~m}$ de comprimento (trilha para a Cachoeira do Sossego).

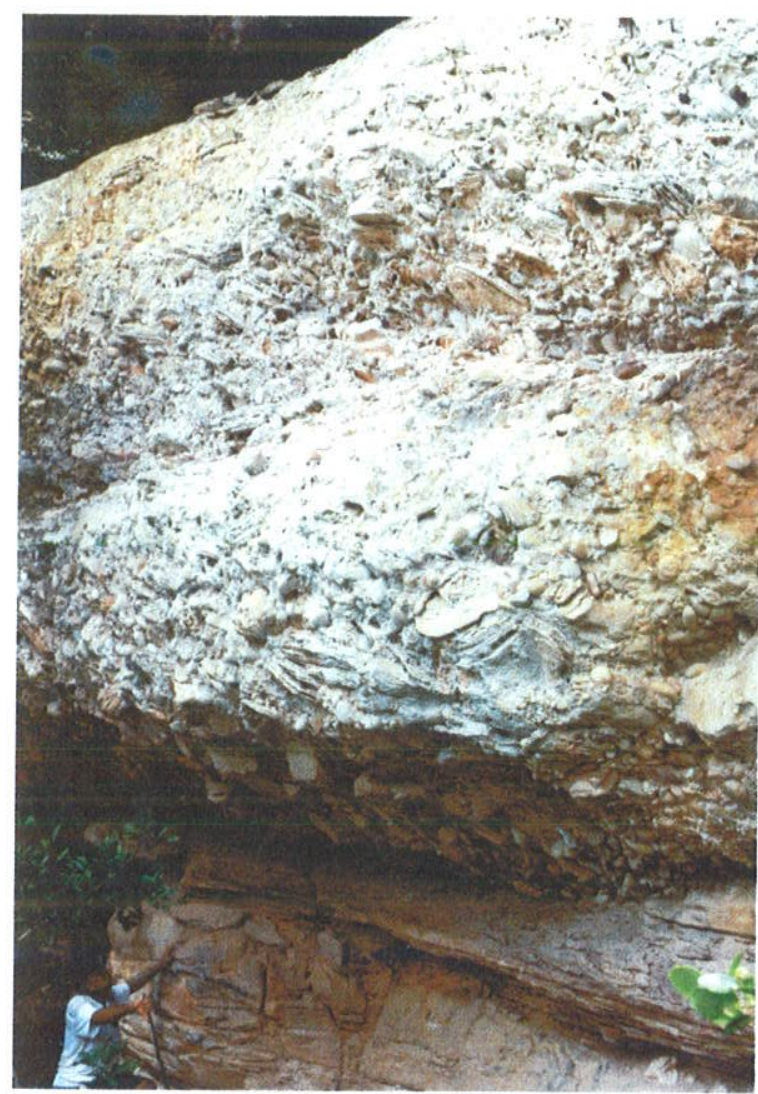

D. Brecha sobreposta erosivamente a arenito eólico (Córrego da Onça).

Perfil do Rio Capivara
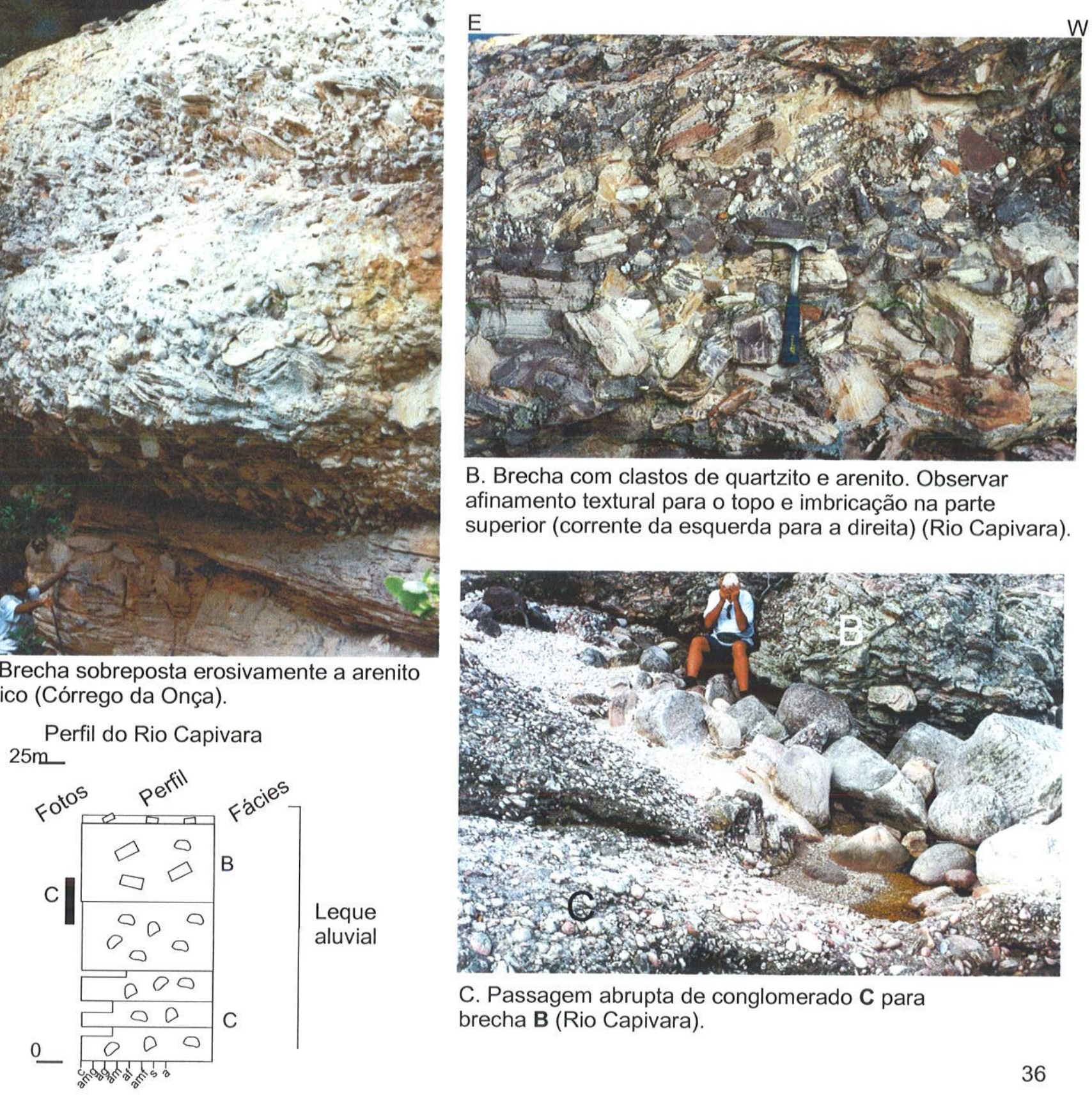

B. Brecha com clastos de quartzito e arenito. Observar afinamento textural para o topo e imbricação na parte superior (corrente da esquerda para a direita) (Rio Capivara).

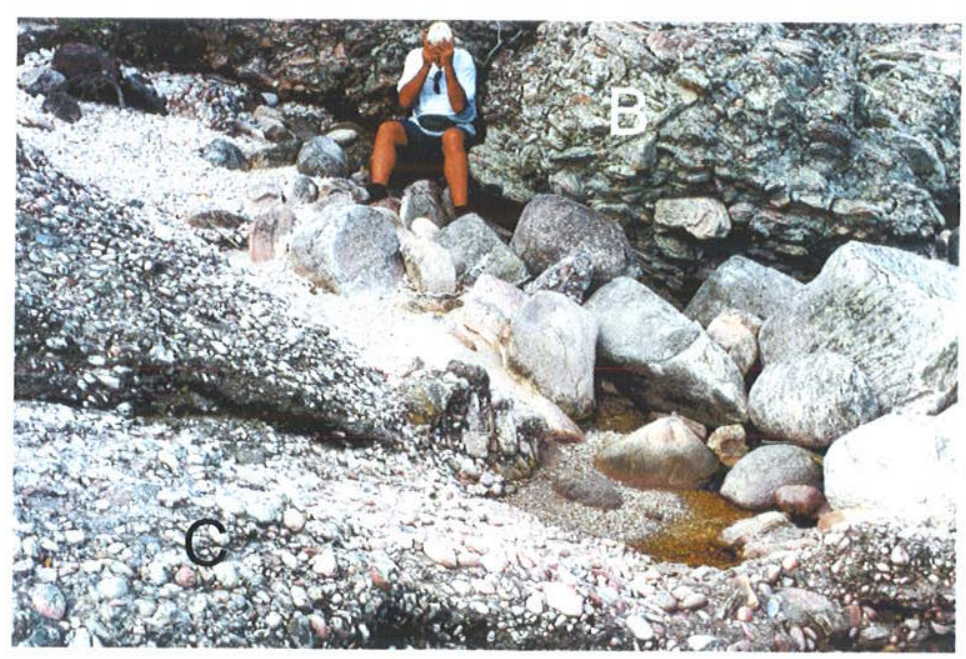

C. Passagem abrupta de conglomerado $\mathbf{C}$ para brecha B (Rio Capivara). 
observa um limite inferior canalizado, e grande contribuição de clastos do substrato (Fig. V.2-D) porém não apresentando grandes extensões laterais.

A fácies brecha B provavelmente está relacionada à parte proximal de leques aluviais, associada a um relevo mais íngreme e com pouco transporte e retrabalhamento por água. $O$ material da própria bacia contido na brecha (blocos angulosos) sugere um fraturamento e fragmentação intraformacional após a deposição e consolidação do sedimento. Em outros casos, ocorrem brechas de natureza local, intercaladas em depósitos fluviais, ou mesmo formadas em depósitos marinhos de tempestades (ver associação marinha shoreface); nestes casos é sugerida a ocorrência de sismos na origem dos clastos intraformacionais angulosos.

\section{LEQUE SUBAQUOSO}

A associação de leque subaquoso é representada por brecha e arenito BA, tendo observada localmente no perfil do Rio Capivara, sobreposta à associação de leque aluvial (fácies brecha B) e sotoposta a tempestitos marinhos (fácies $\mathbf{A h}$ e S), no último ciclo do intervalo superior da Formação Tombador.

A associação de leque subaquoso tem espessura de quase $10 \mathrm{~m}$, e é constituída por estratos, de escala métrica, de brecha gradando a arenito, este com laminações horizontal ou ondulada (Fig. V.3-A). Cada estrato individual apresenta base erosiva (Figs. V.3-B, V.3-C) indicando fluxos vigorosos unidirecionais que escavam (scour) o substrato geralmente arenoso, e depositam brechas maciças ou brechas/conglomerados com estratificação cruzada (tração), seguido de arenitos laminados (regime de fluxo superior).

A presença de clastos arredondados e de feições de imbricação sugere a ação de correntes trativas unidirecionais, enquanto a laminação ondulada dos arenitos (Figs. V.3-D, V.3-E) sugere a ação de ondas de tempestade, indicando uma origem marinha rasa para a associação de fácies. Essa hipótese é reforçada pelo fato da associação BA ser intermediária entre as associações de leque aluvial (brecha, sotoposta) e marinha shoreface (tempestito).

\section{FAN DELTA ESTUARINA}

Sob este título enquadram-se duas sucessões faciológicas: granodecrescente, com conglomerado, arenito grosso com drape síltico, e siltito; e granocrescente.

A sucessão inferior é formada por um conjunto granodecrescente ascendente de três fácies: conglomerado intercalado com siltito (C, S), arenito com drapes de siltito (Aa, Ap, S), e siltitos (S). Os conglomerados exibem estratificação cruzada acanalada, e são bruscamente interrompidos por siltitos (Fig. V.4-A). Os arenitos apresentam estratificação cruzada 
Figura V.3. Associação de leque subaquoso.

Parte do perfil do Rio Capivara
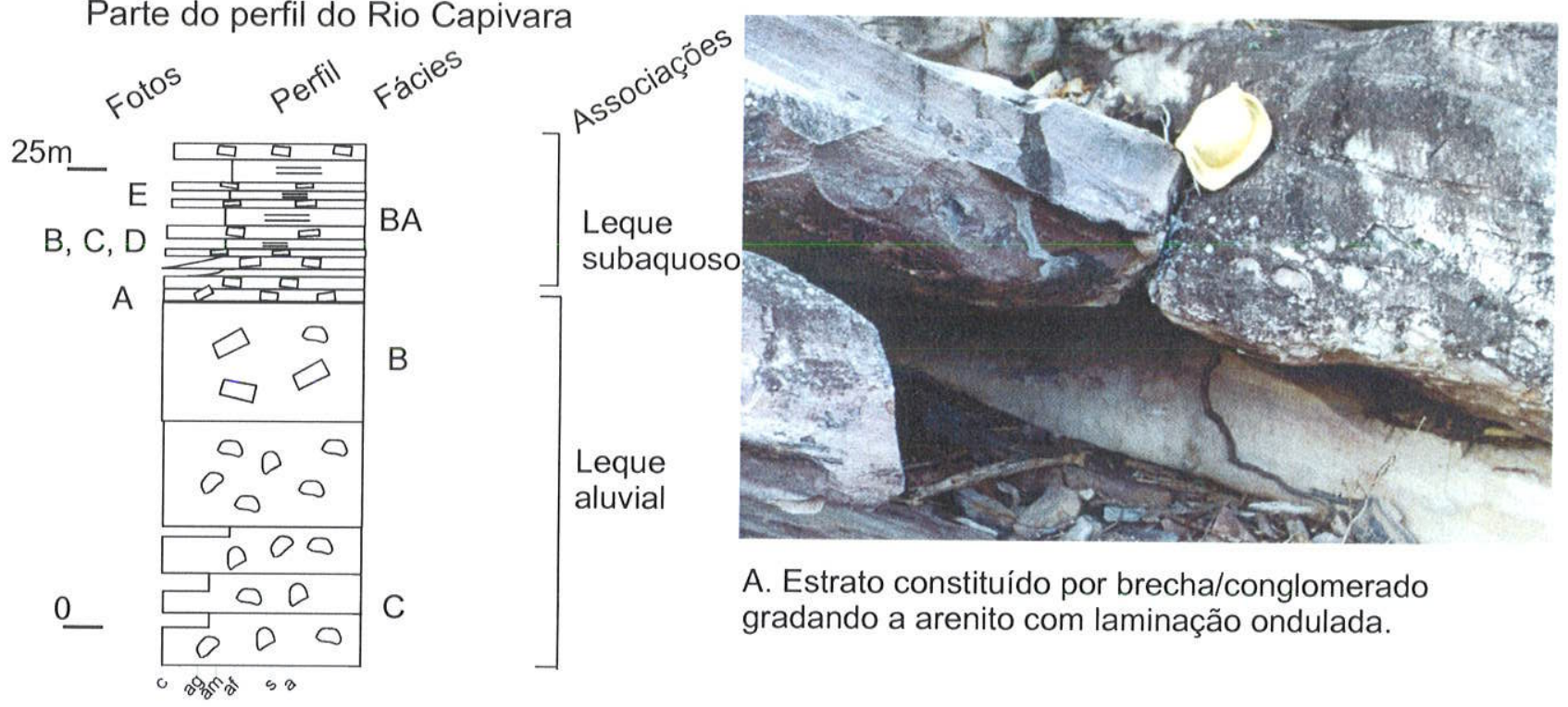

A. Estrato constituído por brecha/conglomerado gradando a arenito com laminação ondulada.
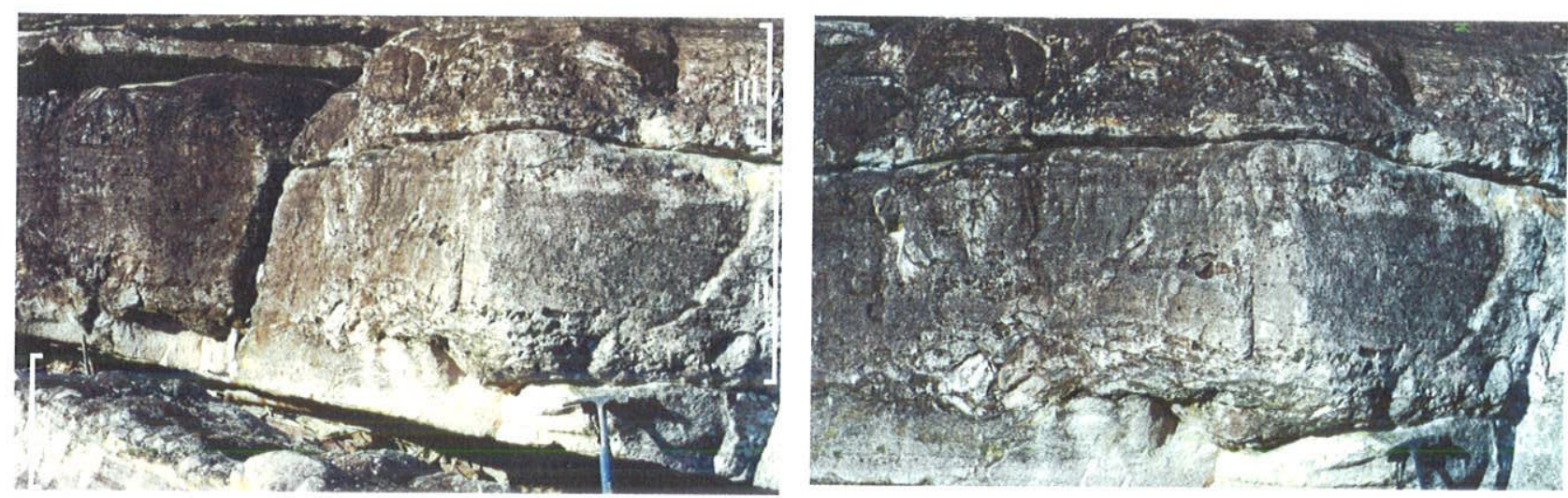

B. Observam-se três estratos (I, II e III) sendo cada um constituído por brecha gradando a arenito com estratificação cruzada seguido de arenito com laminação ondulada. Notar erosão (scour) na base do estrato II.

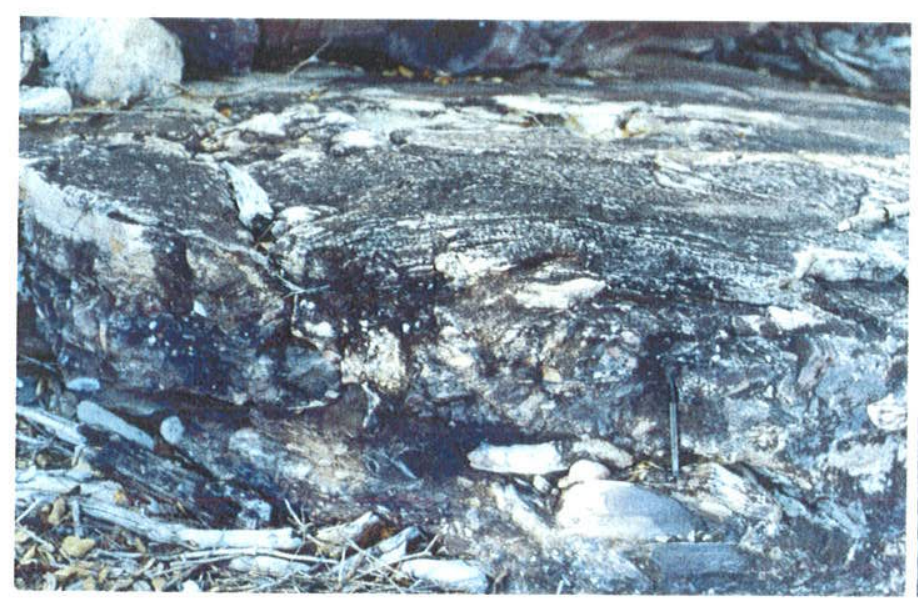

C. Detalhe da foto B, destacando a erosão na base dos estratos.

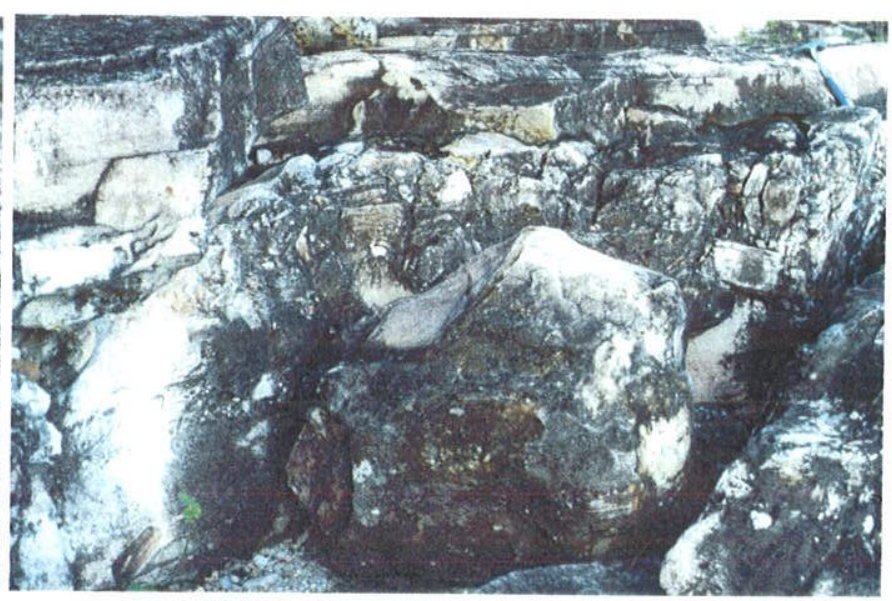

D. Espesso estrato constituído por brecha/ conglomerado gradando a arenito com laminação ondulada.
E. Dois estratos constituídos por conglomerado gradando a arenito com estratificação cruzada (parte inferior), sucedido por brecha gradando a arenito com laminaçao ondulada (hummocky?). 
Figura V.4. Associação fandelta estuarina.

Parte do perfil

da BR-242

(Ponto Mu3)
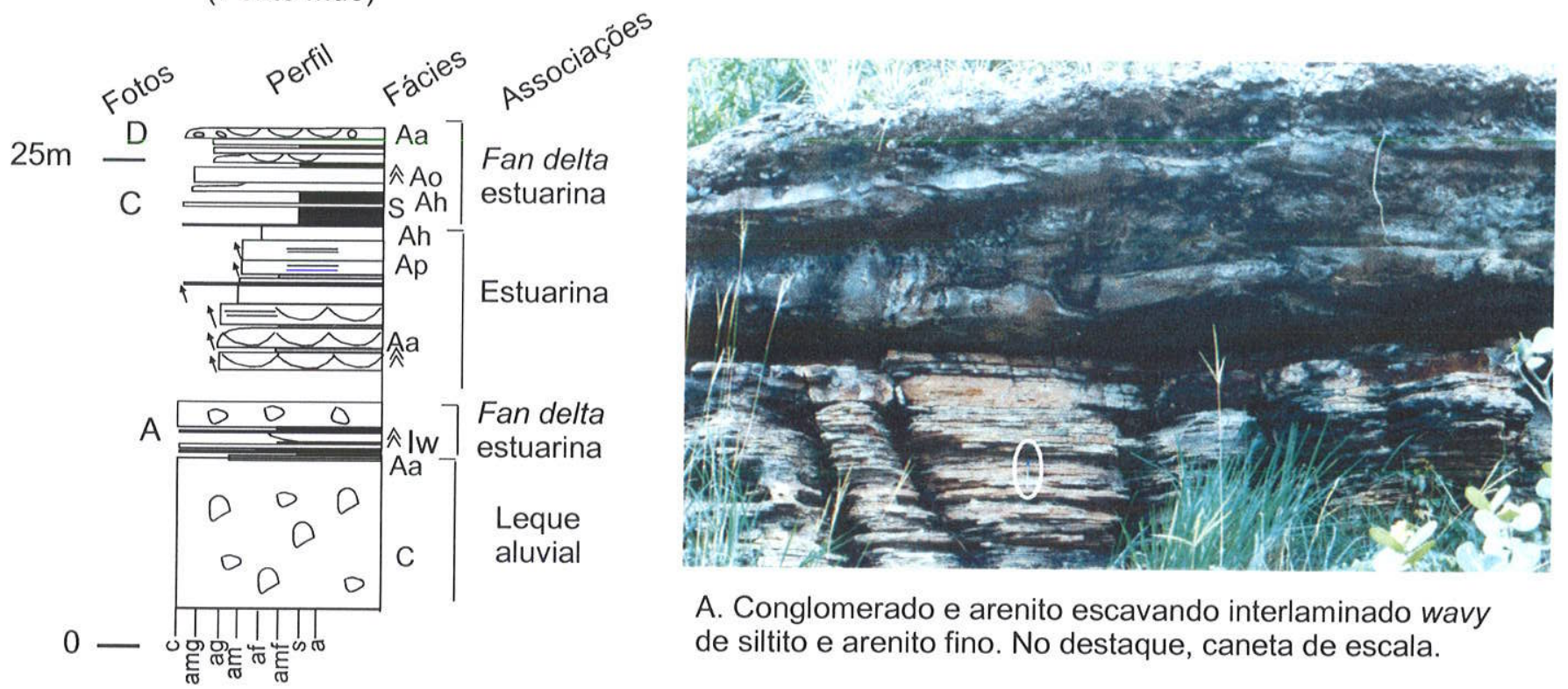

A. Conglomerado e arenito escavando interlaminado wavy de siltito e arenito fino. No destaque, caneta de escala.
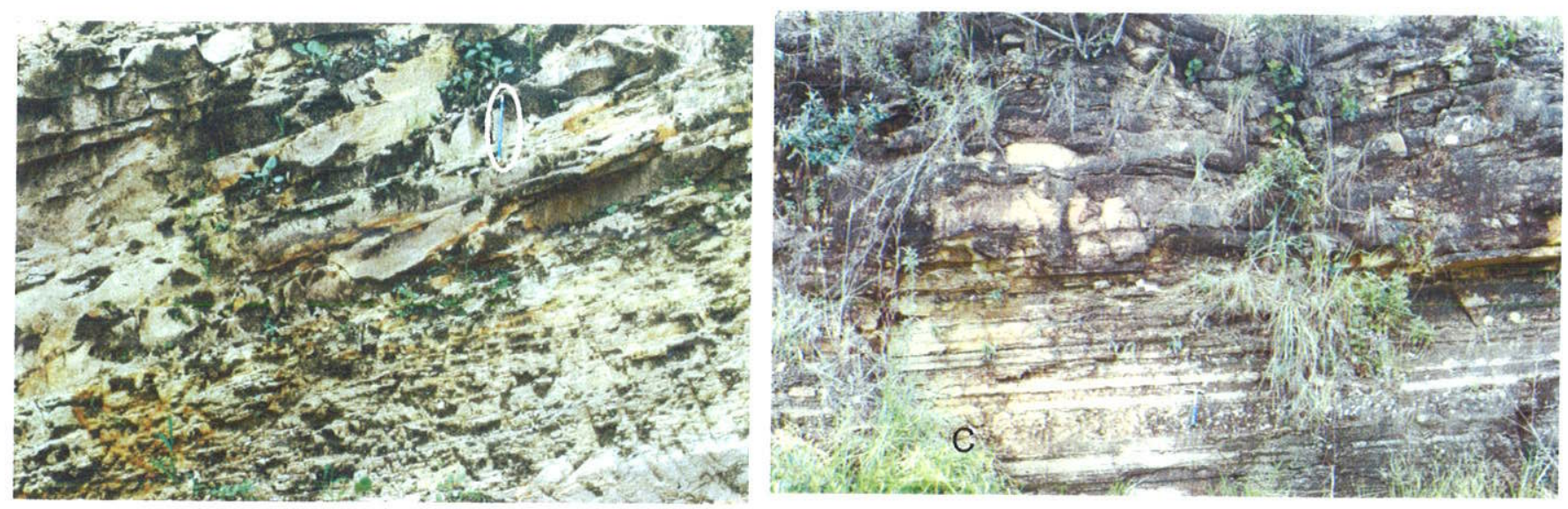

B. Progradação de arenito com estratificação sigmóide C. Siltito/ritmito com intercalação de conglomerado C, sobre arenito com laminação cruzada e flaser. Notar sotopostoa arenito muito grosso com estratificação ângulo mais forte do intervalo superior. Fundo do Hotel cruzada e retrabalhamento por ondas no topo dos estratos Pousada de Lençóis (Pto Le3). No destaque, caneta de escala.

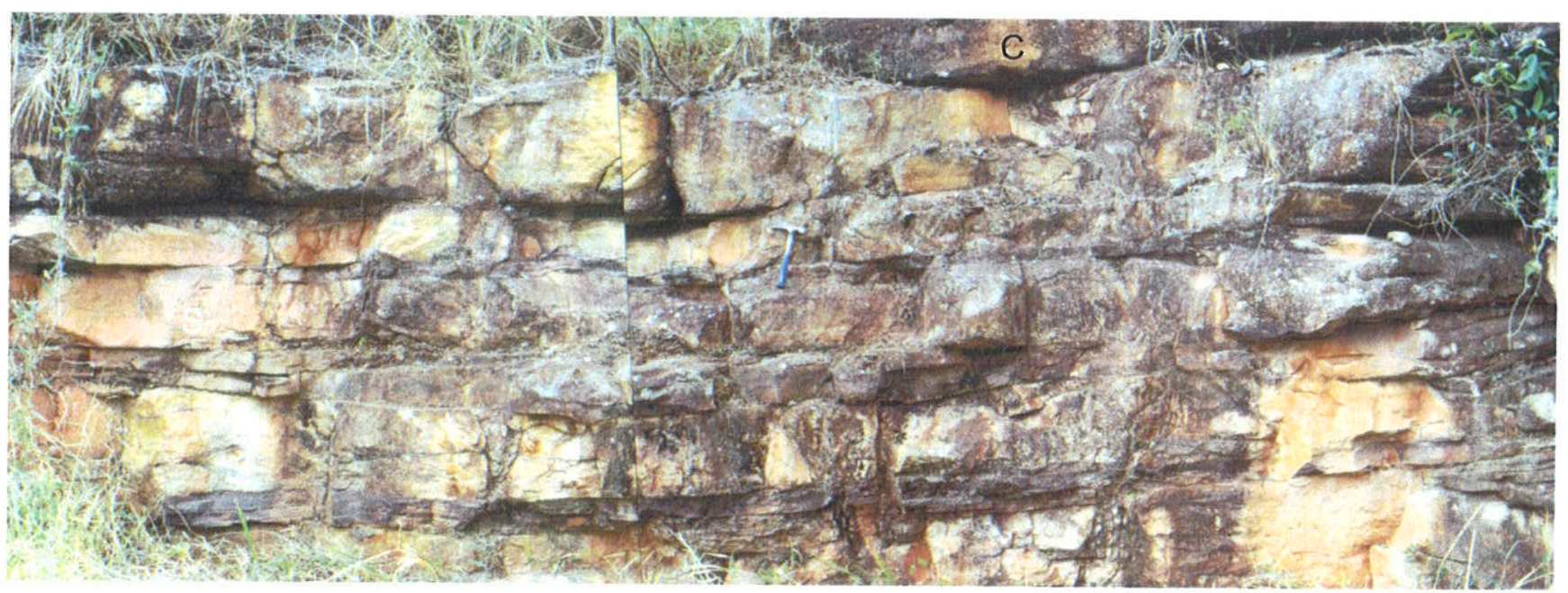

D. Arenito grosso com estratificação cruzada acanalada, com retrabalhamento por onda e drapes/flasers de siltito entre os estratos. Conglomerado $\mathrm{C}$ no topo. 
acanalada, sucedida por laminação horizontal (Aa, Ap); e niveis (drapes) de siltito; para o topo ocorre arenito com provável estratificação ondulada truncante (Ah). A sucessão granodecrescente se completa com um banco de siltito (Fig. V.4-C). O conjunto retrogradante acima descrito, que indica uma evolução geral transgressiva a partir de um leque aluvial inicial, é descrito no último ciclo do intervalo superior da Formação Tombador, no vale do Rio Mucugezinho (BR 242), ponto Mu3.

A segunda sucessão faciológica apresenta uma organização granocrescente ascendente de três fácies. $\mathrm{Na}$ base, siltitos e arenitos finos, em parte formando estratos rítmicos gradacionais (fácies $\mathbf{S}, \mathbf{R}$ ) e portando um corpo tabular de conglomerado com $0,3 \mathrm{~m}$ de espessura (Fig. V.4-C). Seguem-se estratos de arenito, com espessura 0,2 a $0,5 \mathrm{~m}$ e estratificação cruzada acanalada (fácies $\mathbf{A a}$ ), separados entre si por intercalações centimétricas (drapes) de siltito (Fig. V.4-C). A sucessão se completa com arenitos com estratificação cruzada acanalada e niveis de seixo. Esta progradação de elementos fluviais sobre depósitos marinhos, interpretada como fan delta estuarina, ocorre sobreposta à sucessão anterior na BR-242, ponto Mu3.

Outro afloramento que se enquadra no modelo em epígrafe, é encontrado nos fundos do Hotel Pousada de Lençóis (Ponto Le23). Aqui duas fácies se sucedem em um arranjo progradante: abaixo, estratos centimétricos de arenitos finos com laminação cruzada freqüentemente retrabalhada por ondas, fácies Ao (com flasers de siltito), e acima estratos de tamanho decimétrico de arenito fino/médio, sigmoidal, com superficies retrabalhadas por ondas (Fig. V.4-B). Outra sucessão semelhante a esta, portando conglomerado no topo da sucessão, é encontrada próximo a Pousada Lavramor.

\section{FLUVIAL TORRENCIAL}

A associação fluvial torrencial compreende arenitos médios a muito grossos, freqüentemente exibindo lâminas conglomeráticas formadas por seixos de quartzo leitoso (alcançando $1 \mathrm{~cm}$ ). Os arenitos apresentam estratificações cruzada acanalada e horizontal (Fig. V.5-A, -B) e formam corpos espessos com espessura variando de poucos até uma dezena de metros. Entre esses corpos ocorrem delgados intervalos de ritmito arenito/siltito ou siltito, fácies $\mathbf{R}, \mathbf{S}$, ou siltito e arenito fino com laminação cruzada por ondas, fácies Ao (Fig. V.5-B).

Os arenitos com estratificações cruzada acanalada e horizontal constituem depósitos fluviais torrenciais, que se formam a partir de correntes tracionais rasas de regime de fluxo superior. A intercalação dessas fácies com sedimentos finos marinhos revela ciclos de alta freqüência, com os arenitos fluviais indicando fases regressivas de ativo suprimento, enquanto os siltitos/ritmitos evidenciam fases transgressivas de afogamento marinho. 
Figura V.5. Associação fluvial torrencial.

Parte do perfil da margem esquerda do Rio Mucugezinho (Pontos Mu29/Mu30)

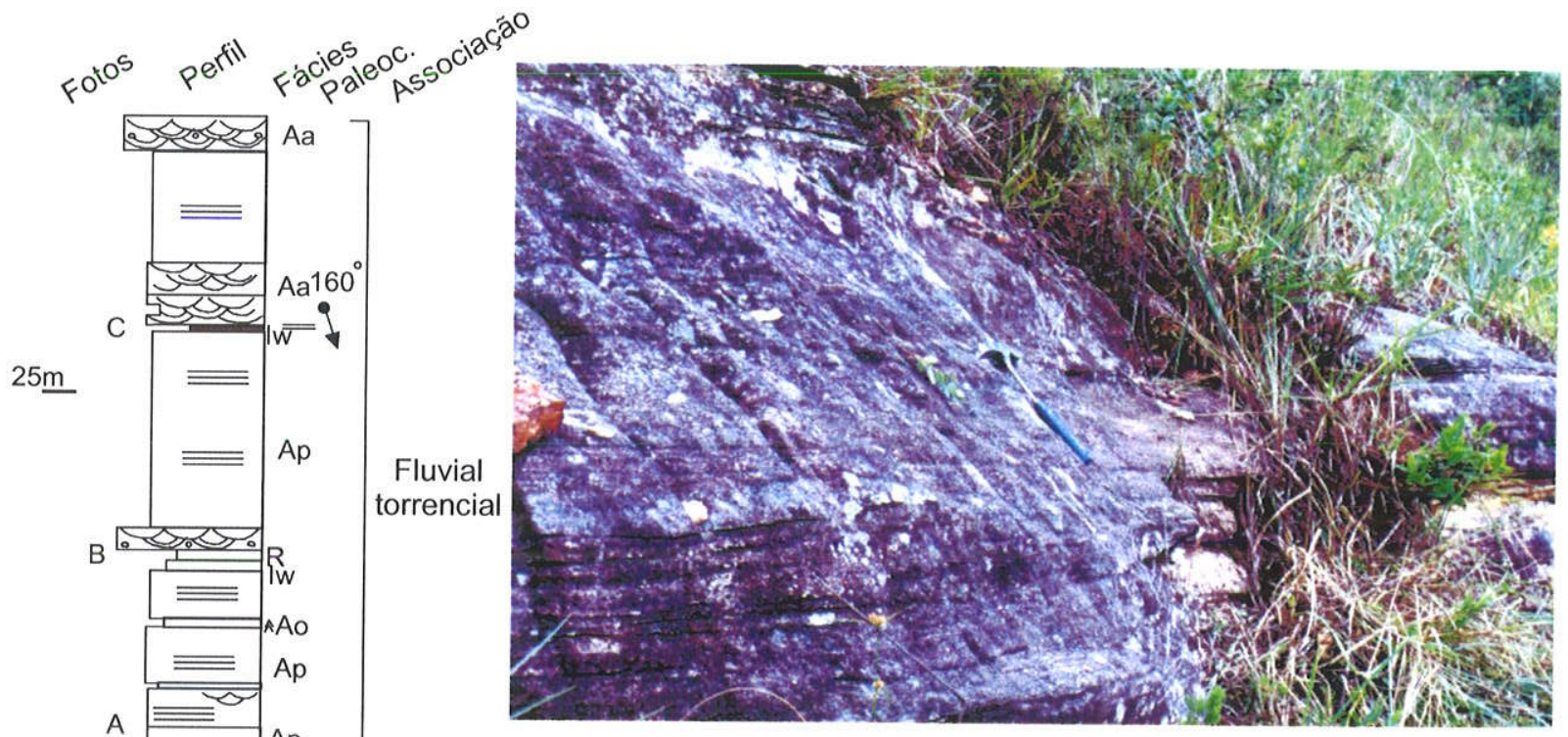

A. Arenito médio com laminação cruzada e horizontal.

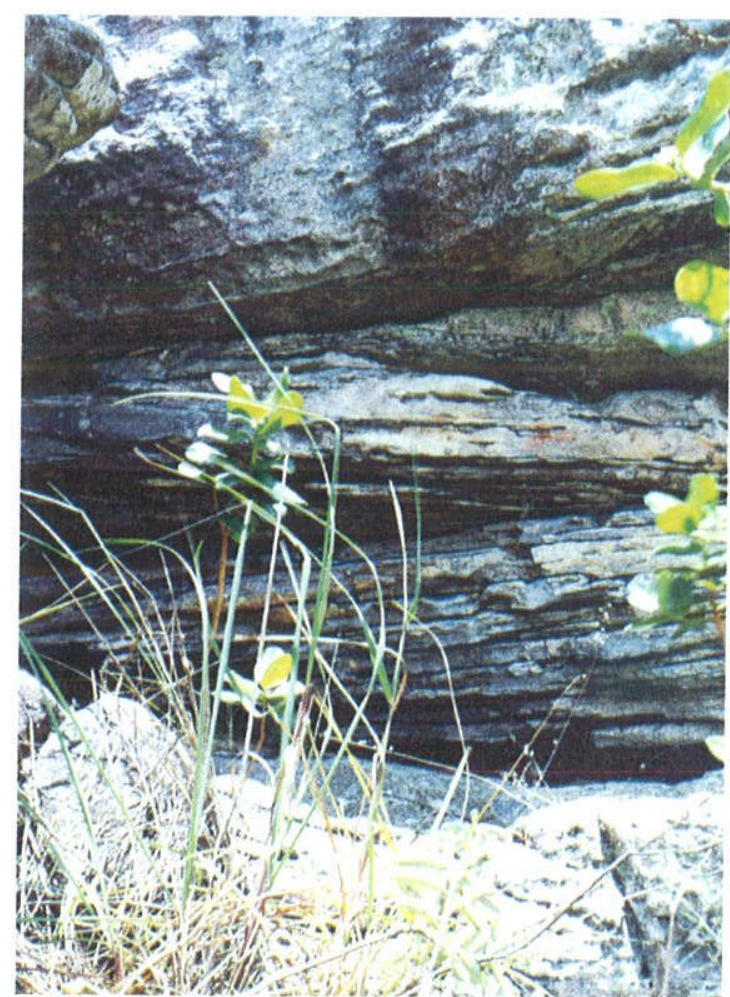

C. Arenito com estratificação cruzada sobreposto a siltito.

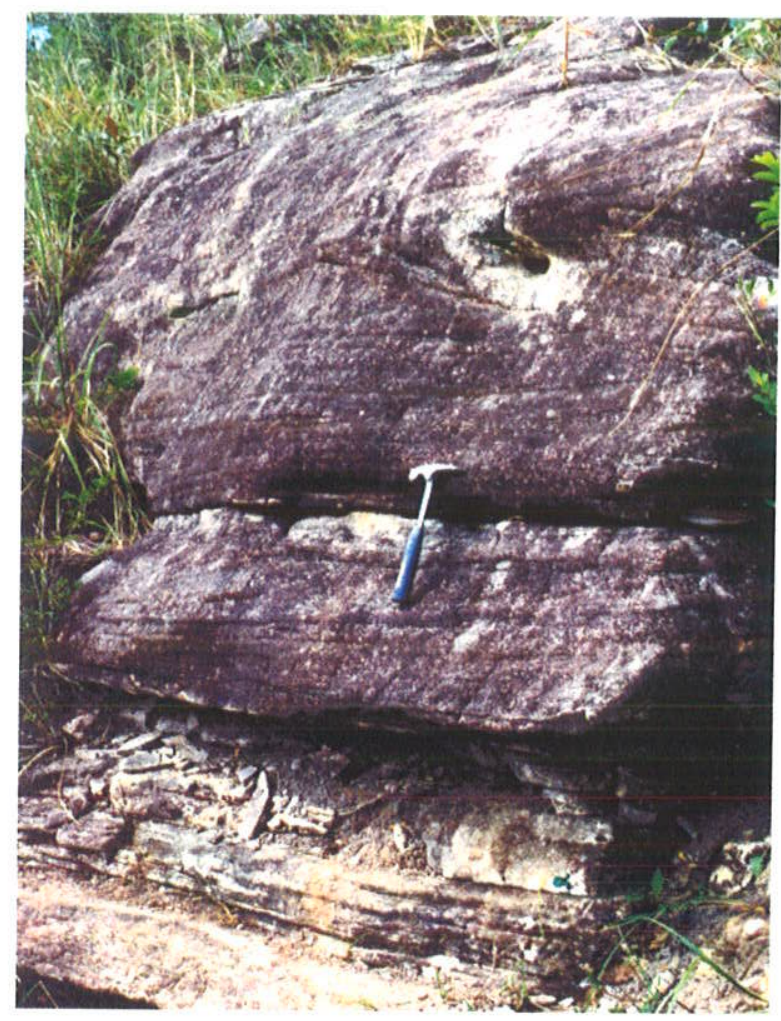

B. Arenito com estratificação cruzada e laminação horizontal sobreposto a ritmito. 
Esta associação ocorre apenas ao norte da área de estudo, em ambos os lados do vale do Rio Mucugezinho (Pontos Mu29/30 e sul do Mu1), encontrando-se no último ciclo do intervalo superior da Formação Tombador. Aqui as paleocorrentes apresentam sentido preferencial para sul.

\section{FLUVIAL}

A associação fluvial compreende arenitos conglomeráticos com estratificação cruzada acanalada ACa, arenitos médios a grossos com estratificações cruzadas acanalada e tabular, Aa At, e ocasionalmente arenito fino com laminação cruzada clino-ascendente Ar.

$\mathrm{Na}$ figura V.6-A observam-se camadas de arenito médio/grosso com estratificação cruzada acanalada de médio porte e geometria lenticular. A base do corpo arenoso apresenta feição erosiva, tipica de canal fluvial. Também são vistos seixos centimétricos de arenito e quartzito dispersos nos arenitos desta fácies, ou níveis intercalados de seixos (Fig. V.6-B); em planta os festoons são bastante evidentes (Fig. V.6-C). O conjunto se apresenta sob a forma de "caixa", sem nenhuma tendência textural evidente.

A fácies At consiste de arenitos médios a grossos com estratificação cruzada tabular, com as espessuras dos estratos alcançando poucos decimetros; geralmente se associa à fácies arenito com estratificação cruzada acanalada Aa (Fig. V.6-D). A fácies Ar é composta de arenitos finos/médios com estratificação cruzada de pequeno porte (sets com espessura 5$10 \mathrm{~cm}$ ), e arenitos finos com laminação cruzada clino-ascendente, formados pela migração de marcas onduladas a partir de fluxos unidirecionais contínuos (Fig. V.6-E).

As estratificações cruzadas acanalada e tabular são geradas pela migração de dunas ou megaondulações de crista sinuosa e reta, sob regime de fluxo inferior, a partir de fluxos trativos unidirecionais. Essas fácies estão associadas a canais arenosos entrelaçados, com paleocorrentes predominantemente no sentido sudoeste e oeste $\left(\mathrm{N} 220^{\circ}, \mathrm{N} 300^{\circ}\right)$ no Rio Ribeirão de Baixo, considerando-se o último ciclo do intervalo superior da Formação Tombador.

\section{FLUVIAL COSTEIRA}

Esta associação de fácies é ilustrada no perfil do Rio Mucugezinho, afloramento "Portal" da rodovia BR-242 (Ponto Mu23), intervalo inferior da Formação Tombador.

A associação faciológica fluvial costeira é amplamente dominada por arenitos finos a médios, segundo estratos tabulares com 0,2 a $0,5 \mathrm{~m}$ de espessura, com estratificação cruzada acanalada ou laminações horizontal e cruzada, modificadas por ondas e lentes de flaser argiloso (Fig. V.7-A, -B, -C). Afloramento próximo, na descida para o Bar Cachoeira (Ponto 
Figura V.6. Associação fluvial.

Parte do perfil do Rio Ribeirão
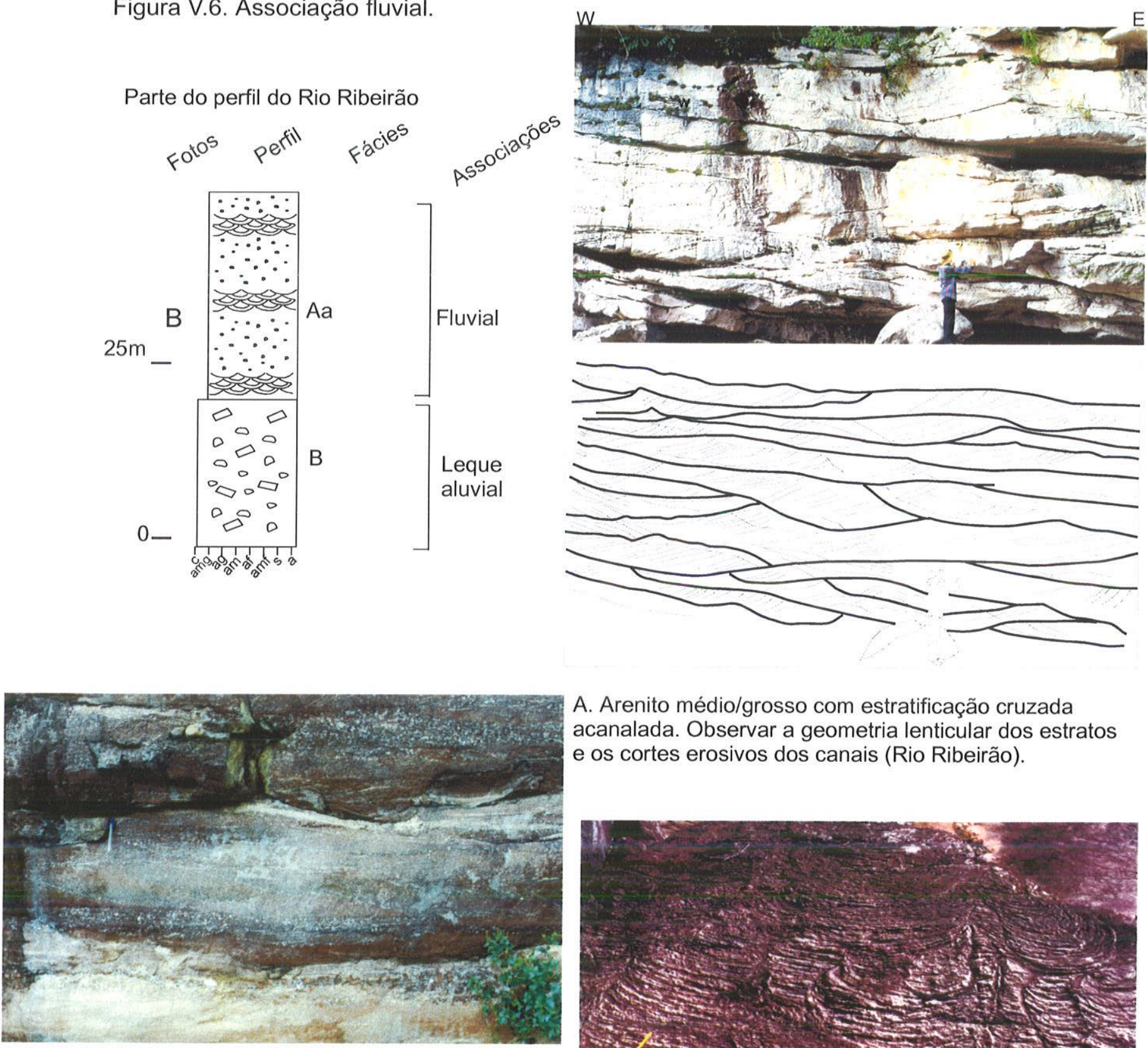

B. Arenito conglomerático com estratificação cruzada acanalada Aa (trilha para a Cachoeira do Sossego).

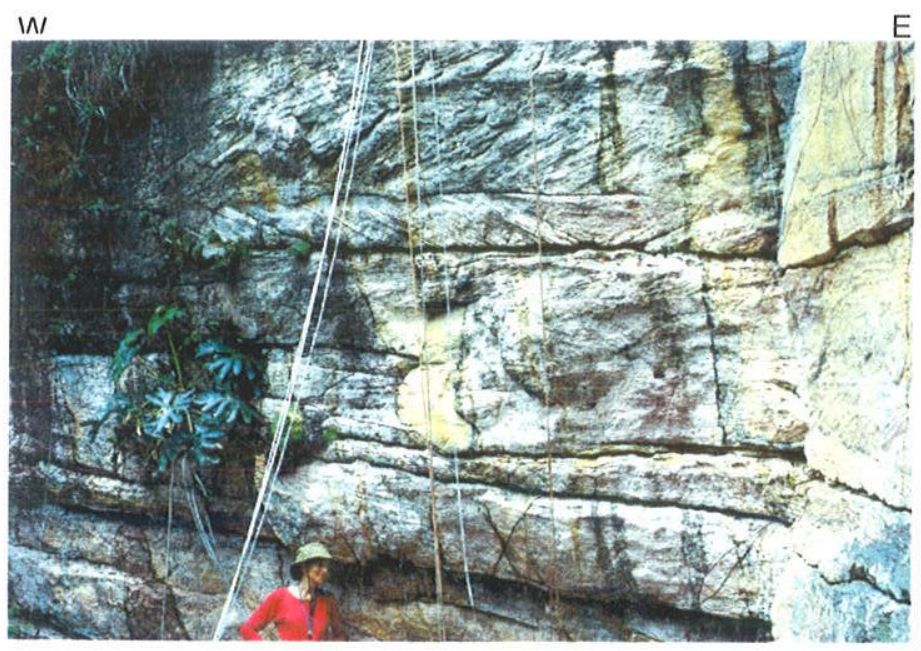

A. Arenito médio/grosso com estratificação cruzada acanalada. Observar a geometria lenticular dos estratos e os cortes erosivos dos canais (Rio Ribeirão).

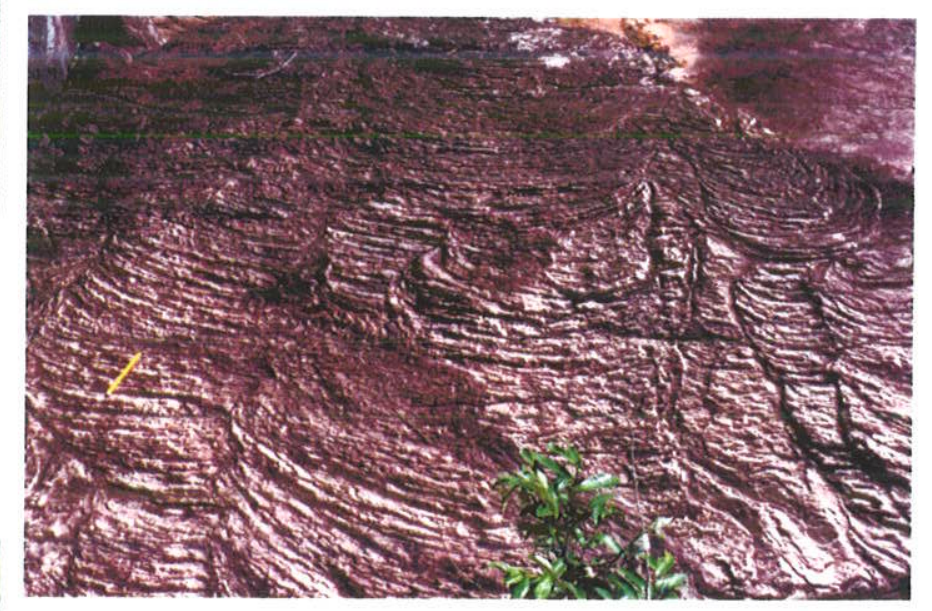

C. Arenito com estratificação cruzada acanalada vista em planta (festoon - Rio Mucugezinho).

D. Arenito médio a grosso com estratificações cruzadas tabular e acanalada (Rio Ribeirão).

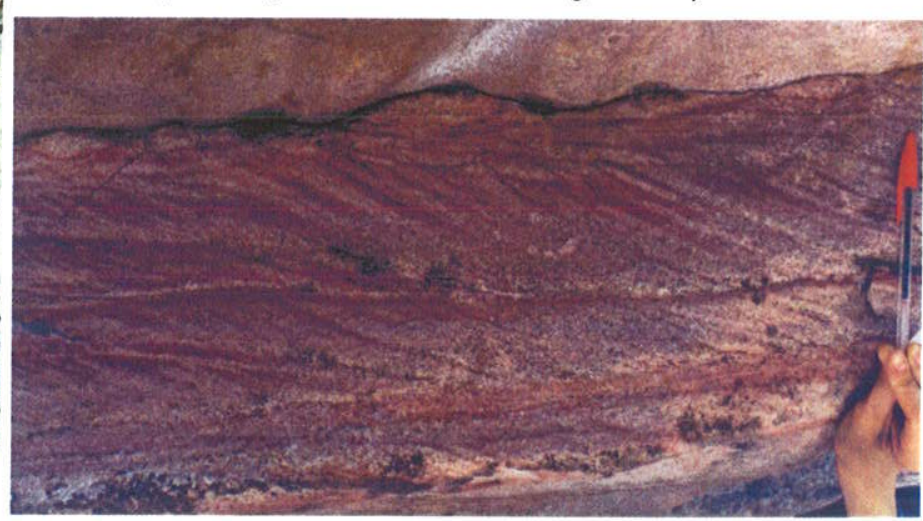

E. Arenito com laminação cruzada sobreposta a pequenos sets de estratificação cruzada (Rio Ribeirão). 
Figura V.7. Associação fluvial costeira (BR-242).
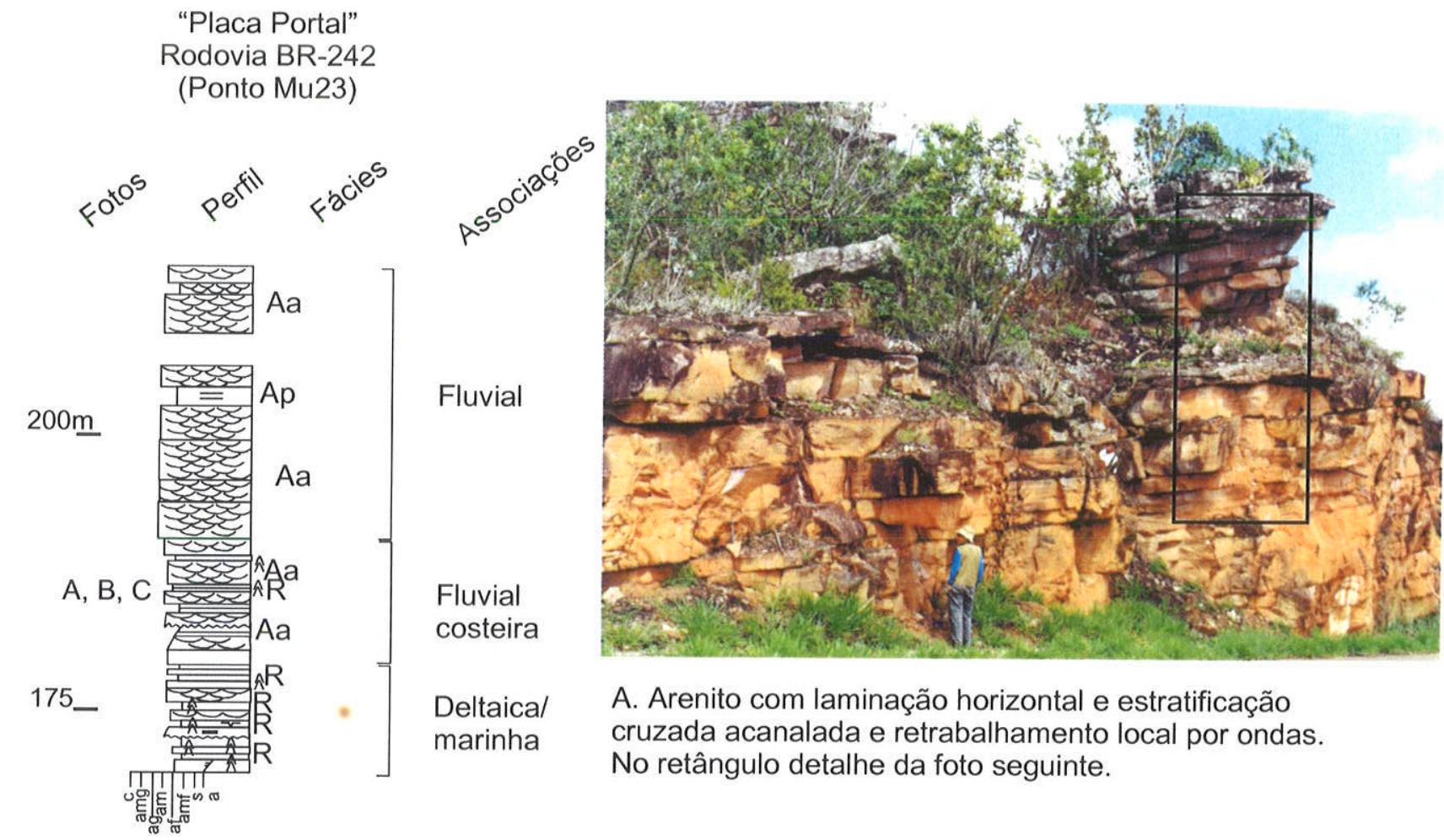

Deltaica/ marinha

A. Arenito com laminação horizontal e estratificação cruzada acanalada e retrabalhamento local por ondas. No retângulo detalhe da foto seguinte.
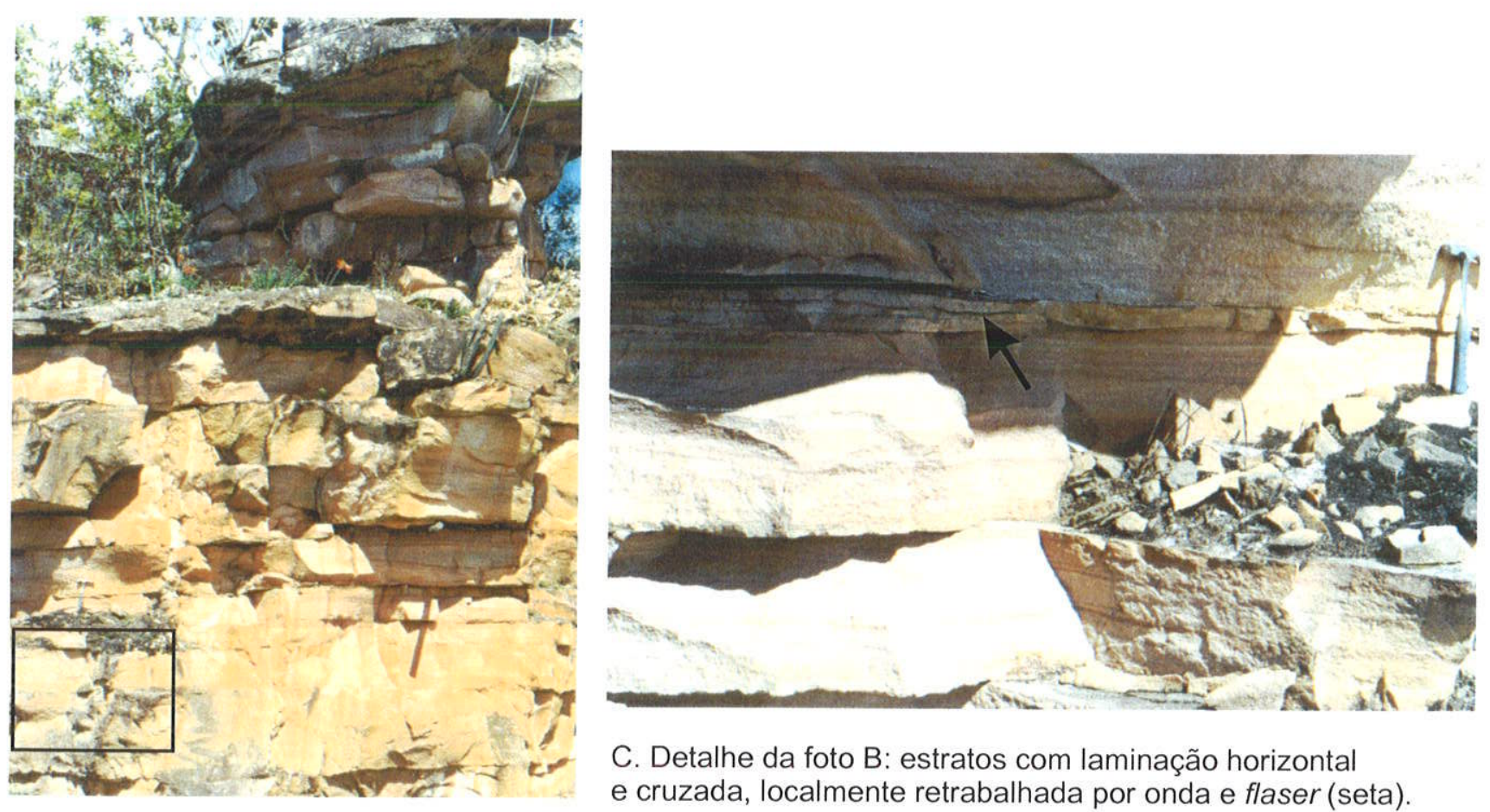

C. Detalhe da foto B: estratos com laminação horizontal e cruzada, localmente retrabalhada por onda e flaser (seta).

B. Estratos tabulares de arenito, detalhados na foto seguinte. 
Mu15), revela a presença de drapes sílticos nas lâminas inclinadas de alguns delgados estratos cruzados tabulares de arenito, e nas ondulações por ondas separando os estratos; neste afloramento também é comum a presença de laminações cruzadas clino-ascendentes. A associação flúvio-costeira é subjacente a depósitos fluviais, observados em afloramentos da descida para a Toca da Marina.

\section{EÓLICA}

A associação eólica engloba as fácies arenito médio com estratificação cruzada tabular tangencial Att e arenito médio com laminação horizontat Ap (Fig. V.8-A). Tal associação é muito comum no intervalo superior da Formação Tombador, geralmente formando o topo de cada ciclo/seqüência (leque aluvial - fluvial - eólico) ou mesmo sobrepondo-se diretamente ao leque aluvial (Fig. V.8-B). No último ciclo do referido intervalo, os depósitos eólicos associamse a sedimentos litorâneos, como observado nos perfis dos rios Mucugezinho e Capivara (Pontos Mu50/51 e Ca1, ver próximo capítulo).

A fácies Att é constituída por arenito fino a grosso, bem selecionado e com os grãos grossos arredondados, com estratificação cruzada tabular tangencial de médio/grande porte e inclinação das lâminas frontais podendo passar de $35^{\circ}$, e tendo ainda uma longa cauda assintótica (Figs. V.8-A, V.8-B). Em lâmina delgada $90 \%$ dos grãos são de quartzo com sobrecrescimento, feldspato, além de fragmentos de rocha, turmalina e zircão (Fig. V.8-C). Também podem ser observadas, em planta, marcas onduladas assimétricas de crista reta. A espessura da fácies alcança até $30 \mathrm{~m}$. As paleocorrentes eólicas variaram entre noroeste $\left(\mathrm{N} 300^{\circ}, \mathrm{N} 330^{\circ}\right)$ e nordeste $\left(\mathrm{N} 30^{\circ}\right)$; no último ciclo do intervalo superior, vale do Mucugezinho, o sentido dos ventos era para leste-sudeste (entre $80^{\circ}$ e $130^{\circ}$ ).

Os arenitos da fácies Att são interpretados como depósitos de dunas. A medida que o vento perde energia, ou a partir de um vento secundário, são depositados na frente das dunas areias com marcas onduladas migrantes de crista reta (ripple drift). Intercalado aos arenitos com estratificação cruzada de grande porte (dunas) ocorrem arenitos médios com laminação horizontal Ap; a laminação horizontal resulta a partir de processo tracional, com ventos de alta velocidade, em regime de fluxo superior. É provável que esteja relacionada a depósitos de lençol de areia (sandsheet - Kocurek 1996). 
Figura V.8. Associação eólica.

Perfil de parte do intervalo

superior do Rio Mucugezinho
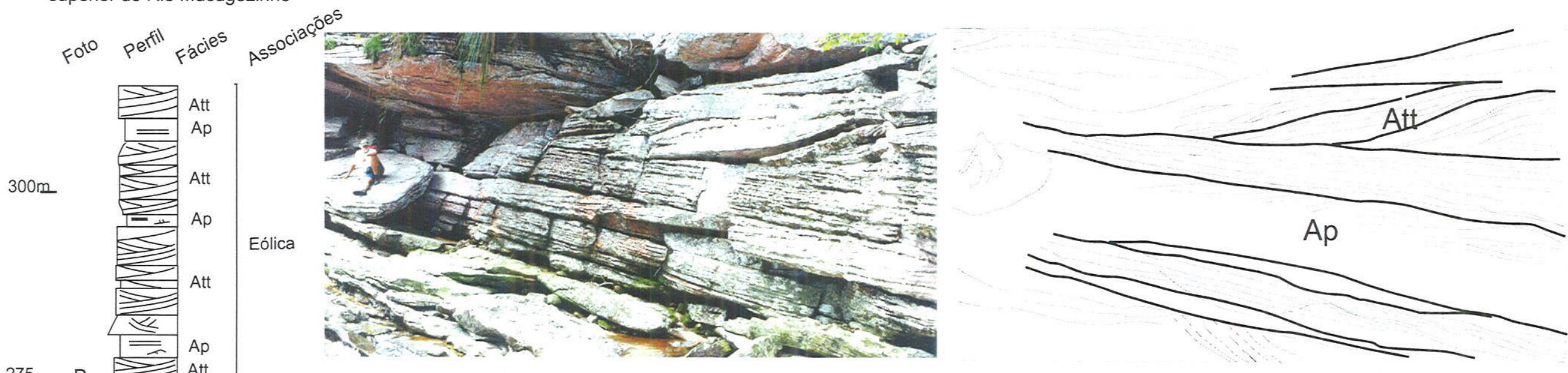

A. Arenitos com estratificação cruzada tabular tangencial Att intercalados com arenitos com laminação horizontal Ap (Rio Lençóis).

$275-\mathrm{B} A \mathrm{Att}$ A

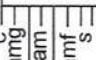
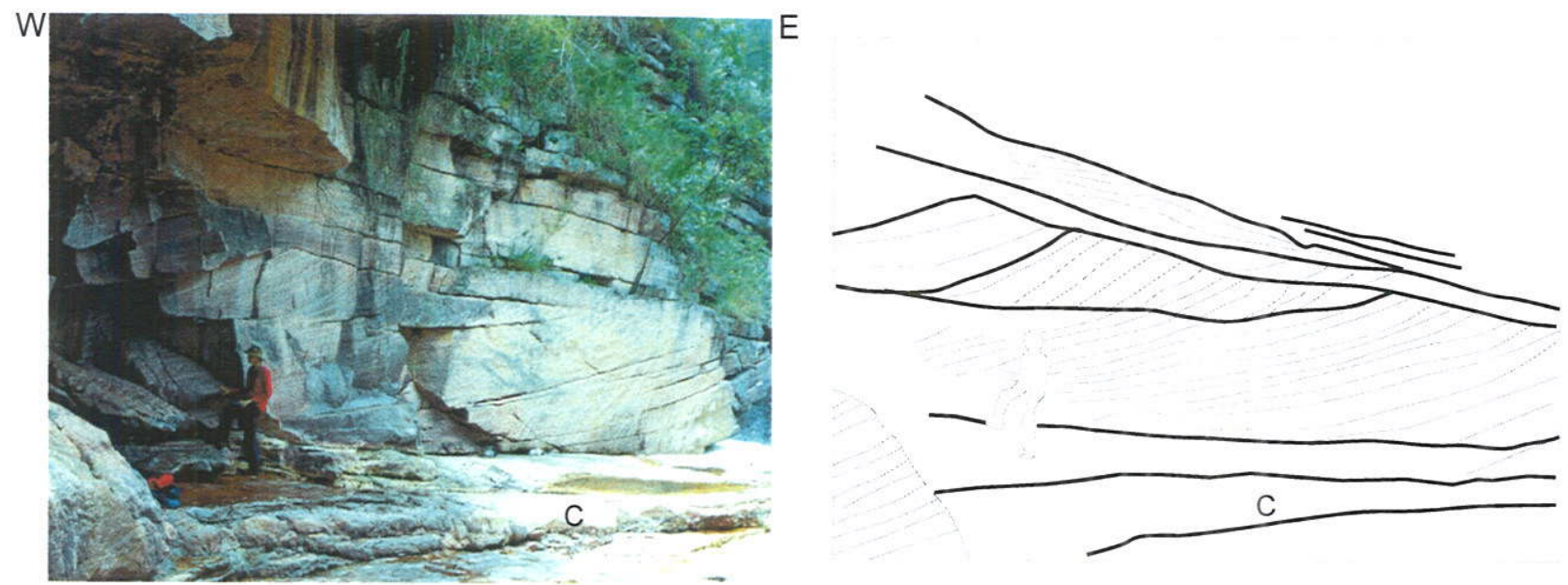

B. Arenito com estratificação cruzada tabular tangencial sobreposto a conglomerado C. As linhas के mais grossas marcam limites dos estratos e superfícies de reativação (Rio Mucugezinho, pto Mu39).

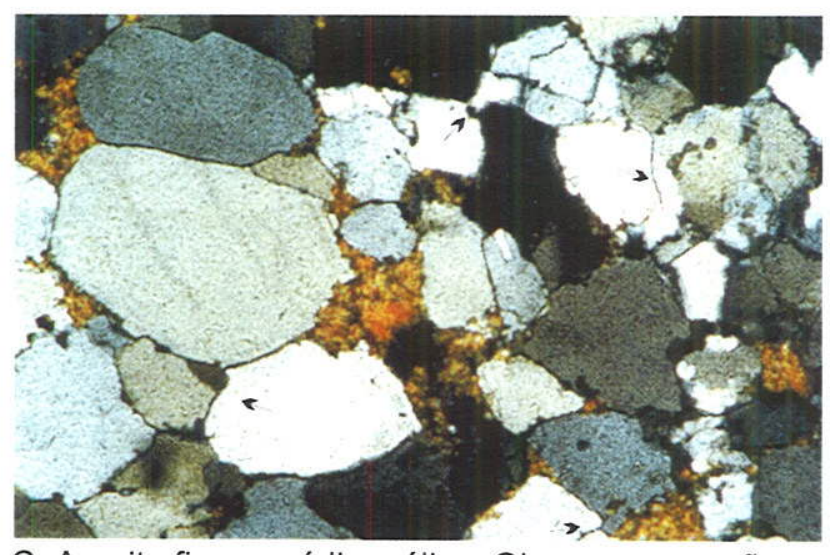

C. Arenito fino a médio, eólico. Observam-se grãos de quartzo e feldspato, arredondados a angulosos, $e$ sobrecrescimento de quartzo (setas) com cimento carbonático corroendo os grãos. Nicóis cruzados, aumento 5x (Morro do Pai Inácio). 


\section{LITORÂNEA/PRAIA}

Essa associação compreende predominantemente arenitos com laminação horizontal Ap e cruzada por onda Ao, e arenito com estratificação cruzada de baixo ângulo $\mathbf{A b a}$.

Um bom exemplo desta associação pode ser visto na Pedreira do Cristalito, próxima da BR-242 (Ponto Mu14), com as fácies Ap e Aba. A fácies Ap consiste de arenito fino/médio, regular a bem selecionado, com laminação horizontal que reflete um regime de fluxo superior (Figs. V.9-A, V.9-B). Em lâmina delgada nota-se orientação dos minerais e intensa cimentação caracterizada por sobrecrescimento de quartzo. Os arenitos com estratificação cruzada de baixo ângulo e horizontal compõem a estratificação tipo swash da praia (Fig. V.9-A).

Marcas onduladas simétricas e de crista reta (fácies Ao) apresentam várias ou apenas duas orientações para as cristas, como se observa respectivamente nas imediações do Bar Mucugezinho (junto à rodovia BR-242, ponto Mu6), e na foz do Rio Lapão (Ponto La9). A fácies Ao é composta por arenitos finos com laminação cruzada por ondas e ocasionalmente flaser. As cristas tendem a ser retas, localmente bifurcantes e pontiagudas, de origem muito rasa (Figs. V.9-C, V.9-D). Em planta, na Pedreira Cristalito, foram medidas direções das cristas das ondas para $\mathrm{N} 125^{\circ}$ e $\mathrm{N} 200^{\circ}$.

Em alguns locais, e mesmo assim de ocorrência rara, verificam-se feições formadas a partir da ação das marés associadas aos sedimentos depositados nesse contexto litorâneo; essa atuação das marés nos sedimentos litorâneos ocorre apenas na passagem para a Formação Caboclo. As feições indicativas da atuação de marés, como por exemplo estratificação cruzada espinha-de-peixe e flaser, estão bem expostas na foz dos rios Mucugezinho e Lapão. Os arenitos finos/médios com estratificação cruzada espinha-de-peixe (fácies Ahb) são formados por sets de estratos tabulares-tangenciais que mergulham em sentidos opostos (Fig. V.9-E). Na foz do Rio Lapão esses arenitos estão associados à prováveis estratificações cruzadas tipo swaley, atestando a origem marinha rasa dos depósitos.

\section{DELTAICA TIPO GILBERT}

A associação deltaica do tipo Gilbert só foi encontrada na rodovia BR-242 (Ponto Mu1A), como parte do último ciclo do intervalo superior da Formação Tombador.

Esta associação é formada por arenitos, dispostos em camadas horizontais (topsets) que gradam a camadas inclinadas frontais (foresets). As superficies que delimitam estas camadas representam superfícies deposicionais inclinadas, com altura de $2 \mathrm{~m}$ e ângulo de $15^{\circ}$, localmente $25^{\circ}$ (Fig. V.10-A); dentro das camadas inclinadas ocorrem estratos cruzados acanalados e tabulares. O conjunto arenoso topset-foreset tem espessura de $13 \mathrm{~m}$, está 
Figura V.9. Associação litorânea/praia.
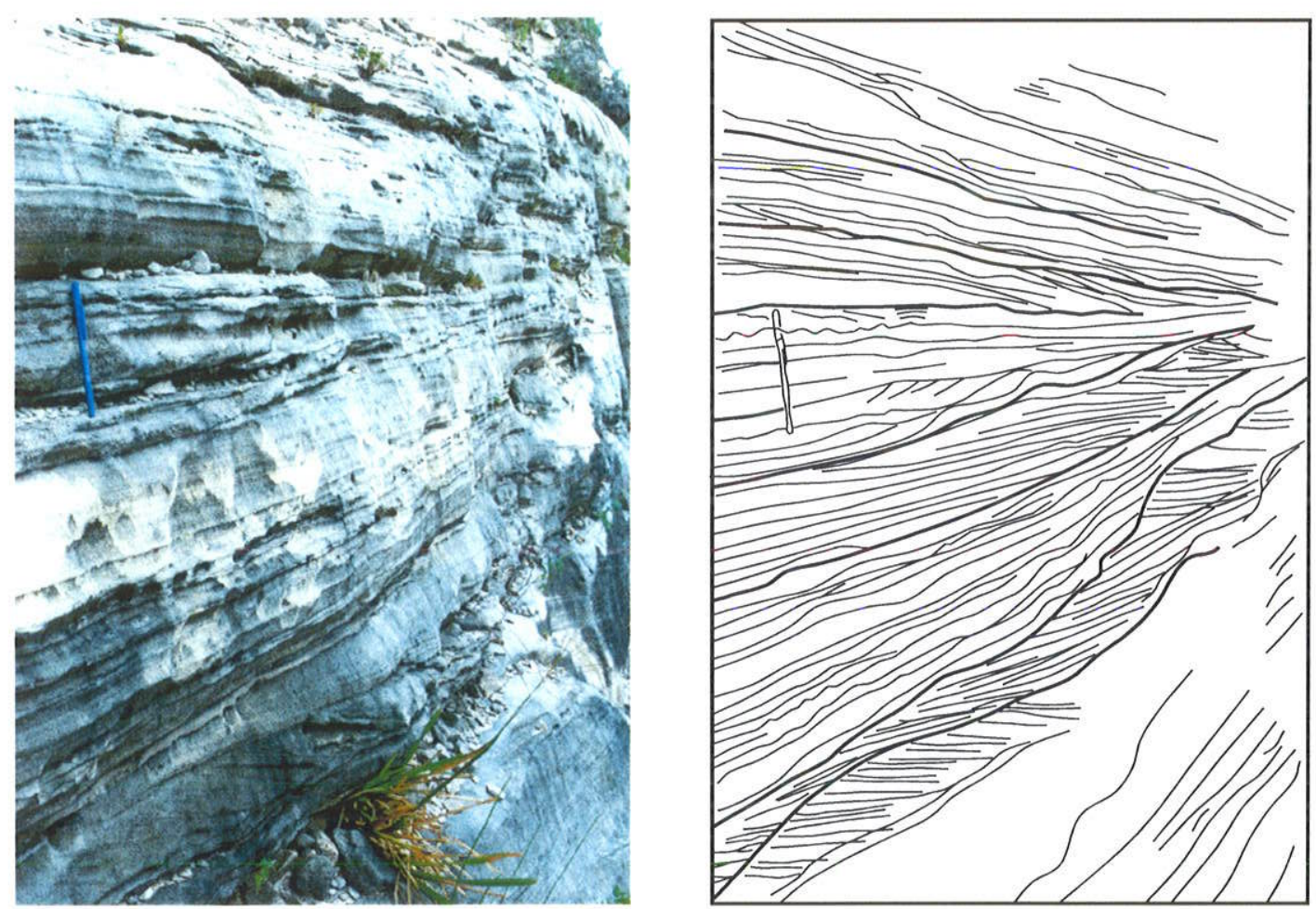

A. Arenito fino com laminações horizontal e cruzada de baixo ângulo (Pedreira Cristalito, pto Mu14).
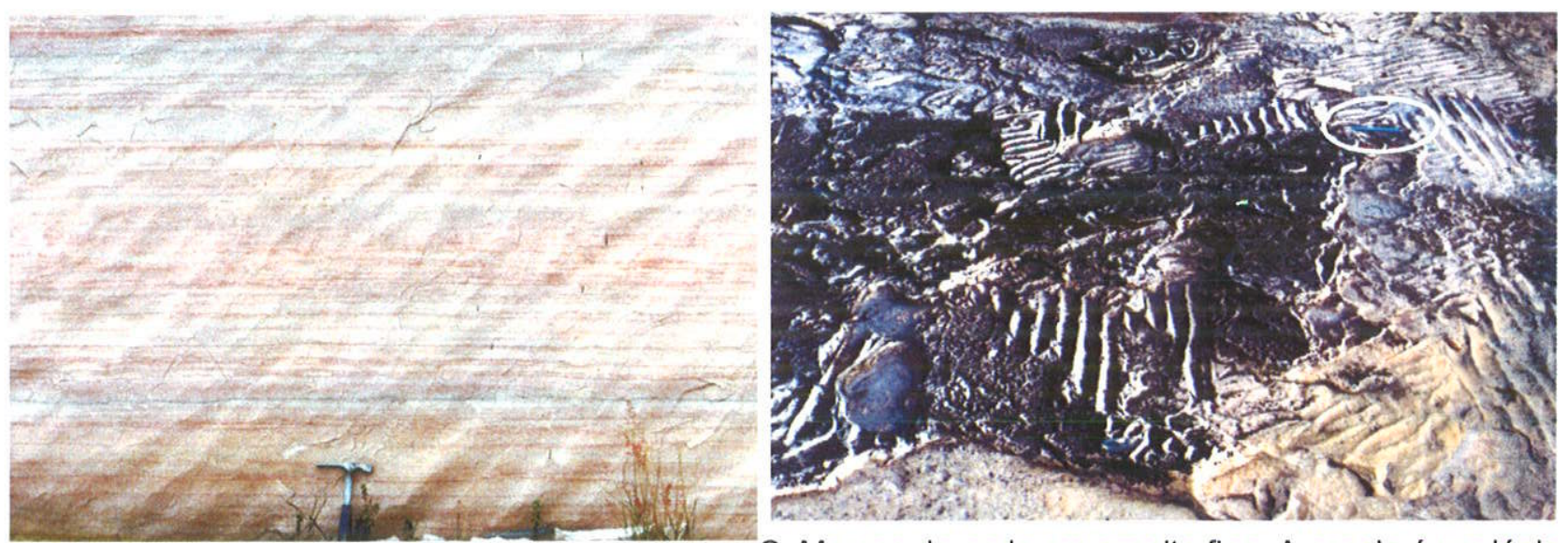

C. Marcas de onda em arenito fino. A escala é um lápis,

B. Arenito fino com laminação horizontal (Pedreira em destaque (Bar Mucugezinho - BR-242, pto Mu6). Cristalito).
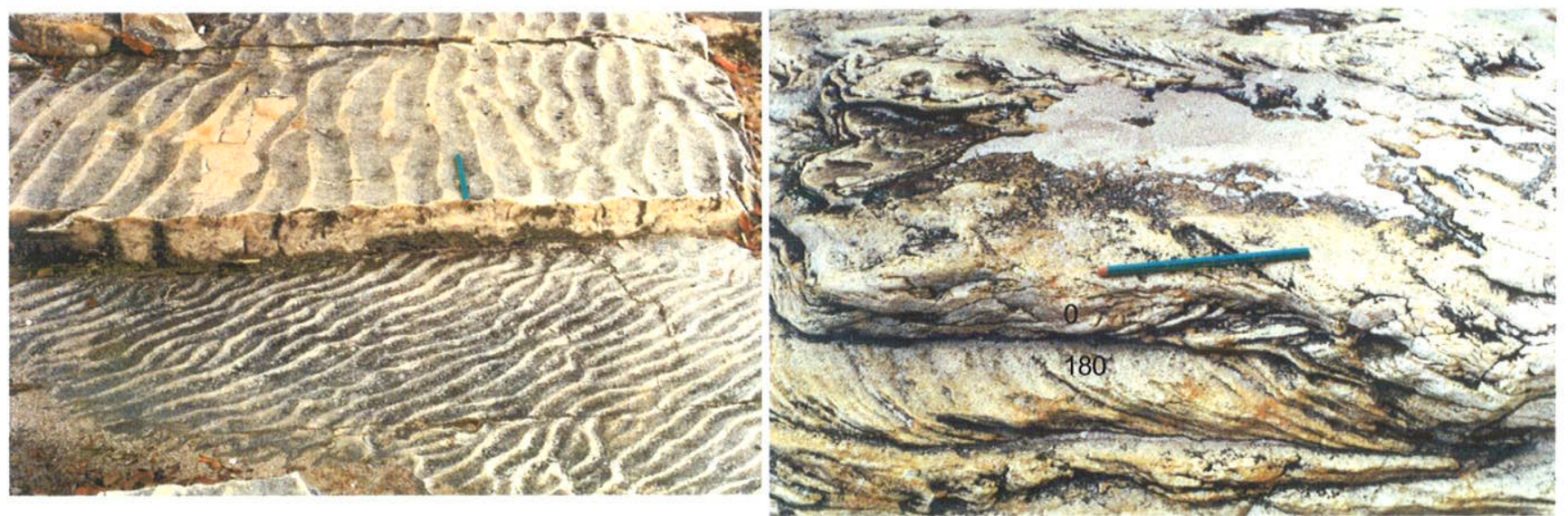

D. Arenito fino com marcas de onda. Passagem

E. Arenito médio com estratificação cruzada espinhapara a Formação Caboclo (foz do Rio Lapão, pto La9) de-peixe. Passagem para a Formação Caboclo (foz do Rio Lapão, pto La9). 
Figura V.10. Associação deltaica.

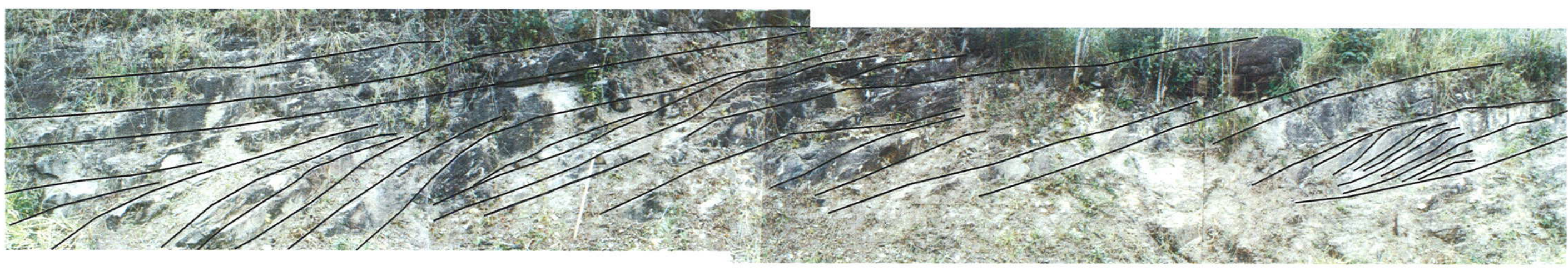

A. Progradação de arenito de barra de desembocadura (frente deltaica) com camadas frontais recobertas por camadas de topo (forsets, topsets). Escala, enxada com 1,2m.

Parte do perfil do Rio Mucugezinho BR-242 (Ponto Mu1A)

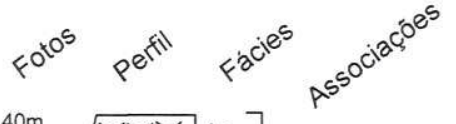

$$
\begin{aligned}
& \text { A B } \\
& \text { Deltaica }
\end{aligned}
$$

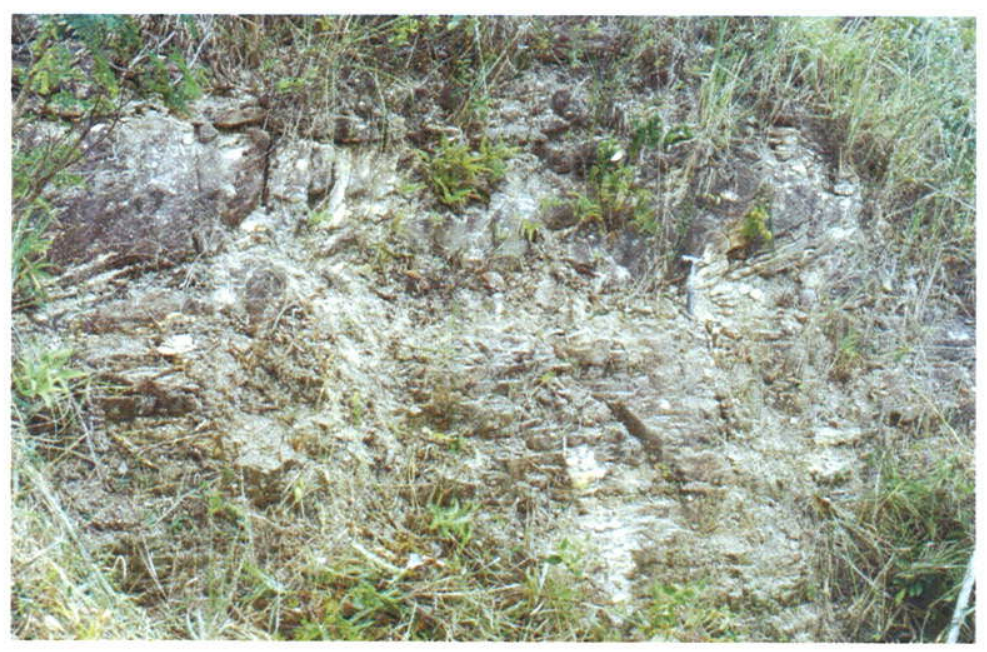

B. Detalhe da foto anterior.

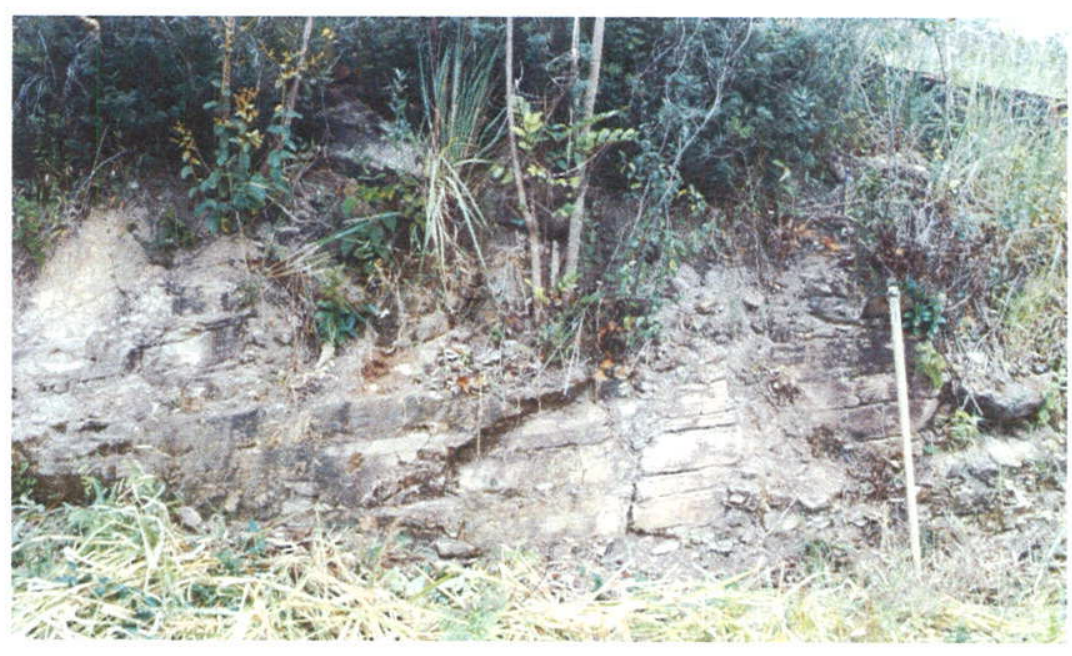

C. Estratos de arenito (escala, enxada de 1,2m) 
assentado diretamente em siltito marinho, e é recoberto por depósitos fluviais, conferindo ao conjunto um arranjo progradante (Fig. V.10).

Tal progradação de camadas de topo e frontais pode ser atribuída a um delta tipo Gibert, associado a águas rasas (Galloway 1975). Vale a pena ressaltar o sentido leste do avanço deltaico, o que contraria a tendência geral da Formação Tombador (transporte para oeste).

\section{FRENTE DELTAICA}

Unicamente observado junto ao Rio Capivara, no último ciclo do intervalo superior da Formação Tombador (Ponto Ca1), ocorrem ritmitos areno-sílticos que freqüentemente estão deformados (fácies $\mathbf{R}, \mathbf{R} \mathbf{c}$ ). A fácies rítmica consiste de camadas decimétricas de arenito e algum siltito intercalado, portando laminação cruzada por correntes (ripple drift crosslamination) ou por ondas, e contendo estruturas de carga e pilares arenosos (Fig. V.11-A); estas estruturas de carga apresentam concavidade voltada para cima e largura de aproximadamente $15 \mathrm{~cm}$, lembrando load ripples. Entre as estruturas de carga ocorrem os pilares arenosos, indicando escape de fluidos transportando areia (Figs. V.11-B, V.11-D). Na figura $\mathrm{V} .11-\mathrm{C}$, observa-se que os ritmitos deformados ocorrem intercalados em ritmitos nãodeformados.

O intervalo total de ritmitos apresenta espessura superior a $20 \mathrm{~m}$, e está interposto entre sedimentos flúvio-costeiros e fluviais (Fig. V.11). A referida associação se formou em um contexto de frente deltaica, provavelmente como deltas de crevasse. É sugerido que a grande quantidade de deformação, favorecida pela textura fina do arenito e siltito intercalado, tenha sido provocada por choques sísmicos.

\section{PLANÍCIE DELTAICA/MARINHA}

A associação planície deltaica é representada por espesso corpo (quase $10 \mathrm{~m}$ ) de arenito com estratificação cruzada acanalada e sigmóide, Aa e As, em sets unidirecionais com 0,5 a $1,0 \mathrm{~m}$ de espessura e paleocorrentes para WSW $\left(240^{\circ}\right)$ (Fig. V.12-A).

Tal corpo arenoso prograda sobre arenito e siltito da associação frente deltaica/marinha (Fig. V.12-B), sugerindo que aquele corpo localiza-se num contexto de planície deltaica. Esta interpretação é reforçada pelo fato do referido corpo arenoso ser recoberto por uma seção areno-conglomerática fluvial (ver Fig. V.6), completando assim um perfil regressivo marinhofrente deltaica-planície deltaica-fluvial, característico do último ciclo do intervalo superior da Formação Tombador, no Rio Ribeirão de Baixo (Ponto Ri1). 
Figura V.11. Associação de frente deltaica (delta de crevasse).

Parte do perfil do Rio Capivara

(Ponto Ca1)

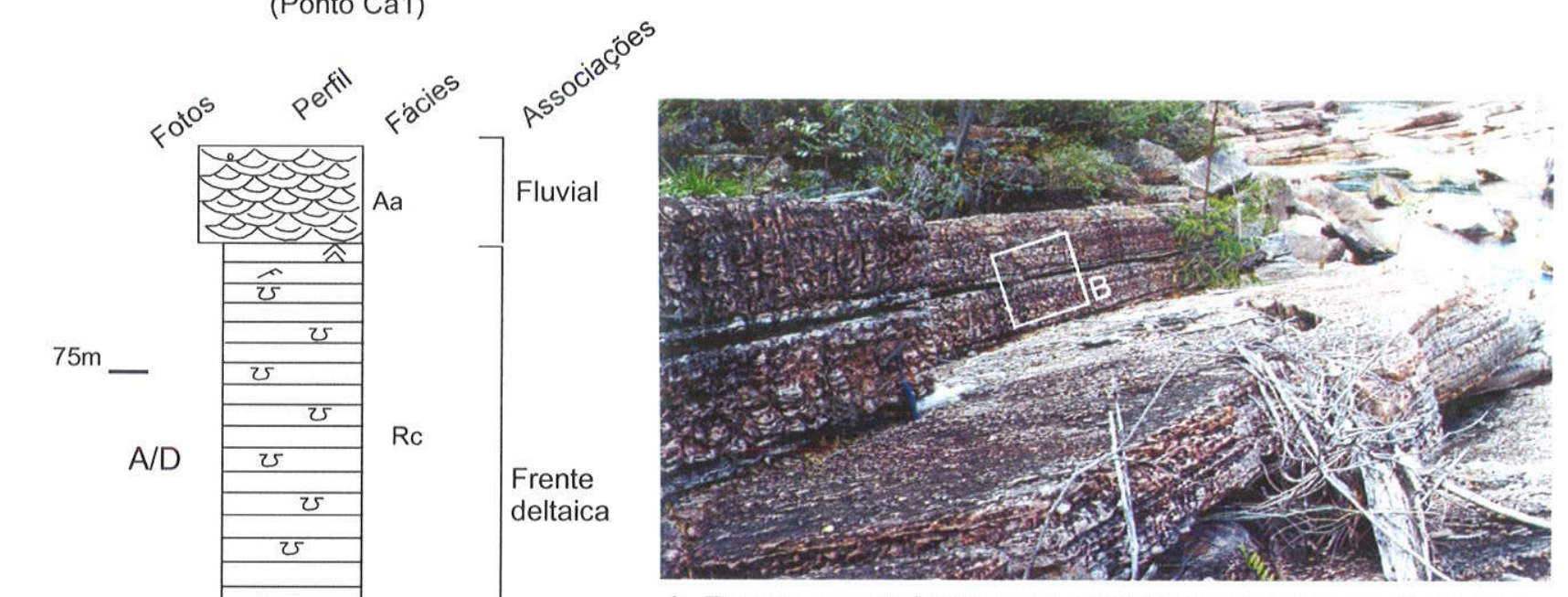

A. Ritmito arenito/siltito com estruturas em pilar e sobrecarga.

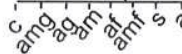
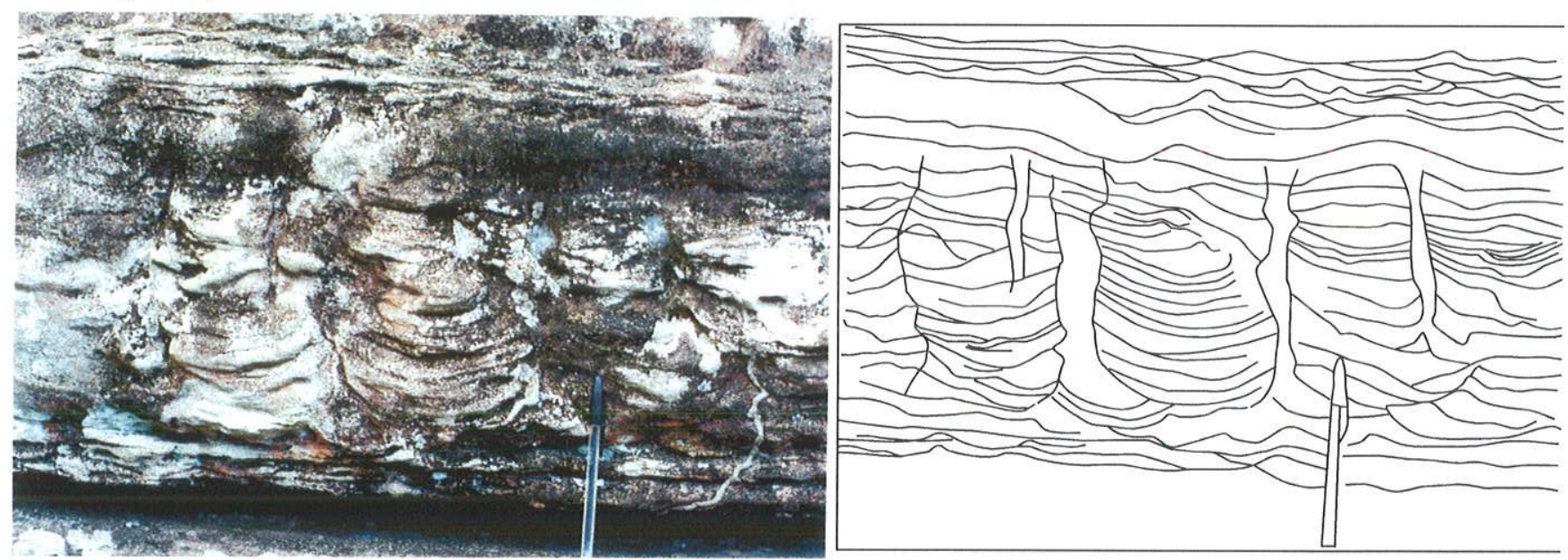

B. Detalhe da foto anterior: observar as estruturas de sobrecarga e pilares arenosos.

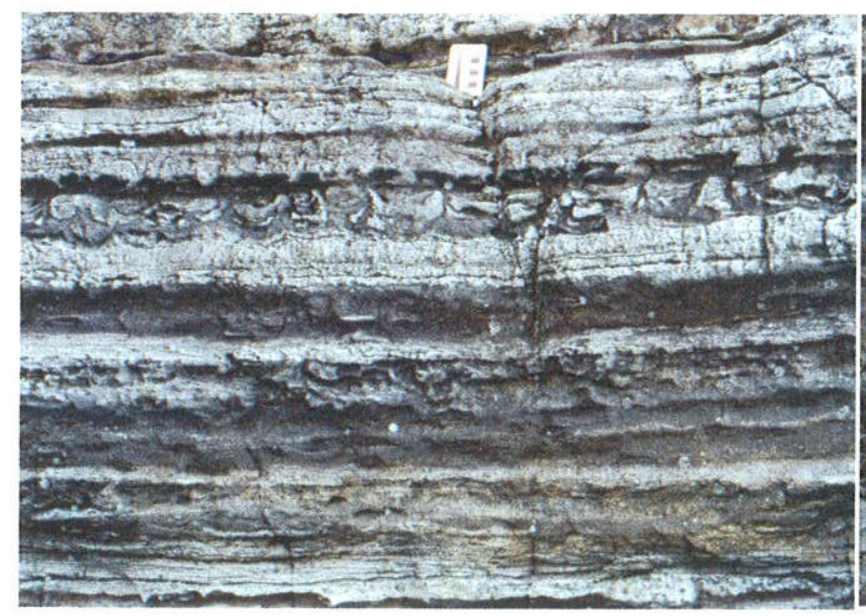

C. Níveis de ritmito não deformado com laminação horizontal e cruzada e deformado, com estruturas de sobrecarga.

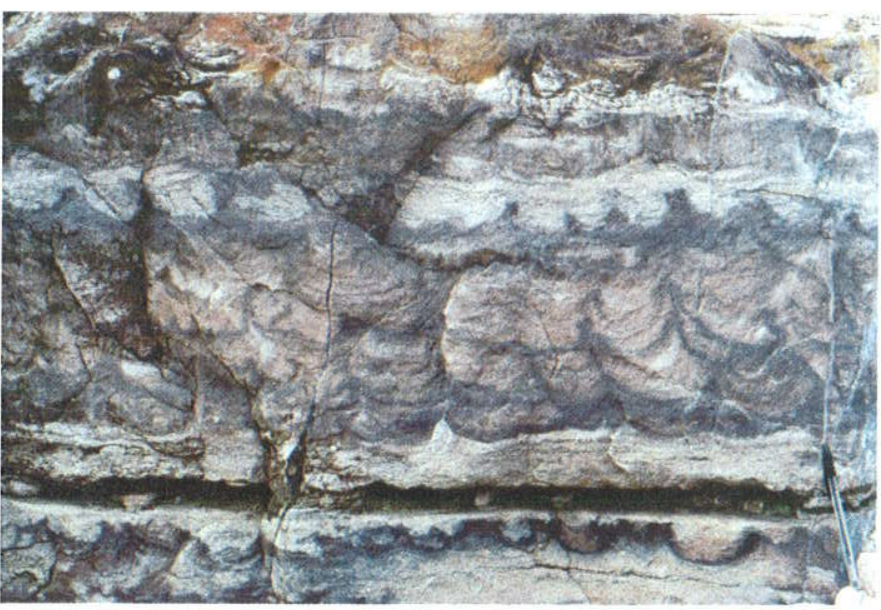

D. Ritmito deformado com estruturas de sobrecarga (possivelmente load ripples). 
Figura V.12. Associação planície deltaica/marinha.

Parte do perfil do Rio

Ribeirão de Baixo (Ri1)

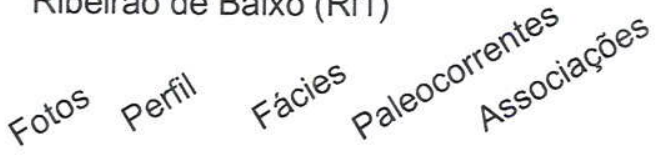
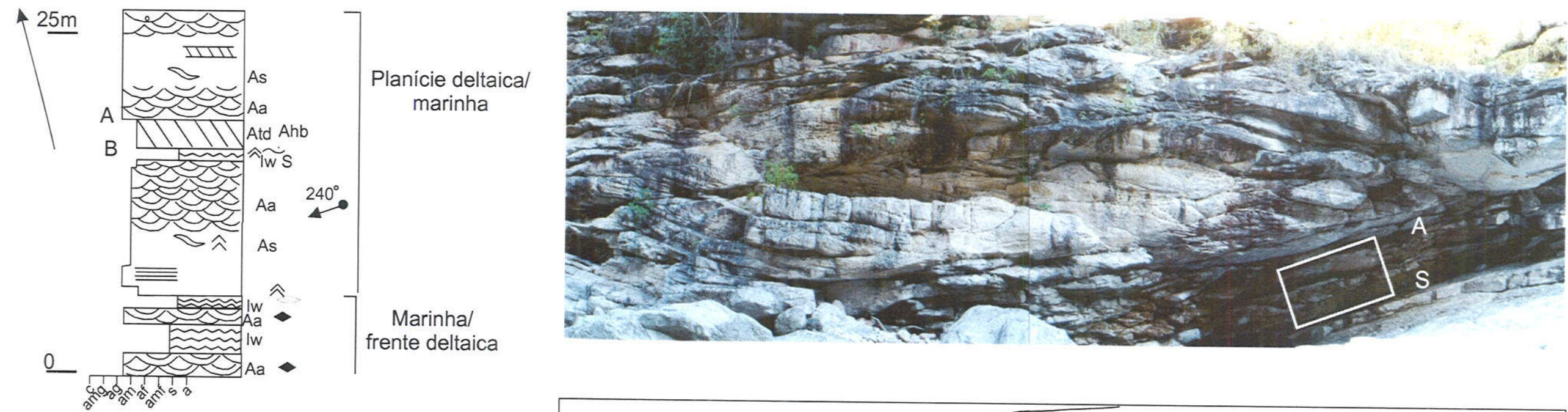

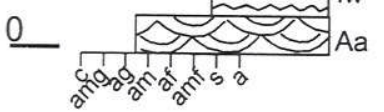
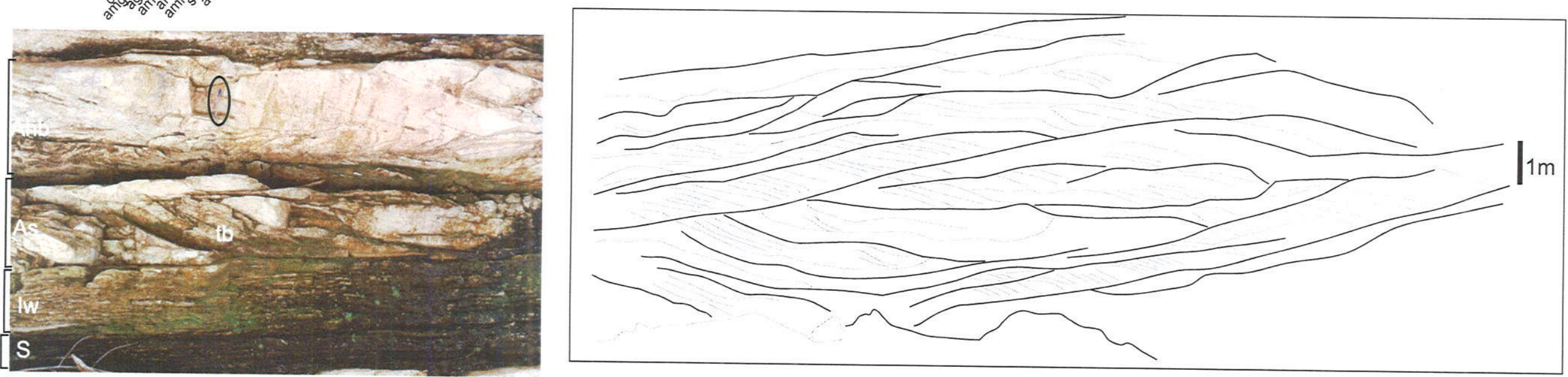

B. Sucessão ascendente de siltito $\mathbf{S}$, interlaminado Iw e

arenitos com estratificação sigmóide As (tidal bundles tb) A . Progradação de arenitos com estratificações cruzadas acanalada e sigmóide sobrepondo-se a arenito A e espinha-de-peixe Ahb. Em destaque, caneta como escala. 
A associação planície deltaica/marinha consiste de um perfil progradante de siltito e interlaminação wavy $(\mathbf{S}, \mathbf{I w})$ recoberto por arenito médio com estratificação cruzada tabular e sigmóide, com sets de 0,1 a 0,3m de espessura (As) (Fig. V.12-B); neste arenito se destacam superficies de reativação e feixes de marés (tidal bundles), e também estratificação cruzada espinha-de-peixe, Ahb, com paleocorrente dominante para $260^{\circ}$ (vazante, para oeste) e subordinada para $80^{\circ}$ (leste). Essas características sugerem um ambiente de planície deltaica influenciada por correntes de marés.

\section{MARINHA/FRENTE DELTAICA}

A associação marinha/frente deltaica é composta por duas fácies, sendo uma de arenitos com estratificação cruzada tabular e acanalada (frente deltaica), recobrindo a outra de arenitos e siltitos (tempestitos de ambiente marinho shoreface).

O conjunto está bem representado no perfil do Rio Ribeirão de Baixo, dentro do último ciclo do intervalo superior da Formação Tombador, onde se assenta transgressivamente sobre arenitos conglomeráticos fluviais. A fácies marinha é formada por tempestitos: arenitos finos a médios com estratificação ondulada truncante de grande e pequeno porte, fácies Ah (hummocky e microhummocky), que gradam a interlaminação (wavy) de arenito e siltito ou a siltito rítmico, fácies Iw e R (Fig. V.13-A). Pavimentos de seixos (pebbles), com 15 a $40 \mathrm{~cm}$ de espessura, ocorrem na base de siltitos e constituem lags transgressivos (Fig. V.13-B). Superficies portando marcas de onda são comuns no topo dos tempestitos: as cristas dispõese com duas orientações, a $80-105^{\circ}$ (aproximadamente leste-oeste) e a 170-180 (norte-sul) (Fig. V.13-C). Localmente foi observada uma superfície com prováveis bioturbações horizontais (Fig. V.13-D).

Sobrepondo-se abruptamente à associação marinha ocorrem corpos de arenito médio, de espessura métrica ( 1 a $2 \mathrm{~m}$ ), portando estratificação cruzada tabular em sets com 20 a $30 \mathrm{~cm}$ de espessura (fácies At, Aa; Fig. V.13-A); mais acima no perfil, tais arenitos são sucedidos por arenitos grossos, com estratificação cruzada acanalada e clastos argilosos. As paleocorrentes indicam transporte para sudoeste $\left(210^{\circ}\right.$ a $\left.235^{\circ}\right)$. No perfil do Rio Ribeirão de Baixo ocorrem pelo menos cinco ciclos, de granocrescência ascendente, com arenitos médios/grossos (At, $\mathbf{A a}$ ), interpretados como de frente deltaica, progradando sobre arenitos e siltitos marinhos (Ah, Iw, S).

A referida sucessão "granocrescente" volta a correr mais acima no perfil do Rio Ribeirão, só que agora exibindo feições diagnósticas de marés nos arenitos de frente deltaica, como estratificação cruzada espinha-de-peixe, superfícies de reativação e feixes de marés- 
Figura V.13. Associação marinha/frente deltaica.

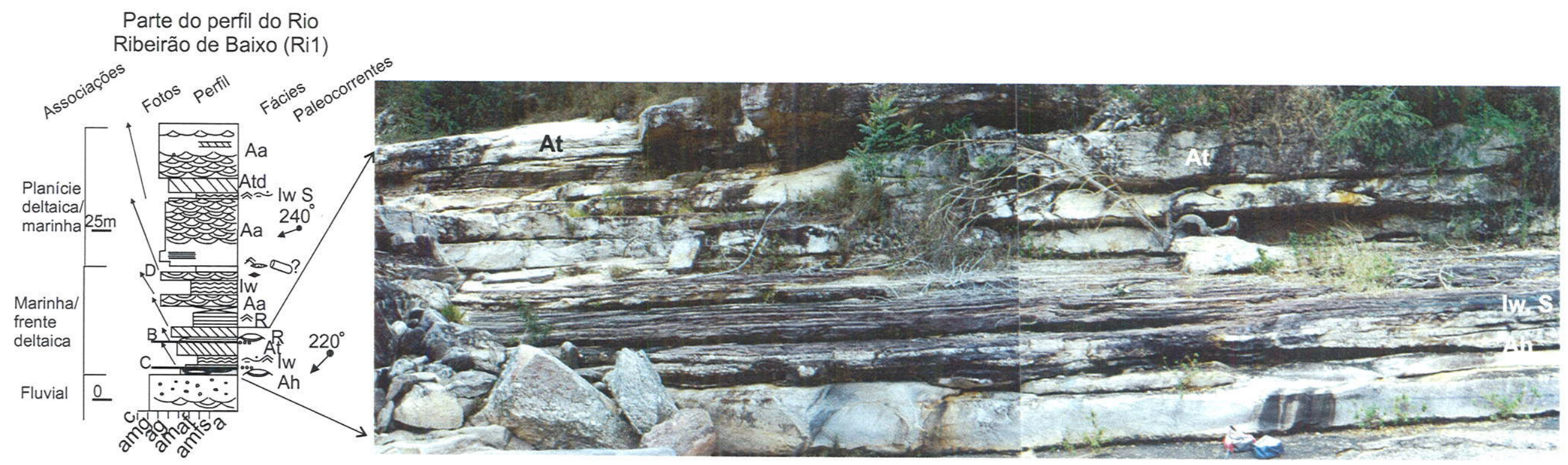

A. Arenito com estratificação ondulada truncante $\mathbf{A}$, interlaminado Iw e siltito $\mathbf{S}$, intercalados com arenito com estratificação cruzada tabular At.

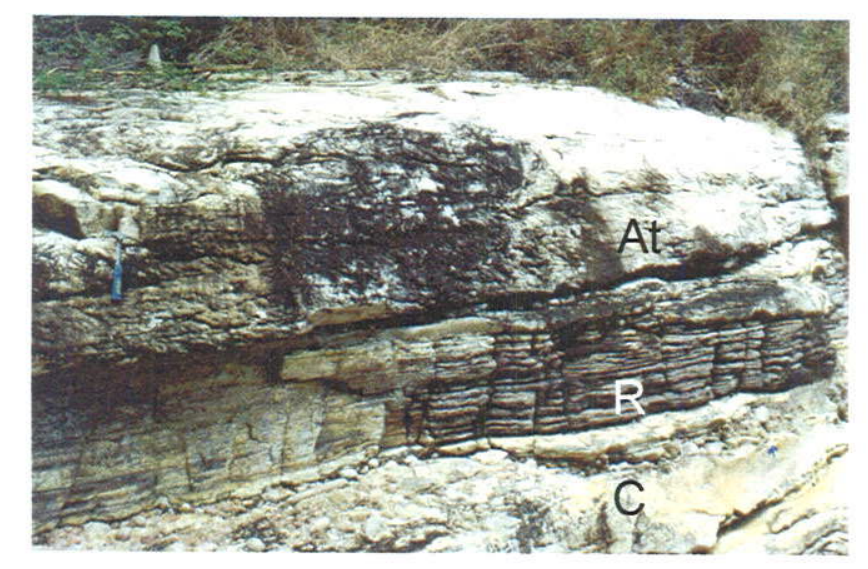

B. Lag transgressivo de conglomerado C, sobreposto por ritmito $\mathbf{R}$ e arenito com estratificação cruzada tabular At.

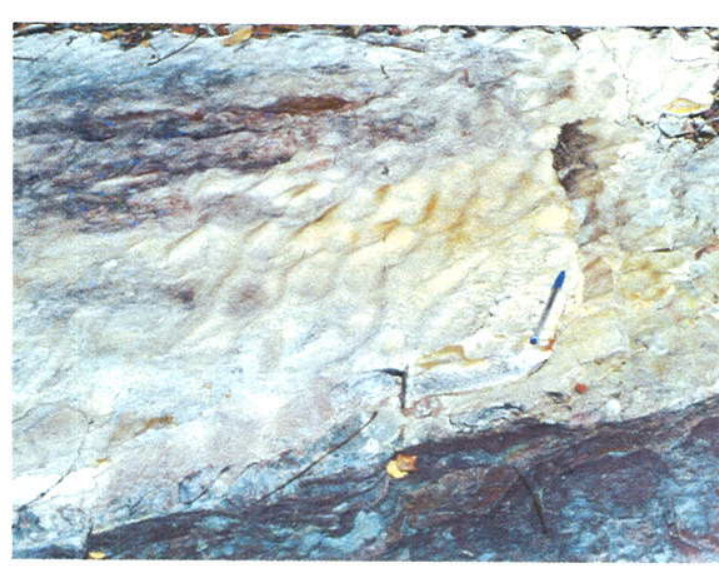

C. Pavimento com marcas de onda no topo de tempestitos. Cristas orientadas $80^{\circ}, 105^{\circ} \mathrm{e} 175^{\circ}$.

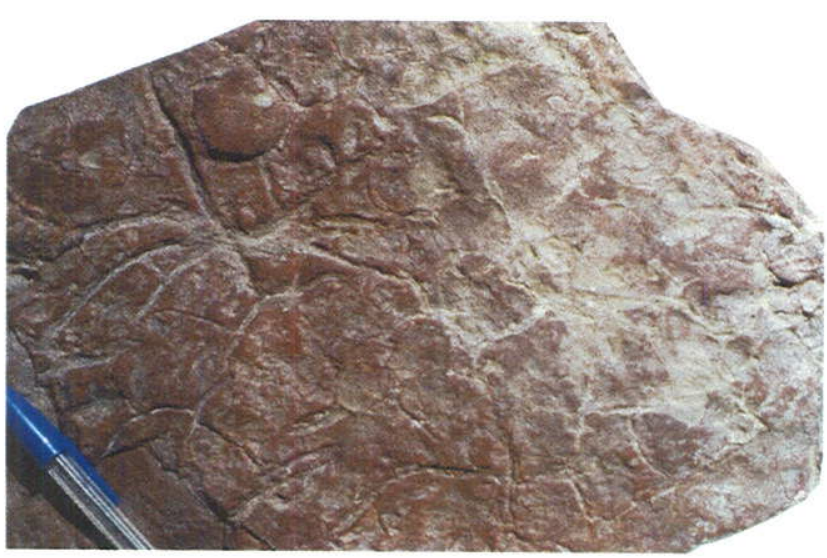

D. Possível bioturbação horizontal. 
(tidal bundles; ver Fig. V-12-B); neste caso, a sucessão é recoberta por depósitos de planicie deltaica.

\section{ESTUARINA MARINHA}

No perfil do Rio Ribeirão de Cima, ponto Ri9, a associação consiste de duas fácies, arenitos de canal e arenitos e siltitos marinhos de tempestades interposta entre depósitos flúvio-estuarinos.

Ocorrem pelo menos duas sucessões granodecrescentes, com arenitos de canal passando a arenitos e siltitos marinhos. A fácies de arenito de canal apresenta estratificação cruzada acanalada e sigmóide, com superfícies retrabalhadas por ondas, estratificação espinha-de-peixe (Ahb) e drapes/megaflasers sílticos entre os estratos arenosos (Fig. V.14-A, B).

A fácies de arenitos finos/médios e siltitos ocorre sobreposta a de canal, e é recortada pelo canal seguinte (Fig. V.14-A). Os arenitos exibem estratificação ondulada truncante ( hummocky, microhummocky) e gradam a siltitos (Fig. V.14-C).

Essa organização granodecrescente das duas fácies sugere um contexto transgressivo, com depósitos tracionais de preenchimento de canal gradando a tempestitos marinhos. A presença de feições de maré retrabalhando os estratos arenosos, junto ao contexto transgressivo, suporta uma origem estuarina para os referidos canais. Além da medida principal de paleocorrentes para sudoeste, outras medidas apontam sentidos quase opostos como Norte-noroeste e Sul.

Esta associação é observada também no corte da rodovia $\mathrm{BR}-242$ próximo à ponte do Rio Mucugezinho (Ponto Mu-10), e consiste de um perfil, com 30m de espessura, de arenitos intercalados com siltitos (Fig. V.15).

Os corpos de arenito alcançam poucos metros de espessura, e são formados de estratos cruzados acanalados, tabulares e sigmoidais, Aa, At e As (Fig. V.15-C, V.15-D); estes últimos alcançam alturas/espessuras de até dois metros, preenchendo feições de canal (Fig. V.15-E).

Os corpos de "siltito" podem ser representados por siltitos ou por delgados ritmitos de arenito fino com laminação cruzada clino-ascendente gradando a siltito, $\mathbf{R}$ e Ar (Figs. V.15-A, V.15-B).

A fácies de arenito é normalmente recoberta pela de siltito, em um arranjo granodecrescente. Uma boa evidência disto é a presença, entre as duas fácies, de arenitos com estratificação cruzada e numerosas superfícies de reativação marinha, onde ocorrem 
Figura V.14. Associação estuarina-marinha (Rio Ribeirão).
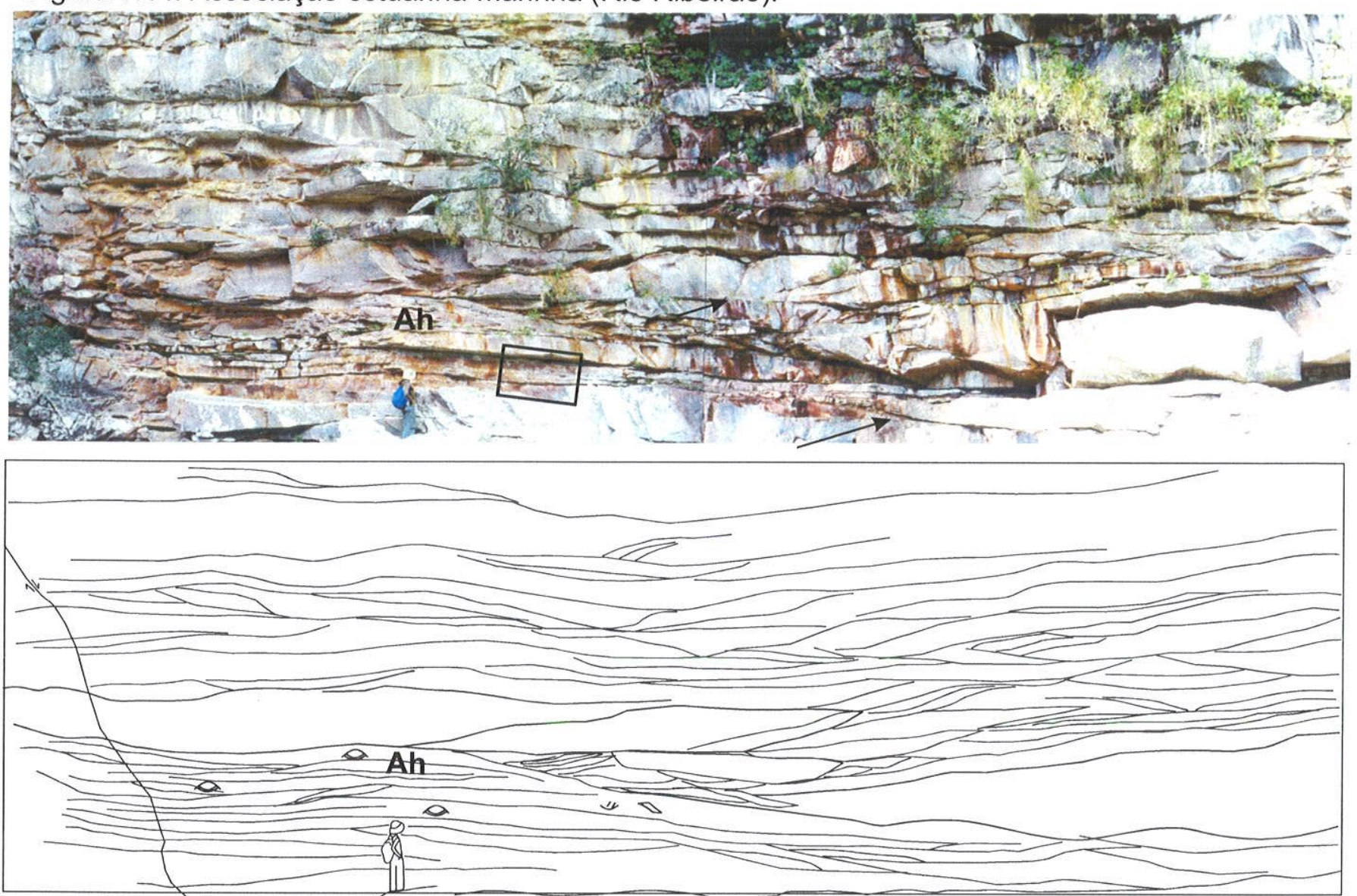

A. Arenitos com estratificações cruzada acanalada e sigmóide preenchendo canais (seta). Notar intercalação de arenitos e siltitos (tempestitos $\mathbf{A h}$ ).

Parte do perfil do

Rio Ribeirão (Ri9)
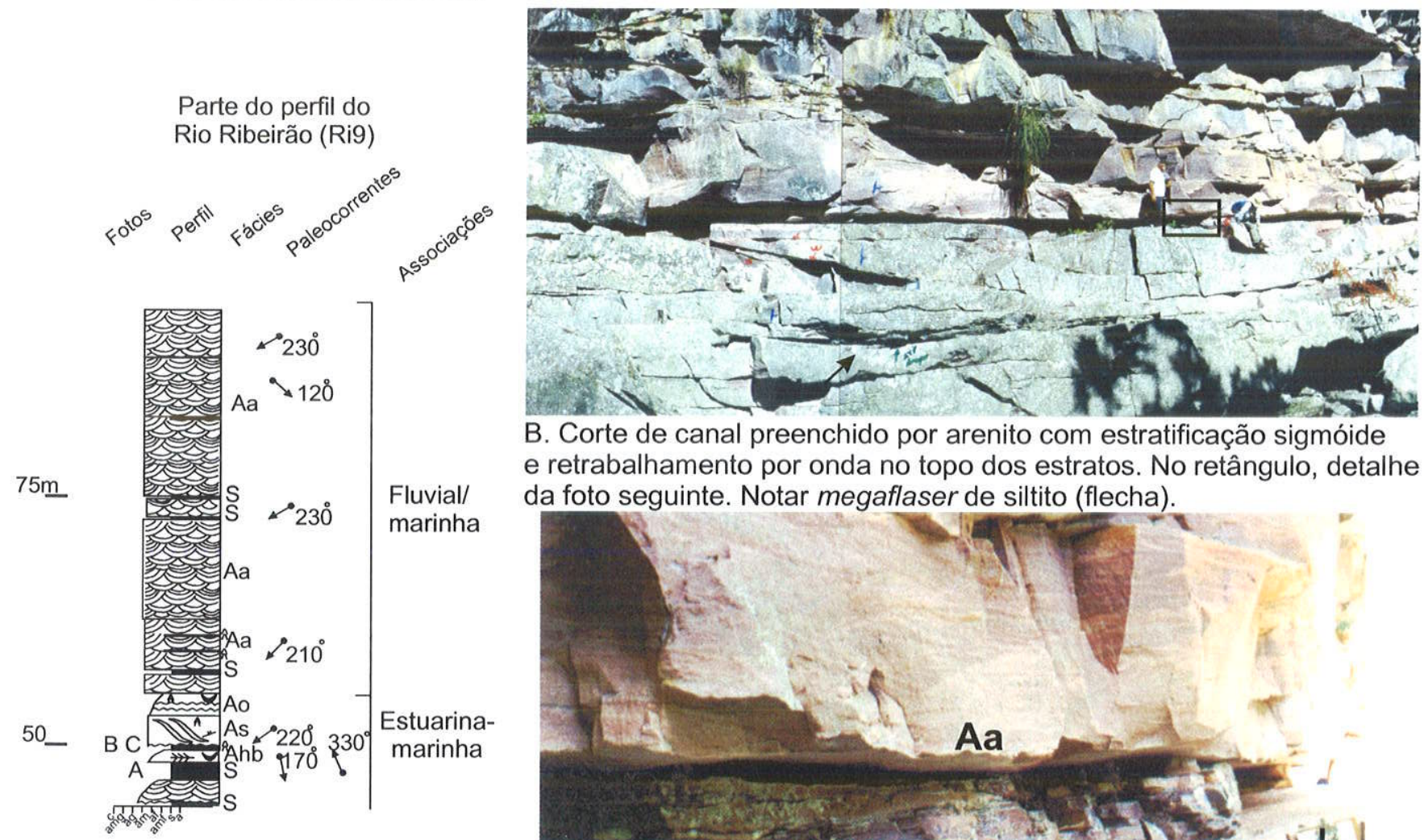

B. Corte de canal preenchido por arenito com estratificação sigmóide e retrabalhamento por onda no topo dos estratos. No retângulo, detalhe da foto seguinte. Notar megaflaser de siltito (flecha).

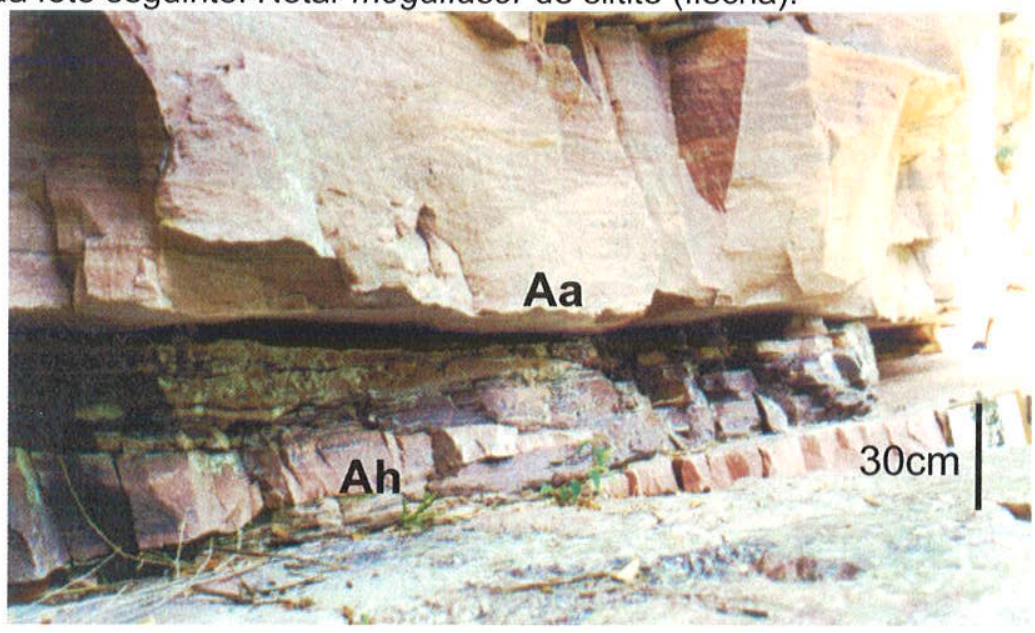

C. Detalhe da foto B. Arenito com estratificação ondulada truncante Ah e siltito sobrepostos abruptamente por arenito grosso com estratificações cruzadas acanalada Aa e sigmóide. 
Figura V.15. Associação estuarina-marinha (BR-242).
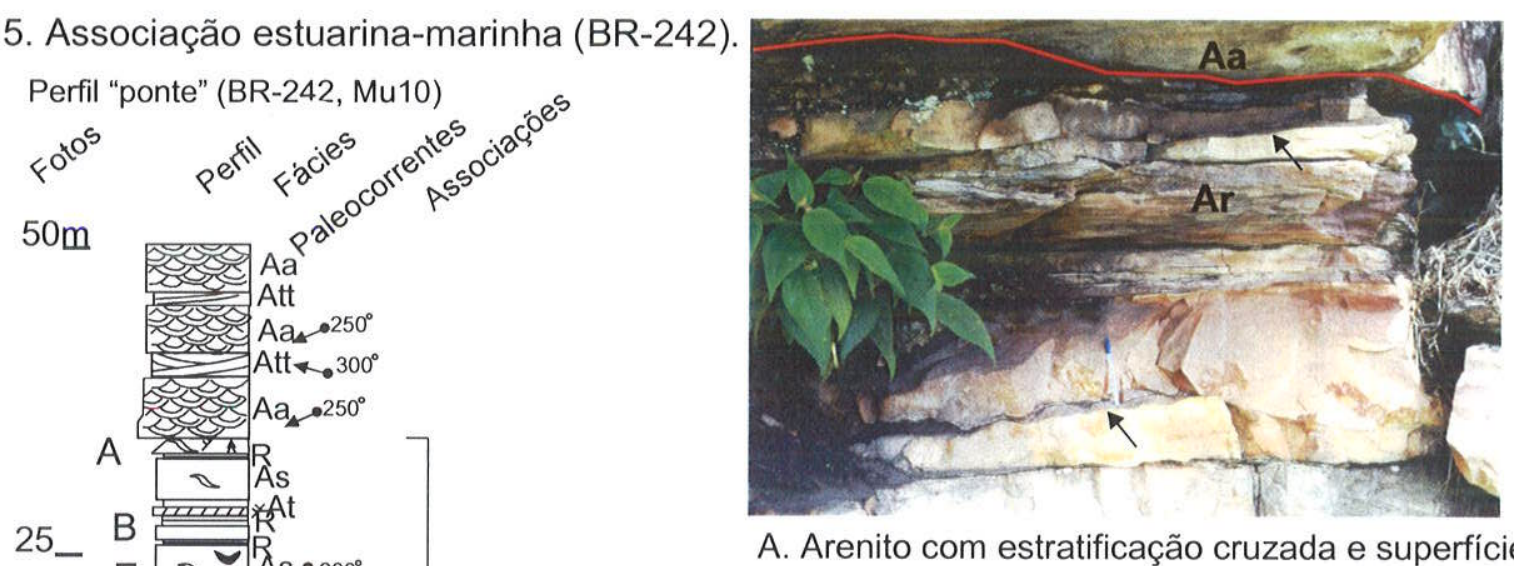

$\begin{array}{lll}E \text { As } \varphi^{200^{\circ}} & \text { Estuarina- } \\ \text { marinha } & \end{array}$

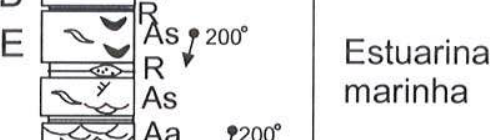

0

A. Arenito com estratificação cruzada e superfícies de retrabalhamento marinho (flechas), intercalado com arenito com laminação cruzada Ar. Notar acima arenito grosso $\mathrm{Aa}$ com base acanalada.

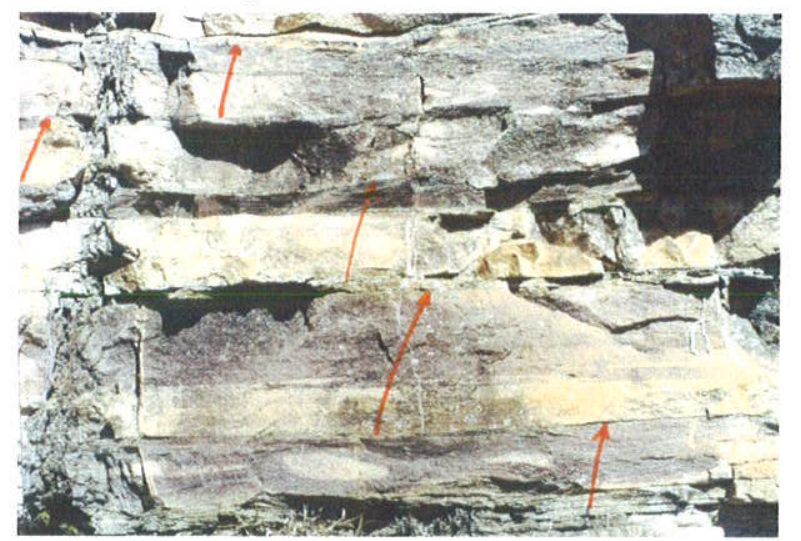

B. Cinco ritmitos arenito/siltito com granodecrescência ascendente (flechas). Altura da foto $=0,8 \mathrm{~m}$.

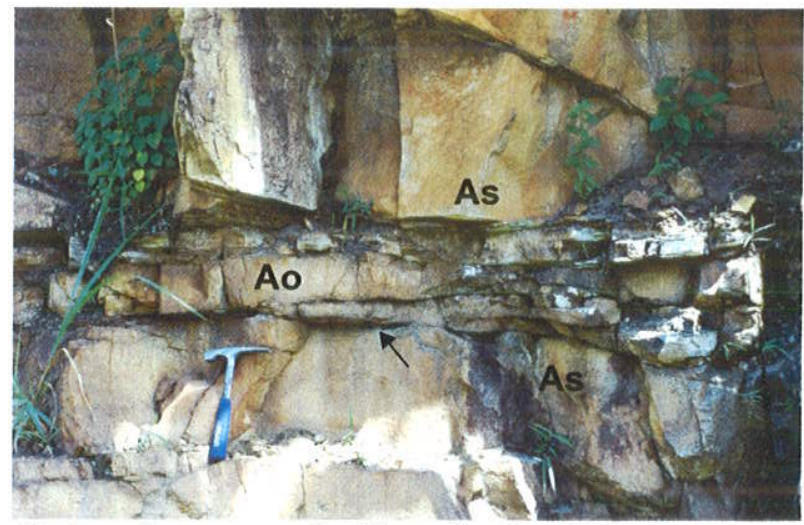

D. Arenitos com estratificação sigmóide As intercalados com arenitos retrabalhados por onda Ao.

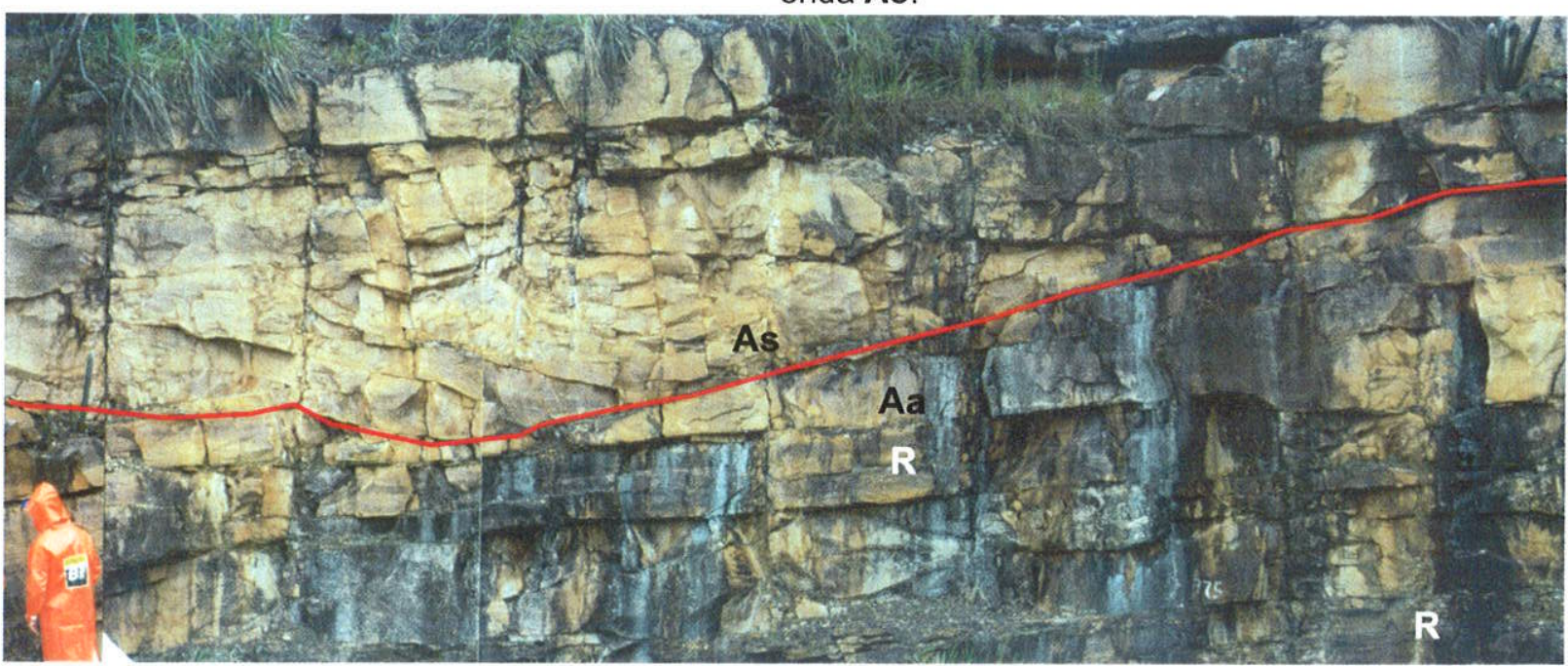

E. Arenito com estratificação sigmóide As preenchendo canal, sobreposto a ritmito $\mathbf{R}$ e arenito Aa. 57 
drapes e flasers de siltito (Figs. V.15-A, -D). Alguns desses arenitos "transicionais" mostram laminações onduladas sugestivas de estratificação hummocky, Ah.

Assim, a sucessão granodecrescente de arenito sigmoidal de canal passando a arenito com drapes/flasers de siltito, sugere um contexto de canal distributário-estuário (?). Os ritmitos areno-sílticos, como depósitos de suspensão, indicam um contexto deltaico. As paleocorrentes são mais constantes, seguindo a orientação geral para sudoeste (entre $200^{\circ}$ e $250^{\circ}$ ). Aqui é pertinente comparar a sucessão acima com a associação anterior, exposta no Ribeirão de Cima (Fig. V.14): apesar da semelhança da organização seqüencial, aqui as paleocorrentes são mais variáveis e não foram notadas as fácies de suspensão (Ar, R).

\section{ESTUARINA DISTAL/MARINHA}

O afloramento "mengão" da BR-242 (Ponto Mu22), com 17m de espessura, consiste de arenitos intercalados com siltitos/ritmitos finos, ambos apresentando uma geometria tabular. $O$ arenito mostra estratificação cruzada acanalada e sigmoidal (fácies Aa, As), às vezes modificadas por ondas (Figs. V.16-A, -D). Pequenos ciclos com granocrescência ascendente podem ser formados por arenitos com laminação cruzada e estratificação cruzada tabular (Fig. V.16-E). O siltito ou ritmito fino mostra lentes e delgados estratos arenosos com laminação cruzada clino-ascendente ou cruzada por ondas, sugerindo às vezes tempestitos delgados (Figs. V.16-A, V.16-D).

O afloramento "mengão", quando visto em um afloramento natural ao lado da rodovia (diferente do corte dinamitado), apresenta um aspecto semelhante ao das barras de marés do Perfil do Morro do Pai Inácio (ver Fig. V.17), sugerindo uma origem similar. O afloramento do Pai Inácio é considerado crono-eqüivalente, mergulho abaixo (e topograficamente acima), do afloramento "mengão".

A associação estuarina distal/marinha também está bem exemplificada no perfil levantado na subida da trilha que conduz ao topo do Morro do Pai Inácio (Ponto Mu13). Com cerca de $30 \mathrm{~m}$, consiste de arenitos grossos com estratificação cruzada acanalada, fácies $\mathbf{A a}$, intercalados com arenitos e siltitos marinhos. Esta última fácies é bastante característica, ocorrendo em três pontos do perfil superior (Fig. V.17). Cada estrato de arenito grada ou passa abruptamente a uma camada de siltito, no primeiro caso formando conjunto com granodecrescência ascendente. Três desses conjuntos são mostrados na figura V.17-A, notando-se que o "arenito" do conjunto inferior é composto de três estratos amalgamados; nesses arenitos ocorrem estratificações cruzadas tabulares, sigmóides e acanaladas (fácies At, As, Aa), e localmente superfícies de reativação com laminação cruzada por ondas e flaser, e feixes de marés (tidal bundles) (Figs. V.17-B, V.17-D). Os "siltitos", fácies S, incluem arenitos 
Figura V.16. Associação estuarina distal/marinha.

Parte do perfil do Rio Mucugezinho "mengão" - BR-242 (Mu22)
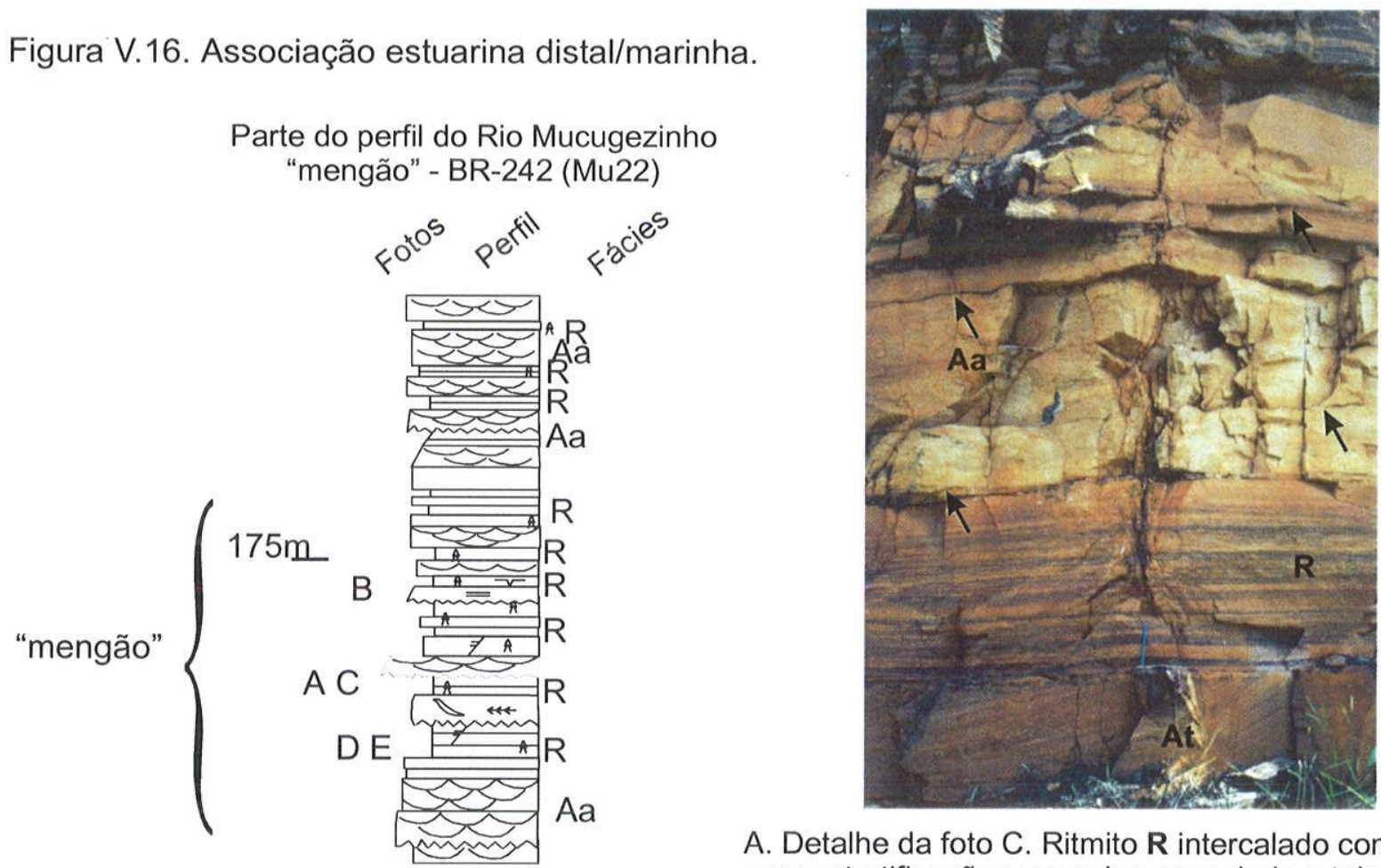

A. Detalhe da foto $\mathbf{C}$. Ritmito $\mathbf{R}$ intercalado com arenito com estratificações cruzadas acanalada e tabular Aa e

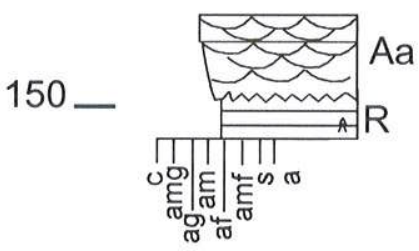
At. Notar superfícies retrabalhadas por ondas (flechas).
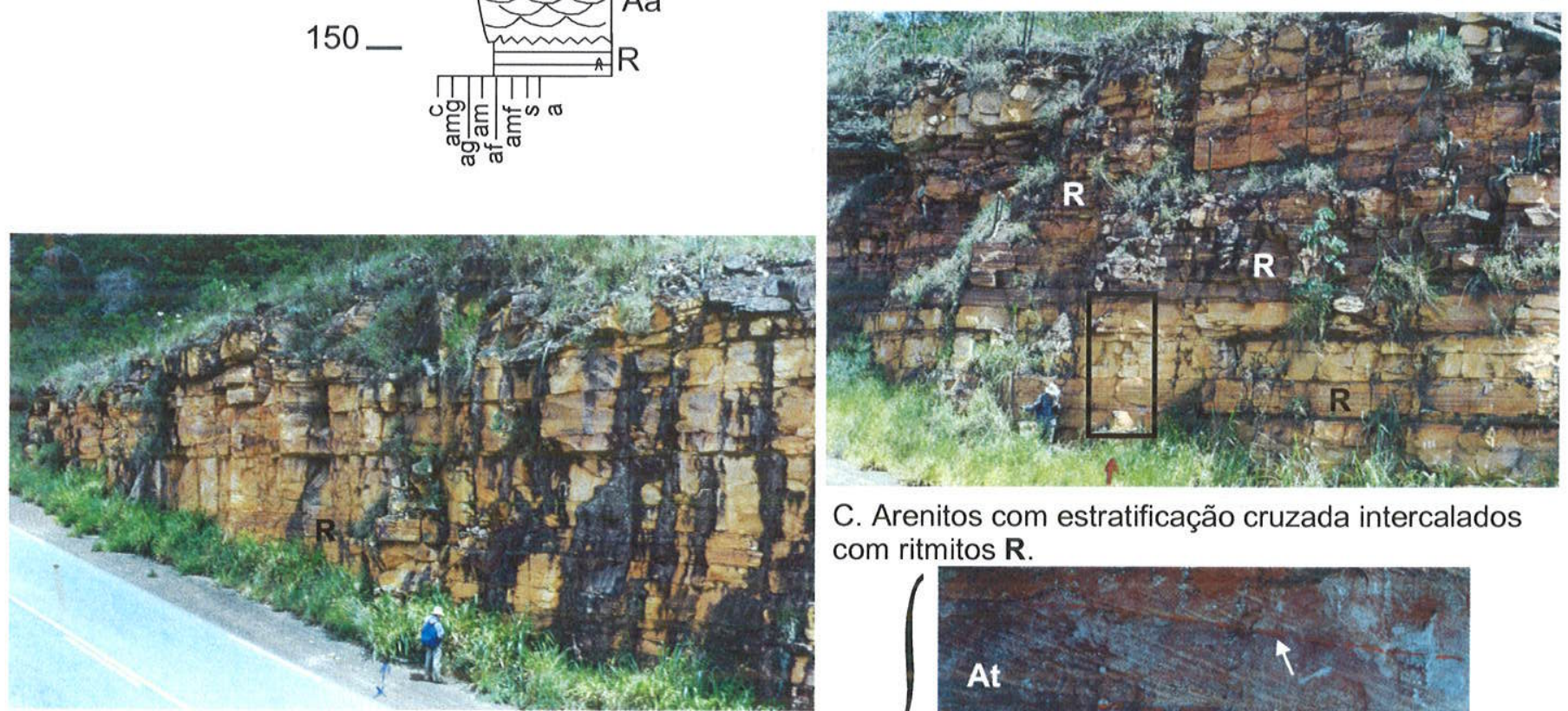

C. Arenitos com estratificação cruzada intercalados com ritmitos $\mathbf{R}$.

B. Arenitos com estratificação cruzada intercalados com ritmitos $\mathbf{R}$.

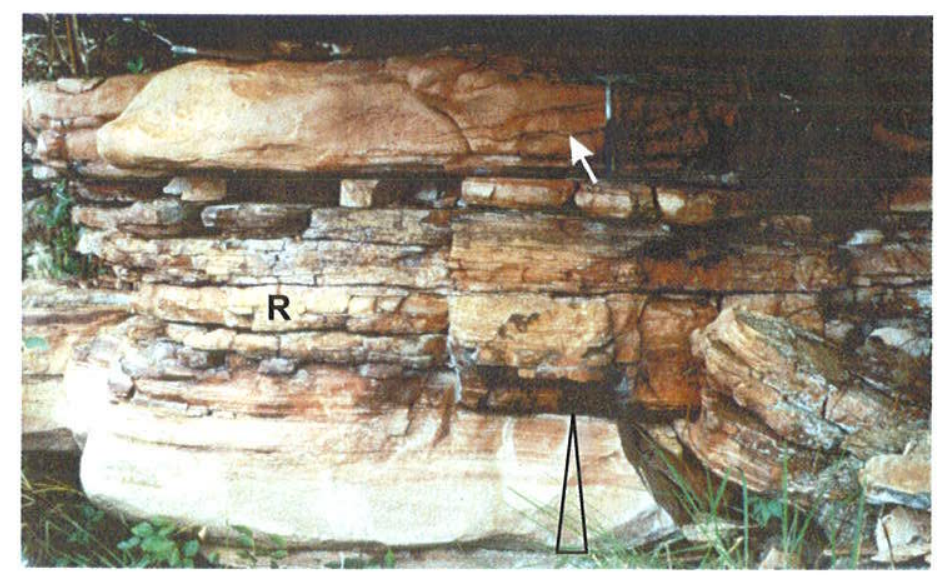

D. Arenito com aleitamento gradacional (\) sobreposto por ritmito $\mathbf{R}$ e por arenito com estratificação cruzada modificada por onda (flecha).

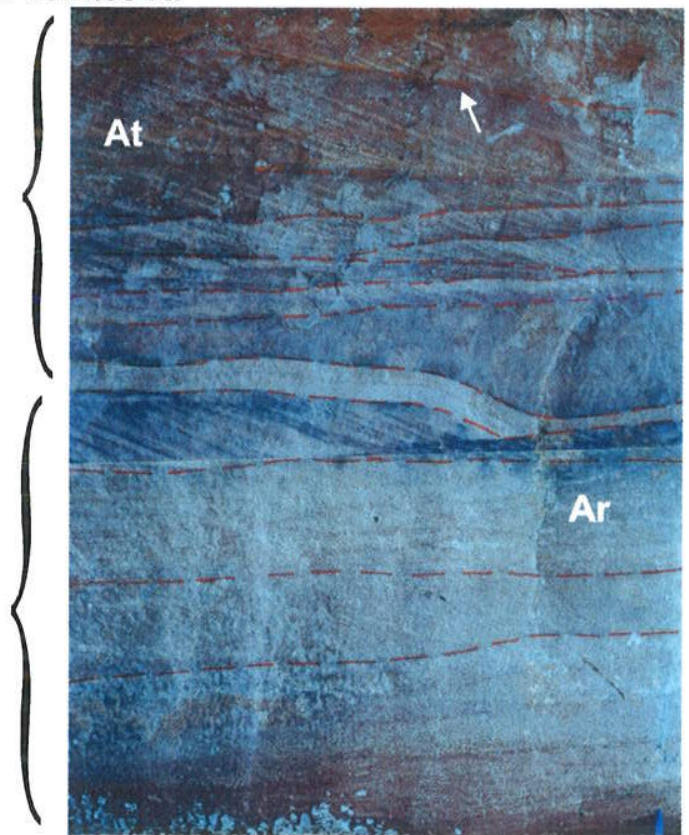

E. Dois sets de arenito com laminação cruzada $\mathrm{Ar}$ recoberto por arenito com estratificação cruzada tabular At; observar superfície de reativação (flecha). Altura da foto $=1$ metro. 
Figura V.17. Associação estuarina distal/marinha, trilha do Morro do Pai Inácio.

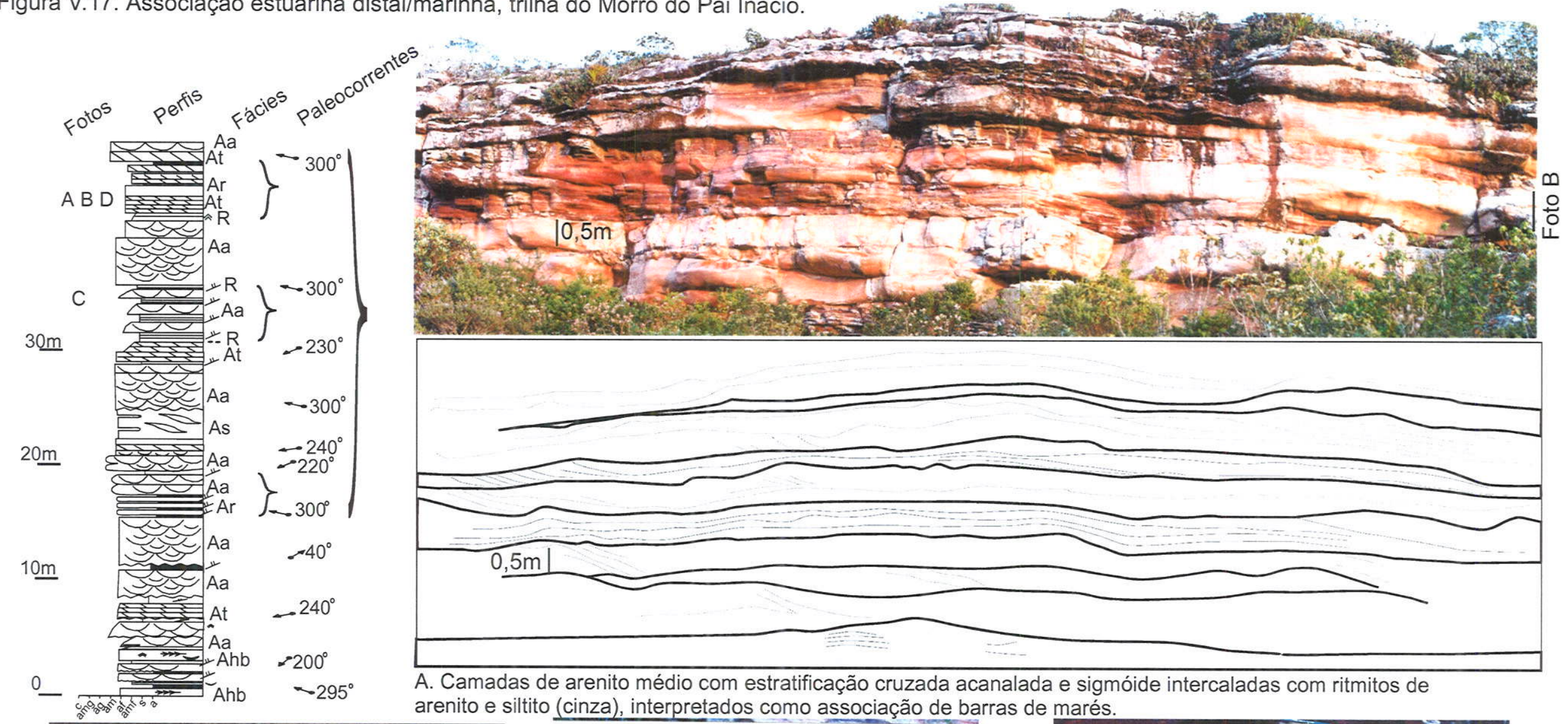

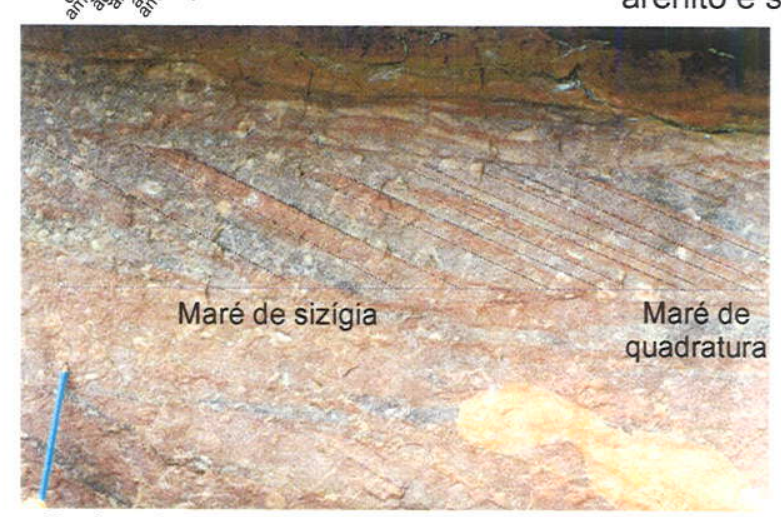

B. Arenito com tidal bundle.

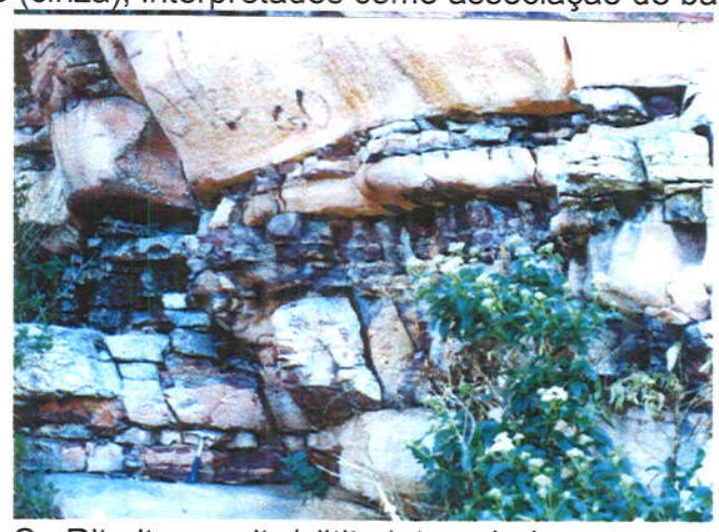

C. Ritmito arenito/siltito intercalado com arenito com estratificação cruzada.

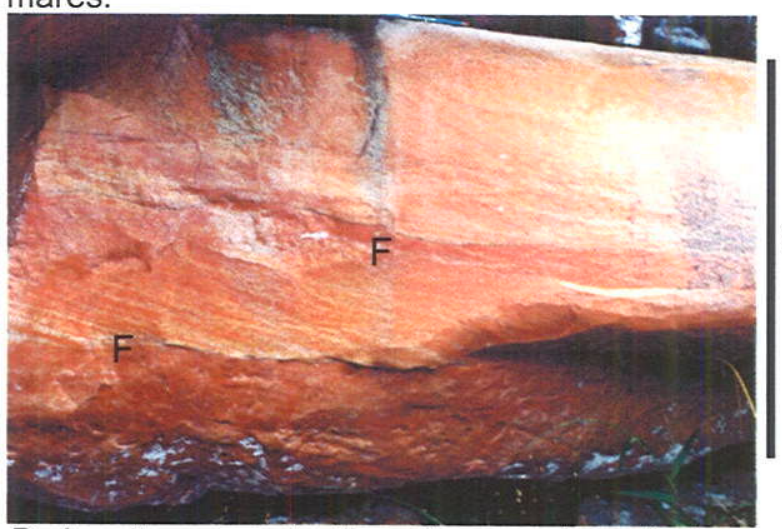

D. Arenito com estratificação cruzada e níveis de flaser $\mathbf{F}$. 
finos com laminação cruzada clino-ascendente, e às vezes um aspecto rítmico (fácies $R$ ), com pares arenito-siltito com provável estratificação ondulada truncante e aleitamento gradacional, e geometria compensatória (onde um par adelgaça o seguinte se espessa, e vice-versa) (Fig. V.17-C). Tais arenitos e siltitos exibem características marinhas de barra de marés ou de barra de foz de estuário (estuarine mouth bar - Dalrymple 1992).

As paleocorrentes medidas variam entre $210^{\circ}$ e $340^{\circ}$, aproximadamente para sudoeste e noroeste.

Tais intervalos descritos na subida do Morro do Pai Inácio configuram um padrão transgressivo, sobrepondo-se aos depósitos fluviais, em contraste com o padrão regressivo exibido pelas associações deltaica/marinha e fluvial costeira dos afloramentos "mengão" e "portal", na BR-242.

\section{MARINHA (BARRAS DE MARÉS)}

Esta associação é característica do intervalo inferior da Formação Tombador, no perfil ao sul do Morro do Pai Inácio, onde ocorrem aproximadamente $100 \mathrm{~m}$ de espessura de arenitos e siltitos marinhos. Tal conjunto consiste de quatro fácies distintas: (a) arenitos tabulares/amalgamados, (b) arenitos tabulares bifurcando-se em arenitos e siltitos delgados/lenticulares, (c) estratos de arenito gradando a siltito, e (d) ritmitos areno-argilosos e siltitos.

Os arenitos tabulares/amalgamados formam estratos espessos, de escala métrica, onde se observa estratificação cruzada tabular, sigmóide e acanalada, e raramente laminação horizontal, com freqüentes superfícies de reativação marcadas por laminação cruzada por ondas e drapes/flasers argilosos; nesta fácies também se notam "canais" preenchidos assimetricamente por estratos tabulares e heterolíticos, ou seja, foresets com lâminas arenosas e sílticas alternadas segundo feixes de marés (tidal bundles) (Figs. V.18-C, V.18-D). Os arenitos tabulares também podem apresentar gradação a estratos menos espessos, e eventualmente "catenárias" de siltito lenticular, lembrando megaflaser.

A segunda fácies é de ocorrência localizada, mas bastante importante para a caracterização paleoambiental da associação. Consiste em arenitos tabulares gradando assintóticamente em sua base, a delgados estratos lenticulares/gradacionais de arenitos e siltitos; nesse processo, cada estrato "bifurca" em estratos menores, e a superfície desses estratos (superfície de reativação) é marcada por numerosas marcas de ondas (ver ilustração no capítulo seguinte, perfil do Pai Inácio). Tal conjunto se assemelha às barras de marés (tidal bars) definidas por Mutti et al. (1988) (Fig. V.18-E). 
Figura V.18. Associação marinha (barra de marés), Morro do Pai Inácio.

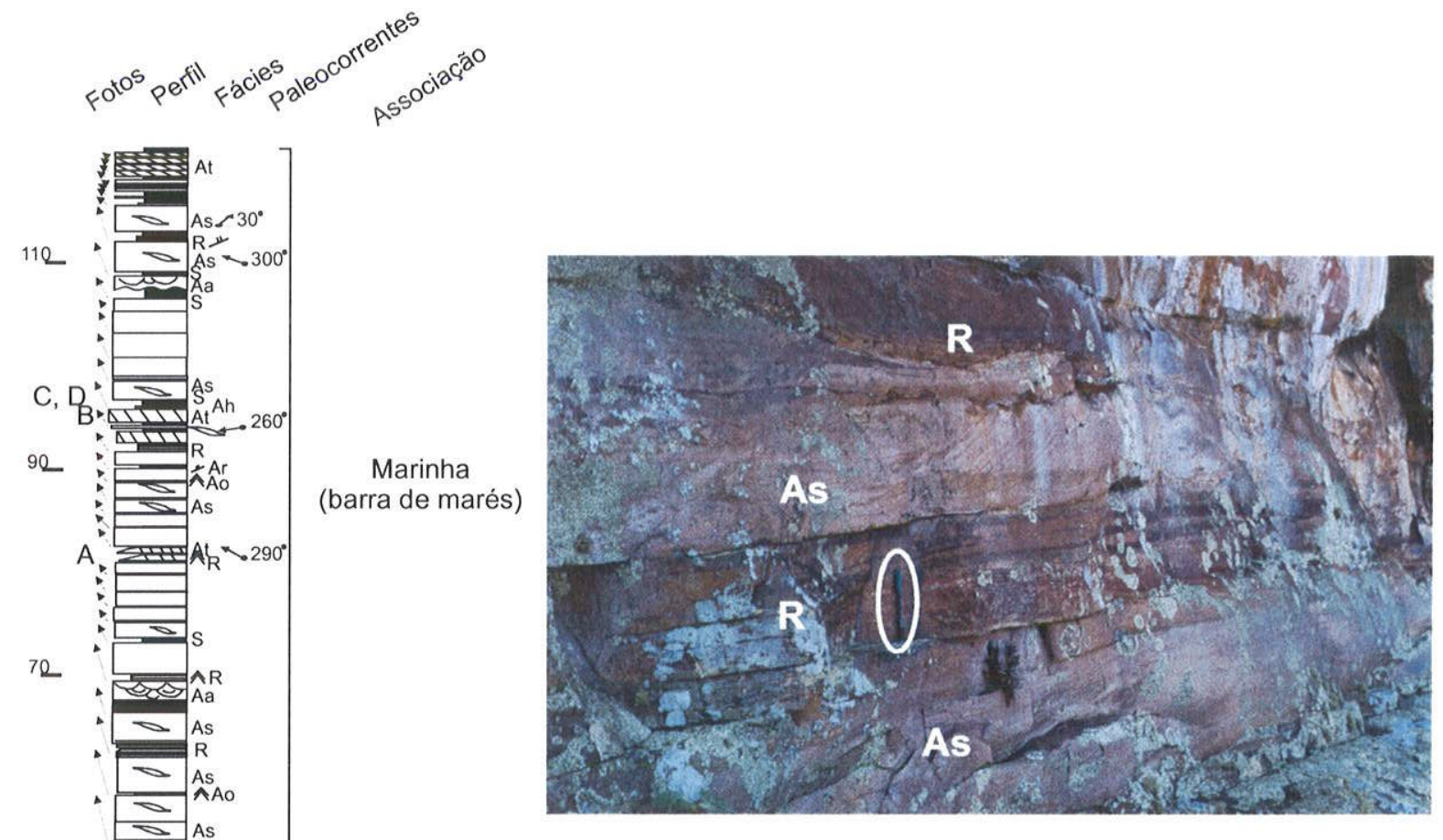

A. Dois ciclos de arenito com estratificação cruzada sigmóide As sobreposto por ritmito R. Em destaque, caneta como escala (para todas as fotos).

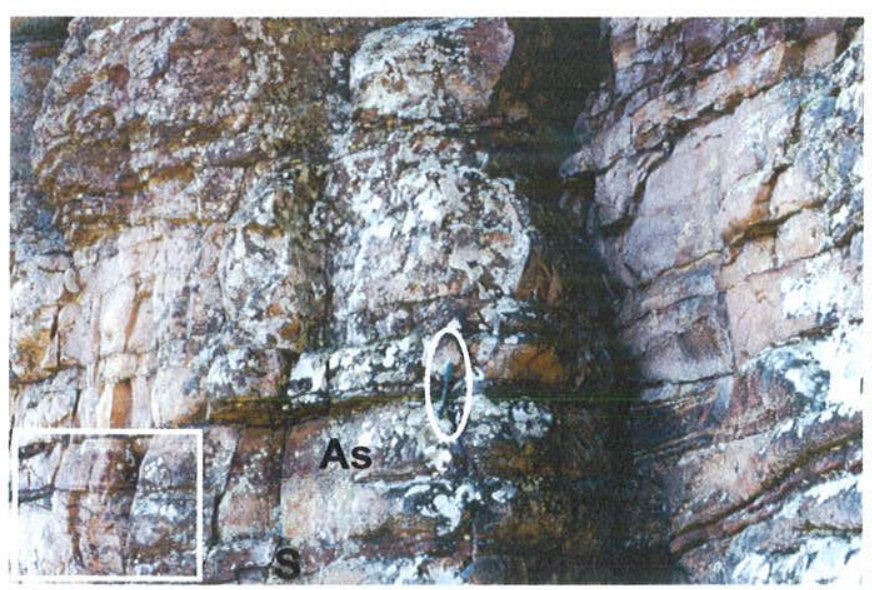

C. Arenito com estratifição sigmóide As, sobre arenito com estratos delgados e bifurcantes, sobre siltitos $\mathbf{S}$ (barras de maré). Retângulo: ver foto $\mathrm{D}$.

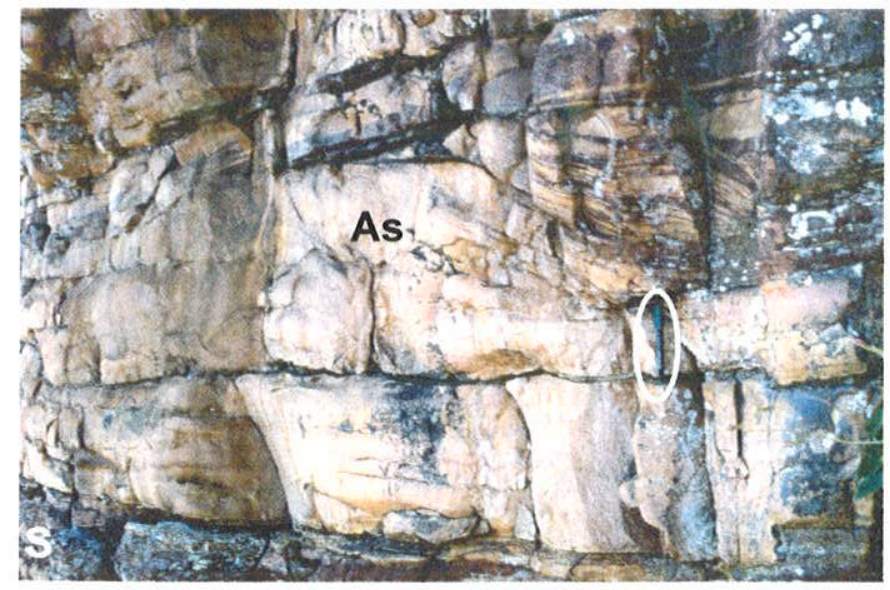

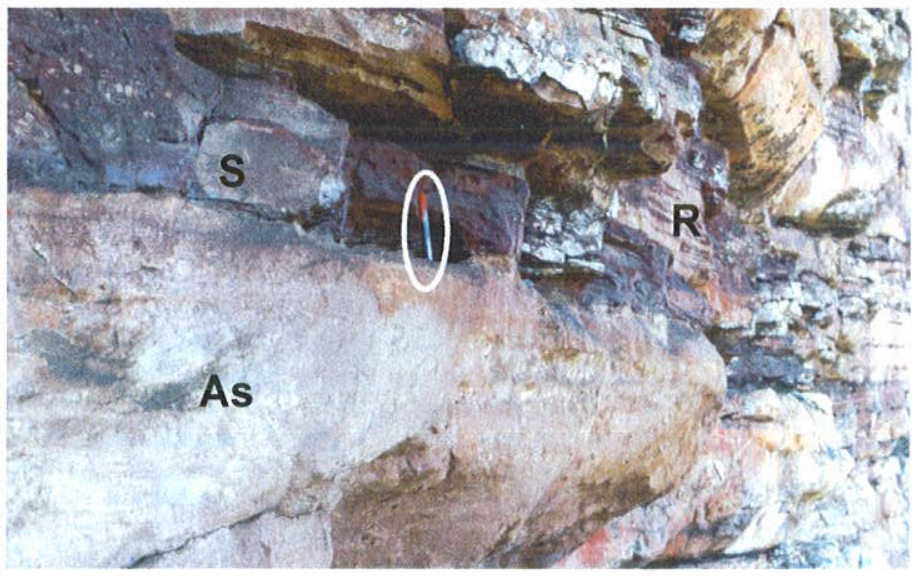

B. Arenito com estratificação sigmóide recoberto por siltito $\mathbf{S}$ e ritmito $\mathbf{R}$.

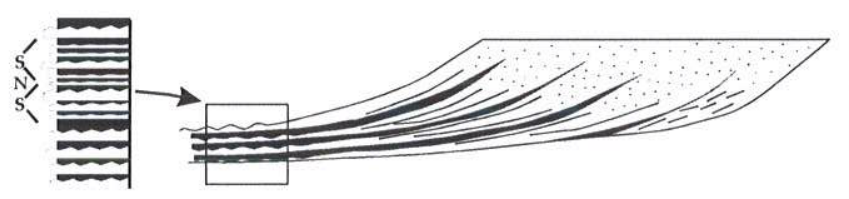

E. Geometria esquemática de uma barra de marés, mostrando migração de arenitos sigmóides, separados por lamitos. Os bottomsets mostram a existência de vários períodos distintos dentro de cada unidade; SNS refere-se possivelmente a ciclos de sizígia-quadratura-sizígia registrados na barra de maré (modificado de Mutti et al. 1988).

D. Detalhe da foto C. Arenito com estratificação sigmóide

As e drapes sílticos nos foresets e entre os estratos. Notar camada de siltio $\mathbf{S}$ subjacente. 
A terceira fácies consiste em estratos horizontais ou inclinados, de escala métrica, de arenito gradando a siltito ou ritmito (Figs, V.18-A, V.18-B). Estratificações cruzadas tabular e sigmóide são comuns no termo arenoso.

Finalmente, ritmitos delgados de arenito e siltito, e/ou siltito laminado, completam o quadro faciológico.

Tais fácies sucedem-se verticalmente segundo padrões granodecrescente ascendente, formado por arenito amalgamado e arenito gradando a siltito, e granocrescente ascendente, com siltito e ritmito sucedidos por arenito com estratos bifurcantes, neste caso representando o modelo de barra de marés (Mutti et al. 1988).

É bastante consistente o sentido das paleocorrentes para oeste, indicando um domínio das marés vazantes na construção das mencionadas barras de marés.

\section{MARINHA SHOREFACE (TEMPESTITOS)}

A associação marinha shoreface é representada por um perfil progradante composto por duas fácies: (1) arenito e siltito, recoberto por (2) arenito. Está muito bem representada no último ciclo do intervalo superior da Formação Tombador, em ambas as margens do Ribeirão Capivara (Ponto Ca1).

A fácies arenito-siltito, com quase $12 \mathrm{~m}$ de espessura, é caracterizada pelos seguintes litotipos: arenito com estratos médios e delgados, respectivamente contendo estratificação ondulada truncante hummocky (Ah) e microhummocky, bem como ritmito arenito/siltito $\mathbf{R}$, interlaminado arenito/siltito (wavy) com laminação cruzada por onda Iw, e siltito S (Fig. V.19-A, V.19-B). No topo dos estratos podem ocorrer marcas de ondas, com cristas orientadas entre as direções $250^{\circ}$ e $290^{\circ}$ (aproximadamente leste-oeste); já na parte superior do perfil, a associação apresenta superfícies com greta de contração (Fig. V.19-C). A estratificação ondulada truncante apresenta a típica geometria plano-ondulada, com significativo adelgaçamento lateral e geometria compensatória dos estratos.

A estratificação ondulada truncante (hummocky) é formada por desaceleração de correntes de densidade (geradas a partir do impacto litorâneo de grandes tempestades) seguida de deposição sob influência das ondas da superfície. Também são vistos estratos de menor porte (microhummockys), contendo ondulações de interferência no topo dos estratos, e fácies mais finas, interlaminação wavy e siltito; esse conjunto indica deposição de menor energia, relacionada a maiores profundidades (tempestitos distais).

A fácies arenosa (2) é representada por um corpo arenoso com $6 \mathrm{~m}$ de espessura, composto de estratos médios e espessos $(0,25$ a $0,5 \mathrm{~m})$, com estratificações cruzadas acanalada, tabular e de baixo angulo, laminação horizontal, e estratificação ondulada truncante 
Figura V.19. Associação marinha shoreface (margem direita do Rio Capivara).
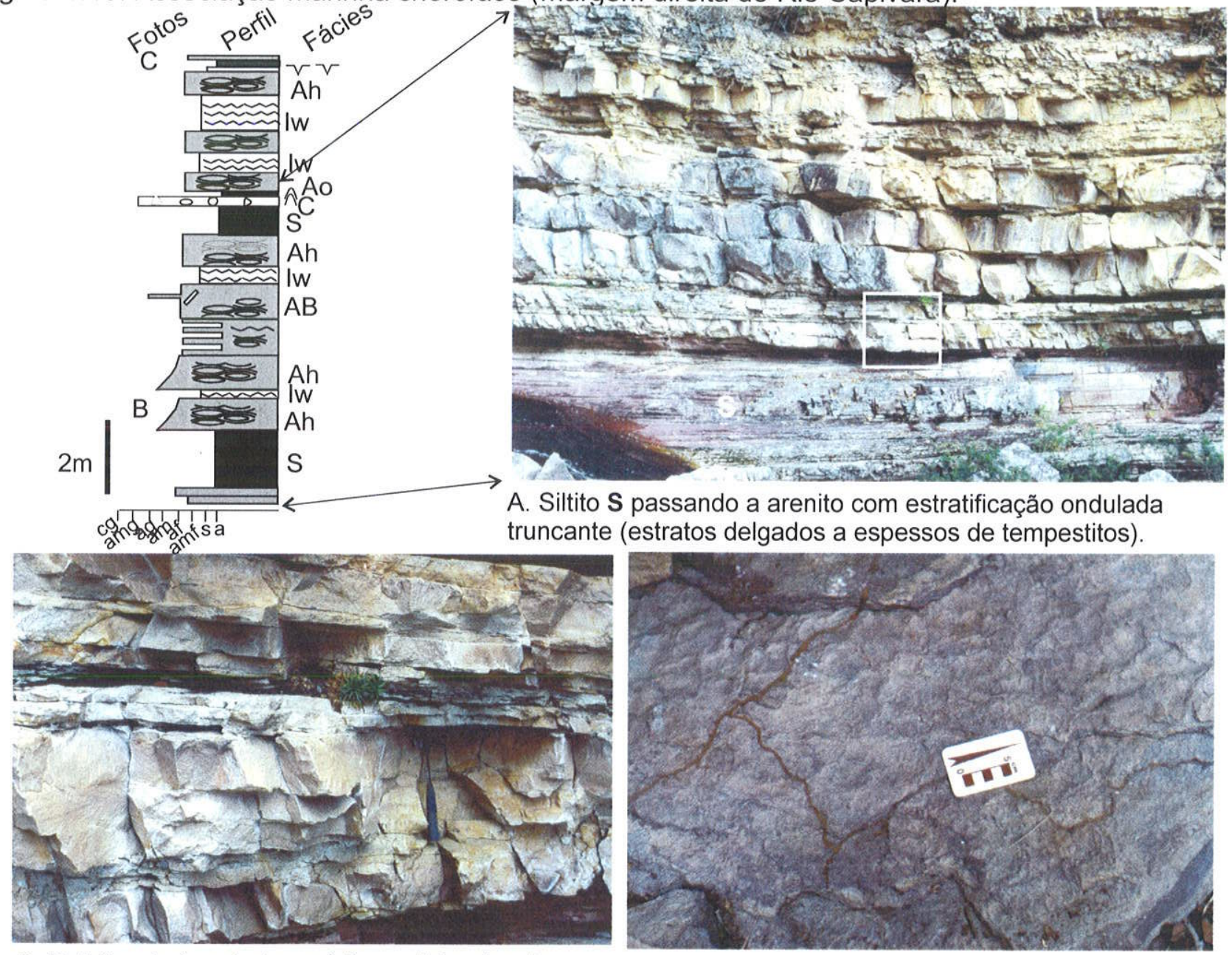

B. Detalhe de A; estratos médios e delgados de arenito com estratificação ondulada truncante.

C. Gretas de contração no topo dos tempestitos.
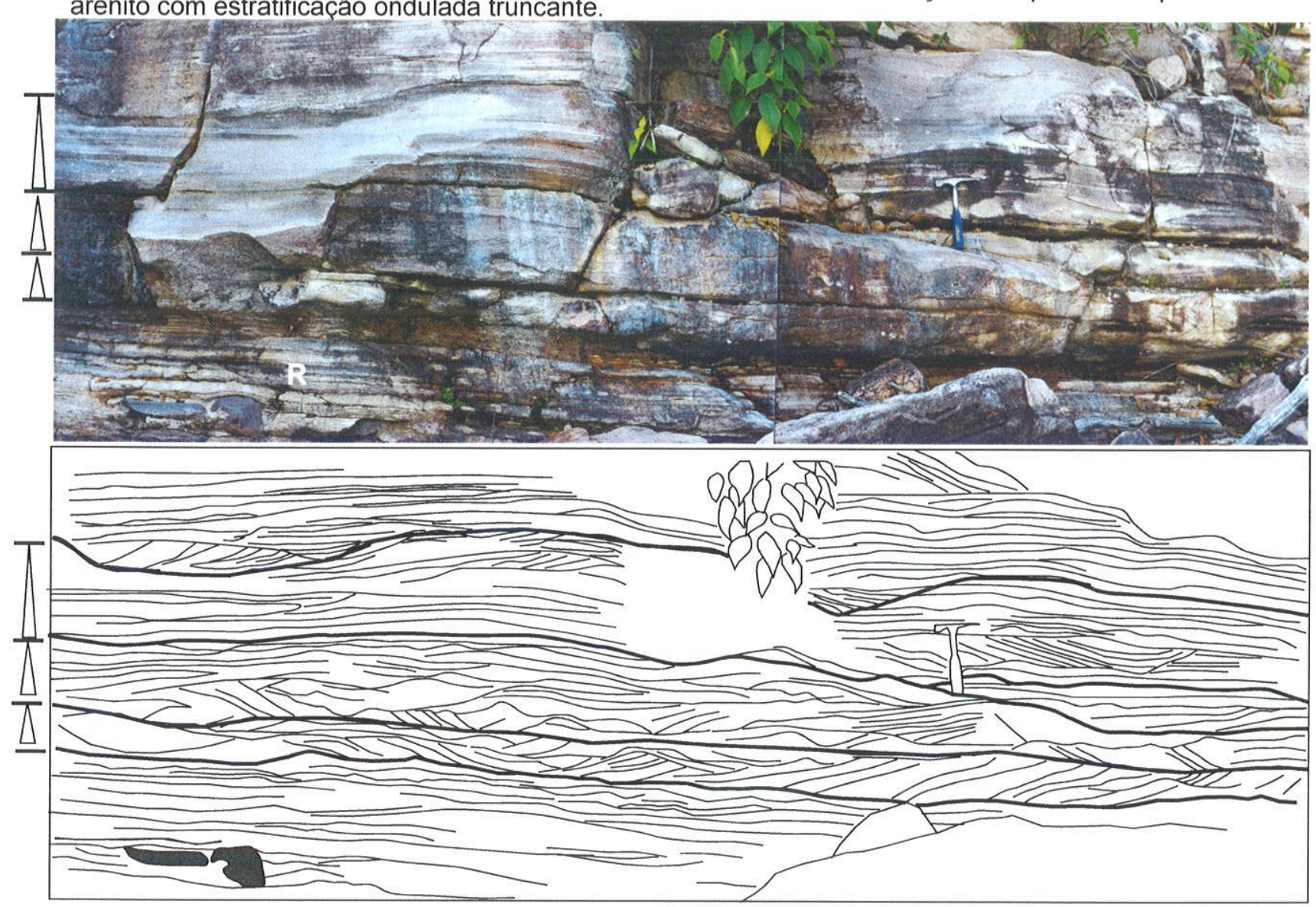

D. Ritmito arenito/siltito $\mathbf{R}$ passando acima a arenito com estratificação cruzada e ondulada truncante (hummocky). Notar grandes clastos angulosos de arenito (canto inferior esquerdo). 
(Fig. V.19-D). Localmente se observa aleitamento gradacional nos estratos e geometria compensatória. Essa associação de estratos tracionais com tempestitos sugere um ambiente marinho raso a litorâneo, possivelmente uma condição de tempestito proximal (Della 2001).

A superposição das fácies de arenito (1) sobre siltito e arenito (2) indica um perfil de arrasamento ascendente, de origem marinho raso (shoreface) a sublitorâneo.

É interessante a grande quantidade de brechas, associadas a seção de tempestitos em epigrafe, apenas no perfil do Rio Capivara (Figs. V.20-A, -B), e principalmente em sua margem esquerda (somente um ou dois niveis foram encontrados na margem direita). Esses "tempestitos brechados" oferecem dois problemas, quanto à origem dos clastos e sua relação com os processos de ondas de tempestades.

As estruturas observadas evidenciam a formação local das brechas possivelmente por choques sísmicos, e o seu pouco retrabalhamento num ambiente marinho shoreface de tempestades.

$\mathrm{Na}$ figura V.21-A são vistos dois estratos, de arenito brechado seguido por arenito róseo laminado, sobrepondo-se a um ritmito fino. Pouco à direita desse local, nota-se o arenito róseo inteiramente rompido em blocos e "soldando-se" ao arenito e brecha $\mathbf{A B}$ sotoposto, sugerindo uma origem local para a brecha (Fig. 21-B). Em outro ponto, nota-se a fácies AB afinando para arenito com laminação ondulada truncante, e passando verticalmente a interlaminado arenito e siltito (wavy) e a siltito no topo das camadas (Fig. V.21-C, -D). Os blocos apresentam imbricação, com sentido da corrente para $N 245^{\circ}$. A crista das marcas de ondas no topo dos tempestitos tem direção $\mathrm{N} 130^{\circ}$. A base das camadas de tempestito brechado é erosiva, escavando o material sotoposto. Localmente ocorrem concentrações de seixos associadas aos blocos angulosos de arenito (Fig. V.20-A).

$\mathrm{Na}$ figura V.20-B observam-se ritmitos (intercalações centimétricas de arenito muito fino e siltito) com laminação cruzada por corrente ou por ondas, sofrendo processo de fraturamento e originando um grande bloco prismático.

A fragmentação de camadas, levando à formação dos blocos praticamente in situ, poderia ser explicada através de sismos; a própria ação das tempestades poderia também induzir o fraturamento dos estratos. Deve-se destacar ainda a semelhança entre os estratos das fácies tempestito brechado $\mathbf{A B}$ e brecha e arenito BA: as figuras V.20-A e V.3-D reforçam a interpretação para o tempestito brechado.

Em alguns locais, a fácies Ah foi deformada, apresentando estratificação convoluta, na forma de anticlinais e sinclinais, e pseudonódulos (ball-and-pillow) e diques de arenito associados (Castro 2002). Internamente observa-se estratos ondulados truncantes com aleitamento gradacional (hummocky). A variação de espessura (20 a $50 \mathrm{~cm}$ ) ocorre em função da geometria ondulada do substrato preexistente; nos baixos a espessura dos sedimentos é 
Figura V.20. Associação marinha shoreface (Fácies arenito e brecha).

$$
\begin{aligned}
& \text { Perfil da margem esquerda } \\
& \text { do Rio Capivara }
\end{aligned}
$$

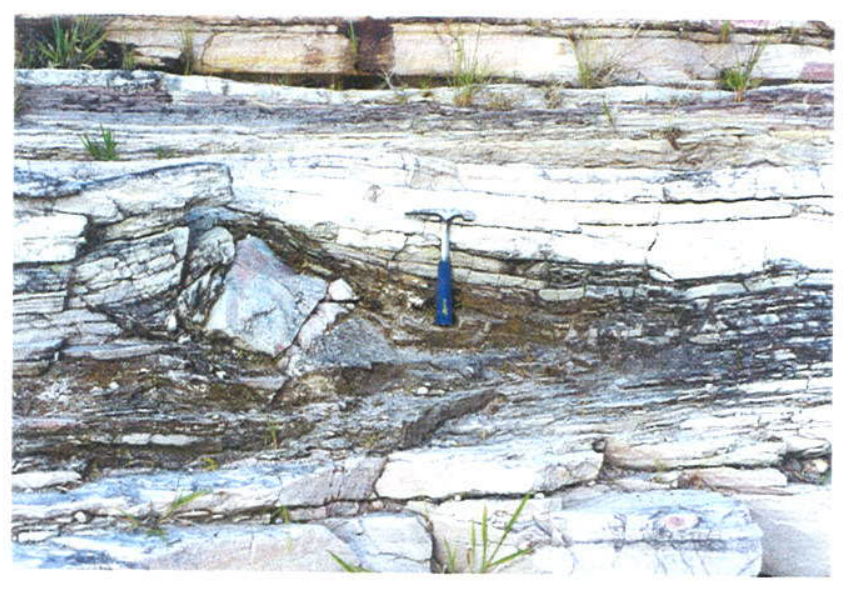

B. Ritmito arenito/siltito e clasto anguloso incluso.
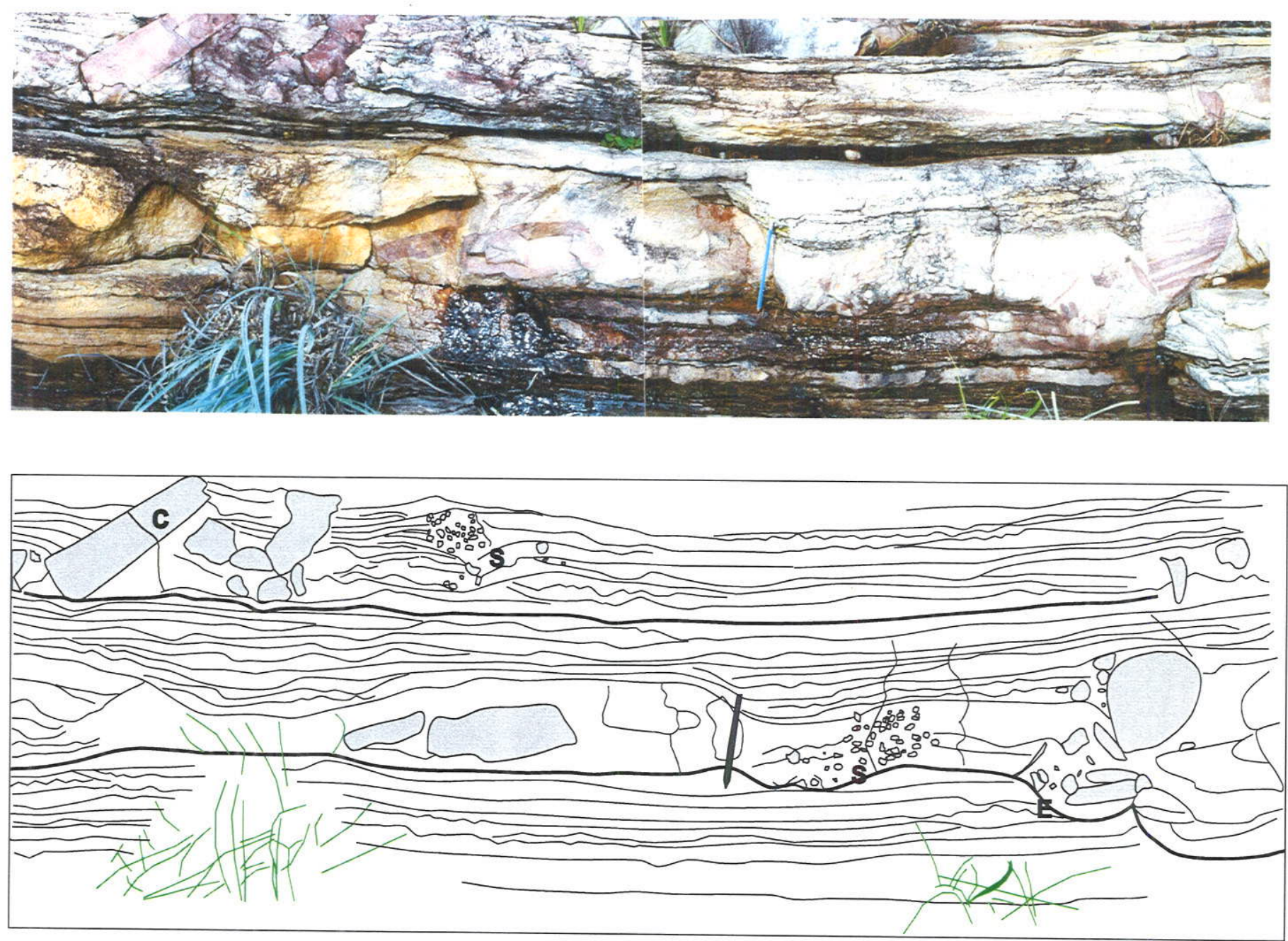

A. Estratos formados por brecha (clastos em tom de cinza no desenho) gradando a arenito com laminação ondulada. Notar concentração local de seixos $\mathbf{S}$, escavação $\mathrm{E}$ e clasto imbricado $\mathrm{C}$. 
Figura V.21. Associação marinha shoreface (Fácies arenito e brecha).

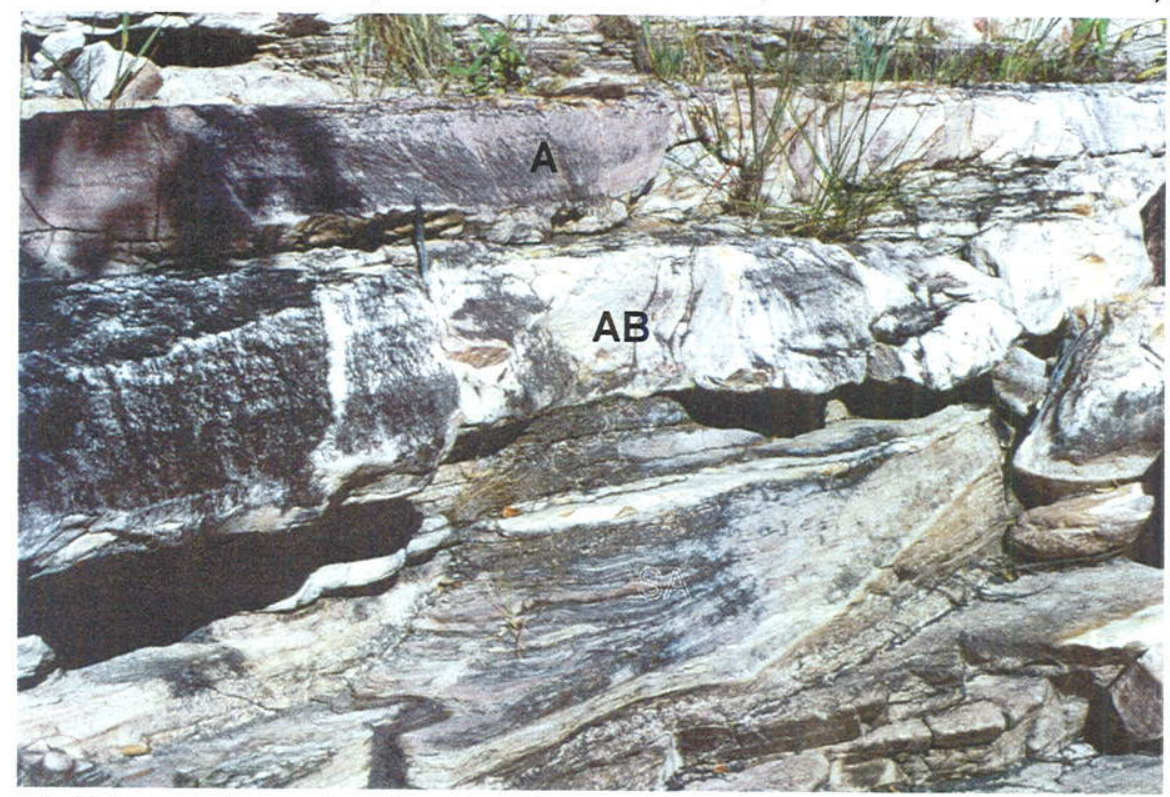

A. Estratos de arenito e brecha $A B$ e de arenito róseo $\mathbf{A}$, sobrepostos a espesso siltito-arenito SA.

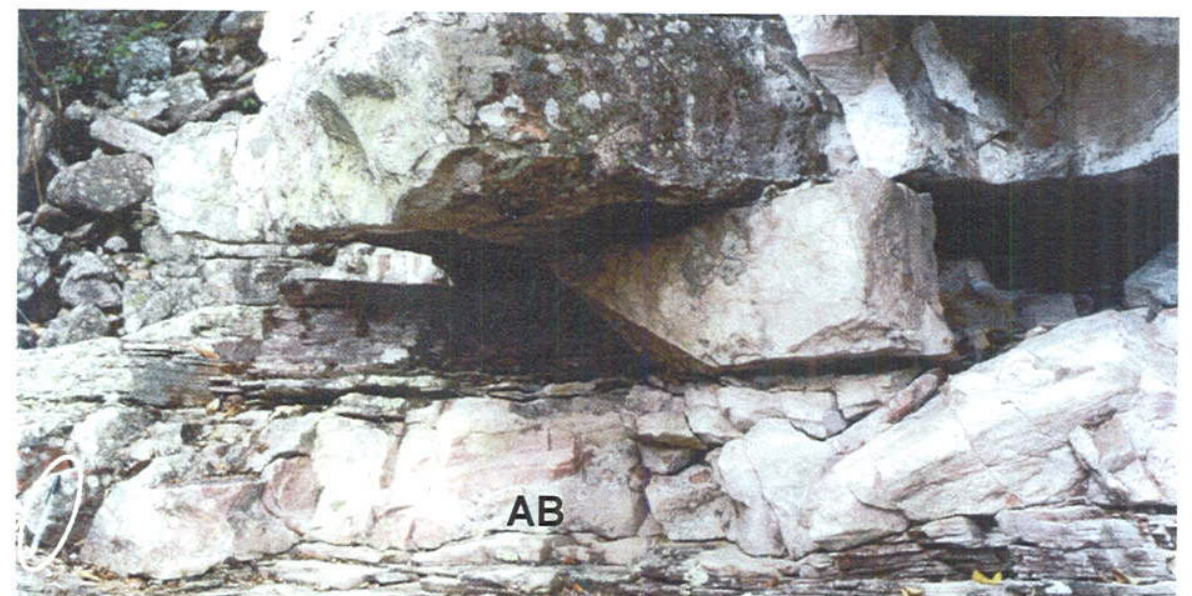

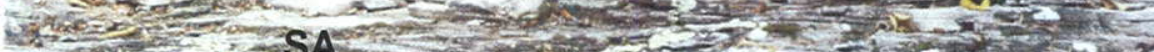

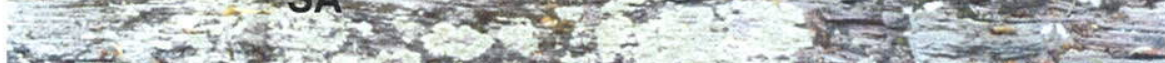

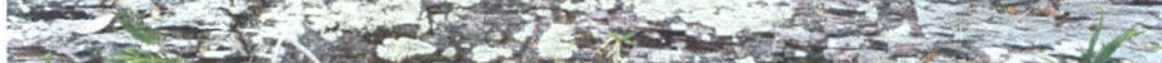

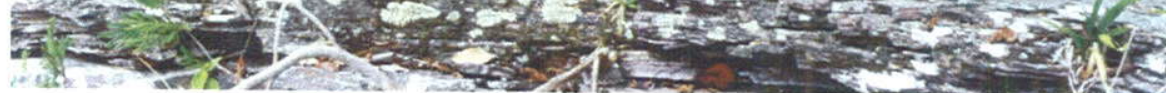

C. Tempestitos com clastos angulosos AB sobrepostos a siltitos-arenitos SA. A escala é uma caneta no círculo à esquerda

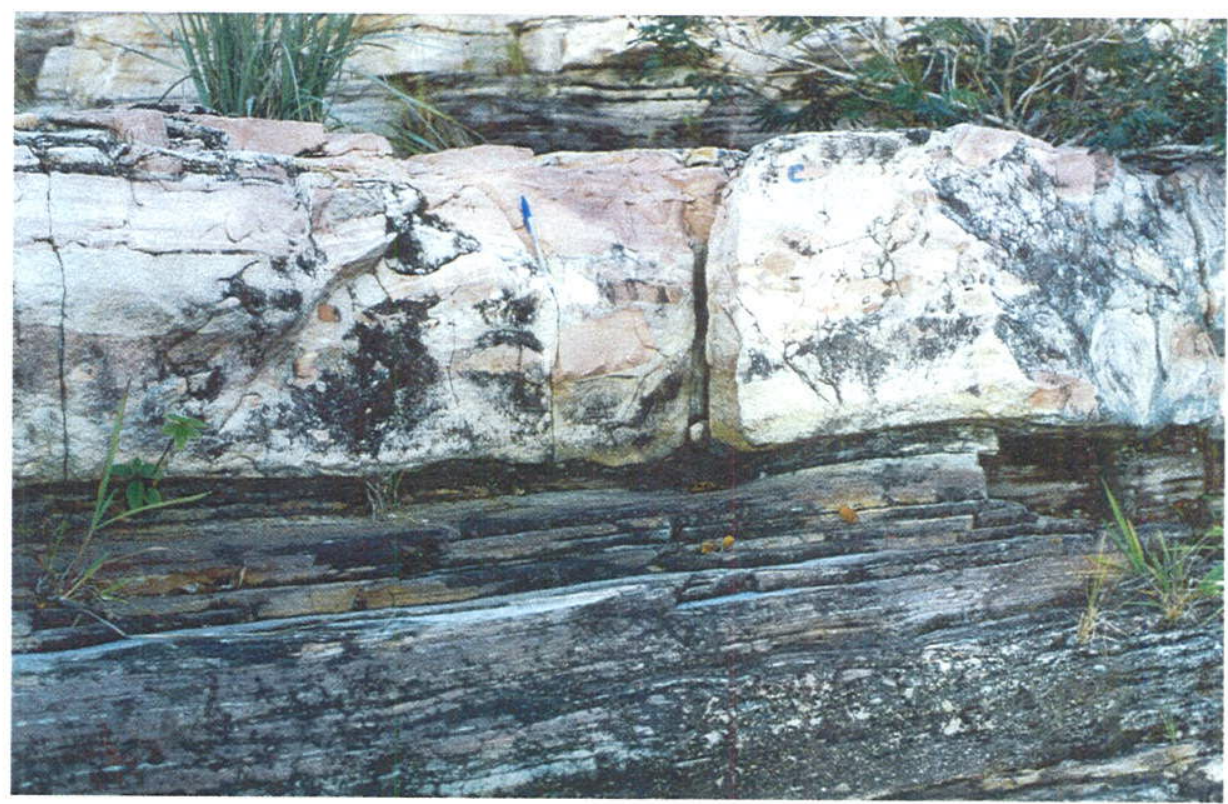

$B$. Foto tirada à direita da foto $A$, notando-se o estrato de arenito róseo (foto $A$ ) rompido em blocos e mergindo com 0 arenito e brecha AB.

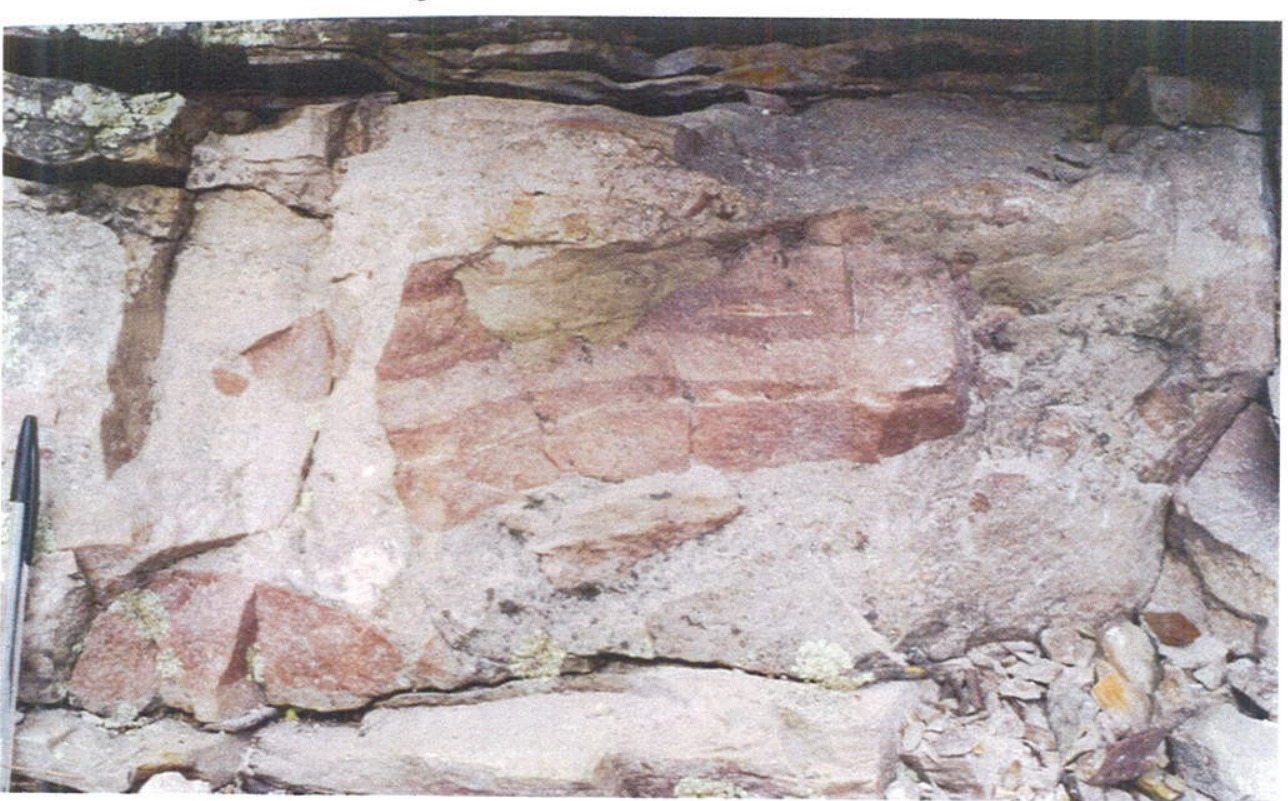

D. Detalhe da foto C. Observar clasto anguloso de arenito e laminaçoes onduladas truncantes no topo. 
maior, enquanto que nos altos há adelgaçamento-compensação das camadas, comum em tempestitos.

Tal afloramento, situado próximo à foz do Rio Lapão, apresenta duas camadas deformadas (Fig. V.22-A). A camada inferior (1) apresenta $80 \mathrm{~cm}$ de espessura e contém diques de injeção de areia, pseudonódulos (ball-and-pillow) e dobras convolutas. Os diques possuem até $30 \mathrm{~cm}$ de altura, aparentemente não apresentam estrutura interna, e deformam a laminação ao redor. As estruturas mais comuns são dobras convolutas em forma de semi-círculo. As dobras convolutas formam pares de anticlinais, formados em resposta à carga arenosa nos sinclinais e que corresponde a lobos de subsidência. Os anticlinais e sinclinais são assimétricos e apresentam até $80 \mathrm{~cm}$ de largura e $20 \mathrm{~cm}$ de altura, sendo truncados no topo pela erosão oriunda de correntes de tempestade (Fig. V.22-B).

Os pseudonódulos (ball-and pillow) caracterizam-se por corpos de arenito na forma de bolas concêntricas, com $10 \mathrm{~cm}$ de diâmetro, apresentando litologia semelhante a do sedimento em que se encontram. Parte da estrutura primária (estratificação ondulada truncante hummocky) encontra-se preservada na base desta camada (Fig. V.22-B).

A camada arenosa superior (2), com espessura de $15 \mathrm{~cm}$ (Fig. V.22-A), apresenta pequenas dobras perturbando a estrutura primária; a base daquela camada é erosiva $e$ ondulada.

Próximo ao afloramento descrito, no mesmo nivel e na mesma fácies, foram observadas dobras convolutas formando dois sinclinais separados por um anticlinal com pequena calha sinformal no meio (Fig. V.22-B). Os sinclinais e o anticlinal são assimétricos e apresentam até $1 \mathrm{~m}$ de largura por $70 \mathrm{~cm}$ de altura. A distância entre os anticlinais varia consideravelmente, observando-se ainda fraturamento dentro das camadas convolucionadas. Notam-se ainda pseudonódulos (ball-and-pillow) com diâmetro em torno de $10 \mathrm{~cm}$; que algumas vezes possuem forma caótica ou até forma de pêra. A estrutura é comumente encontrada "flutuando" dentro de depósitos mais finos com estratificação convoluta irregular.

As seguintes evidências corroboram com a hipótese das estruturas de deformação terem sido formadas a partir de abalos sísmicos:

1. Por se tratar de um evento instantâneo e de grande extensão, as estruturas geradas são restritas a um único horizonte estratigráfico e que pode ser correlacionado por amplas áreas;

II. As estruturas são truncadas pela camada sobreposta, não deformada, indicando que a desestabilização ocorreu anteriormente à deposição desta camada e, sendo assim, a idéia de sobrecarga estaria descartada;

III. Liqüefação ou fluidização são processos comuns disparados a partir de choques sísmicos; 
Figura V.22. Associação marinha shoreface (Rio do Lapão).
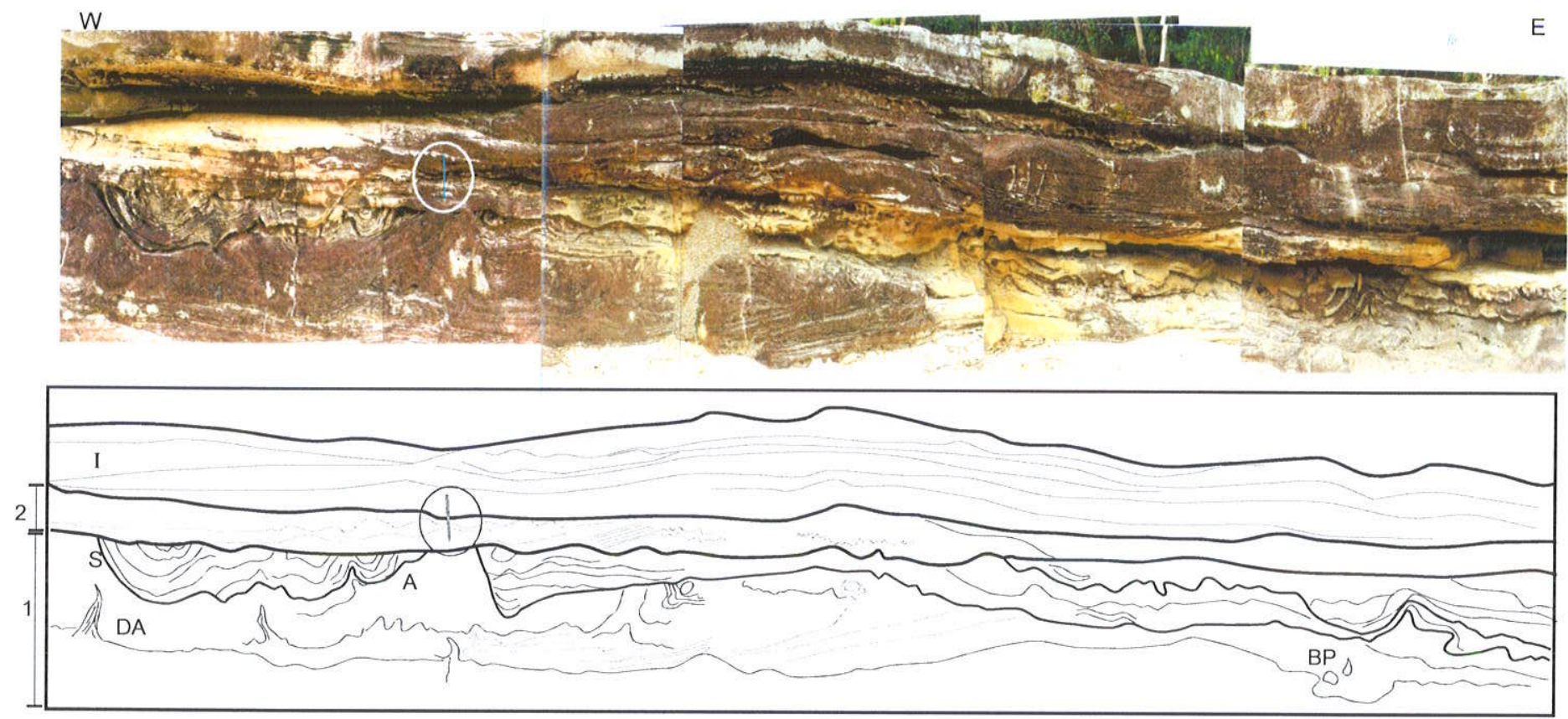

A. Arenito com estratificação ondulada truncante (hummocky) e convoluta. $\mathrm{DA}=$ dique de areia, $\mathrm{BP}=$ ball-and-pillow, $\mathrm{S}=$ sinclinal, $\mathrm{A}=$ anticlinal, 1 e 2 são camadas, $\mathrm{I}$ = camada não deformada.

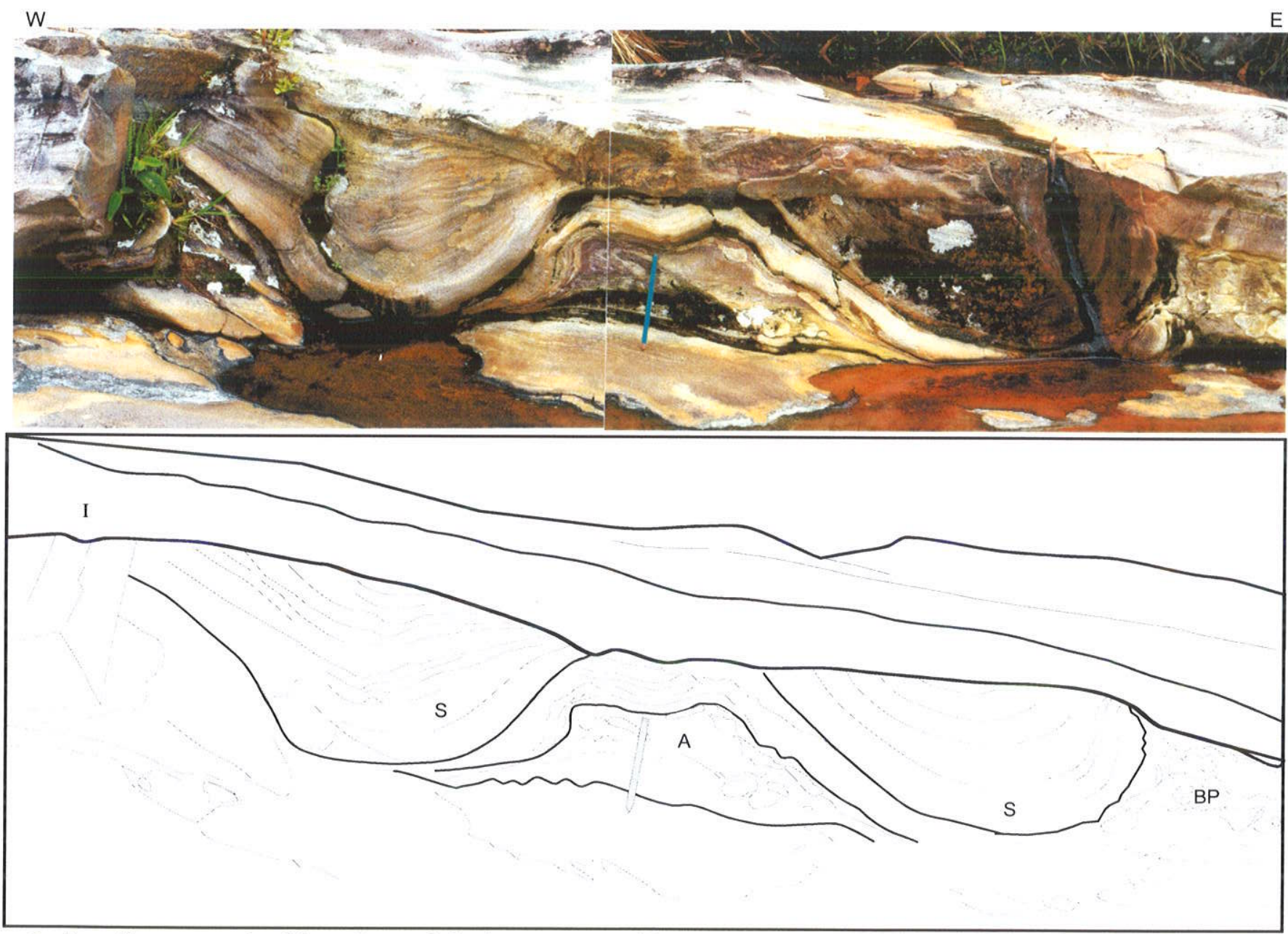

B. Arenito com estratificação ondulada truncante (hummocky) e convoluta. BP = ball-and-pillow, $\mathrm{S}=$ sinclinal $\mathrm{A}=$ anticlinal, $\mathrm{I}$ = camada não deformada . 
IV. Não houve influência de taludes (declives), favoráveis ao disparo de fluxo de detritos e correntes de turbidez, ou seja, as estruturas de deformação não foram formadas a partir de escorregamento ou deslizamento;

V. Feições semelhantes são descritas na literatura como tendo sido acionadas a partir de sismos (Rossetti 1999). 


\section{CAPÍTULOVI \\ SEQÜÊNCIAS DEPOSICIONAIS NA FORMAÇÃO TOMBADOR}

\section{VI.1. INTRODUÇÃO}

A Formação Tombador, com espessura de quase $600 \mathrm{~m}$ na região, pode ser dividida em dois intervalos. O intervalo inferior apresenta os sistemas fluvial, eólico, litorâneo, deltaico e estuarino. No intervalo superior são encontrados sistemas de leque aluvial (incluindo brechas), fluvial, eólico, litorâneo, deltaico e marinho plataformal com ação de ondas de tempestades, formados numa época de tectonismo marcado por sucessivos episódios de soerguimento e canibalização da própria bacia.

Foram levantados dois perfis praticamente completos da Formação Tombador, nos vales dos rios Mucugezinho e Ribeirão (intervalos inferior e superior), onde é possível observar a evolução da unidade sob a ótica da Estratigrafia de Seqüências, e que serão apresentados neste capítulo. O perfil do Morro do Pai Inácio, correspondente à parte do intervalo inferior da Formação Tombador será descrito aqui também. O último ciclo do intervalo superior da Formação Tombador, o qual corresponde ao último evento de soerguimento levando à formação de leques até a passagem gradacional para a Formação Caboclo, será apresentado no capítulo seguinte, onde serão mostrados e correlacionados quatro perfis estratigráficos.

Com exceção do perfil do Morro do Pai Inácio (intervalo inferior da Formação Tombador), todos os demais perfis foram levantados no flanco leste do Anticlinal do Sincorá (vales do Mucugezinho, Lençóis, Ribeirão e Capivara).

Uma dificuldade na aplicação da Estratigrafia de Seqüências neste trabalho foi devido à falta de conhecimento quanto ao tempo de deposição dos sedimentos da Formação Tombador. $O$ reconhecimento das seqüências de $3^{a}$ e $4^{a}$ ordens foi feito baseado nas espessuras, mudanças abruptas de fácies e sistemas deposicionais, e através de comparação com seqüências do Fanerozóico. É possivel, porém, que as seqüêencias de $3^{\text {a }}$ e $4^{a}$ ordens identificadas na Formação Tombador não possuam a mesma equivalência em tempo das seqüências de $3^{\mathrm{a}}$ e $4^{\mathrm{a}}$ ordens pertencentes ao Fanerozóico, devido às grandes diferenças ambientais do Pré-cambriano.

A identificação de parasseqüências e conjuntos de parasseqüências nem sempre foi possivel, principalmente nos tratos de sistemas de mar baixo (em se tratando de uma bacia sem talude e leque submarino), e também em direção ao continente. A aplicação da Estratigrafia de Seqüências em sistemas fluviais e eólicos também não é tarefa fácil, devido à 
ausência de finos de planície de inundação, de vegetação, do reconhecimento de interfluvios, ausência de fósseis, etc. Por outro lado, esses sistemas e seus respectivos limites de seqüência são constatados a partir da presença de conglomerados e brechas do intervalo superior. É importante ressaltar que os tratos de sistemas de mar baixo, transgressivo e mar alto reconhecidos nos sistemas continentais estão relacionados às descidas e subidas do nivel do lençol freático. As variações no freático são influenciadas pelas do nivel do mar, pois os sistemas eólico e fluvial descritos a seguir se desenvolveram próximo à costa.

\section{VI.2. INTERVALO INFERIOR}

Os perfis dos rios Mucugezinho e Ribeirão foram divididos em dois intervalos, inferior e superior, devido à presença de conglomerados e brechas no intervalo superior. O perfil do Morro do Pai Inácio, o qual corresponde ao intervalo inferior da Formação Tombador foi descrito a parte; este morro representa um dos mais completos registros sedimentares, em termos de empilhamento estratigráfico referentes a sistemas costeiros e marinhos dominados por ondas e marés. Em seguida são descritos os perfis dos vales dos rios Mucugezinho e Ribeirão, para finalmente concluir-se com a correlação entre os três perfis.

\section{PERFIL DO MORRO DO PAI INÁCIO}

O Morro do Pai Inácio apresenta uma das melhores exposições do intervalo inferior da Formação Tombador (Grupo Chapada Diamantina). Situa-se no km 231, ao norte da rodovia BR-242, já fora dos limites do parque. O topo do morro está a $1.150 \mathrm{~m}$ acima do nível do mar e apresenta um relevo de $250 \mathrm{~m}$. Como o Morro do Pai Inácio está localizado próximo ao eixo do anticlinal do Sincorá, suas camadas estão praticamente na horizontal (Fig.VI.1).

Foram levantados três perfis no Morro do Pai Inácio, nas faces leste, norte e sul, totalizando $170 \mathrm{~m}$.

No Morro do Pai Inácio visualizam-se seis quebras fisiográficas, ou superfícies de descontinuidade muito expressivas (Figs.VI.1 e VI.2), correlacionáveis com quebras vistas no Morro do Camelo (Fig.VI.3), Morrão, Morro do Brejão, Morro da Bacia, etc. Através de um perfil levantado no Morro do Pai Inácio observou-se que essas descontinuidade correspondem a discordâncias ou limites de seqüências, conforme será visto mais adiante. Nos outros dois perfis descritos a seguir năo foi possível observar todas essas quebras já que aqui o intervalo inferior está contínuo, sendo mais fácil observar e descrever todo o empilhamento.

Foram identificados quatro sistemas principais: fluvial-marinho, marinho (barra de marés), estuarino-marinho e fluvial/eólico. 
Figura VI.1. Visão frontal-face leste do Morro do Pai Inácio. Observar as seis superfícies de descontinuidade, bem expressivas, correspondentes a limites de seqüências.

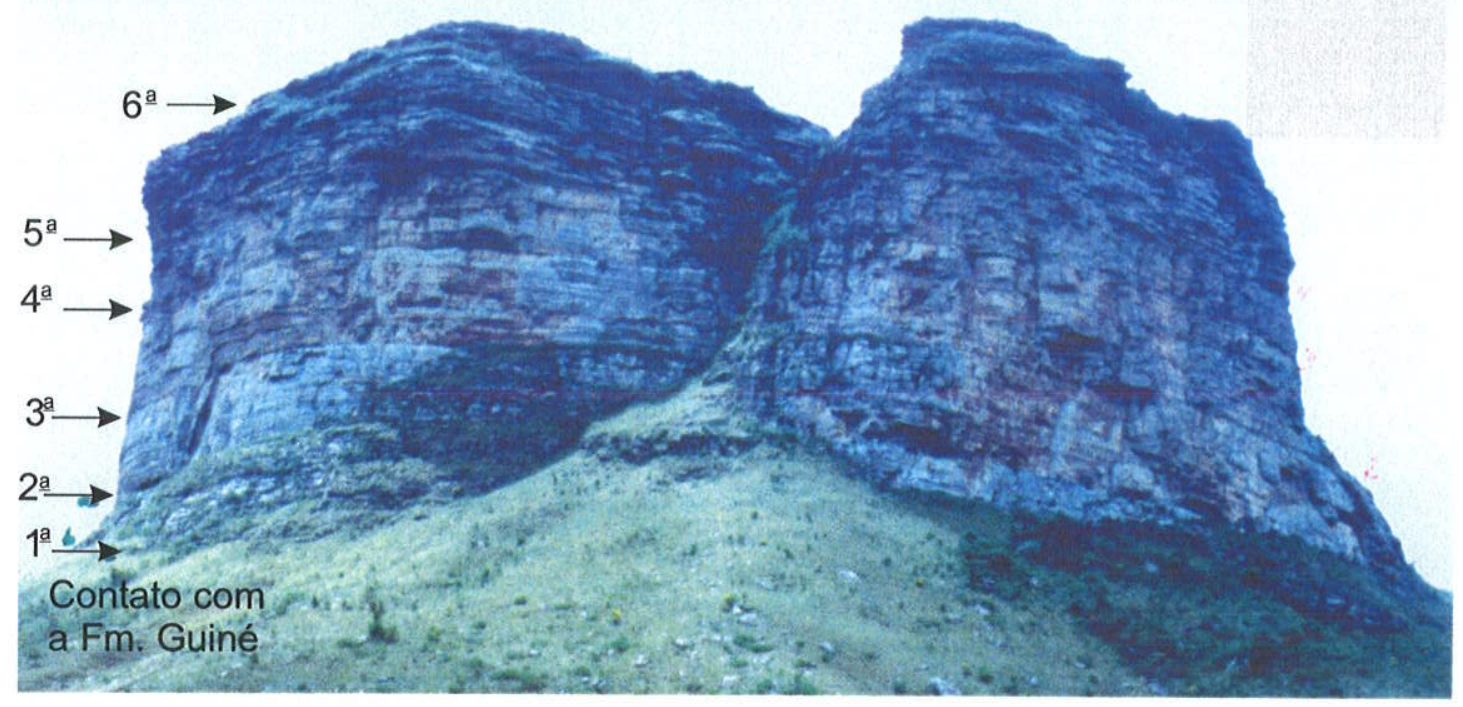

Figura VI.2. Visão lateral (face sul) do Morro do Pai Inácio, mostrando as superfícies de descontinuidade.

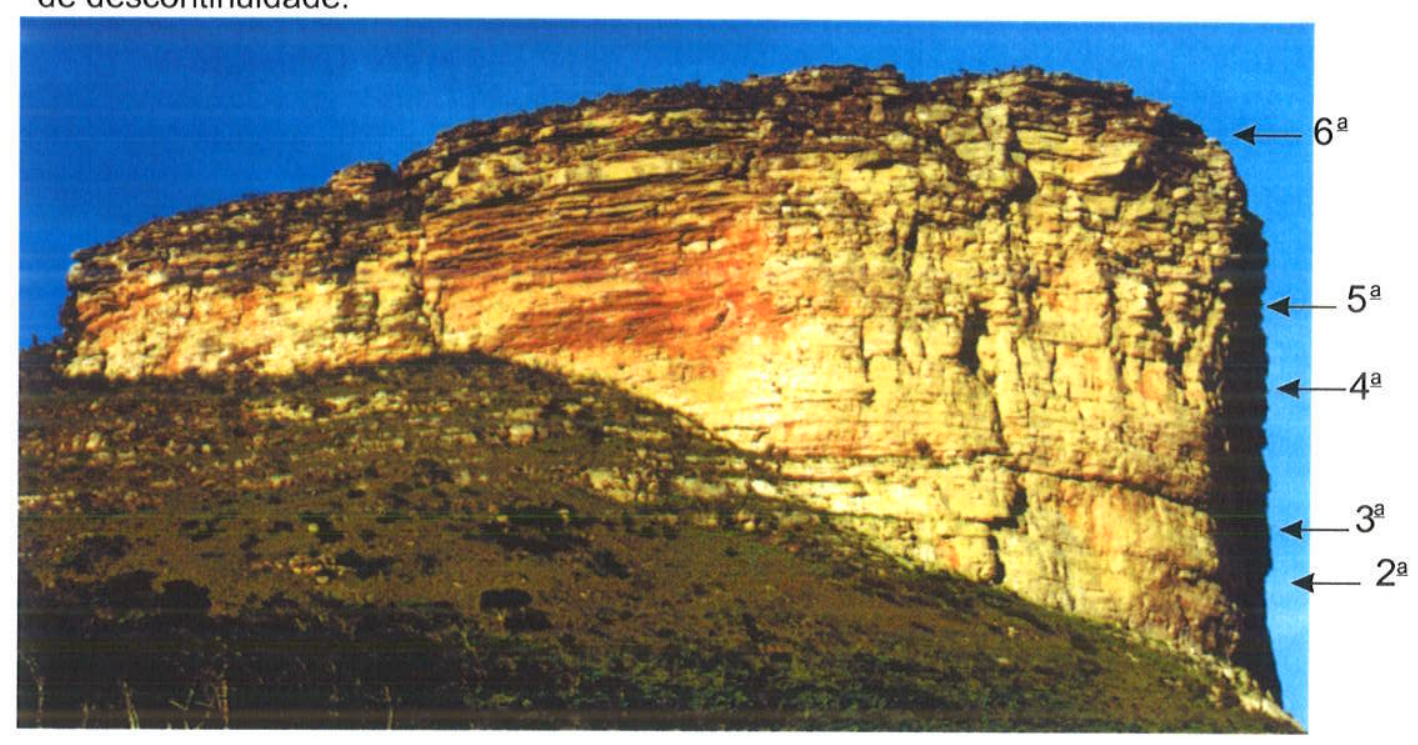

Figura VI.3. .Morro do Camelo. Notar as superfícies de descontinuidade, ou quebras, facilmente traçadas na foto e semelhantes às do Morro do Pai Inácio.

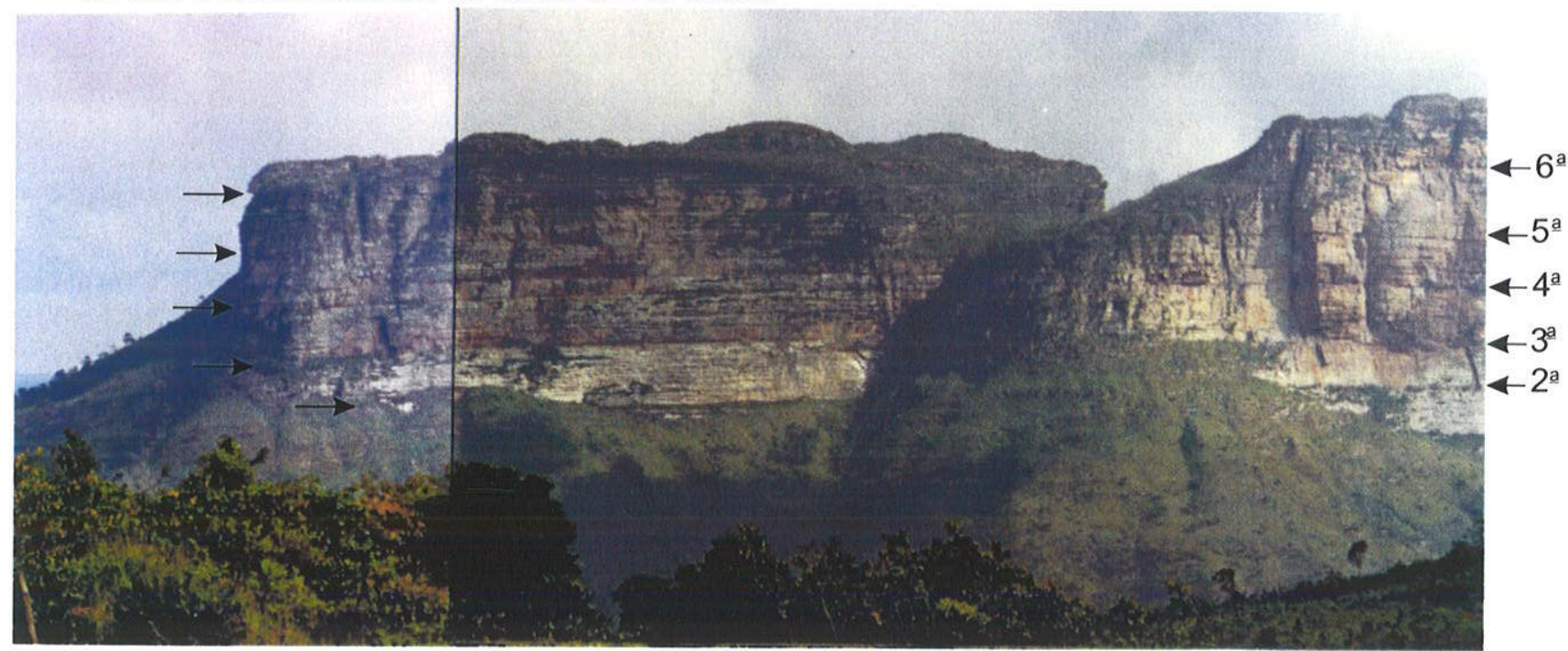


O intervalo inferior da Formação Tombador no Morro do Pai Inácio pode ser dividido em cinco sistemas maiores de acordo com o quadro a seguir:

\begin{tabular}{|c|c|c|c|}
\hline Arenito grosso/médio & Fluvial/eólico & $6^{Q} \quad$ Limite de & $\begin{array}{l}\text { Trato de sistema de mar } \\
\text { baixo (TSMB) }-6^{\mathrm{a}} \\
\text { seqüência }\end{array}$ \\
\hline $\begin{array}{l}\text { Arenito; arenito e siltito } \\
\text { Arenito e raro siltito }\end{array}$ & $\begin{array}{l}\text { Fluvial a estuarino-marinho } \\
\text { Fluvial-marinho }\end{array}$ & $5^{\circ} \quad$ Limite de & $\begin{array}{l}\text { Trato de sistema de mar } \\
\text { baixo (TSMB) e trato de } \\
\text { sistemas transgressivo } \\
\text { (TST) }-5^{\text {a }} \text { seqüencia }\end{array}$ \\
\hline Arenito e siltito/ritmito & Marinho (barra de marés) & seqüência (LS) & $\begin{array}{l}2^{a}, 3^{a}, 4^{a} \text { sequiências de } \\
\text { alta freqüência da } 1^{a} \\
\text { seqüência }\end{array}$ \\
\hline Arenito e raro siltito & Fluvial-marinho & & TSMB da $1^{a}$ seqüência \\
\hline \multicolumn{2}{|c|}{ Formação Guiné } & seqüência (LS) & \\
\hline
\end{tabular}

$\mathrm{Na}$ base do perfil observam-se arenitos finos a muito finos com laminações horizontal e cruzada clino-ascendente de frente deltaica, pertencentes à Formação Guiné, sobrepostos abruptamente por arenitos médios a grossos com estratificação cruzada e siltitos (fluvial/marinho) pertencentes à Formação Tombador (Fig. VI.4). O limite entre as duas unidades é caracterizado por uma discordância, formada em resposta a um rebaixamento do nível do mar. Sobreposto a esse pacote ocorre uma superfície transgressiva sobre a qual notam-se arenitos e siltitos/ritmitos intercalados de barras de maré (associação estuarina), formado em resposta à subida do nível do mar, e inseridos em tratos de sistemas transgressivo e mar alto (Fig. V.18).

O limite inferior da segunda seqüência (Fig. VI.4-A) ocorre na base de arenitos médios/grossos sigmoidais sobrepostos a siltitos e arenitos finos com influência de ondas e inseridos num trato de sistemas transgressivo. Um espesso pacote de siltitos representa possivel inundação máxima. Sucede uma progradação de arenitos com intercalações de siltitos marinhos dentro do trato de sistemas de mar alto. Paleocorrentes dirigem-se mais para oeste (variam de $220^{\circ}$ a $300^{\circ}$ ).

A terceira e quarta seqüências são semelhantes à segunda com arenitos sigmoidais intercalados com siltitos (Fig. VI.4-B), e subordinadamente arenitos com estratificação cruzada tabular seguidos de ritmitos (Fig. VI.4-C). Superfícies de reativação podem interromper os arenitos sigmoidais e serem seguidas por numerosos drapes de argila associados a tidal bundles (Fig. VI.4-D). Feições canalizadas maiores também estão presentes (Fig. VI.4-E). 
Figura VI.4 . Perfil do Morro do Pai Inácio.

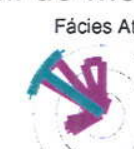

N. De dados $=13$
Desvio pardáo $=9.3 \%$
Vetor médio $=30.5$

Fácies Aa As

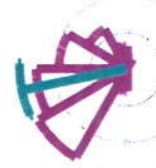

N. De dados $=32$

Vetor médio $=258$

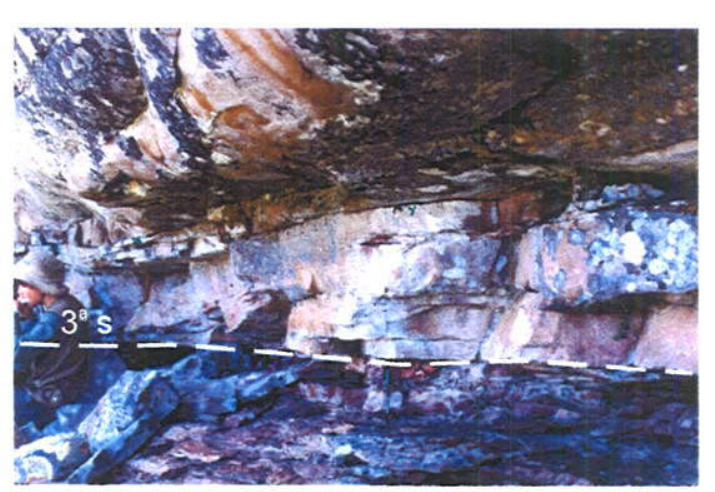

B. Terceira superfície $\left(3^{\mathrm{a}} \mathrm{s}\right)$ posicionada no contato do arenito com estratificação cruzada e siltito.

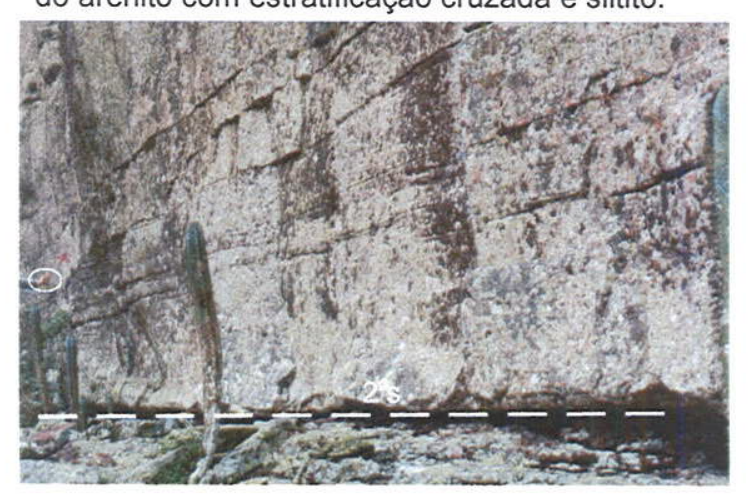

A. Segunda superfície $\left(2^{\mathrm{a}} \mathrm{s}\right)$ posicionada no contato do arenito com estratificação cruzada e siltito. A escala é uma mão em destaque.
$170 \mathrm{~m}$ Face norte do morro

152

${ }^{2} 300^{\circ}$

$A_{A a}^{A a}$

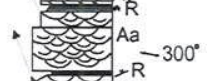

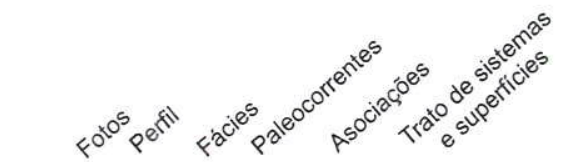

Face sul
do morro

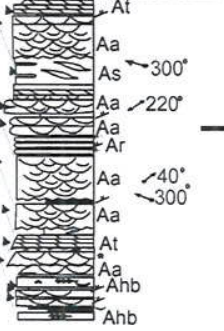

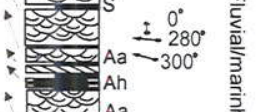

TSMB

—LS $5^{\mathrm{a}}$ superficie

(3 ordem)

TSMA

D $\triangle 30^{\circ}$

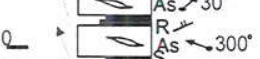

$E,{ }_{S}^{A s}$

$100: \square$

$\mathrm{D}$

se

${ }_{A a r}^{R}$

${ }_{30} \mathrm{C}$ Nas D

$\square$

72 एक्षि

$B \rightarrow \square$ As

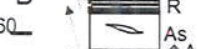

$-\underset{\wedge A 0}{A s}$

50

.

.$D_{A s}^{A s}$

$40,270^{\circ}$

$\stackrel{\mathrm{AS}}{2} 270^{\circ}$

A $\underset{\mathrm{AAO}}{260}$

$32 \rightarrow a^{A s} 265^{\circ}$

$$
\text { - } 260^{\circ}
$$

중 $A$

$180^{\circ} \circ 0^{\circ}$

$\sim 260^{\circ}$

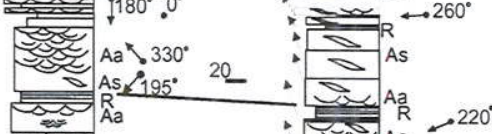

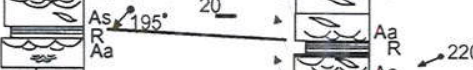

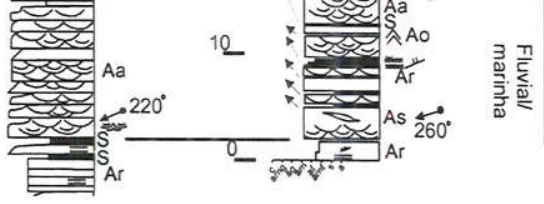

- ST $^{\mathrm{ST}}$

TST

- LS $4^{\circ}$ superficie

(4 ordem)

TSMA

- ST

TST

_LS $3^{\text {a }}$ superfície

(4ºrdem)

D. Arenito com estratifição cruzada sigmóide As

TSMA

- ST

TST

-LS 2 'superficie ( $4^{3}$ ordem)

TST/TSMA

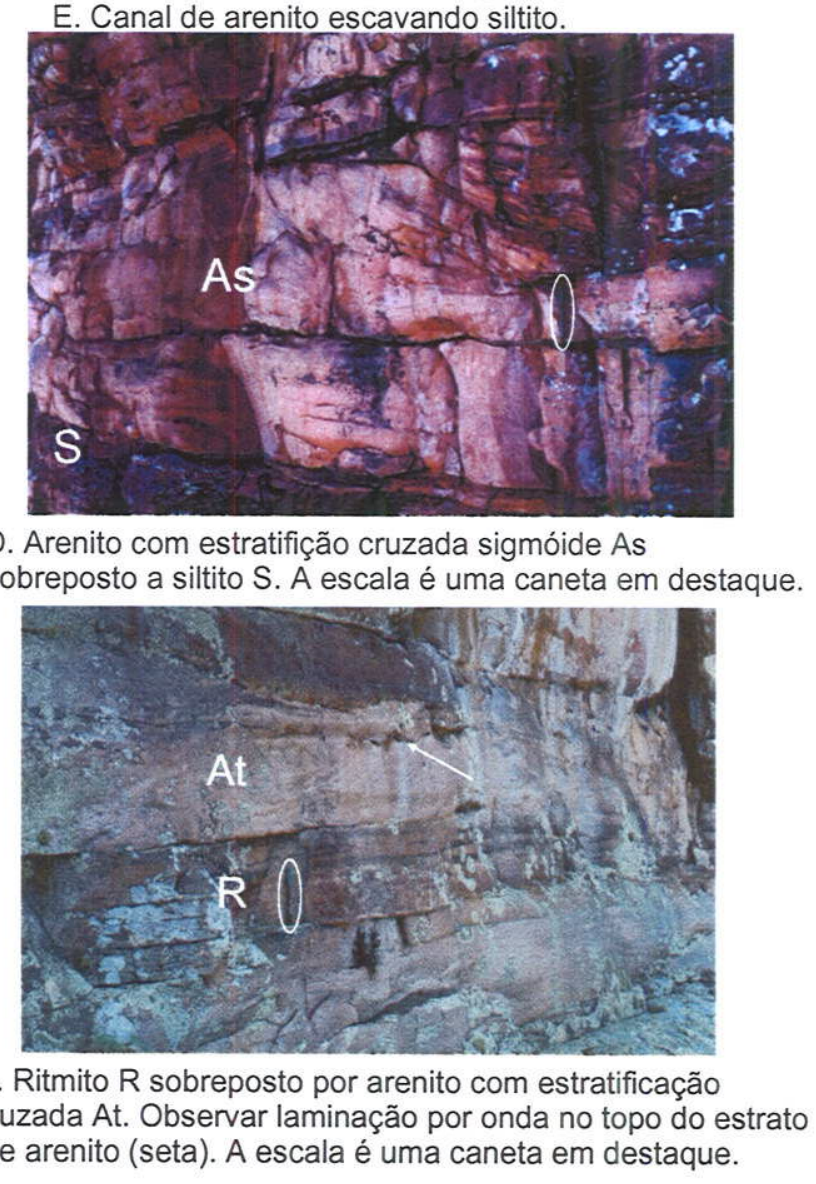

-ST

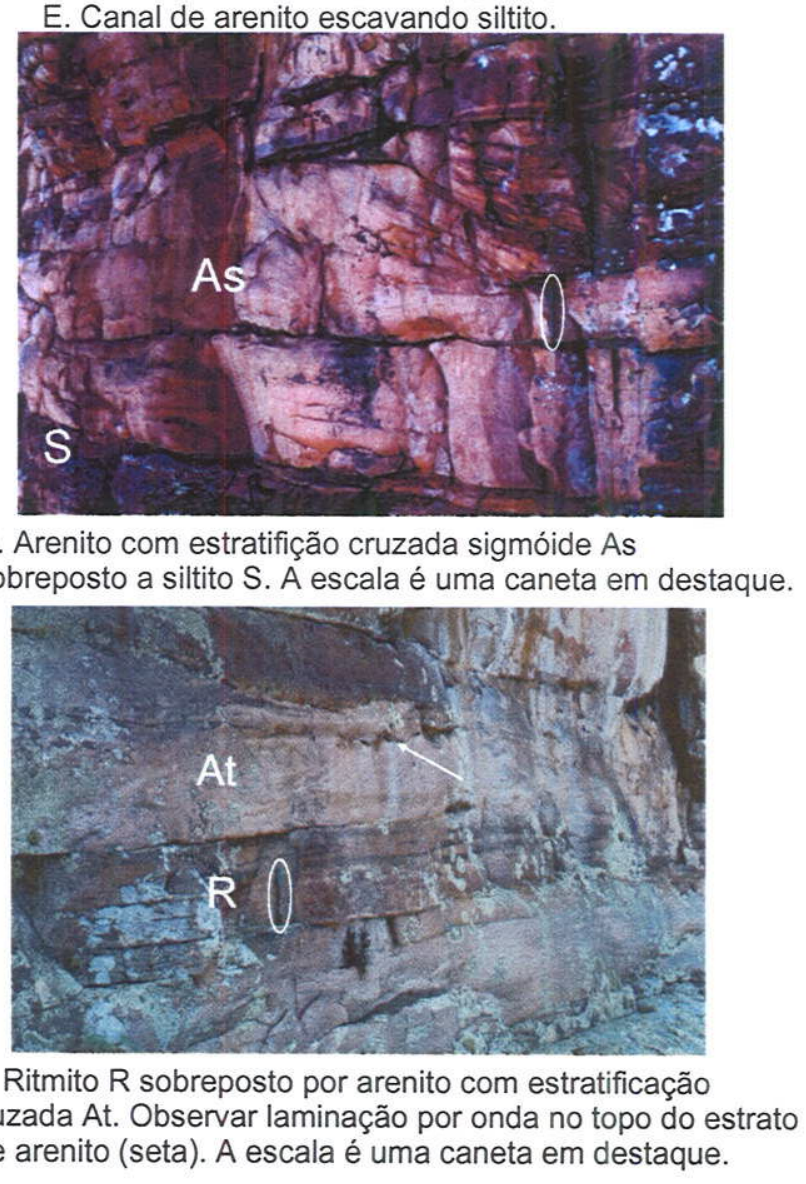

TSMB

C. Ritmito R sobreposto por arenito com estratificação cruzada At. Observar laminação por onda no topo do estrato

-LS 1superficie de arenito (seta). A escala é uma caneta em destaque. (discordância) 
A quinta seqüência inicia-se com depósitos essencialmente fluviais contendo algumas intercalações marinhas (trato de sistemas de mar baixo), e sobrepostos por depósitos fluviais e estuarinos intercalados (trato de sistemas transgressivo). Nesse intervalo é notável a abrangência de sedimentos finos para o topo do morro, provavelmente ligados a uma grande transgressão marinha, provavelmente de ordem menor (Fig. V.17).

Por fim, um novo limite de seqüências, na base da sexta superfície, marca a passagem de depósitos estuarinos/marinhos (arenitos com estratificação cruzada acanalada e sigmóide intercalados com ritmitos retrabalhados por ondas), para depósitos fluviais e eólicos (arenitos grossos com estratificação cruzada acanalada e arenitos finos com estratificação tabular tangencial na base de médio porte). A sexta superfície ou seqüência é formada devido a um rebaixamento do nivel do mar, provavelmente de $3^{\text {a }}$ ordem, diferente dos quatro últimos limites, e caracterizando o final da sedimentação costeira com grande influência de marés e ondas e passagem para um ambiente mais continental. As paleocorrentes dos arenitos eólicos indicam sentido para noroeste, enquanto que os arenitos fluviais apresentam paleocorrentes para sudoeste.

Através do estudo da análise faciológica vertical feita no Morro do Pai Inácio foram identificadas e interpretadas duas seqüências como sendo seqüências de $3^{\text {il }}$ ordem. O limite da primeira ocorre no contato entre as formações Guiné e Tombador (ou $1^{\text {a }}$ superfície), marcando a passagem de sistemas deltaico-marinho para fluvial-marinho. O limite da segunda seqüencia de $3^{\text {a }}$ ordem ou $6^{\text {a }}$ superfície, marca a passagem de sistemas estuarino-marinho para fluvial/eólico. Na seqüência inferior de $3^{\text {a }}$ ordem foram reconhecidas 4 seqüências de $4^{a}$ ordem, ou de alta freqüência.

Resumidamente, a primeira e a quinta seqüências são semelhantes sendo constituídas por intercalação de elementos fluviais-marinhos (siltitos transgressivos) e estuarinos-marinhos. $\mathrm{Na}$ segunda, terceira e quarta seqüências ocorrem arenitos intercalados com siltitos, de barra de marés. Todo o intervalo é recoberto por depósitos fluviais e eólicos, característicos de um trato de sistemas de nivel de base baixo de uma nova seqüência ( $3^{a}$ ordem).

\section{PERFIL DO RIO MUCUGEZINHO}

O trajeto do rio Mucugezinho acompanha boa parte da BR-242 que está em sua margem direita. Ele Nasce próximo do Morrão e recebe águas de muitas serras altas da região. Apresenta várias tocas, escorregadeiras e alguns poços, sendo o mais conhecido o Poço do Diabo com $14 \mathrm{~m}$ de altura. 
No perfil do intervalo inferior levantado no Rio Mucugezinho não foi possível ver a base da Formação Tombador. O perfil, com mais de $250 \mathrm{~m}$, de espessura foi levantado em afloramentos junto a drenagem do rio e na rodovia BR-242.

Foram reconhecidos nove intervalos envolvendo cinco associações faciólogicas; estuarina proximal, estuarina distal-marinha, praia, eólica e fluvial. Cinco seqüências foram identificadas nesse perfil, cujo o quadro é apresentado a seguir:

\begin{tabular}{|c|c|c|c|}
\hline Arenito & Fluvial & & TSMB \\
\hline $\begin{array}{l}\text { Arenito } \\
\text { Arenito }\end{array}$ & $\begin{array}{l}\text { Praia (Bar Mucugezinho) } \\
\text { Eólico } \\
\text { Fluvial (Toca da Marina) }\end{array}$ & LS & TST \\
\hline $\begin{array}{l}\text { Arenito e siltito } \\
\text { Arenito }\end{array}$ & $\begin{array}{l}\text { Estuarino distal-marinho (Mengão) } \\
\text { Fluvial }\end{array}$ & LS & $\begin{array}{l}\text { TST } \\
\text { TSMB }\end{array}$ \\
\hline $\begin{array}{l}\text { Arenito e siltito } \\
\text { Arenito }\end{array}$ & $\begin{array}{l}\text { Estuarino-marinho (Bar do Pelé) } \\
\text { Fluvial/eólico }\end{array}$ & LS & TST \\
\hline $\begin{array}{l}\text { Arenito } \\
\text { Arenito e siltito }\end{array}$ & Estuarino-marinho (Ponte) & LS & TST \\
\hline
\end{tabular}

O perfil inicia-se no afloramento da ponte, com arenitos com estratificações cruzadas acanaladas e sigmóides preenchendo canais que recortam ritmitos e siltitos, da associação estuarina-marinha (Figs. V.15 e VI.5-A). São freqüentes estruturas indicativas de marés, como por exemplo flaser, linsen e wavy, e retrabalhamento por onda no topo dos estratos Este pacote representa um trato de sistemas transgressivo (TST).

A seguir um rebaixamento do nível do mar erode a plataforma gerando uma discordância e conseqüente deposição de arenitos fluviais e eólicos, do trato de sistemas de mar baixo (TSMB. Nova subida do nível do mar culmina com a deposição de arenitos com estratificações cruzada acanalada e sigmóide (paleocorrentes para sudoeste) intercalados com arenitos finos com laminação por onda e siltitos, da associação estuarina-marinha, posicionados no trato de sistemas transgressivo, da segunda seqüência (em frente ao Bar do Pelé, fig. VI.5-B),

A terceira seqüência inicia-se com arenitos fluviais, com ocasional intercalação marinha, trato de sistemas de mar baixo (TSMB) sobreposto por arenitos com estratificação cruzada acanalada e sigmóide intercalados com ritmitos e siltitos da associação estuarina/marinha (TST) ("Mengão", fig. V.16 e VI.5-C). 
Figura VI.5. Perfil do intervalo inferior do Rio Mucugezinho/BR-242.
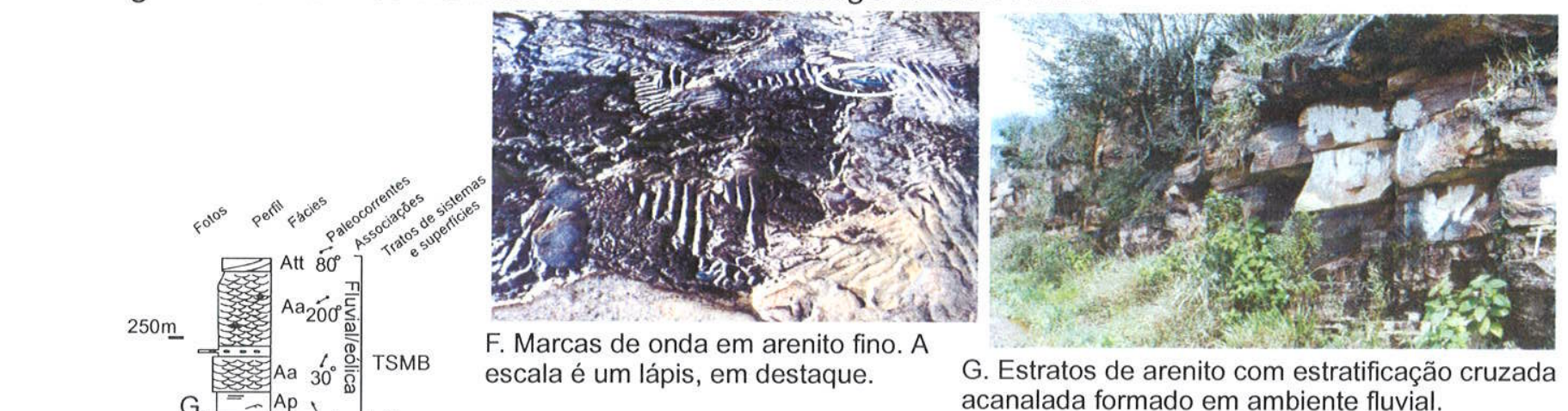

G. Estratos de arenito com estratificação cruzada acanalada formado em ambiente fluvial.
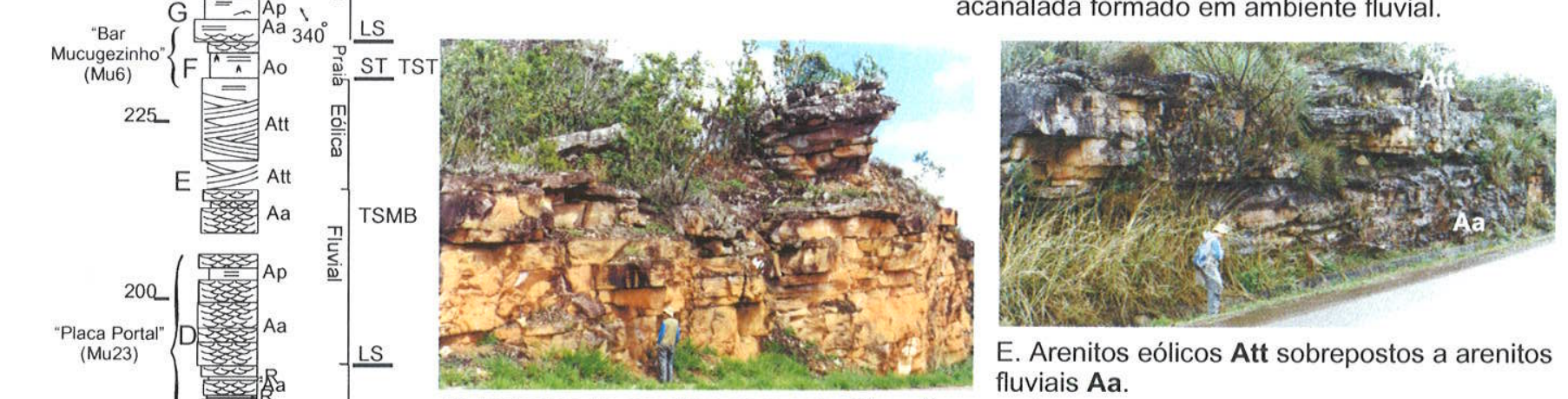

E. Arenitos eólicos Att sobrepostos a arenitos fluviais Aa.

D. Estratos de arenitos com estratificação cruzada

TST acanalada separados por delgados níveis de siltito.

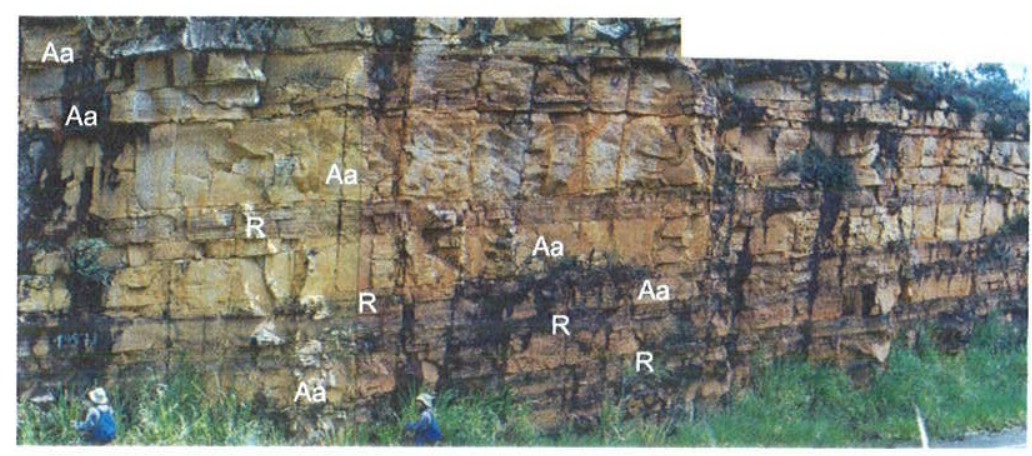

C. Intercalação de arenito com estratificação cruzada acanalada e ritmito.

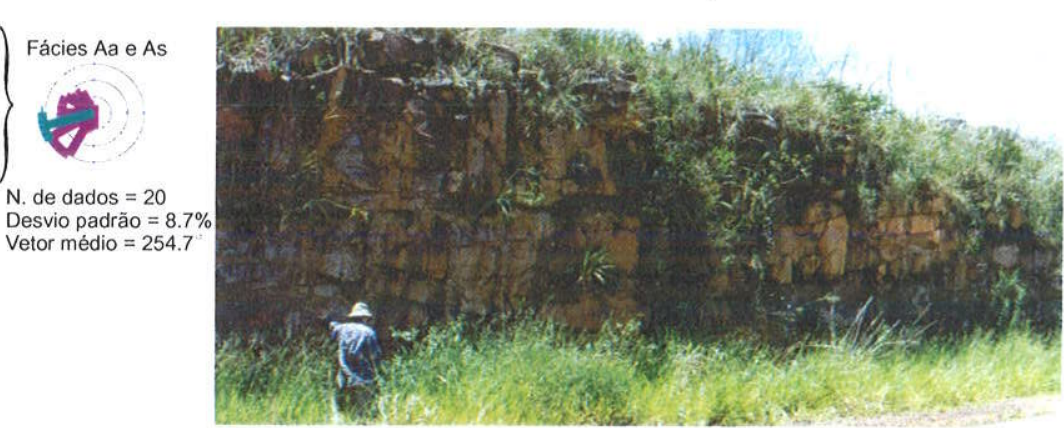

TSMB

B. Canal preenchido por arenito com estratificação cruzada sigmóide.

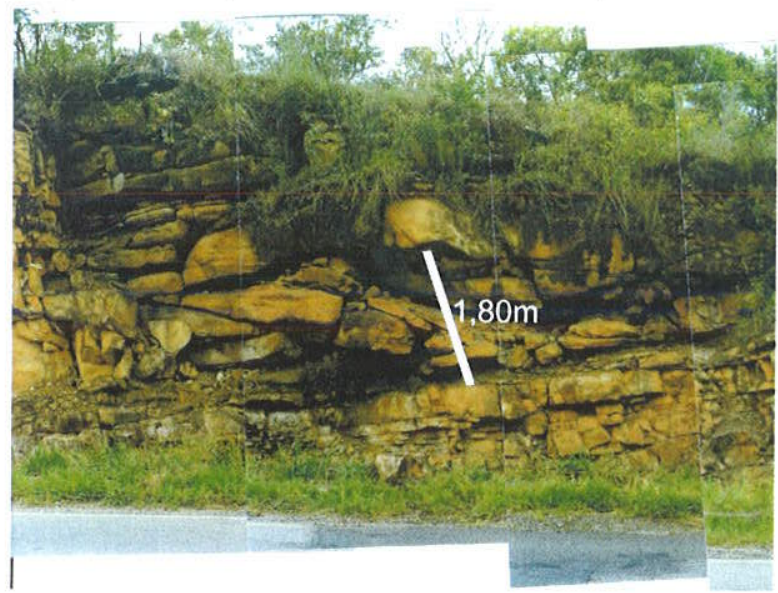

A. Arenito médio com estratificação cruzada sigmóide. 
Acima no perfil, é identificada uma discordância formada em resposta à queda do nível do mar resultando na deposição de arenitos flúvio-estuarinos e fluviais (Fig. VI.5-D) sobrepostos por arenitos eólicos (Fig. VI.5-E), de trato de sistemas de mar baixo. O mar avança e arenitos finos com laminação por ondas, de praia (Fig. VI.5-F), são depositados (TST).

Finalmente, a última seqüência é caracterizada por arenitos fluviais (Fig. VI.5-G), formados possivelmente num trato de sistemas de mar baixo.

Resumidamente, observa-se na parte inferior do perfil analisado intercalação de sistemas fluviais/costeiros e deltaicos/marinhos sucedidos verticalmente a sistemas fluviais e eólicos. De um modo geral, o intervalo inferior do perfil do Rio Mucugezinho é caracterizado por uma sedimentação inicialmente costeira, passando progressivamente para o topo para sistemas fluviais e culminando com o sistema estuarino distal-marinho ("Mengão"). Esse intervalo eqüivale a um grande ciclo transgressivo-regressivo.

\section{PERFIL DO RIO RIBEIRÃO}

O Rio Ribeirão nasce no alto da Serra do Sincorá e é dividido em Ribeirão de Cima (cabeceira), do Meio e de Baixo (foz). Apresenta inúmeras quedas d'água, sendo a mais famosa a Cachoeira do Sossego localizada no Ribeirão de Cima onde o perfil elaborado tem início. No perfil do intervalo inferior levantado no Rio Ribeirão de Cima e do Meio não foi possivel ver a base da Formação Tombador. O perfil levantado, com mais de $180 \mathrm{~m}$ de espessura iniciamse na Cachoeira do Sossego (Fig.VI.6-A). Foram reconhecidos sete intervalos de associações faciólogicas da base para o topo: fluvial- estuarina, estuarina-marinha, fluvialmarinha, deltaica-marinha, fluvial costeira, fluvial e eólica. Quatro seqüências foram identificadas nesse perfil, cujo o quadro é apresentado a seguir:

\begin{tabular}{|l|l|l|l|}
\hline Arenito & Eólico & LS & TSMB \\
\hline Arenito & Fluvial & TSMB \\
\hline Arenito & Fluvial costeiro & LS & TST \\
\hline Arenito e siltito & Deltaico/marinho & & \\
Arenito & Fluvial-marinho & TSMB \\
\hline Arenito e siltito & Estuarino-marinho & TST \\
Arenito & & & TSMB \\
\hline
\end{tabular}


Figura VI.6. Perfil do intervalo inferior do Rio Ribeirão.

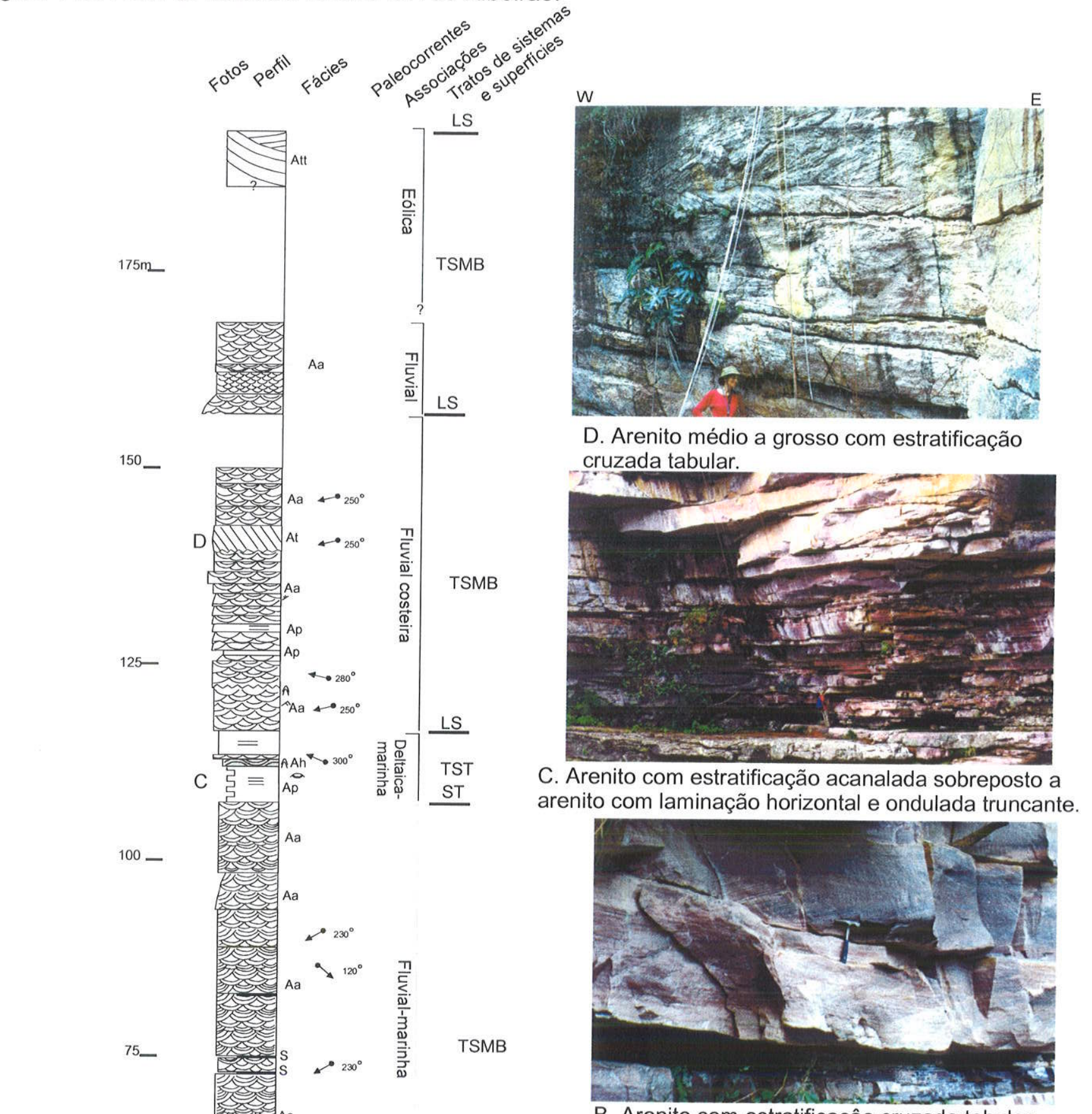

B. Arenito com estratificaçâo cruzada tabular e espinha-de-peixe sobreposto a tempestito.

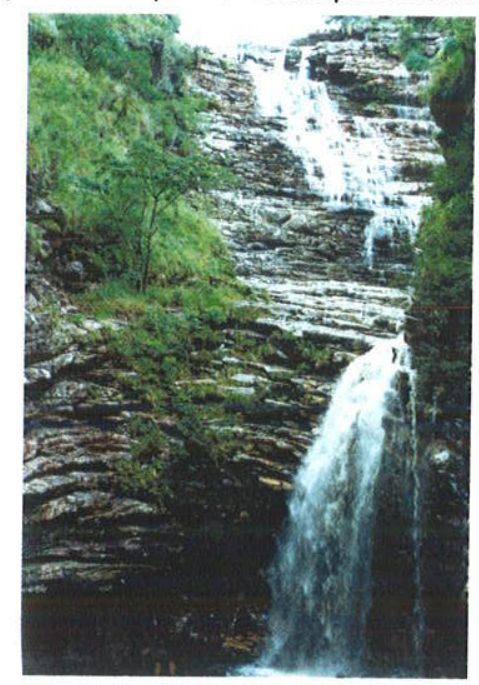

A. Arenitos fluviais e estuarinos (Cachoeira do Sossego). 
A primeira associação encontrada na base do perfil é representada por elementos fluviais e raramente estuarinos; arenitos com estratificações cruzada acanalada com paleocorrentes para sudoeste, intercalados com sedimentos com retrabalhamento por ondas e marés. Essa associação foi depositada num trato de sistemas de mar baixo (TSMB) sendo transgredido no topo por um espesso pacote de siltito marcando a primeira superfície transgressiva. A associação seguinte, estuarina-marinha, apresenta canais com arenitos com estratificação cruzada tabular e sigmóide intercalados com siltitos e arenitos finos marinhos com microestratificações e laminações onduladas truncantes (Figs. V.14 e VI.6-B). Evidências da atuação de marés e ondas, como flaser, laminação por onda e herringbone, são freqüentes nos arenitos canalizados (Fig.VI.6-B). Essa associação encontra-se inserida num trato de sistemas transgressivo (TST).

A seguir um rebaixamento do nível do mar é responsável pela deposição de arenitos fluviais, com intercalações raras de siltito marinho, inseridos num trato de sistemas de mar baixo (TSMB). Segue uma progradação de arenitos laminados deltaicos intercalados com arenitos com estratificação hummocky (tempestitos) inseridos num trato de sistemas transgressivo (Fig.VI.6-C).

Novamente um rebaixamento do nivel do mar leva à formação de uma discordância na base de arenitos fluviais e costeiros, trato de sistemas de mar baixo (TSMB). A seguir ocorrem arenitos fluviais associados a novo rebaixamento (Fig.VI.6-D) sobrepostos por arenitos eólicos(dunas) inseridos num trato de sistemas de mar baixo.

Concluindo, no perfil foram identificadas quatro seqüências deposicionais. A base da primeira seqüência, provavelmente posicionada no contato com a Formação Guiné, conforme observado no perfil do Morro do Pai Inácio, não foi vista. Essa seqüência é composta das associações fluvial estuarina (TSMB) seguida de estuarina-marinha (TST). A seqüência seguinte é caracterizada por associações fluvial-marinha (TSMB) e deltaica-marinha (TST). Na terceira seqüência ocorre a associação fluvial costeira (TSMB), e por fim a última seqüência inicia-se com uma sucessão fluvial seguida de eólica (TSMB). O limite desta última é marcado por uma discordância sobreposta por uma associação leque aluvial (intervalo superior do perfil do Rio Ribeirão).

\section{VI.3. SEÇÃO ESTRATIGRÁFICA DO INTERVALO INFERIOR}

A seção estratigráfica (Fig. VI.7) do intervalo inferior da Formação Tombador foi elaborada a partir da correlação dos perfis dos rios Mucugezinho e Ribeirão. O datum utilizado para a correlação entre os perfis foi a base do primeiro conglomerado, do intervalo superior da 
Figura VI.7. Seção estratigráfica do intervalo inferior, Rio Mucugezinho e Rio Ribeirão.

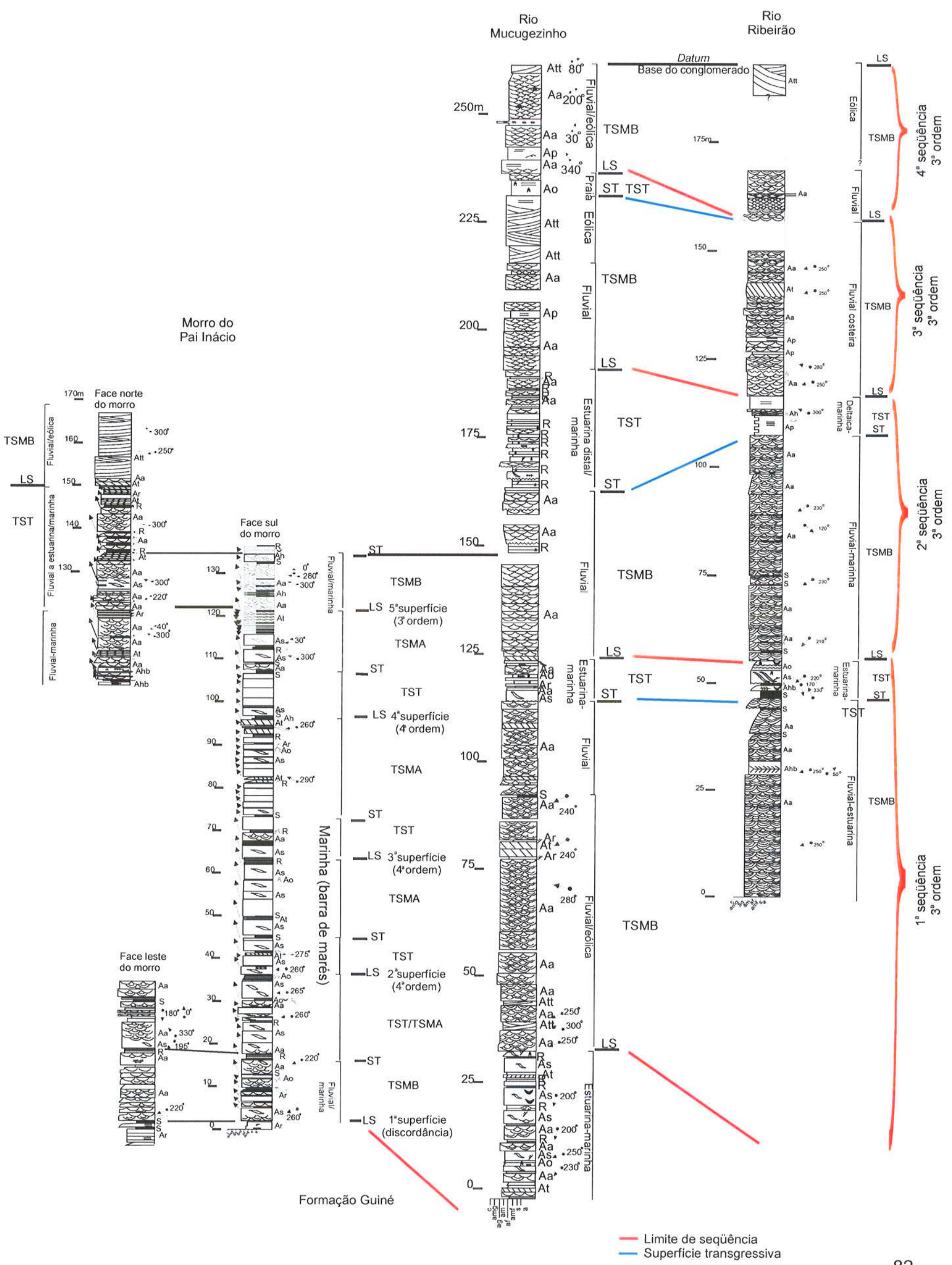


Formação Tombador. Importantes superfícies transgressivas foram importantes na correlação dos dois perfis.

Foram identificadas nesta seção cinco seqüências, possivelmente de $3^{\text {a }}$ ordem. Os limites das primeira e segunda seqüências não foram vistos no perfil do Rio Ribeirão, uma vez que o perfil deste posicionamse mais distante da base da Formação Tombador, sendo portanto menos espesso e mais incompleto que o perfil do Rio Mucugezinho.

Ambos os perfis não alcançaram o contato com a Formação Guiné. O topo da primeira seqüência é observado apenas no perfil do Rio Mucugezinho. Tratam-se de sedimentos estuarinos-marinhos, inseridos no trato de sistemas transgressivo, muito provavelmente posicionado pouco acima do limite da primeira seqüencia vista no Morro do Pai Inácio, que corresponde ao contato entre as formações Guiné e Tombador.

A segunda seqüência é constituída por sistema fluvial com raras intercalações estuarinas-marinhas, provavelmente inserido num trato de sistemas de mar baixo.

A seguir implantou-se um sistema amplamente estuarino com a presença de canais preenchidos por arenitos com estratificação sigmóide, intercalados com arenitos com estratificação cruzada, espinha-de-peixe, contendo flaser, e com arenitos finos e siltitos retrabalhados por ondas de tempestade. Nota-se muito claramente um padrão transgressivo para o topo (TST).

Um novo rebaixamento do nivel do mar culmina na formação de uma nova seqüência composta na base por um expressivo pacote de sedimentos fluviais e raramente costeiros na base (TSMB) sucedidos por uma nova superficie transgressiva. O trato de sistemas transgressivo é bem evidente, caracterizado pela presença de ritmitos arenito/siltito intercalados com arenitos com estratificação cruzada, retrabalhados por ondas (estuarina/marinha), passando lateralmente para sul para arenitos com estratificação ondulada truncante hummocky (tempestitos) e arenitos finos com laminação horizontal (deltaicos).

A quarta seqüência consiste de sistema fluvial a eólico tornando-se mais costeiro em direção a sul (TSMB). No perfil do Rio Mucugezinho há uma importante superficie transgressiva na base de arenitos praiais/litorâneos (TST), desaparecendo lateralmente para o sul.

Finalmente a última seqüência é composta por sistemas fluvial e eólico, possivelmente posicionados dentro de um trato de sistemas de mar baixo (TSMB).

De um modo geral, a seção mostra na base uma disputa entre sistemas fluviais costeiros e estuarinos/marinhos, sem mudanças bruscas de fácies cedendo lugar gradativamente a sistemas fluviais e eólicos, ou seja, há um grande rebaixamento do nível do mar, induzindo a bacia a uma fase mais continental. 


\section{VI.4. INTERVALO SUPERIOR}

\section{PERFIL DO RIO MUCUGEZINHO}

O intervalo superior do perfil do Rio Mucugezinho é bem distinto do intervalo inferior, caracterizado por extensa e monótona sedimentação flúvio-costeira. O intervalo superior é marcado por quatro episódios de soerguimento que resultaram na formação de sistemas de leques aluviais intercalados com sistemas fluviais, eólicos, e litorâneos, sucedidos pelo "Mar Caboclo".

O perfil, com mais de 250 metros de espessura, foi levantado em afloramentos junto ao leito do rio e na rodovia BR-242. Compreende as seguintes associações faciólogicas; leque aluvial, fluvial, eólica, praia, fluvial/estuarina e marinha shoreface. Foram identificadas cinco seqüências nesse perfil.

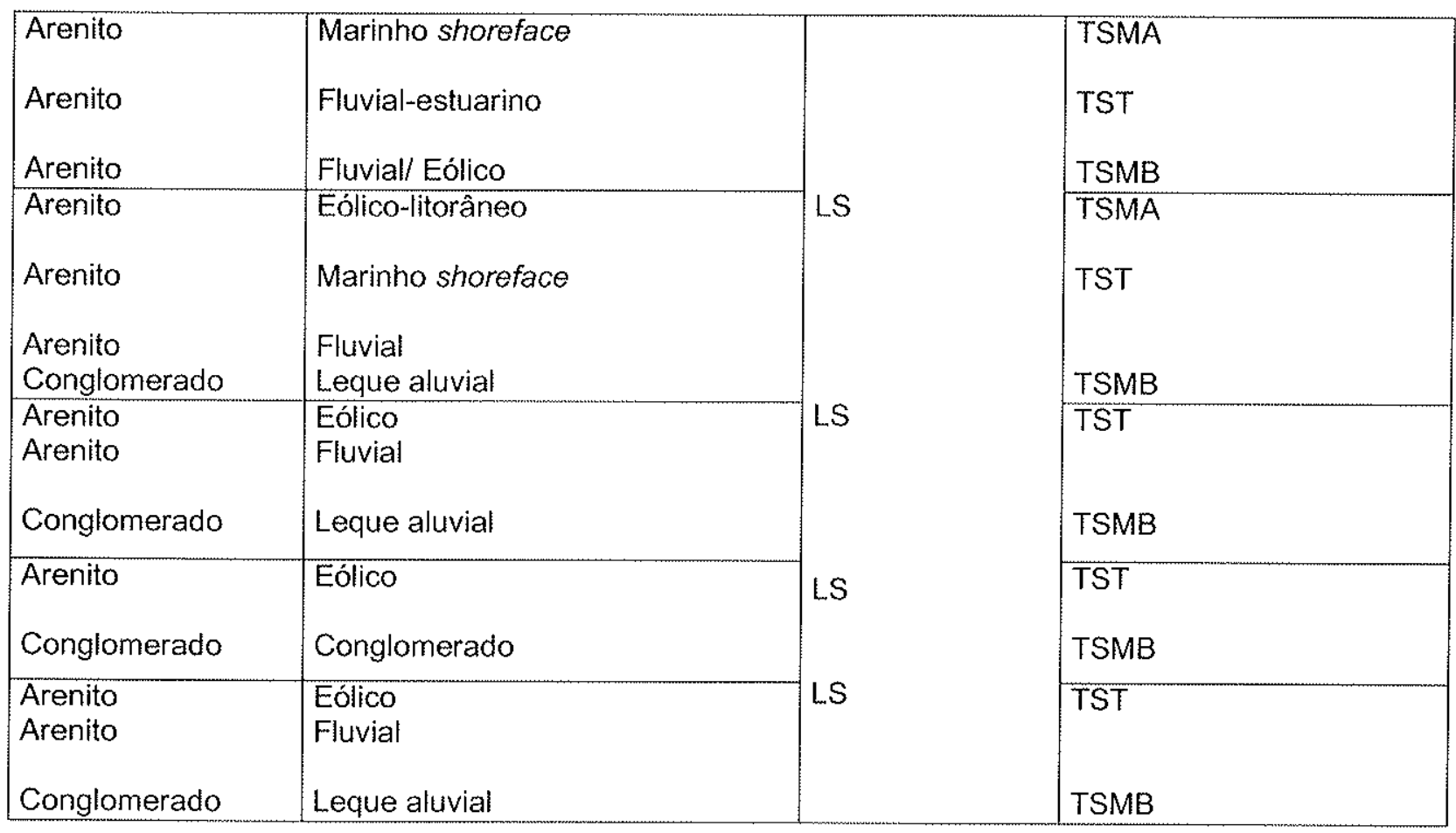

A primeira seqüência inicia com uma discordância na base de canais de conglomerados formados em rios entrelaçados cascalhentos de sistemas de leques aluviais (Fig. VI.8-A), inseridos num trato de sistemas de mar baixo (TSMB). A seguir observa-se uma superfície transgressiva posicionada na base de um espesso intervalo de arenitos eólicos e fluviais intercalados, caracterizando provavelmente um trato de sistemas transgressivo.

Sobreposto a esse sistema eólico ocorre novamente um levantamento tectônico, formação de leques aluviais e deposição de conglomerados (Fig. VI.8-B), trato de sistemas de 
Figura VI.8. Perfil do intervalo superior do Rio Mucugezinho.
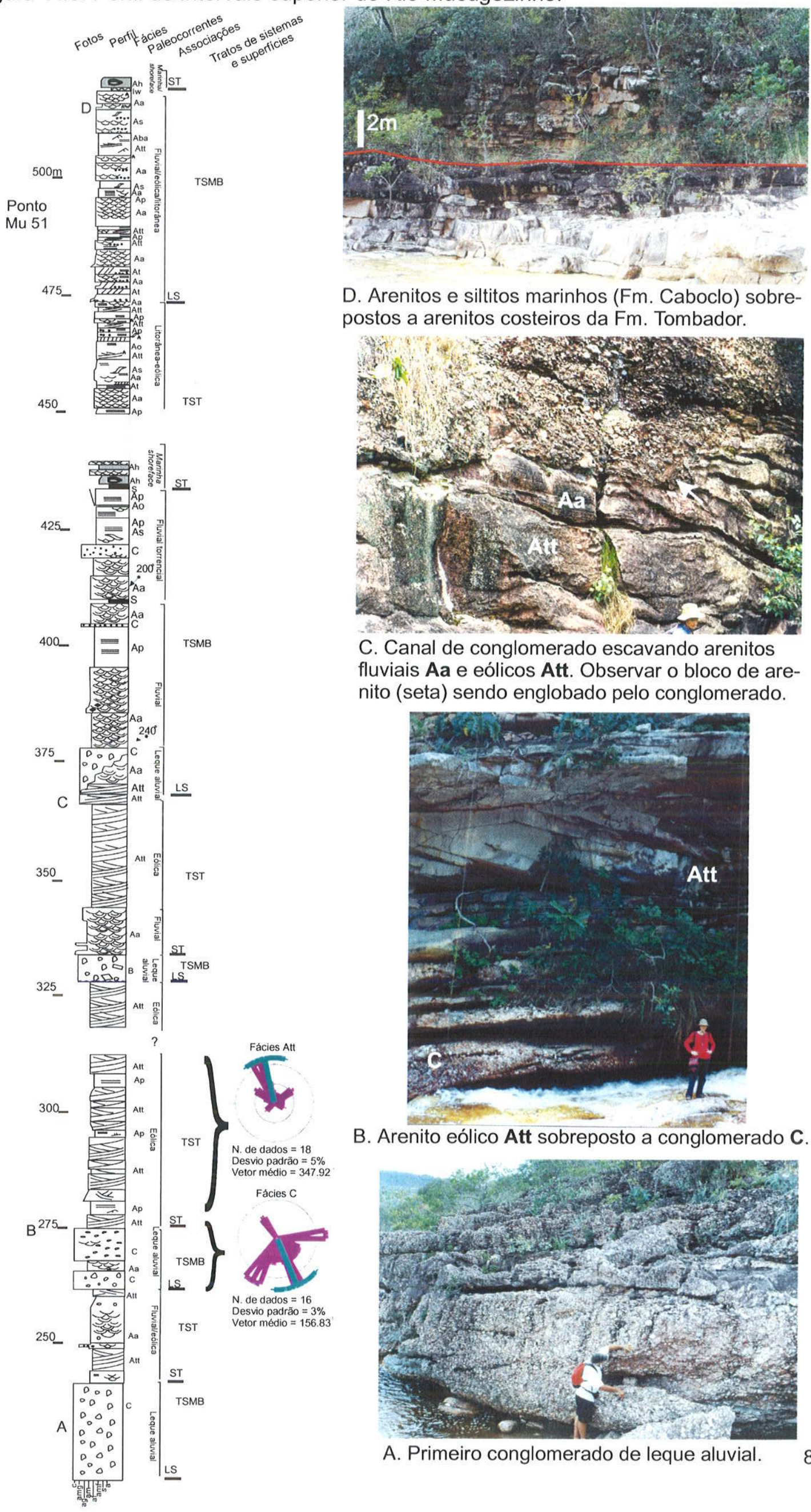

D. Arenitos e siltitos marinhos (Fm. Caboclo) sobrepostos a arenitos costeiros da Fm. Tombador.

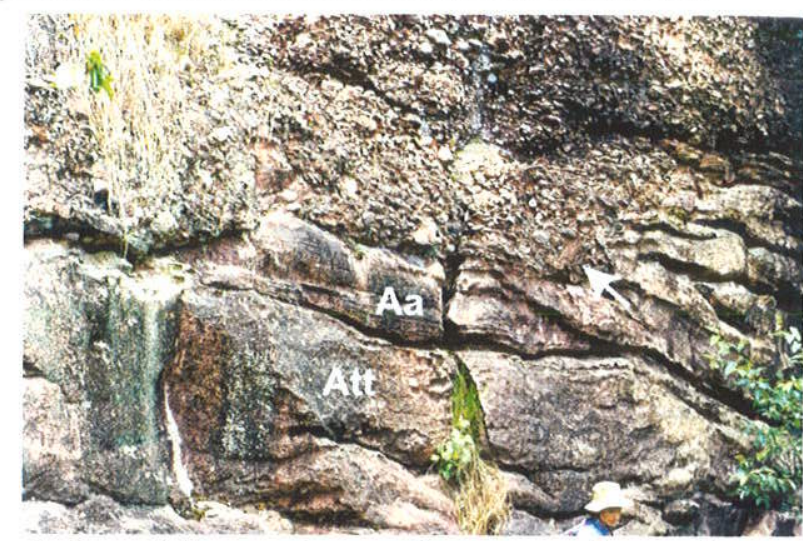

C. Canal de conglomerado escavando arenitos fluviais Aa e eólicos Att. Observar o bloco de arenito (seta) sendo englobado pelo conglomerado.

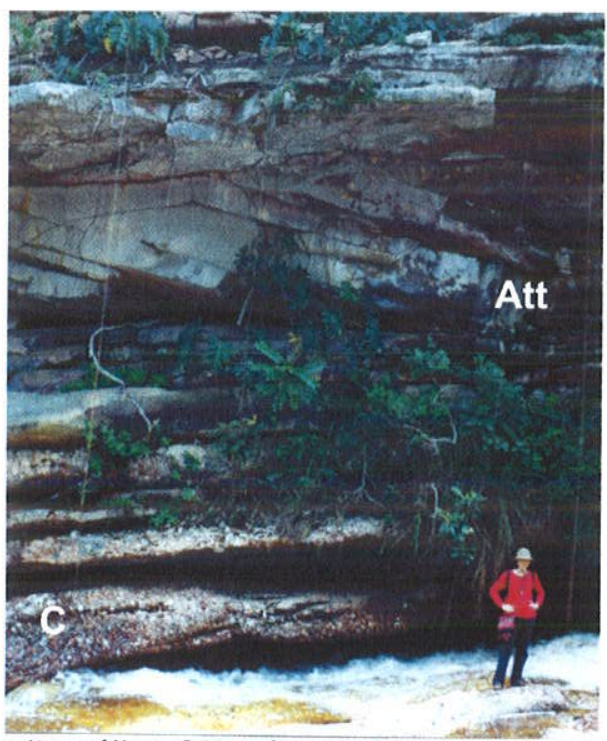

B. Arenito eólico Att sobreposto a conglomerado C.

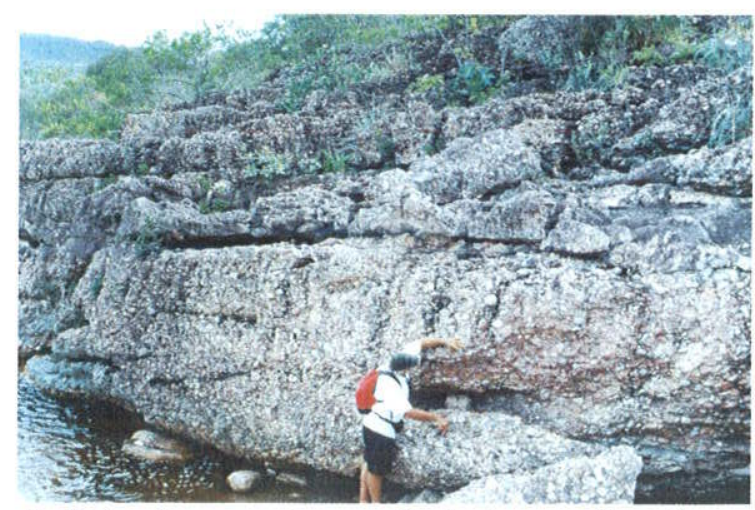

A. Primeiro conglomerado de leque aluvial. 
mar baixo. Imbricação de clastos e estratificações cruzadas mostram paleocorrentes para sudeste. Acima da associação de leque ocorre novamente intercalação de sistemas eólicos e fluviais (TST). O fluxo do vento era para norte, conforme medido nas estruturas.

A terceira seqüência é semelhante à primeira e à segunda, com sistema de leque aluvial (brechas) na base (TSMB) seguido de sistemas fluviais e eólicos.

A seguir tem-se o último ciclo do intervalo superior da Formação Tombador, descrito em detalhe no capítulo seguinte. A base da seqüência deste último ciclo evidencia de forma clara a auto-canibalização da bacia. O conglomerado desenvolvido no sistema de leque aluvial erode o material sotoposto, arenitos eólico e fluvial litificados, e englobam os blocos em sua matriz (Fig. VI.8-C). A associação de leque é sucedida pelas associações fluvial, fluvial torrencial que são transgredidos por arenitos finos com laminação horizontal e cruzada por ondas, siltito e tempestito formados num trato de sistemas transgressivo (TST). Sucedem sistemas litorâneo, fluvial e eólico para o topo (TSMA).

Por fim, a quinta e última seqüência do intervalo superior é caracterizada por sistemas fluvial e eólico (TSMB) seguidos de fluvial-estuarino (TST) transgredidos por sistemas marinhos plataformais retrabalhados por ondas de tempestade da Formação Caboclo, inseridos possivelmente num trato de sistemas mar alto (Fig. VI.8-D).

\section{PERFIL DO RIO RIBEIRÃO}

O perfil do intervalo superior do Rio Ribeirão foi levantado nos trechos conhecido como ribeirões do Meio e de Baixo. Apresenta mais de $180 \mathrm{~m}$ de espessura, compreendendo seis intervalos de associações faciólogicas; leque aluvial, fluvial, eólica, marinha/frente deltaica, planície deltaica/marinha, fluvial estuarina e marinha shoreface. Cinco seqüências foram identificadas nesse perfil. 


\begin{tabular}{|l|l|l|l|}
\hline Arenito & Marinho shoreface & & TSMA \\
Arenito & Fluvial-estuarino & LS & TST \\
Arenito & Fluvial/ Eólico & TSMB \\
\hline Arenito & Planície deltaica/marinho & TSMA \\
Arenito & Marinho/frente deltaica & TST \\
Arenito & Fluvial & & \\
Conglomerado & Leque aluvial & Lólico costeiro & TSMB \\
\hline Arenito & Fluvial/eólico & TST \\
Arenito & Eólico & TSMB \\
\hline Arenito & Conglomerado & TS & TSMB \\
Conglomerado & Eólico & TST \\
\hline Arenito & Leque aluvial & TSMB \\
\hline Conglomerado & & \\
\hline
\end{tabular}

O perfil inicia-se com conglomerados formados em rios entrelaçados cascalhentos em sistemas de leques aluviais, inseridos em um trato de sistemas de mar baixo (TSMB), onde na base desse pacote foi reconhecido um limite de seqüências. A seguir foi identificada uma superficie transgressiva na base de sistemas fluvial passando a eólico, relacionados a um trato de sistemas transgressivo (TST).

A segunda seqüência é caracterizada por uma discordância na base, formada em resposta a um novo soerguimento tectônico induzindo à formação de sistemas aluviais (conglomerados e arenitos conglomeráticos), trato de sistemas de mar baixo (Fig.VI.9-A). Novamente ocorre um espesso pacote de sedimentos eólicos (dunas e interdunas), com paleocorrentes para norte/noroeste, inseridos num trato de sistemas transgressivo (TST).

A terceira seqüência apresenta na base sistemas fluvial e eólico intercalados dentro de um trato de sistemas de mar baixo (TSMB). As paleocorrentes do sistema fluvial apresentam sentido para sul/sudeste. A base do trato de sistemas transgressivo a seguir é caracterizado por uma superfície transgressiva marcada por uma espessa camada de ritmitos arenito/siltito com evidências de ondas intercalados para o topo com arenitos eólicos. Trata-se de um sistema eólico costeiro devido à intercalação com os sedimentos retrabalhados por ondas.

A seguir tem-se o último ciclo do intervalo superior da Formação Tombador, descrito em detalhe no capítulo seguinte. Este ciclo inicia-se com um novo soerguimento promovendo a formação de leques aluviais levando à deposição de 20 metros de espessura de conglomerados e brechas (Fig.VI.9-B), sobrepostos por arenitos fluviais com paleocorrentes preferencialmente para sul. Os conglomerados e as brechas escavaram, fraturaram e englobaram arenitos eólicos sotopostos (Fig.VI.9-C) já litificados, na sua matriz, evidenciando um limite de seqüências (TSMB). Esses depósitos foram sucedidos por uma transgressão, 
Figura VI.9. Perfil do intervalo superior do Rio Ribeirão.

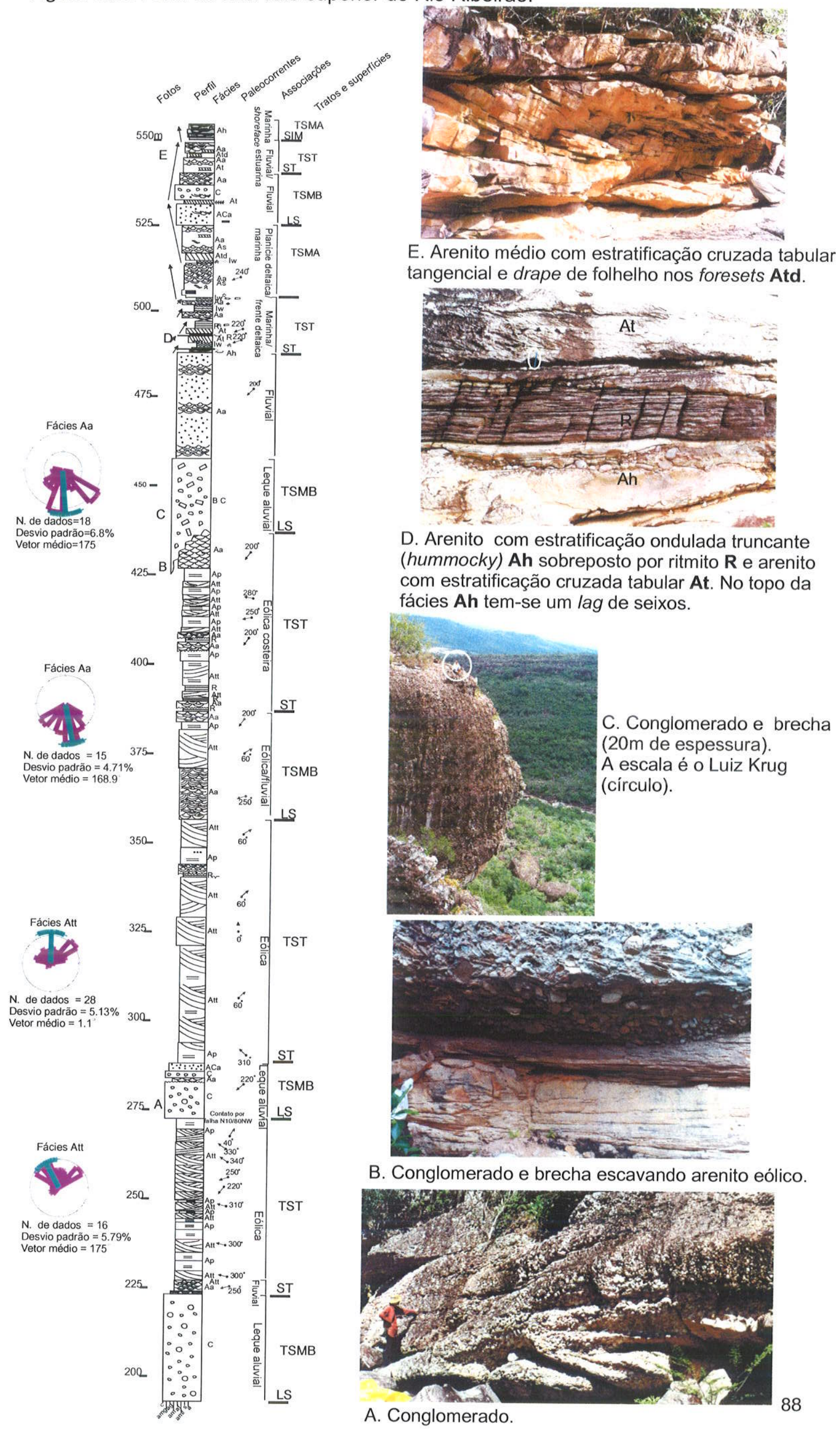


caracterizada pela deposição de interlaminações arenito/siltito (wavy), ritmitos, associados a arenitos com estratificação ondulada truncante (hummocky) (tempestitos) e arenitos com estratificação cruzada tabular (Fig.VI.9-D) (associação marinha/frente deltaica). Esta última associação representa um trato de sistemas transgressivo (TST). Acima ocorre uma superfície de inundação marinha seguida de progradação de arenitos deltaicos intercalados com sedimentos marinhos retrabalhados por ondas e marés, posicionados num trato de sistemas de mar alto (TSMA).

Finalmente a quinta e última seqüência apresenta as associações fluvial (TSMB), estuarina (TST) (Fig.VI.9-E), seguida de uma inundação marinha e deposição de sedimentos marinhos plataformais (shoreface), predominantemente tempestitos, inseridos num trato de sistemas de mar alto, marcando a passagem para a Formação Caboclo sobrejacente.

\section{VI.5. SEÇÃO ESTRATIGRÁFICA DO INTERVALO SUPERIOR}

A seção estratigráfica (Fig. VI.10) do intervalo superior da Formação Tombador foi elaborada a partir da correlação dos perfis do intervalo superior dos rios Mucugezinho e Ribeirão. O datum utilizado foi uma importante superficie transgressiva do último ciclo do intervalo superior da Formação Tombador.

Foram identificadas nesta seção quatro seqüências de $3^{\text {a }}$ ordem e uma seqüência de $4^{a}$ ordem.

A primeira seqüência é formada na base uma discordância formada em resposta a um soerguimento tectônico. Com o soerguimento desenvolveram-se sistemas de leque aluvial originando conglomerados depositados numa fase de mar baixo (TSMB). Neste caso, o espaço de acomodação foi gerado fundamentalmente em função da tectônica, provavelmente num intervalo de tempo menor que quando comparado ao espaço criado em função da subida do nível do mar. Talvez por isso não se observa um conjunto de parasseqüências progradantes e sim, um padrão em "caixa" do conjunto. Sendo assim, quando a tectônica exerce um papel maior do que o nivel do mar, é apropriado chamar de tectonosseqüência (Castro et al. 2001). As tectonosseqüências identificadas são possivelmente de $3^{\text {a }}$ ordem, com caráter alogênico, favorecendo abruptas mudanças nas taxas de acomodação.

Acima do sistema de leque se desenvolveram sistema fluvial e eólico intercalados, inseridos possivelmente num trato de sistemas transgressivo (TST).

A segunda seqüência é semelhante a primeira, difere apenas que a espessura dos sistemas fluvial e eólico intercalados aumenta enquanto a espessura do sistema de leque diminui. A seção mostra também que provavelmente esses sistemas são mais antigos ao sul da área (perfil do Rio Ribeirão). 
Figura VI.10. Seção estratigráfica do intervalo superior, Rio Mucugezinho e Rio Ribeirão.

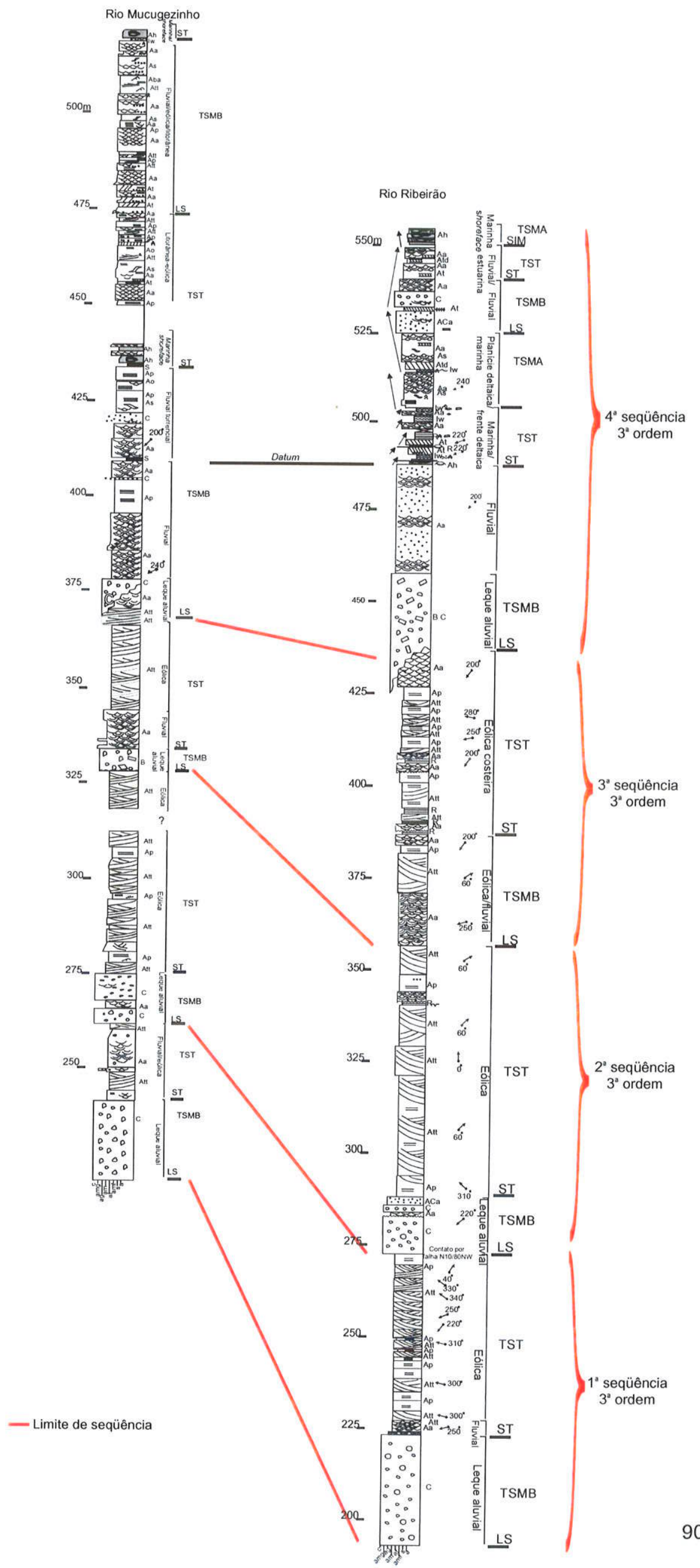


O limite da terceira seqüência, no perfil do Rio Mucugezinho, ocorre na base de conglomerados que passam lateralmente em direção ao Rio Ribeirão para arenitos fluviais (TSMB). Sobreposta há uma superfície transgressiva caracterizada pela intercalação de sistemas eólico e fluvial (Rio Mucugezinho) passando lateralmente a um sistema eólico costeiro (Rio Ribeirão). As estruturas evidenciam a proximidade da costa nesse perfil.

A base da quarta seqüência é marcada por canais profundos preenchidos por conglomerados e brechas, escavando arenitos eólicos e fluviais sotopostos. O sistema de leque passa para um sistema fluvial (TSMB) e gradativamente cede lugar a sistemas marinho e deltaico (TST).

No perfil do Rio Mucugezinho foi identificado um limite de seqüência, possivelmente de $4^{\mathrm{a}}$ ordem, na base de um sistema fluvial, que passa lateralmente a um sistema deltaico (Rio Ribeirão), representando possivelmente uma concordância correlata. A seguir desenvolveu-se um sistema costeiro a norte (Rio Mucugezinho) passando lateralmente para o sul para um sistema deltaico.

Finalmente, no topo da seção ocorre um sistema fluvial, com forte influência da ação das marés, inserido num trato de sistemas transgressivo. Sobreposta ocorre uma transgressão marinha culminando na formação de um sistema marinho shoreface, fortemente dominado por ondas de tempestade, também conhecida de transgressão do "Mar Caboclo", inserido possivelmente num trato de sistemas de mar alto.

A distribuição dos conglomerados pela área pode ser observada no mapa da figura VI.11. 
Figura VI.11. Mapa dos afloramentos descritos mostrando a distribuição dos quatro níveis de conglomerado.
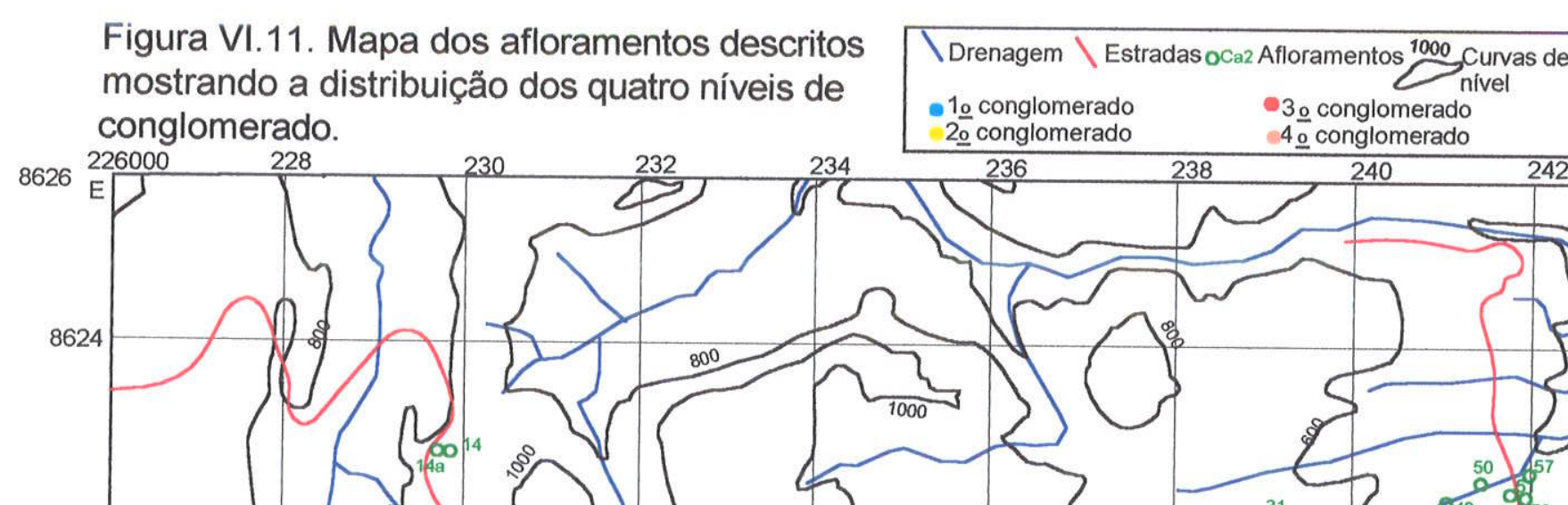


\section{O ULTIMO CICLO DO INTERVALO SUPERIOR, FORMACAO TOMBADOR}

\section{VII.1. INTRODUÇÃO}

Neste capítulo serão apresentas as sucessões bem detalhadas apenas do topo do intervalo superior da Formação Tombador através de perfis estratigráficos elaborados inicialmente na escala 1:500.

No perfil do rio Mucugezinho foram reconhecidos quatro grandes ciclos, ou seqüências, cada um iniciando com espessa seção de conglomerados e brechas; o ciclo mais novo, informalmente designado "último ciclo", é limitado superiormente pelos depósitos marinhos da Formação Caboclo, e será caracterizado a seguir, por meio de levantamento e correlação de quatro perfis nos rios Capivara, Ribeirão, Lençóis e Mucugezinho.

\section{VII.2. PERFIS ESTRATIGRÁFICOS}

\section{PERFIL DO RIO CAPIVARA}

O Rio Capivara está localizado a cerca de $9 \mathrm{~km}$ de Lençóis em direção à Andaraí (sul). É nesse rio que se encontra a Cachoeira da Fumaça, uma das mais altas da Chapada.

O perfil levantado no curso final do Rio Capivara apresenta uma excelente exposição do último ciclo, exceto quanto a presença de depósitos costeiros e eólicos (do topo do ciclo) somente na margem direita, enquanto na margem esquerda os mesmos depósitos podem estar ausentes por falhamento.

A coluna apresentada pelo último ciclo consta de oito sistemas deposicionais conforme o quadro abaixo:

\begin{tabular}{|l|l|l|}
\hline 8 & Arenito e Siltito & Marinho (Formação Caboclo) \\
\hline 7 & Arenito & Costeiro e eólico \\
\hline 6 & Arenito & Fluvial \\
\hline 5 & Arenito e Siltito & Frente deltaica \\
\hline 4 & Arenito & Fluvial \\
\hline 3 & Arenito e Siltito & Marinho de tempestade (com brecha) \\
\hline 2 & Brecha e Arenito & Leque subaquoso \\
\hline 1 & Conglomerado e Brecha & Leque aluvial \\
\hline
\end{tabular}


O perfil do último ciclo, no rio Capivara, tem inicio com espesso pacote (superior a $20 \mathrm{~m}$ ) de conglomerado e brecha, atribuido a leque aluvial (Fig. VII.1). A fácies de brecha pode ser individualizada na parte superior deste perfil, conforme mostrado anteriormente na figura V.2-C; tal fácies mostra um aspecto caótico ou organizado, neste caso com imbricação dos calhaus (Figs. V.2-B e VII.1-A).

O segundo sistema, com espessura de $11 \mathrm{~m}$, é formado por estratos, de escala métrica, de brecha gradando a arenito com laminação paralela ou ondulada (truncante?) (Fig. V.3); sua organização e posicionamento estratigráfico (transição entre leque aluvial e marinho) sugere um ambiente de leque subaquoso raso.

O terceiro sistema é marinho raso, podendo ser dividido em duas partes: arenitos e siltitos (tempestitos distais) e arenitos amalgamados (tempestitos proximais), com espessuras de $12 \mathrm{~m}$ e $6 \mathrm{~m}$, respectivamente.

A primeira associação consiste de estratos gradacionais de arenito a siltito, com espessura dos sets variando de milimetros (siltito) a $2,5 / 5 \mathrm{~cm}$ (wavy ou ritmito delgado), $20 \mathrm{~cm}$ (microhummocky) e $1 \mathrm{~m}$ (ver Fig. V.19). Tais fácies dispõe-se verticalmente em arranjos de espessamento estratal seguido de adelgaçamento (Fig. VII.1), indicativos de arrasamento seguido de aprofundamento. É marcante a presença de tempestitos "brechados" nesta associação, principalmente na margem esquerda do Capivara (ver Figuras V.20 e V.21, e Fig. VII.1-B), sendo inevitável a sua comparação com os "tempestitos grossos" descritos no Paleozóico da Bacia do Paraná (Castro et al. 2001), onde cada estrato mostra passagem de depósitos tracionais (arenitos grossos, mas SEM calhaus/cobbles) para fluxos oscilatórios.

Um novo arranjo de espessamento ascendente se observa na passagem para a segunda associação, de arenitos amalgamados (Fig. VII.1). Os estratos, de escala métrica, apresentam individualmente passagem gradacional de estratificação cruzada para laminação paralela a ondulada truncante, e são interpretados como tempestitos proximais, mais rasos.

Em passagem brusca sobre a fácies anterior, ocorre o quarto sistema: um pacote, com mais de $6 \mathrm{~m}$ de espessura, de arenito com estratificação cruzada acanalada e rara tabular, e laminação plano-paralela a cruzada, de provável origem fluvial. A ocorrência de um pequeno intervalo com laminação ondulada truncante aponta para um retrabalhamento marinho local.

O quinto sistema é espesso (acima de $20 \mathrm{~m}$ ) e texturalmente mais fino que as vizinhos: são arenitos finos intercalados com siltitos, mostrando laminações plano-paralelas nãodeformadas ou estratos deformados como marcas de carga (possivelmente load ripples) (Fig. 
Figura VII.1. Perfil do Rio Capivara.
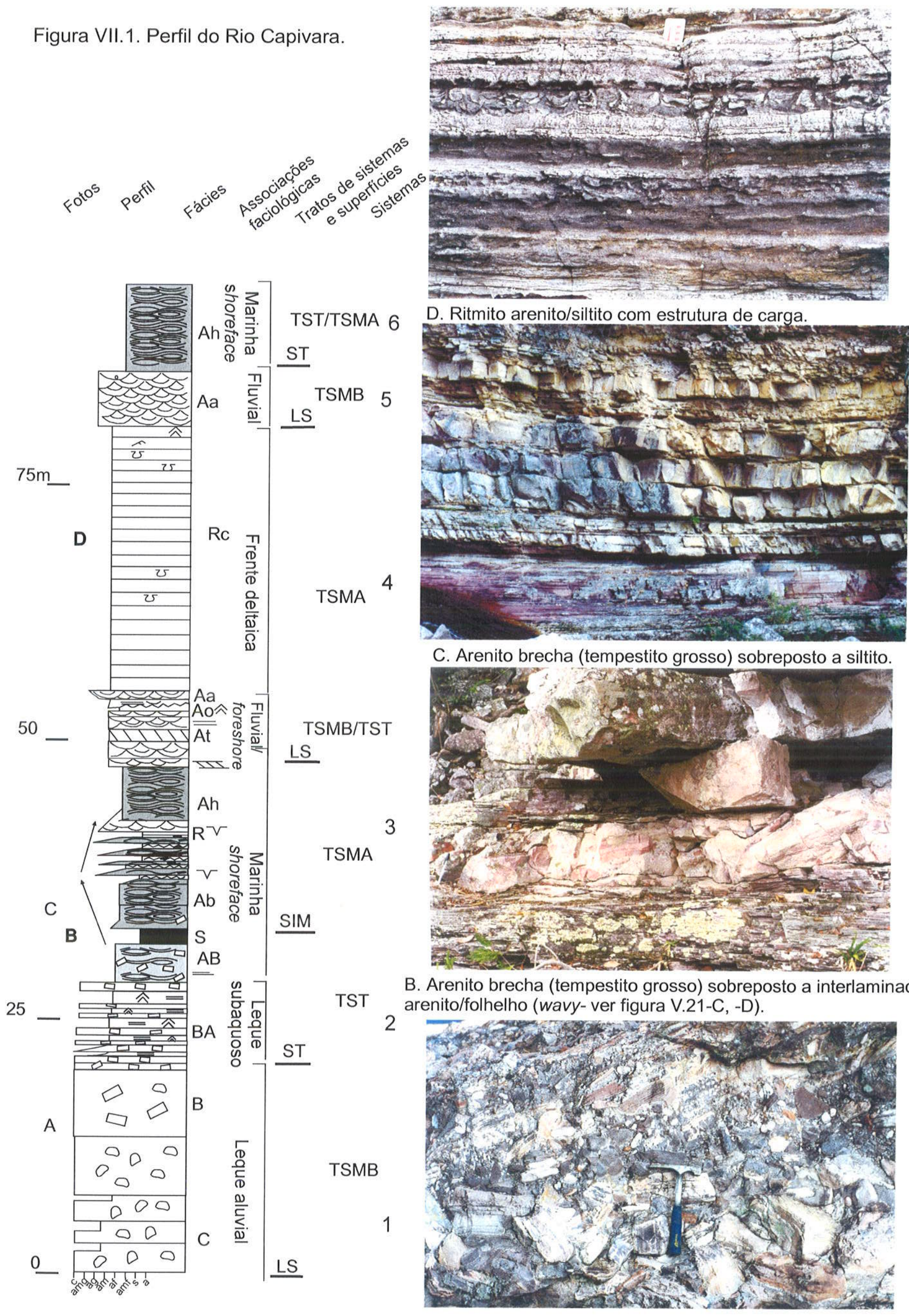

A. Brecha e seixos de quartzito e arenito. Clastos imbricados para a esquerda (oeste), em matriz seixosa (parte superior). 
VII.1-D; ver Fig. V.11). Tais processos de suspensão podem indicar um ambiente de frente deltaica, por alguma razão (sismos?) bastante instabilizado.

No sexto sistema predominam arenitos com estratificação cruzada acanalada, provavelmente indicando um retorno à condições mais fluviais.

O sétimo sistema só foi observado na margem direita do rio, e é formado por associações costeira e eólica. Os arenitos costeiros, com $3 \mathrm{~m}$ de espessura, consistem de estratos cruzados acanalados a sigmoidais, com paleocorrentes em dois sentidos, $0^{\circ} / 30^{\circ} \mathrm{e}$ $180^{\circ} / 200^{\circ}$ (NNE e SSO), sugerindo a ação de correntes de marés. Os arenitos eólicos sobrepostos, com espessura alcançando $13 \mathrm{~m}$, mostram estratos cruzados do tipo tabulartangencial de tamanho métrico e orientação média para NE (entre $10^{\circ}$ e $80^{\circ}$ ).

O oitavo sistema, bem ilustrado na margem esquerda do rio em afloramento de $8 \mathrm{~m}$ de espessura, é dominado por estratos marinhos de tempestades, e já corresponde à Formação Caboclo (Fig. VII.1).

\section{PERFIL DO RIO RIBEIRÃO DE BAIXO}

O Rio Ribeirão de Baixo mostra o mais completo perfil levantado para o último ciclo do intervalo superior da Formação Tombador. Com um total de $110 \mathrm{~m}$ de espessura, o perfil pode ser dividido em sete sistemas deposicionais, cujo arranjo seqüencial pode ser visto no quadro abaixo (o sétimo sistema, marinho, já faz parte da Formação Caboclo):

\begin{tabular}{|l|l|l|}
\hline 7 & Arenito e Siltito & Marinho (Formação Caboclo) \\
\hline 6 & Arenito & Fluvial e eólico (?) \\
\hline 5 & Arenito a Conglomerado & Fluvial \\
\hline 4 & Arenito e raro Siltito & Planície deltaica e raro marinho \\
\hline 3 & Arenito; Arenito e Siltito & Frente deltaica e marinho \\
\hline 2 & Arenito conglomerático & Fluvial \\
\hline 1 & Conglomerado e Brecha & Leque aluvial \\
\hline
\end{tabular}

O sistema de leque aluvial, na base do perfil, é formado por conglomerados e brechas (Fig. VII.2); estas fácies ocorrem juntas, misturadas, como na base do sistema, onde se observa que os calhaus (brecha) originam-se do retrabalhamento dos arenitos eólicos 
Figura VII.2. Perfil do último ciclo do intervalo superior, Rio Ribeirão de Baixo.

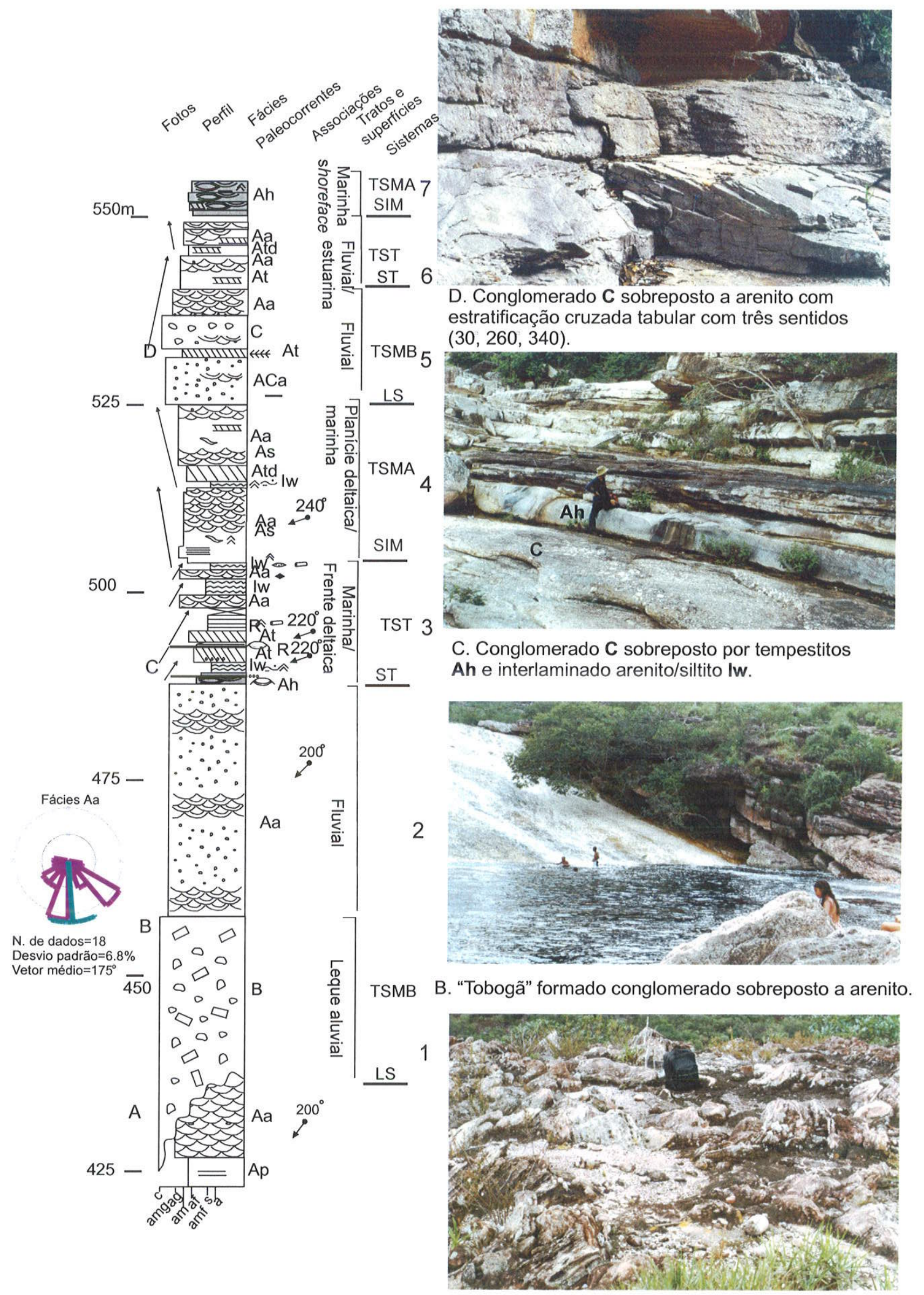

A. Brecha constituída por blocos angulosos de arenito. 
subjacentes (ver Fig. V.2-D). Outras vezes ocorre predomínio de uma ou outra litologia, como na brecha caótica com matacões, revista na Fig. VII.2-A.

O segundo sistema, com quase $30 \mathrm{~m}$ de espessura, é formado por arenito grosso a conglomerático de origem fluvial (Fig. VII.2-B; ver também Fig. V.6-B). Os maiores seixos tem $2,5 \mathrm{~cm}$ a $3 \mathrm{~cm}$ (pebbles), e são geralmente bem arredondados.

As paleocorrentes apontam predominantemente para sul.

Segue-se um sistema marinho de tempestitos distais, correlato ao do Perfil Rio Capivara; no Rio Ribeirão de Baixo, entretanto, tal sistema está associado a corpos de arenito com 1,0m a 1,5m de espessura e com estratificação cruzada tabular e acanalada, orientada para sudoeste $\left(210^{\circ}\right.$ a $\left.235^{\circ}\right)$. O arranjo básico das duas associações é o de granodecrescência ascendente, iniciando com o corpo arenoso apoiado em um substrato erosivo, e afinando para tempestitos marinhos (arenitos amalgamados e arenitos/siltitos em estratos espessos a delgados, e siltitos/ritmitos ou interlaminações wavy). As orientações das cristas das ondas indicam leste-oeste $\left(80^{\circ}-105^{\circ}\right)$ e norte-sul $\left(170^{\circ}-180^{\circ}\right)$.

Essas associações indicam um contexto transicional-marinho, associado a uma frente deltaica episodicamente afogada por tempestades marinhas.

O quarto sistema é formado por dois espessos corpos de arenito, com estratificação cruzada acanalada, tabular e sigmóide e contatos basais erosivos com depósitos do sistema anterior (Fig. VII.2). O corpo inferior está assentado em interlaminação wavy arenito-folhelho, enquanto o superior prograda sobre arenito com estratificação cruzada tabular modificada por marés (paleocorrentes a $80^{\circ}$ e $260^{\circ}$ ) e sobre siltito (ver Fig. V.12). Esse conjunto sugere um contexto flúvio-deltaico, provavelmente de planície deltaica, para os corpos arenosos do quarto sistema.

$\mathrm{Na}$ evolução do perfil do ciclo superior no Rio Ribeirão, sucedem-se dois corpos (espessuras de 6,0 a 7,5m) de arenito muito grosso a conglomerado com estratificação cruzada acanalada e raramente tabular, de origem fluvial (Fig. VII.2). Aqueles corpos estão separados por um arenito médio a grosso com estratificação cruzada tabular, mergulhando para $30^{\circ}, 260^{\circ}$ e $340^{\circ}$, indicando influência de marés em sua deposição (Fig. VII.2-D).

O sexto sistema compreende dois corpos de arenito grosso com estratificação cruzada acanalada e tabular, de origem fluvial, separados por um estrato métrico de arenito com 
estratificação cruzada tabular-tangencial orientada para oeste-sudoeste $\left(240^{\circ}\right)$, de provável origem eólica (Fig. VII.2).

Completam o perfil estratos tabulares $(0,15$ a $0,5 \mathrm{~m}$ de espessura) de arenitos, com estratificação cruzada tabular e laminação plano-paralela ou com estratificação e laminação onduladas truncantes, já ligados ao ambiente marinho transgressivo da Formação Caboclo (Fig. VII.2).

\section{PERFIL DO RIO LENÇÓIS}

O Rio Lençóis, quando deixa as montanhas e flui pelas encostas rochosas em direção à Cidade de Lençóis é conhecido como Serrano. Nele encontram-se grutas e cachoeiras, sendo a Cachoeirinha e Primavera bem conhecidas. Os conglomerados vistos no topo dessas cachoeiras, são correlacionáveis e projetam-se no leito do rio na Cidade de Lençóis.

Este perfil é contínuo em duas áreas do Rio Lençóis, quais sejam no Serrano, com a parte basal (sistemas de leque aluvial e fluvial), e a jusante da ponte dentro da cidade de Lençóis, com a parte superior (sistemas transicional e marinho). Entre essas partes o perfil mostra-se encoberto, numa extensão de uns $400 \mathrm{~m}$, o que obriga a investigar a margem esquerda do rio com certo grau de dificuldade; nesta, dois trechos possibilitam completar o perfil, com uma escarpa de depósitos aluviais, sucedida no trecho rodoviária-Pousada Lavramor por depósitos marinhos e transicionais.

Foram identificados oito sistemas no perfil do Rio Lençóis, conforme a apresentação do quadro seguinte:

\begin{tabular}{|l|l|l|}
\hline 8 & Arenito fino e raro Siltito & Marinho (Formação Caboclo) \\
\hline 7 & Arenito grosso & Estuarino \\
\hline 6 & Arenito conglomerático & Fluvial \\
\hline 5 & Arenito grosso a fino & Planície deltaica \\
\hline 4 & Arenito Siltito & Litorâneo/marinho \\
\hline 3 & Arenito grosso a conglomerático & Fluvial \\
\hline 2 & Arenito grosso & Fluvial \\
\hline 1 & Conglomerado e Brecha & Leque aluvial \\
\hline
\end{tabular}


O sistema de leque aluvial da base do último ciclo ocorre no vale do Rio Lençóis, próximo a cidade (Serrano); também pode ser observado e medido mergulho acima, em cachoeiras de seus afluentes Grisante e Cachoeirinha (neste foram medidos $17 \mathrm{~m}$ de espessura). O sistema sobrepõe-se erosivamente a depósitos eólicos, de onde incorpora grandes clastos na sua porção basal (Fig. VII.3-A). Paleocorrentes mostram uma grande dispersão, entre o sul, oeste e norte (entre $170^{\circ}$ e $360^{\circ}$ ).

Os depósitos fluviais são de arenitos grossos, com níveis conglomeráticos, e predominância de estratificação cruzada acanalada. As paleocorrentes mostram dispersão entre $200^{\circ}$ e $310^{\circ}$ (média de $250^{\circ}$ ), ou seja, entre sul-sudoeste, oeste e noroeste. É importante destacar, quase no topo do afloramento do leito do rio, uma intercalação $(0,4 \mathrm{~m})$ de um arenito muito fino/síltico com laminação cruzada clino-ascendente, orientada aproximadamente para oeste $\left(290^{\circ}\right)$ (Fig. VII.3).

O perfil prossegue em uma escarpa da margem esquerda do rio, onde em sua porção superior destacam-se cerca de $20 \mathrm{~m}$ de arenitos conglomeráticos com abundante estratificação cruzada. A seguir no perfil, uma sucessão granocrescente, com arenitos médios passando a arenitos grossos com estratificação cruzada acanalada.

O quarto sistema, imediatamente recobrindo o anterior, é representado por uns $20 \mathrm{~m}$ de arenitos e siltitos marinhos a costeiros, e que pode ser observado na subida entre a rodoviária e a Pousada Lavramor. Destacam-se laminação horizontal ou estratificação cruzada de baixo ângulo, micro-estratificação e laminação ondulada truncante, bem como estratificação cruzada tabular e sigmóide; estas estruturas, mais a presença de sucessões com granocrescência ascendente, sugerem a ocorrência de depósitos litorâneo ou de frente deltaica progradando sobre o meio marinho (Fig. VII.3). Tal sucessão, também observada no perfil da ponte (Fig. VII.3, ver perfil a $125 \mathrm{~m}$ e foto B), sugere um contexto de fan delta, sob influência de marés. Sucessão semelhante, com progradação de arenitos sigmoidais sobre arenitos com laminações cruzadas por ondas e flasers, foi ilustrada anteriormente (Fig. V.4-B).

O quinto sistema foi identificado no perfil do rio imediatamente sob a ponte, para jusante. Consiste de $12 \mathrm{~m}$ de arenito formando dois corpos separados por nível métrico de arenito com estratificação ondulada truncante. No corpo inferior observam-se estratificações cruzadas acanalada e tabular, e raramente laminações horizontal e cruzada por ondas; no corpo superior predominam as mesmas estratificações, em parte modificadas por marés (espinha-de-peixe, flasers e bundles) (Fig. VII.3-B). O corpo superior, progradando sobre 
Figura VII.3. Perfil do Rio Lençóis.
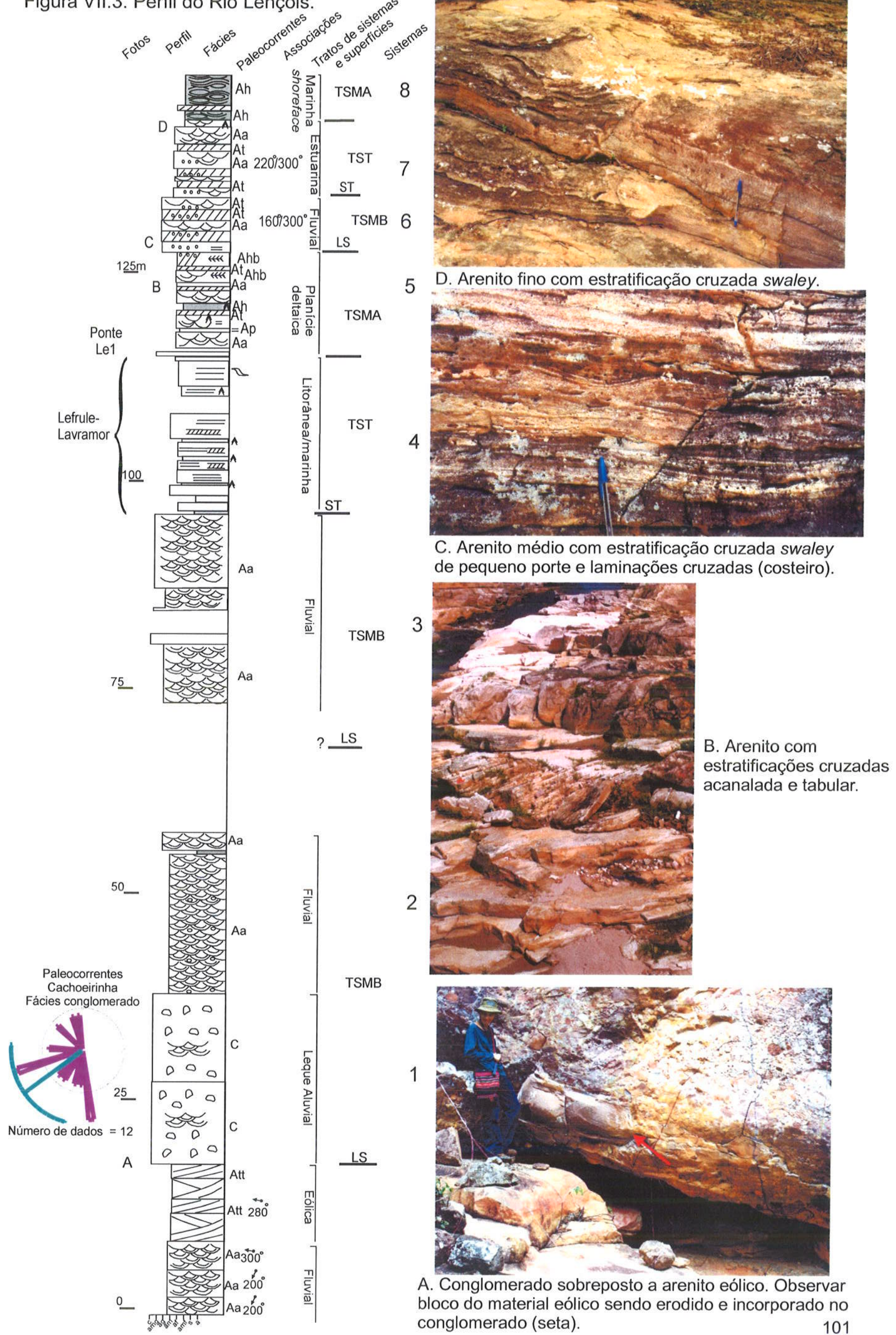

TSMB

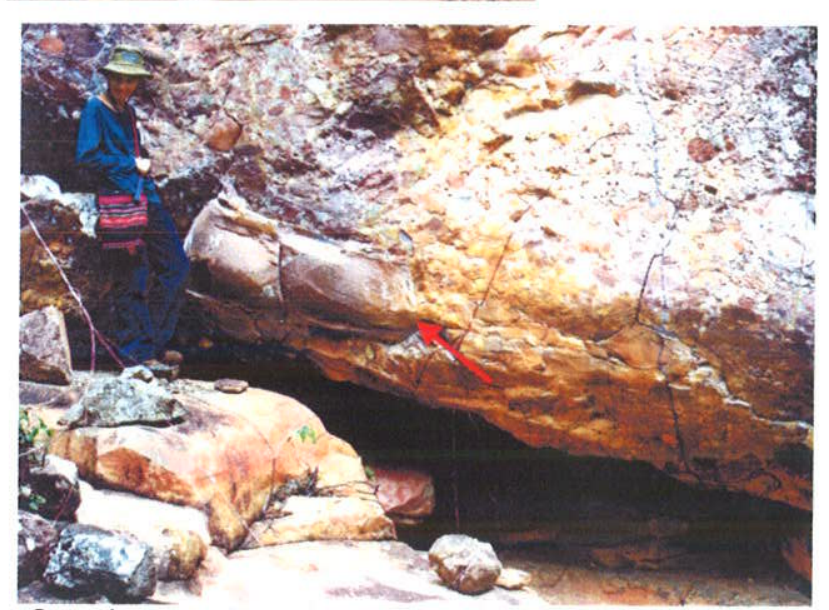

A. Conglomerado sobreposto a arenito eólico. Observar bloco do material eólico sendo erodido e incorporado no conglomerado (seta). 
depósito marinho e sendo recoberto por arenito conglomerático (sexto sistema, a seguir), indica deposição de planície deltaica modificada por marés, dentro de um contexto de fan delta. Paleocorrentes neste sistema mostram grande dispersão, entre $120^{\circ}$ e $310^{\circ}$ (sudeste a noroeste), e ocasionalmente $70^{\circ}$.

Sucedem-se $6,5 \mathrm{~m}$ de arenito conglomerático, com estratificações cruzadas acanalada e tabular, de origem fluvial. Paleocorrentes indicam variação entre $160^{\circ}$ e $300^{\circ}$ (sexto sistema).

O sétimo sistema corresponde a arenitos médios a grossos, com lâminas conglomeráticas e espessas estratificações cruzadas acanalada e tabular, orientadas na média para oeste (variação entre $220^{\circ}$ e $300^{\circ}$, e localmente $30^{\circ}$ ). Observa-se uma sucessão de afinamento ascendente (Fig. VII.3), correspondente possivelmente a um sistema estuarino.

O último sistema, por suas características marinhas, já é ligado geneticamente à Formação Caboclo. Consta de bancos tabulares de arenito fino, com drapes e intercalações sílticas, contendo microestratificação e laminação ondulada truncante, swaley, e localmente delgados estratos cruzados (Fig. VII.3-D).

Em seu conjunto, o perfil do Rio Lençóis é composto por um ciclo de afinamento ascendente, transgressivo (leque aluvial a marinho), seguido de um grande ciclo de engrossamento, regressivo (marinho a fluvial), e finalmente outro ciclo de afinamento, transgressivo (fluvial a marinho = Formação Caboclo) (Fig. VII.3).

\section{PERFIL DO RIO MUCUGEZINHO}

O perfil do último ciclo do intervalo superior, no vale do Mucugezinho, resulta de dois segmentos: o inferior, levantado na margem esquerda do rio, subindo a colina, e o superior, em longo trecho do rio, a partir de intervalo transgressivo marinho que provavelmente se correlaciona com o dos perfis vistos anteriormente. A amarração entre os dois perfis, entretanto, é tentativa, já que o citado intervalo não está claro no perfil da margem esquerda.

O perfil representativo do vale do Mucugezinho é formado de dez sistemas, seqüenciados conforme o quadro abaixo: 


\begin{tabular}{|l|l|l|}
\hline 10 & Arenito e Siltito & Marinho (Formação Caboclo) \\
\hline 9 & Arenito e drapes de Siltito & Flúvio-estuarino \\
\hline 8 & Arenito e lâminas de seixos & Fluvial \\
\hline 7 & Arenito e raro conglomerático & Fluvial e eólico \\
\hline 6 & Arenito fino/médio & Litorâneo e eólico \\
\hline 5 & Arenito grosso & Fluvial torrencial \\
\hline 4 & Arenito e Siltito & Marinho \\
\hline 3 & Arenito e Siltito & Fluvial torrencial \\
\hline 2 & Arenito & Fluvial \\
\hline 1 & Conglomerado e Brecha & Leque aluvial \\
\hline
\end{tabular}

O primeiro sistema, de leque aluvial, com $11 \mathrm{~m}$ de espessura, ocorre na forma canalizada, escavando depósitos eólicos e fluviais (Att e Aa, respectivamente, na Fig. VII.4).

Sucede, no perfil, o segundo sistema: são cerca de $30 \mathrm{~m}$ de depósitos fluviais, na forma de espessos ciclos com base erosiva e clastos argilosos, contendo arenitos grossos com estratificação cruzada acanalada e arenitos médios com laminação horizontal.

O terceiro sistema apresenta cerca de $25 \mathrm{~m}$ de arenito com estratificação cruzada e laminação horizontal, portando lâminas ricas em quartzo leitoso com $1 \mathrm{~cm}$ de diâmetro; tal depósito foi interpretado, em capítulo anterior, como fluvial torrencial (ver Fig. V.5).

Em seguida ocorre, no mesmo perfil, dois delgados intervalos de siltito, totalizando $2 \mathrm{~m}$, que estão sendo correlacionados com os depósitos marinhos da base do perfil levantado no leito do rio (Mu-48); aqui o intervalo alcança $5 \mathrm{~m}$, e apresenta siltito, arenito com microestratificação ondulada truncante capeada por marcas de onda, e estratificação ondulada truncante (hummocky) com gutter cast na base (Fig. VII.4-A).

O quinto sistema, que sucede o intervalo marinho, consiste de quase $30 \mathrm{~m}$ de sedimentos encobertos no leito do rio (entre os pontos Mu-48 e Mu-49), e que tentativamente correlacionamos com a seção de mesma espessura exposta na colina da margem esquerda, sobreposta aos $2 \mathrm{~m}$ de siltito correspondente ao do rio. São arenitos grossos/muito grossos, com lâminas de quartzo leitoso (pebbles de $1 \mathrm{~cm}$ ) e estratos cruzados acanalados, e arenitos médios com laminação horizontal, provavelmente relacionados ao ambiente fluvial torrencial. 
Figura VII.4. Perfil do último ciclo do intervalo superior, Rio Mucugezinho.
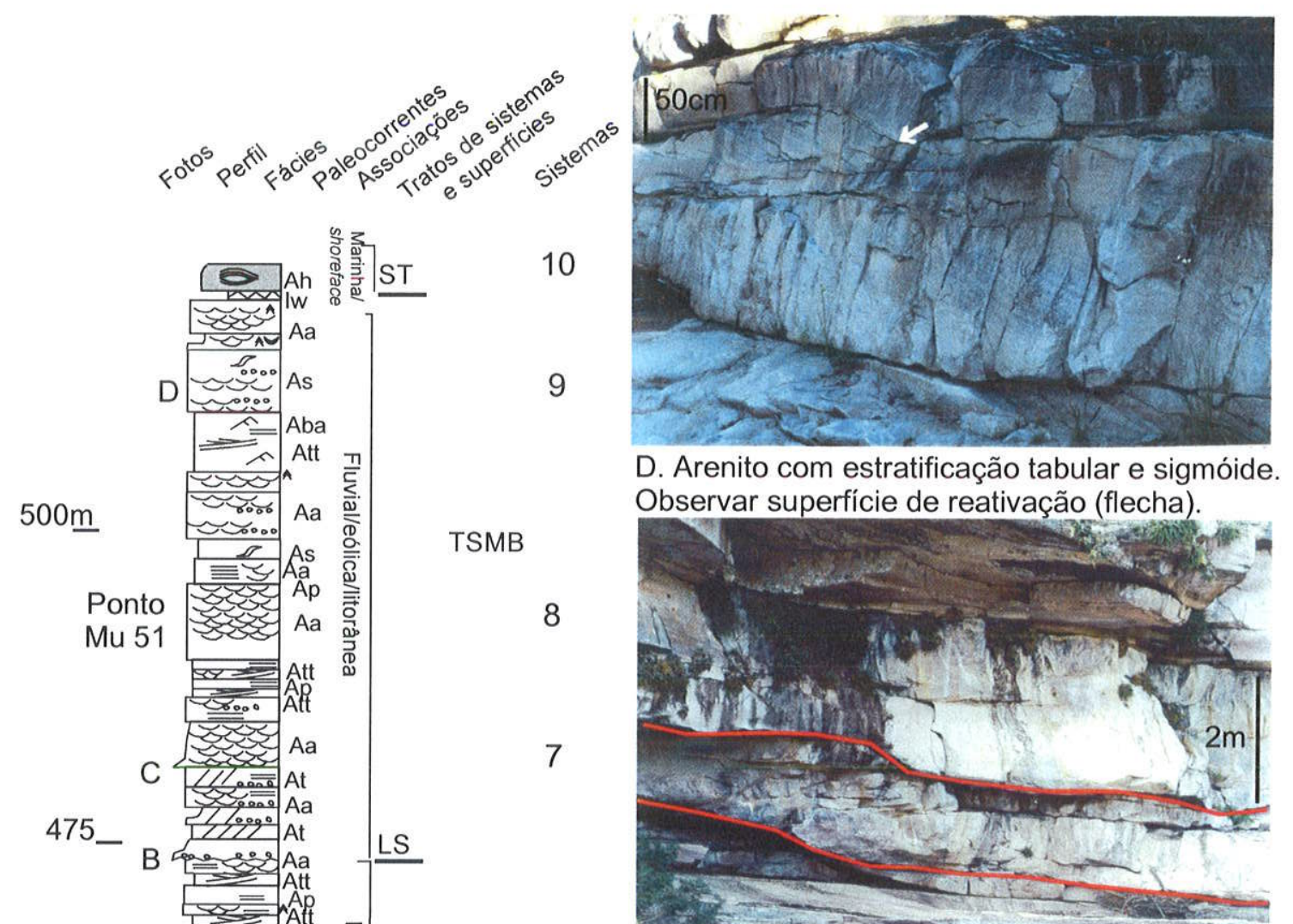

C. Canais de arenito com estratificação cruzada acanalada.
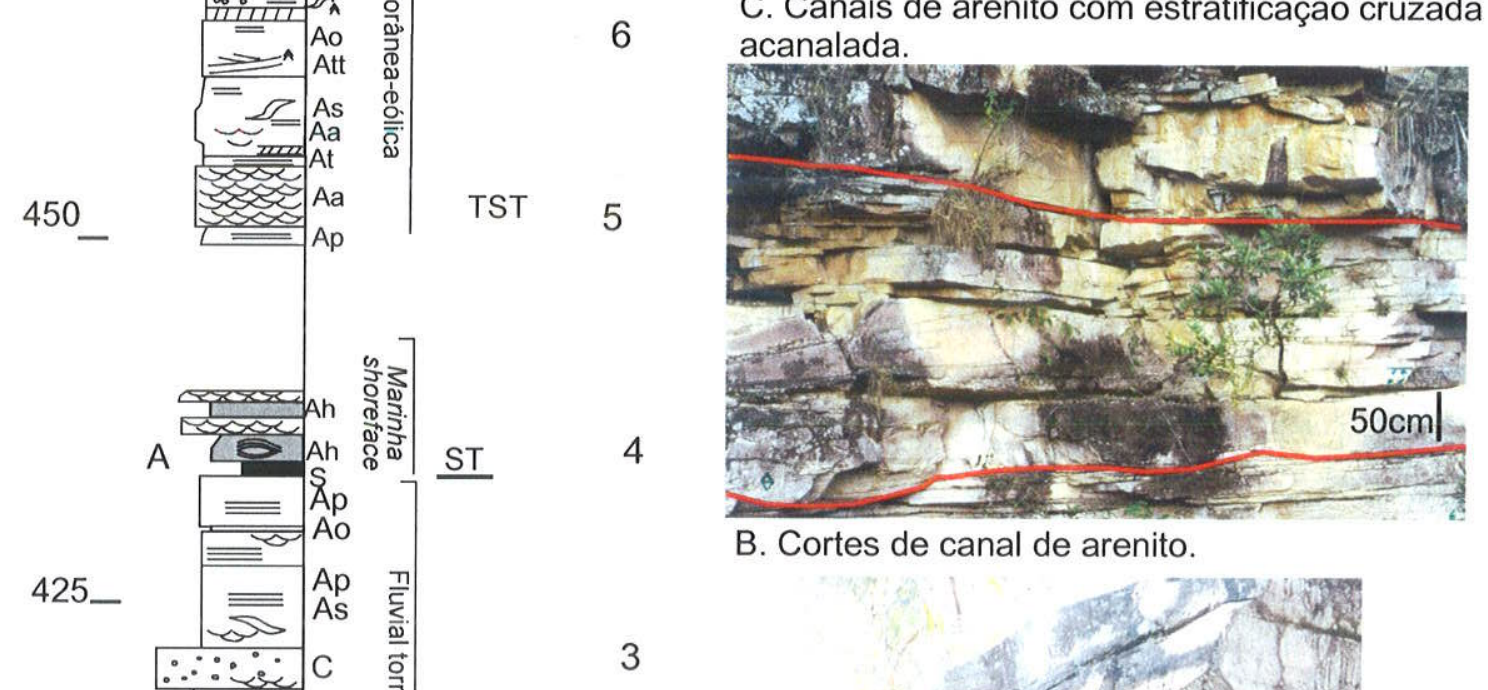

B. Cortes de canal de arenito.

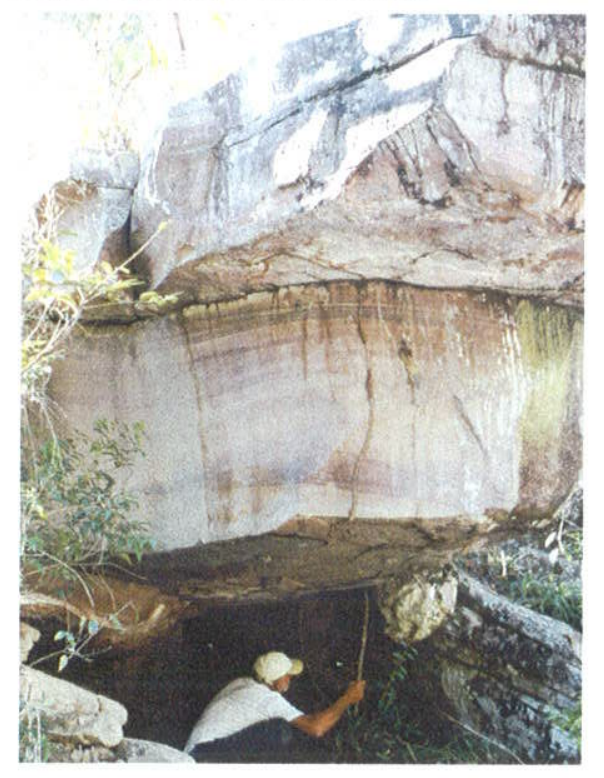

A. Arenito com estratificação ondulada truncante (hummocky). Notar aleitamento gradacional. 
Retornando ao perfil do leito do Rio Mucugezinho (partindo do ponto Mu-49) têm-se, no sexto sistema, quase $18 \mathrm{~m}$ de arenitos médios com laminação horizontal e estratificação cruzada tabular tangencial; niveis de seixos (tamanho $2,5 \mathrm{~cm}$ ) ocorrem nos arenitos laminados, onde raramente se observa também marcas de onda (Fig. VIl.4). Outras estratificações cruzadas, subordinadas, incluem acanalada de pequeno porte, cruzada de baixo ângulo e sigmóide. Os depósitos acima são interpretados como eólicos e litorâneos; paleocorrentes nos arenitos eólicos indicam transporte para leste (entre ENE e ESSE).

O sétimo sistema, com $18 \mathrm{~m}$ de espessura, é formado por dois grandes ciclos de afinamento ascendente, tendo arenitos de canal na base dos ciclos (Figs. VII.4-B, C); os arenitos são grossos e apresentam intercalações (com até $15 \mathrm{~cm}$ de espessura) de conglomerados com seixos que alcançam $6 \mathrm{~cm}$ (quase no limite pebble/cobble). No topo dos ciclos ocorrem arenitos mais finos, com estratificação cruzada tabular-tangencial, de origem eólica. As paleocorrentes fluviais variam entre sul (rara), sudoeste e oeste, enquanto no domínio eólico são para norte, nordeste, leste e sudeste $\left(10^{\circ}\right.$ a $\left.150^{\circ}\right)$.

Representando o oitavo sistema, são cerca de $20 \mathrm{~m}$ de sedimentos na forma de dois ciclos maiores de granodecrescência ascendente (Fig. VII.4). Cada ciclo tem arenitos com estratificação cruzada acanalada na base, seguida de laminação paralela horizontal, estratificação sigmoidal e localmente laminação cruzada clino-ascendente. Também são freqüentes, como em toda a seção, lâminas conglomeráticas com seixos de até $3 \mathrm{~cm}$. O sentido das paleocorrentes fluviais varia entre sul, sudoeste, oeste e noroeste $\left(170^{\circ}\right.$ a $\left.310^{\circ}\right)$, e subordinadamente leste e sudeste $\left(90^{\circ}\right.$ a $\left.150^{\circ}\right)$.

Deve-se destacar, quase no topo do intervalo com estratificação cruzada acanalada, do segundo ciclo, a presença de lâmina argilosa (em parte flaser) indicando alguma influência estuarina. Não é improvável, também, a presença de depósitos eólicos na parte superior do mesmo ciclo.

O penúltimo sistema tem quase $10 \mathrm{~m}$ de espessura, e dois ciclos de granulometria e espessura decrescentes no sentido ascendente (Fig. VIl.4). No primeiro ciclo, arenitos grossos com pavimentos conglomeráticos (clastos de quartzo leitoso de até $2 \mathrm{~cm}$ ) mostram estratificação cruzada acanalada seguida de estratificação cruzada tabular e sigmoidal (Fig. VII.4-D), e retrabalhamento marinho no topo (interlaminação wavy, marcas de ondas, flaser). Já o ciclo superior mostra o retrabalhamento marinho de topo sobre o intervalo de arenito com estratificação cruzada acanalada. As paleocorrentes neste contexto flúvio-estuarino variam entre $170^{\circ}$ e $330^{\circ}$, com maior freqüência para sudoeste e oeste. 
O décimo e último sistema é caracterizado pelos depósitos marinhos já relacionados à Formação Caboclo, em contato abrupto com os depósitos anteriores (Fig. VII.4); ocorre pouco antes da ponte sobre o Rio Mucugezinho, Mu-51).

Em resumo, o perfil do último ciclo do intervalo superior revela aqui uma tendência inicial transgressiva, do leque aluvial ao sistema marinho (primeiro ao quarto sistemas); seguese uma tendência regressiva, que se consuma com o quinto sistema fluvial torrencial, que é transgredido pela sedimentação litorânea-eólica subsequente (sexto sistema); uma nova regressão se processa, entre o sexto e o sétimos sistemas, e finalmente uma marcante tendência transgressiva fluvial-estuarina-marinha do oitavo ao décimo sistemas.

\section{VII.3. CORRELAÇÃO DOS PERFIS DO ÚLTIMO CICLO}

Os quatro perfis elaborados não se distribuem linearmente; três se encontram ao sul, nos rios Capivara, Ribeirão e Lençóis, e o quarto ao norte, Rio Mucugezinho. Apesar de não se conseguir levantar perfis nos rios Lapão e Mandassaia, tenta-se aqui uma correlação entre os perfis do sul com o do norte. Deve-se ter em conta também uma certa complexidade com o vale do Mucugezinho, onde tentou-se levantar perfil na sua margem norte, com dificuldades adicionais.

Há uma boa correlação entre os perfis do Capivara e do Ribeirão, em que pesem as variações faciológicas e ao fato de faltarem, no primeiro perfil (elaborado na margem esquerda do Capivara), depósitos costeiros e eólicos do topo do perfil presentes na margem direita (Figs. VII.5, VII.1). Exceto pelos sistemas de base (leque aluvial) e de topo (marinho, Formação Caboclo), todos os demais mostram mudanças faciológicas, inclusive o terceiro sistema, marinho.

O segundo sistema varia de fluvial (Ribeirão) para leque subaquoso (Capivara). Esta tendência de maior influência marinha está sempre presente no último perfil: por exemplo, enquanto o terceiro sistema é essencialmente marinho no perfil do Rio Capivara, o mesmo torna-se marinho-transicional (frente deltaica?) no Rio Ribeirão. Os sistemas seguintes, de origem flúvio-deltaica no Rio Ribeirão, são dominados por condições deltaicas no Rio Capivara. Finalmente, o último ciclo transgressivo contém depósitos fluviais e subordinadamente eólicos no Ribeirão, e possivelmente fluviais e costeiros-eólicos no Capivara (Fig. VII.5).

A correlação entre os perfis dos rios Ribeirão e Lençóis também é boa, sem grandes variações faciológicas. Entretanto, neste último ocorre uma espessa seção fluvial (terceiro 
Figura VII.5. Seção estratigráfica dos perfis do último ciclo, intervalo superior da Formação Tombador.

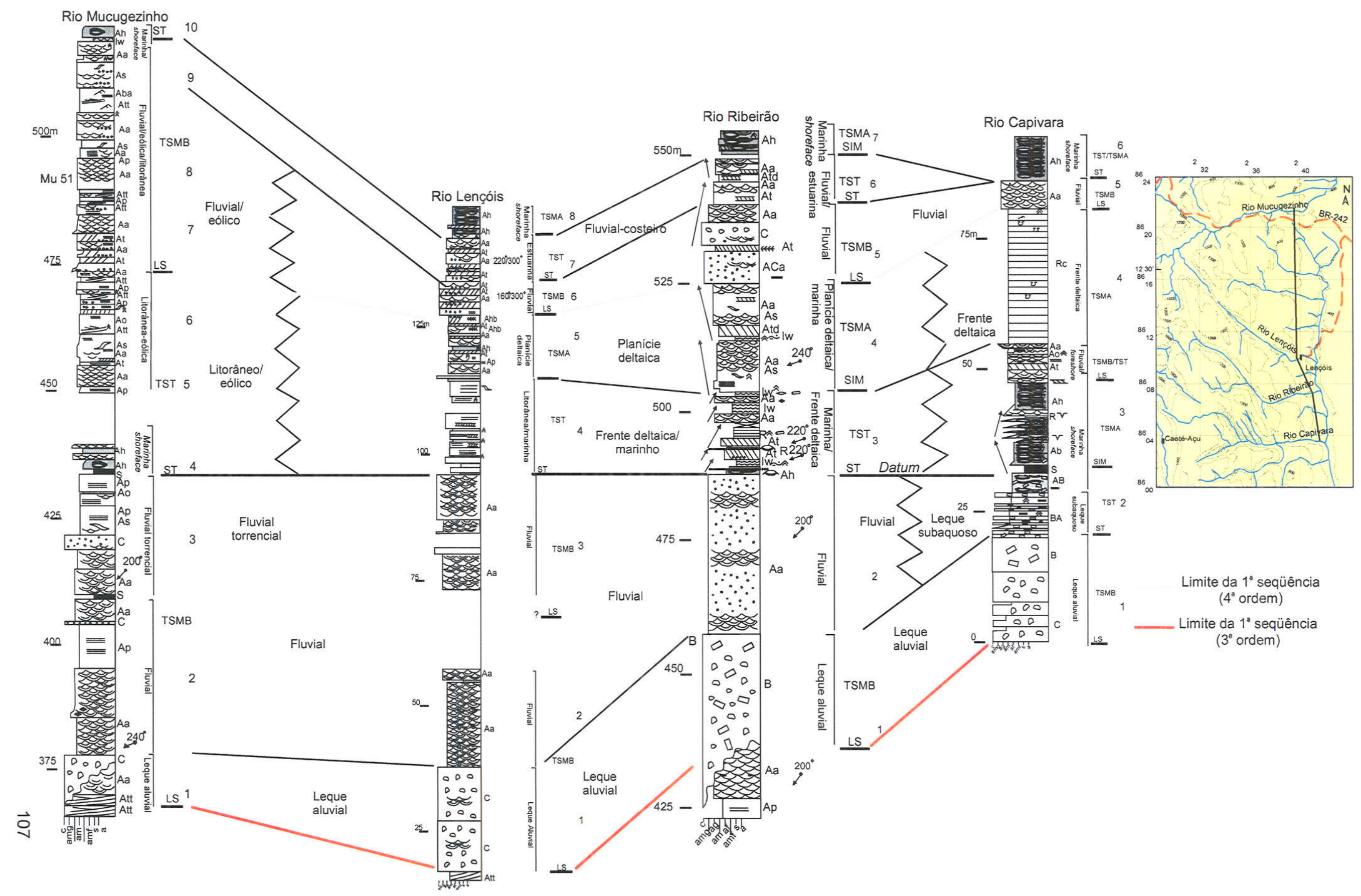


sistema, na "escarpa" da margem esquerda, ver fig. VII.3) que não está presente nos perfis anteriores. O que é mais marcante na correlação é a grande progradação marinha-fluvial entre os terceiro, quarto e quinto sistemas do Ribeirão e os quarto, quinto e sexto sistemas do Lençóis, assim como a transgressão marinha subseqüente (Fig. VII.5).

A correlação entre os perfis dos rios Lençóis e Mucugezinho é marcada por sensiveis variações faciológicas e grandes variações de espessura (Fig. VII.5).

O sistema basal de leque aluvial está bem menos espesso no Mucugezinho, enquanto o sistema fluvial subseqüente, bem característico na área sul, mostra-se mais raso e torrencial no vale do Mucugezinho. Neste, também o sistema marinho mostra-se menos espesso, confirmando a tendência a condições mais marinhas para sul (Capivara).

A partir dai inverte-se a tendência. Tanto o grande ciclo regressivo (quarto ao oitavo sistemas do Mucugezinho), como o transgressivo subseqüente (nono ao décimo sistemas) mostram-se mais espessos no vale do Mucugezinho, quando comparados aos seus equivalentes do Rio Lençóis (respectivamente, quarto ao sexto sistemas, e sétimo ao oitavo sistemas). Nesses sistemas, no perfil do Rio Mucugezinho, ocorre freqüente sedimentação eólica retrabalhando depósitos litorâneos e fluviais; enquanto isso uma sedimentação deltaica, freqüentemente com influência de marés, parece ter dominado o cenário mais ao sul (Fig. VII.5).

Paleocorrentes fluviais, tanto no Mucugezinho como no Lençóis, dirigiram-se preferencialmente para sudoeste e oeste; no Rio Ribeirão também o transporte sul torna-se importante, no sentido do contexto mais distal do vale do Rio Capivara. Em contextos estuarinos ou deltaicos influenciados por marés, comuns na área sul, aquela tendência das paleocorrentes fluviais se mantém, indicando um domínio das condições de marés vazantes. Já as paleocorrentes eólicas do vale do Mucugezinho mostram um sentido contrário, dirigindo-se preferencialmente para leste.

O sistema de leque aluvial observado no início da seção marca a base da última seqüência da Formação Tombador. É sobreposto por uma transgressão caracterizada por sistemas marinhos com retrabalhamento por ondas de tempestade ao sul passando a norte a sistemas litorâneos. O mar se estabiliza com a implantação da plataforma marinha pertencente à Formação Caboclo sobrejacente. Superimposta a essa seqüência de $3^{\text {a }}$ ordem identificou-se uma seqüência de $4^{\mathrm{a}}$ ordem na base de arenitos fluviais, flúvio-costeiros no topo da seção (Fig. VII.5). 


\section{CAPÍTULO VIII}

\section{DISCUSSÕES}

No presente trabalho foram descritas na Formação Tombador, na região de Lençóis, 20 fácies sedimentares agrupadas em 16 associações faciológicas correspondentes aos sistemas deposicionais: leque aluvial, fan delta, leque subaquoso, fluvial torrencial, fluvial, eólico, estuarino, deltaico, litorâneo, marinho (barra de marés) e marinho shoreface. Foi possível dividir a referida formação, com quase $600 \mathrm{~m}$ de espessura, em dois intervalos, inferior e superior. $O$ intervalo inferior evolui segundo três ciclos, com sistema fluvial passando a transicional (estuarino e deltaico), depois eólico a novamente transicional litorâneo, e finalmente fluvial a eólico para o topo. No início do intervalo superior se desenvolveu um sistema francamente continental, de leque aluvial; com exceção desse período, a proximidade com a costa está bem evidente em todo o registro. Neste intervalo foram identificados pelo menos quatro episódios de soerguimento manifestados na área. Esses episódios de soerguimento foram responsáveis pela formação de sistemas de leque aluvial, com canibalização da própria bacia. Os sistemas de leque são sucedidos por sistemas fluvial e é́lico. No último ciclo do intervalo superior, mais complexo, os leques passam para sistemas fluvial seguidos de sistemas marinho a sul e predominantemente transicional ao norte. De acordo com os dados das paleocorrentes, a provável área fonte dos sedimentos estaria a leste. Quanto à transgressão do "Mar Caboclo", conforme medidas das cristas das marcas de onda é possível dizer que a direção da linha de costa estaria orientada entre leste-oeste e sudestenoroeste. Além disso, com o vento soprando para norte/nordeste, possivelmente o mar teria vindo de sul/sudoeste.

Bonfim et al. (1996) mapearam cinco unidades litocronoestratigráficas ( 3 a 7) na Formação Tombador e uma unidade (8) na Formação Caboclo, na área do Parque Nacional da Chapada Diamantina. Segundo os autores, o ambiente evoluiu sucessivamente de fluvial entrelaçado/eólico (unidade 3) para eólico (4), fluvial entrelaçado (5), e leque aluvial/fluvial entrelaçado $(6,7)$, na Formação Tombador, e para planicie de marés (8), com a transgressão do "Mar Caboclo".

Pedreira (1997) individualizou doze diferentes litofácies para os sedimentos do Supergrupo Espinhaço que afloram na Chapada Diamantina centro-oriental. Considerou-se cada litofácies como produto de um evento deposicional individual e as associações de litofácies como produto de ambientes deposicionais específicos. Para a Formação Tombador foram identificadas as litofácies de conglomerado, de arenito, e de granulação fina. Essas 
litofácies se combinam em diversas associações que compõe os sistemas de leque aluvial e desértico. A sedimentação inicialmente é continental, representada por sistemas desértico e de leque aluvial e fluvial, com área fonte a oeste, que transicionam para um sistema deltaico. Sobre o sistema deltaico anterior, após um evento tectônico que basculou a bacia invertendo a direção das paleocorrentes, ocorrem novamente sistemas continental e marinho.

Sob o ponto de vista da estratigrafia seqüencial, no presente trabalho, a partir da realização de um estudo mais detalhado na Formação Tombador, foi possível reconhecer cinco seqüências deposicionais no intervalo inferior da Formação Tombador e outras quatro no intervalo superior, possivelmente de $3^{\text {a }}$ ordem. Muito provavelmente toda a sucessão Tombador-Caboclo corresponderia a uma seqüência de $2^{\text {a }}$ ordem.

Dominguez \& Rocha (1991), Dominguez (1993) e Pedreira (1994) individualizaram as formações Tombador e Caboclo como uma única seqüência deposicional. Dominguez (1992) atribui uma $2^{a}$ ordem ou até mesmo uma $1^{\underline{a}}$ ordem para a sucessão Tombador-Caboclo como um todo, para a região da Chapada Diamantina. Por se tratar de trabalhos de cunho regional, os autores não foram observaram seqüências menores.

Devido às diferenças tectônicas e paleoambientais, é possível que o intervalo de tempo das seqüências de $3^{\text {a }}$ ordem no Fanerozóico, de 0,5 a 3 milhões de anos (Vail 1987), não corresponda ao mesmo intervalo das seqüências de $3^{\text {a }}$ ordem do Proterozóico. Conforme mencionado no capítulo IV, com a ausência de dados bioestratigráficos e de uma datação mais precisa no intervalo analisado, torna-se muito difícil inferir as ordens e duração das seqüências.

Alguns limites de seqüências de $3^{\text {a }}$ ordem identificados no intervalo superior foram formados em resposta a soerguimentos tectônicos, e portanto correspondem a tectonosseqüências. É importante lembrar que quando se trabalha em direção ao continente, a tectônica exerce um papel maior que aquele desempenhado pelo nivel de base marinho. De qualquer modo, o paradigma da Estratigrafia de Seqüências reconhece que o preenchimento sedimentar de uma bacia é controlado pelas variações relativas do nível do mar, resultantes da interação da eustasia e da tectônica.

No perfil do Morro do Pai Inácio, para a seqüência inicial do intervalo inferior, também foram reconhecidas quatro seqüências de alta freqüência (4 $4^{a}$ ordem) superimpostas à de $3^{\text {a }}$ ordem. Tais seqüências de $4^{\text {a }}$ ordem refletem um controle autogênico, enquanto as de $3^{\text {a }}$ ordem um controle alogênico. As seqüências de $4^{a}$ ordem foram reconhecidas também por $G$. Raja Gabaglia (informação verbal) em treinamento de campo da Petrobrás na área de estudo. 
Alguns problemas enfrentados no decorrer do trabalho merecem ser comentados. Primeiro o fato de que a Formação Tombador ainda não está devidamente datada. A unidade sotoposta, Grupo Rio dos Remédios, fol datada no Paleoproterozóico, enquanto a unidade sobreposta, Grupo Una, no Neoproterozóico. Como o Grupo Chapada Diamantina encontra-se entre essas unidades, foi atribuida a idade Mesoproterozóico. No trabalho de Macedo \& Bonhomme (1984) foram feitas análises em amostras de um nível de argilito e siltito da região de Morro do Chapéu pertencente à Formação Caboclo, datando-a em $960 \mathrm{Ma}$. Segundo esses autores, devido ao número reduzido de amostras no trabalho a datação não é de toda conclusiva. Brito Neves et al. (1979) e Rocha et al. (1990) e Dominguez (1993) estabeleceram a idade de deposição da Formação Caboclo em torno de 1,3 Ga. De um modo geral não há informação precisa quanto ao tempo de deposição da Formação Tombador, tornando-se mais dificil a aplicação da Estratigrafia de Seqüências. As ordens das seqüências encontradas na Formação Tombador foram apenas inferidas, devido a falta de dados de datação. Apesar da excelente preservação dos depósitos, a interpretação quanto aos paleoambientes foi muitas vezes difícil principalmente no intervalo inferior, devido a sedimentação monótona sem mudanças significativas de fácies e do padrão de empilhamento sedimentar, e ao forte efeito diagenético da cimentação impresso nos quartzitos. 


\section{CAPÍTULO IX \\ CONCLUSÕES}

A presente tese abordou a Formação Tombador, terço inferior do Grupo Chapada Diamantina, na região de Lençóis, porção oriental da Serra do Sincorá. A Serra do Sincorá ou Anticlinal do Sincorá é formada predominantemente por arenitos da Formação Tombador. Na área de estudo a seqüência Tombador-Caboclo repousa discordantemente sobre a Formação Guiné, Grupo Paraguaçu. Os flancos do anticlinal são constituídos de arenitos pertencentes à Formação Tombador. O eixo do anticlinal foi erodido expondo a Formação Guiné.

Foram descritas 20 fácies sedimentares agrupadas em 16 associações faciológicas.

A associação de leque aluvial é constituida por conglomerados relacionados a rios entrelaçados cascalhentos, com fluxo para oeste/noroeste, formados em sistemas de leque aluvial, e brechas provavelmente está relacionada à parte proximal de leques, associada a um relevo mais íngreme e com pouco transporte e retrabalhamento por água.

A associação de leque subaquoso é constituída por estratos métricos com base erosiva, de brecha gradando a arenito, este com laminações horizontal ou ondulada. A presença de clastos arredondados e de feições de imbricação sugere a ação de correntes trativas unidirecionais, enquanto os arenitos com laminação ondulada sugerem uma origem marinha rasa.

A associação fan delta estuarina compreende duas sucessões faciológicas. A primeira é formada por um conjunto granodecrescente ascendente de conglomerado intercalado com siltito arenito com drapes de siltito, e siltitos. O conjunto retrogradante acima indica uma evolução geral transgressiva a partir de um leque aluvial inicial. A segunda apresenta uma organização granocrescente ascendente de siltitos e arenitos finos intercalados com um corpo tabular de conglomerado. Seguem-se estratos de arenito com estratificação cruzada acanalada separados entre si por drapes de siltito sobrepostos por arenitos com estratificação cruzada acanalada e níveis de seixo.

A associação fluvial torrencial compreende arenitos médios a muito grossos com estratificações cruzada acanalada e horizontal e lâminas conglomeráticas, ritmito arenito/siltito, siltito e arenito fino com laminação cruzada por ondas. Os arenitos com estratificações cruzada acanalada e horizontal constituem depósitos fluviais torrenciais, que se formam a partir de correntes tracionais rasas de regime de fluxo superior com sentido preferencial para sul. A intercalação dessas fácies com sedimentos finos marinhos evidenciam fases transgressivas de afogamento marinho. 
A associação fluvial compreende arenitos conglomeráticos com estratificação cruzada acanalada, arenitos médios a grossos com estratificações cruzadas acanalada e tabular, e ocasionalmente arenito fino com laminação cruzada clino-ascendente. Estão associadas a canais arenosos entrelaçados, com paleocorrentes predominantemente no sentido sudoeste e oeste.

A associação fluvial costeira é amplamente dominada por arenitos finos a médios com estratificação cruzada acanalada ou laminações horizontal e cruzada, modificadas por ondas e lentes de flaser

A associação eólica engloba as fácies arenito médio com estratificação cruzada tabular tangencial e arenito médio com laminação horizontal. Estão relacionados a depósitos de dunas e prováveis de lençóis de areia (sandsheet).

A associação litorânea compreende predominantemente arenitos com laminação horizontal e cruzada por onda, e arenito com estratificação cruzada de baixo ângulo. Os arenitos com estratificação cruzada de baixo ângulo e horizontal compõe a estratificação tipo swash da praia.

A associação deltaica é formada por arenitos, dispostos em camadas horizontais (topsets) sobrepostos a siltito marinho, que gradam a camadas inclinadas frontais (foresets) recobertos por depósitos fluviais. Esse arranjo progradante de camadas de topo e frontais pode ser atribuída a um delta tipo Gilbert, associado a águas rasas com avanço para leste.

A associação frente deltaica foi observada compreende ritmitos areno-silticos com laminação cruzada por correntes ou por ondas, e quando deformados contém estruturas de carga e pilares arenosos. A referida associação se formou em um contexto de frente deltaica, provavelmente como deltas de crevasse. A deformação pode ter sido provocada por choques sísmicos.

A associação planície deltaica é representada por progradação de arenito com estratificação cruzada acanalada e sigmóide, em sets unidirecionais com 0,5 a $1,0 \mathrm{~m}$ de espessura e paleocorrentes para WSW.

A associação marinha/frente deltaica é composta por duas fácies, sendo uma de arenitos com estratificação cruzada tabular e acanalada (frente deltaica), recobrindo a outra de arenitos e siltitos (tempestitos de ambiente marinho shoreface).

A associação estuarina marinha compreende com arenitos de canal passando a arenitos e siltitos marinhos. A fácies de arenito de canal apresenta estratificação cruzada acanalada e sigmóide, com superfícies retrabalhadas por ondas, estratificação espinha-depeixe e drapes/megaflasers sílticos entre os estratos arenosos. A fácies de arenitos exibem estratificação ondulada truncante (hummocky, microhummocky) e gradam a siltitos. Essa organização granodecrescente das duas fácies sugere um contexto transgressivo, com 
depósitos tracionais de preenchimento de canal (com feições de maré) gradando a tempestitos marinhos.

A associação estuarina distal/marinha consiste de arenitos intercalados com siltitos/ritmitos finos, com geometria tabular. O arenito mostra estratificação cruzada acanalada e sigmoidal às vezes modificadas por ondas. O siltito ou ritmito fino mostra lentes e delgados estratos arenosos com laminação cruzada clino-ascendente ou cruzada por ondas, sugerindo às vezes tempestitos delgados.

A associação marinha (barras de marés) consiste de arenitos tabulares/amalgamados, arenitos tabulares bifurcando-se em arenitos e siltitos delgados/lenticulares, estratos de arenito gradando a siltito, e ritmitos areno-argilosos e siltitos. Tais fácies sucedem-se verticalmente segundo padrões granodecrescente ascendente, formado por arenito amalgamado e arenito gradando a siltito, e granocrescente ascendente, com siltito e ritmito sucedidos por arenito com estratos bifurcantes, neste caso representando o modelo de barra de marés (Mutti et al. 1988).

A associação marinha shoreface é representada por siltito, arenito com estratificação ondulada truncante hummocky e microhummocky, ritmito arenito/siltito, interlaminado e arenito/siltito (wavy) com laminação cruzada por onda (tempestitos). Localmente encontram-se de brechas associadas aos tempestitos formadas possivelmente por choques sísmicos. Em alguns locais também são vistos tempestitos deformados, com dobras convolutas, pseudonódulos e diques de arenito.

De um modo geral, a Formação Tombador com mais de $600 \mathrm{~m}$, foi dividida em intervalo inferior e superior, ou intervalo pré-conglomerado e pós-conglomerado.

O intervalo inferior com cerca de $250 \mathrm{~m}$ de espessura consiste predominantemente das associações fluvial, estuarina, deltaica, marinha, litorânea e eólica. Esse intervalo apresenta uma sedimentação extremamente monótona formada provavelmente numa época de mar alto e/ou grande subsidência na bacia possibilitando a preservação de um pacote com expressiva espessura.

O contato entre as formações Guiné e Tombador foi descrito apenas no Morro do Pai Inácio junto a BR-242. A Formação Guiné é constituída por sedimentos deltaicos sobrepostos por sedimentos fluviais da Formação Tombador, caracterizando um limite de seqüencias entre essas unidades.

O intervalo superior consiste de mais de $300 \mathrm{~m}$ de espessura. Apresenta as associações de leque aluvial, fluvial, fluvial torrencial, eólica, deltaica, estuarina, fan delta estuarina, litorânea e marinha. Há pelo menos quatro níveis de conglomerados bem exemplificados no perfil do Rio Mucugezinho. A presença dos leques aluviais é resposta aos sucessivos episódios de soerguimento, além de canibalização da bacia durante a sedimentação. 
Os depósitos fluviais apresentam paleocorrentes com sentido para oeste/noroeste. Ao contrário das paleocorrentes medidas nos depósitos eólicos com sentido do vento para norte/nordeste. Medidas nas cristas das marcas de ondas dos sedimentos marinhos depositados ao final da Formação Tombador e início da Formação Caboclo indicam um linha de costa com direção noroeste/sudeste. De acordo com essas medidas e com o sentido dos ventos pode-se inferir que a transgressão do "Mar Caboclo" possivelmente veio de sul/sudoeste.

$\mathrm{Na}$ passagem para a Formação Caboclo, novamente há indícios de tectonismo sinsedimentar registrados em sedimentos costeiros (foreshore) e marinhos (shoreface) com estruturas de deformação geradas quando os sedimentos encontravam-se inconsolidados/semi-consolidados. O mecanismo de disparo responsável pela deformação dos sedimentos pode ter sido sismos.

$O$ intervalo inferior apresenta cinco seqüencias, possivelmente de $3^{\text {a }}$ ordem. As seqüências são normalmente constituídas na base por um trato sistemas de mar baixo, com depósitos fluvial, fluvial costeiro e eólico, sucedido por um trato de sistemas transgressivo englobando depósitos estuarino, estuarino/marinho e litorâneo.

No intervalo superior foram identificadas quatro seqüências de $3^{\text {a }}$ ordem e uma possivelmente de $4^{\mathrm{a}}$ ordem. As seqüências de $3^{\mathrm{a}}$ ordem formadas principalmente devido ao soerguimento tectônico foram chamadas de tectonosseqüência. Infelizmente devido ao desconhecimento quanto ao tempo de deposição dos sedimentos da Formação Tombador, a interpretação quanto à ordem foi inferida através das espessuras das seqüências, mudanças abruptas de fácies e sistemas deposicionais. Com certeza as tectonosseqüências representam uma ordem menor, refletindo possivelmente controle alocíclico, enquanto a de $4^{\mathrm{a}}$ ordem, um controle autocíclico.

De um modo geral, a Formação Tombador pode ser dividida em duas fases: préconglomerados e pós-conglomerados. A fase pré-conglomerados (intervalo inferior da formação) é marcada por quiescência sedimentar na bacia, onde houve a deposição de sistemas deltaico, estuarino, fluvial, litorâneo e eólico. A fase pós-conglomerado (intervalo superior) é caracterizada por intenso tectonismo, inclusive com canibalização da própria bacia. A sedimentação é representada por depósitos de leques aluviais intercalados com fluviais e eólicos, cedendo lugar gradativamente a sistemas costeiros e marinhos shoreface, com retrabalhamento por ondas de tempestade, correspondentes à Formação Caboclo. 
O último ciclo do intervalo superior apresenta a última seqüência deposicional de $3^{\text {a }}$ ordem na Formação Tombador e uma seqüência de $4^{a}$ ordem superimposta. A seção estratigráfica elaborada para esse ciclo inicia-se com sistemas de leque aluvial passando a fluvial para o topo e leque subaquoso (Rio Capivara). A base do sistema de leque é marcada por uma discordância, caracterizando um limite de seqüências. A seguir uma transgressão marinha é responsável pela formação de sistemas litorâneos a norte gradando a deltaicos e marinhos para o sul, inseridos num trato de sistemas transgressivo. O trato de mar alto é caracterizado por sistemas litorâneo-eólico ao norte com progradação deltaica para sul, finalizando a primeira seqüência.

A seqüência de $4^{a}$ ordem superimposta inicia-se com sistemas fluvial-eólico a norte passando a fluvial para o sul, num trato de sistemas de mar baixo. O ciclo transgressivo seguinte apresenta sistemas fluvial-costeiro e estuarino (trato de sistemas transgressivo) sucedidos por sistema marinho shoreface, correspondente à transgressão do "Mar Caboclo"

O Grupo Chapada Diamantina, de acordo com o trabalho de White (1980), representa um grande ciclo transgressivo-regressivo de $2^{\text {a }}$ ordem (facies cycle wedge), onde o componente transgressivo é constituído pelas formações Tombador e Caboclo, e o regressivo corresponde à formação Morro do Chapéu. 


\section{REFERÊNCIAS}

ALMEIDA, F.F.M. 1977. O Cráton do São Francisco. Revista Brasileira de Geociências, 7: 349364.

BONFIM, L.F.C., KRUG, L. \& NOLASCO, M.C. 1996. Roteiro de Excursão Geológica Chapada Diamantina Central - Geologia e Recursos Minerais. In: Congresso Brasileiro de Geologia, SBG, Salvador, $15 \mathrm{p}$.

BRANNER, J.C. 1910a. The Tombador Escarpment in the State of Bahia. American Journal of Science, 30: 335-343.

BRITO NEVES, B. B. 1967. Geologia das Folhas de Upamirim e Morro do Chapéu-BA. Recife: CONESP (CONESP. Relatório, 17), $53 \mathrm{p}$.

BRITO NEVES, B. B., KAWASHITA, K. CORDANI, U. \& DELHAL, J. 1979. A evolução geocronológica da Cordilheira do Espinhaço: dados novos e integração. Revista Brasileira de Geociências, 9: 71-85.

BRITO NEVES, B. B. \& LEAL, A.S. 1968. Elementos de Estratigrafia do Médio São Francisco. In: IV Simpósio de Geologia do Nordeste, Recife. Atas... Recife: SBG, 4.

BROWN, L.F. \& FISHER, W.L. 1977. Seismic-stratigraphic interpretation of depositional systems: examples from Brazil rift and pull-apart basins. In: C.E., Payton (ed.), Seismic Stratigraphy - Applications to Hydrocarbon Exploration: American Association of Petroleum Geologists Memoir 26, 213-248.

CASTRO, M.R. 2002. Deformação sin-deposicional em Depósitos Costeiros e Marinhos das Formações Tombador e Caboclo, Grupo Chapada Diamantina, BA. Revista Brasileira de Geociências, 32 (2): 147-150. 
CASTRO, P.T.A. 1993. O Emprego de Estratigrafia de Seqüências em Terrenos Mesoproterozóicos do Estado da Bahia - Uma Discussão. Revista Brasileira de Geociências, 23: 330-332.

CASTRO J.C., ROHN R., CASTRO, M.R. \& TOLEDO C. 2001. Camadas de Tempestito Grosso (Coarse Grained Storm Beds): Exemplos do Permiano da Bacia do Paraná. Revista da Escola de Minas, 54 (3): 179-184.

CASTRO, M.R., RICCOMINI, C., CASTRO, J.C. \& KRUG, L.. 2001. Arquitetura estratigráfica de uma tectonosseqüência na parte superior da Formação Tombador, Chapada Diamantina, BA. VI Simpósio Nacional de Estudos Tectônicos. Recife-PE, p. 139.

CATUNEANU, O. \& ERIKSSON, P.G. 1999. The Sequence Stratigraphic Concept and the Precambrian Rock Record: an Example from 2.7-2.1 Ga Transvaal Supergroup, Kaapvaal Craton. Precambrian Research, 97/3 (4): 215-252.

CHRISTIE BLICK, N., DYSON, I., VON DER BORCH, C.C. 1995. Sequence Stratigraphy and Interpretation of Neoproterozoic Earth History. Precambrian Research, 73: 3-26.

COLLINSON, J.D. 1996. Alluvial Sediments. In H.G. Reading, org.: Sedimentary Environments: process, facies and stratigraphy. Oxford, Blackwell Science, p. 37-82.

DALRYMPLE, R.W., ZAITLIN, B.A. \& BOYD, R. 1992. Estuarine facies models: conceptual basis and stratigraphic implications. Journal of Sedimentary Petrology, 62 (6):1030-1046.

DANDERFER FILHO, A. 1990. Análise Estrutural Descritiva e Cinemática do Supergrupo Espinhaço na região da Chapada Diamantina, BA. Dissertação de Mestrado. Instituto de Geociências, Universidade Federal de Ouro Preto, Ouro Preto, $119 \mathrm{p}$.

DANDERFER FILHO, A., LAGOEIRO, L.E. \& ALKMIM, F.F. 1993. O sistema de dobramentos e empurrões da Chapada Diamantina (BA): registro da inversão do aulacógeno do Espinhaço no decorrer do Evento Brasiliano. In: II Simpósio do Cráton do São Francisco, Salvador Anais, 197-199.

DELLA FÁVERA, J.C. 2001. Fundamentos de Estratigrafia Moderna. Rio de Janeiro, EdUERJ, $263 \mathrm{p}$. 
DOMINGUEZ, J.M.L. 1996. As coberturas plataformais do Proterozóico Médio e Superior. In: J.S.F., Barbosa \& J.M.L., DOMINGUEZ (eds.), Geologia da Bahia - texto explicativo. Secretaria da Industria, Comércio e Mineração do Estado da Bahia Superintendência de Geologia e Recursos Minerais, Salvador, 105-125.

DOMINGUEZ, J.M.L. 1993. As coberturas do Cráton do São Francisco: uma abordagem do ponto de vista de análise de bacia. In: J.M., DOMINGUEZ \& A., MISI (eds.) O Cráton do São Francisco. Salvador, SBG/SGM/CNPq, 137-159.

DOMINGUEZ, J.M.L. 1992. Estratigrafia de Seqüências aplicada a Terrenos Pré-cambrianos: exemplos para o Estado da Bahia. Revista Brasileira de Geociências, 22: 422-436.

DOMINGUEZ, J.M.L. \& ROCHA, A.J.D. 1991. Roteiro de Excursão Geológica, Grupos Chapada Diamantina e Una. In: Proterozóico Médio e Superior no Brasil, Conferência de Campo, Morro do Chapéu, Salvador: CPRM/SBG/UFBa, 27 p.

ERIKSSON, P.G., CONDIE, K.C., TIRSGAARD, H., MUELLER, W.U., ALTERMANN, W., MIALL, A.D., ASPLER, L.B., CATUNEANU, O., CHIARENZELLI, J.R. 1998. Precambrian Clastic Sedimentation Systems. Sedimentary Geology, 120: 5 -53.

EYLES, N. 1993. Earth's glacial record and its tectonic setting. Earth-Science Review, 35: 1248.

GALLOWAY, W.E. 1989. Genetic stratigraphy sequence in basin analysis: architecture and genesis of flooding surface bounded depositional units. American Association of Petroleum Geologists Bulletin, 73: 125-142.

GALLOWAY, W.E. 1975. Process framework for describing the morphologic and stratigraphic evolution of deltaic depositional systems. In: Broussard, M.L. (ed.), Deltas Models for Exploration. Houston Geological Society, 87-98.

JARDIM DE SÁ, E.F., BARTELS, R.L., BRITO NEVES, B.B. \& MCREATH, I. 1976. Geocronologia e modelo tectonomagmático da Chapada Diamantina e Espinhaço Setentrional. 29- Congresso Brasileiro de Geologia, Ouro Preto-MG. Anais, 4: 205-227. 
KOCUREK G.A.. 1996. Desert aeolian systems. In H.G. Reading, org.: Sedimentary Environments: process, facies and stratigraphy. Oxford, Blackwell Science, p. 125-153.

LINDSAY, J.F. 1987. Sequence Stratigraphy and Depositional Controls in Late ProterozoicEarly Cambrian Sediments of Amadeus Basin, Central Australia. The American Association of Petroleum Geologists Bulletin, 71 (11): 1387-1403.

MACEDO, M.H.F. \& BONHOMME, M.G. 1984. Contribuição à Cronoestratigrafia das Formações Caboclo, Bebedouro e Salitre na Chapada Diamantina (BA) pelos métodos de Rb-Sr e K-Ar. Revista Brasileira de Geociências, 14 (3): 153-163.

MISI, A. \& SILVA, M.G. 1996. Chapada Diamantina Oriental - Bahia: Geologia e depósitos minerais. Superintendência de Geologia e Recursos Minerais - SGM, Salvador, 194 p.

MEDEIROS, R.A. \& PEREIRA, C.P. 1994. Chapada Diamantina (São Francisco Basin). In: $14^{\text {th }}$ International Sedimentological Congress, Recife, Field Trip Guide Book, 5 p.

MITCHUM, R.M. 1977. Seismic Stratigraphy and Global Changes of Sea Level, Part 1: Glossary of terms used in seismic stratigraphy, In: C.E., Payton (ed.) Seismic Stratigraphy - Applications to Hydrocarbon Exploration: American Association of Petroleum Geologists Memoir 26, p. 205-212.

MUTTI, E., ROSELL, J., ALLEN, G.P., FONNESU, F. \& SGAVETTI, M. 1988. The Eocene Baronia Tide Dominated Delta-Shelf System in the Arger Basin. In: American Association of Petroleum Geologists Congress. Excursion n. 13 Guide Book, 22 p.

OLIVEIRA, J.E. \& LEONARDOS, O.H. 1940. Geologia do Brasil. Rio de Janeiro: Comissão Brasileira do Centenário de Portugal, $472 p$.

PEDREIRA, A.J. 1997. Sistemas Deposicionais da Chapada Diamantina Centro-oriental, Bahia. Revista Brasileira de Geociências, 27: 229-240.

PEDREIRA, A.J. 1994. O Supergrupo Espinhaço na Chapada Diamantina Centro-oriental, Bahia: sedimentologia, estratigrafia e tectônica. Universidade de São Paulo, São Paulo, Tese de Doutoramento, $125 \mathrm{p}$. 
PEDREIRA., A.J. 1988. Seqüências Deposicionais do Pré-Cambriano: exemplo da Chapada Diamantina Oriental, Bahia. In: SBG, XXXV Congresso Brasileiro de Geologia, SBG, Belém, 2: 648-659.

POSAMENTIER, H.W. \& JAMES, D.P. 1993. An overview of sequence stratigraphy concepts: uses and abuses. In: H.W., Posamentier, C.P., Summerhayes, B.U., Haq, \& G.P., Allen (eds.) Sequence Stratigraphy and Facies Associations. Oxford, Special publications, Blackwell Scientific Publications. International Association of Sedimentologists, 18: 3-17.

POSAMENTIER, H.W., \& VAIL, P.R. 1988. Eustatic controls on clastic deposition I- sequence and systems tract models, In: C.K., Wilgus, B.S., Hastings, C.G.St.C., Kendall, H.W., Posamentier, C.A., Ross \& J.C., Van Wagoner (eds.), Sea Level Changes: an integrated approach: SEPM Special Publication Sociey of Economic Paleontologists and Mineralogists, 42: 109-124.

ROCHA, A.J. 1992. Evolução Paleogeográfica do Grupo Chapada Diamantina na região de Morro do Chapéu (BA). In: Congresso Brasileiro de Geologia, SBG, São Paulo. Bol. Res. Exp. São Paulo, 2: 447-448.

ROCHA, A.J.D., PEDREIRA, A.J. \& PEREIRA, C.P. 1996. Roteiro de Excursão Geológica Chapada Diamantina Central - Geologia e Recursos Minerais. In: Congresso Brasileiro de Geologia, SBG, Salvador, $43 p$.

ROCHA, A.J.D., PEREIRA, C.P. \& SRIVASTAVA, N.K. 1990. Seqüências carbonáticas da Formação Caboclo na Folha Morro do Chapéu (Bahia). In: Congresso Brasileiro de Geologia, SBG, Natal, 1: 49-65.

ROSSETTI, D.F. \& GÓES, A.M. 2000. Deciphering the sedimentological imprint of paleoseismic events: an example from Aptian Codó Formation, northern Brazil. Sedimentary Geology, 135: $137-156$.

SAVINI, R.R. \& RAJA GABAGLIA, G.P. 1997. Curso de Campo da Chapada Diamantina - Guia de Campo. Lençóis (BA): Petrobrás, 15 p.

SHANLEY, K.W. \& McCABE, P.J. 1994. Perspectives on the Sequence Stratigraphy of Continental Strata. American Association of Petroleum Geologists Bulletin, 78: 544-568. 
VAIL, P.R. 1987. Seismic stratigraphy interpretation using sequence stratigraphy, Part 1: seismic stratigraphy interpretation procedure. In: A.W., Bally (ed.). Atlas of Seismic Stratigraphy American Association of Petroleum Geologists Stud. Geol., 27: 1-10.

VAN WAGONER, J.C., POSAMENTIER, H.W., MITCHUM, R.M., VAIL, P.R., SARG, J.F., LOUTIT, T.S., HARDENBOL, T. 1988. An overview of the fundamentals of sequence stratigraphy and key definitions. , In: C.K., Wilgus, B.S., Hastings, C.G.St.C., Kendall, H.W., Posamentier, C.A., Ross \& J.C., Van Wagoner (eds.), Sea-Level Changes: an integrated approach. Society of Economic Paleontologists and Mineralogists, Special Publication, 42 : 39-45.

WHITE, D.A. 1980. Assessing oil and gas Plays in Facies-Cycle Wedges. The American Association of Petroleum Geologists Bulletin, 64: 1158-1178. 


\section{ANEXO \\ RELAÇÃO DOS AFLORAMENTOS ESTUDADOS}

\begin{tabular}{|l|l|l|}
\hline Rio & Lapão & Descrição \\
\hline Pontos & Coordenadas (UTM) & Vista geral (morro da torre) \\
\hline La1 & $239,35 / 8610,95$ & Casa abandonada \\
\hline La2 & $237,95 / 8611,6$ & Casa de Moisés \\
\hline La3 & $237,85 / 8612$ & Rio Lapão \\
\hline La4 & $237,9 / 8612,85$ & Arenito \\
\hline La4A & $237,8 / 8612,7$ & Caminho p/a gruta do Lapão \\
\hline La5 & $237,55 / 8613,2$ & Arenito eólico sotoposto ao C \\
\hline La6 & $238,3 / 8613,1$ & Boca da gruta do Lapão \\
\hline La7 & $238,35 / 8612,8$ & Saida da gruta \\
\hline La8 & $238,85 / 8612,45$ & Arenito litorâneo-Rio Lapão \\
\hline La9 & $241,2 / 8612,25$ & Tempestitos \\
\hline La10 & $241,1 / 8612,3$ & Arenito fluvial-Rio Lapão \\
\hline La11 & $240,9 / 8612,5$ & Arenito fluvial-Rio Lapão \\
\hline La12 & $240,65 / 8612,5$ & Arenito fluvial-Rio Lapão \\
\hline La13 & $240,1 / 8612,5$ & Conglomerado \\
\hline La14 & $239,95 / 8612,35$ & Arenito com laminação plano-paralela \\
\hline La15 & $239,6 / 8612,3$ & Arenito com laminação plano-paralela \\
\hline La16 & $239,4 / 8612,2$ & Conglomerado \\
\hline La17 & $238,7 / 8612,3$ & \\
\hline
\end{tabular}

\begin{tabular}{|l|l|l|}
\hline Rio & Capivara \\
\hline Pontos & Coordenadas (UTM) & Descrição \\
\hline Ca1 & $241,5 / 8603,45$ & Foz do rio-arenito eólico \\
\hline Ca2 & $240,9 / 8603,6$ & Começo do perfil - conglomerado \\
\hline
\end{tabular}

\begin{tabular}{|l|l|l|}
\hline Morro & da Bacia & \\
\hline Pontos & Coordenadas (UTM) & Descrição \\
\hline Mb1 & $8621,45 / 229,85$ & Arenito eólico \\
\hline Mb2 & $230,1 / 8621,5$ & Arenito fluvial \\
\hline
\end{tabular}

\begin{tabular}{|l|l|l|}
\hline \multicolumn{2}{|l|}{ Riachinho } \\
\hline Pontos & Coordenadas (UTM) & Descrição \\
\hline Ria1 & $226,676 / 8608,925$ & Conglomerado \\
\hline
\end{tabular}




\begin{tabular}{|c|c|c|}
\hline Rio & Lençóis & \\
\hline Pontos & Coordenadas (UTM) & Descrição \\
\hline Le1 & $240,35 / 8610,2$ & Ponte sobre o Rio Lençóis em Lençóis \\
\hline Le2 & $239,9 / 8610,2$ & 1- Siltito marinho/Lençóis \\
\hline Le3 & $239,6 / 8609,85$ & Lençóis/tanque de decantação \\
\hline Le4 & $238,7 / 8610,35$ & Mirante/embaixo da Pedra do Navio \\
\hline Le4A & $238,7 / 8610,45$ & $\begin{array}{l}\text { Dique a montante da foz do Rio } \\
\text { Grisante }\end{array}$ \\
\hline Le4B & $238,6 / 8610,5$ & Inversão do mergulho do arenito eólico \\
\hline Le5A & $238,3 / 8610,55$ & Arenito fluvial \\
\hline Le5B & $238,2 / 8610,6$ & Arenito fluvial \\
\hline Le6A & $237,9 / 8610,75$ & Conglomerado \\
\hline Le6B & $237,8 / 8610,8$ & Conglomerado e arenito intercalados \\
\hline Le7A & $237,7 / 8610,9$ & Conglomerado \\
\hline Le7B & $237,65 / 8610,95$ & Arenito e conglomerado \\
\hline Le8 & $237,5 / 8611$ & Arenito e conglomerado \\
\hline Le9A & $237,4 / 8611,2$ & $\begin{array}{l}\text { Subindo o morro na margem do Rio } \\
\text { Lençóis }\end{array}$ \\
\hline Le9B & $237,35 / 8611,3$ & Arenito eólico e fluvial \\
\hline Le10 & $237,4 / 8611,4$ & Topo do morro - Conglomerado \\
\hline Le11 & $237,45 / 8611,6$ & Conglomerado \\
\hline Le12 & $238,1 / 8611,05$ & Topo do morro - Conglomerado \\
\hline Le13 & $238,5 / 8610,75$ & $\begin{array}{l}\text { Trilha da descida do morro em direção } \\
\text { ao Rio Lençóis - próximo a material } \\
\text { inconsolidado }\end{array}$ \\
\hline Le14 & $238,7 / 8610,55$ & Vista da Cachoeira da Primavera \\
\hline Le15 & $239,0 / 8610,2$ & $\begin{array}{l}\text { Trilha junto ao Rio Lençóis - dique de } \\
\text { vulcânica }\end{array}$ \\
\hline Le16 & $239,05 / 8610$ & Cachoeirinha \\
\hline Le17 & $238,75 / 8609,5$ & Cachoeirinha - Conglomerado \\
\hline Le18 & $239,3 / 8609,8$ & Base do conglomerado \\
\hline Le19 & $239,75 / 8610,05$ & Ar. sobre conglomerado \\
\hline Le20 & $240,7 / 8610,05$ & Tempestitos \\
\hline Le21 & $240,8 / 8609,75$ & Formação Caboclo \\
\hline Le22 & $238,5 / 8610,2$ & $\begin{array}{l}\text { Em cima da Cachoeira da } \\
\text { Primavera/Grisante }\end{array}$ \\
\hline Le23 & $239,7 / 8609,7$ & Hotel Portal de Lençóis \\
\hline Le24 & $239,3 / 8609,6$ & $\begin{array}{l}\text { Brecha sobre siltito roxo - trilha } \\
\text { Lençóis/Capão }\end{array}$ \\
\hline Le25 & $238,6 / 8609,4$ & $\begin{array}{l}\text { Conglomerado no topo da Cahoeirinha } \\
\text { - trilha Lençóis/Capão }\end{array}$ \\
\hline Le26 & $238,1 / 8609,5$ & $\begin{array}{l}\text { Escarpa de conglomerado sobre } \\
\text { arenito - trilha Lençóis/Capão }\end{array}$ \\
\hline Le27 & $237,6 / 8609,3$ & $\begin{array}{l}\text { Contato conglomerado sobre arenito - } \\
\text { trilha Lençóis/Capão }\end{array}$ \\
\hline Le28 & $237,2 / 8609.3$ & $\begin{array}{l}\text { Arenito eólico no chão - trilha } \\
\text { Lençóis/Capão }\end{array}$ \\
\hline Le29 & $236,95 / 8609,2$ & Drenagem - trilha Lençóis/Capão \\
\hline Le30 & $236,6 / 8608,9$ & Arenito fluvial - trilha Lençóis/Capão \\
\hline
\end{tabular}




\begin{tabular}{|c|c|c|}
\hline Rio & Ribeirão & \\
\hline Pontos & Coordenadas (UTM) & Descrição \\
\hline Rio & $240,2 / 8609,05$ & $\begin{array}{l}\text { Início da trilha } \mathrm{p} / \text { a Cachoeira do } \\
\text { Sossego conglomerado }\end{array}$ \\
\hline Ri1 & $240,91 / 8607,36$ & Foz do Ribeirão de Baixo $(\approx 360 \mathrm{~m})$ \\
\hline $\mathrm{Ri} 2$ & $240,65 / 8607,25$ & $\begin{array}{l}\text { Entre o Ribeirão de Baixo e o do Meio } \\
\text { - Arenito }\end{array}$ \\
\hline Ri3 & $240,35 / 8607,3$ & Brecha $(\approx 400 \mathrm{~m})$ \\
\hline Ri4 & $240,0 / 8607,7$ & $\begin{array}{l}\text { Trilha p/ a Cachoeira do Sossego } \\
\text { conglomerado }\end{array}$ \\
\hline Ri5 & $239,7 / 8607,35$ & Córrego da Onça - rocha básica \\
\hline Ri6 & $239,1 / 8607,1$ & $\begin{array}{l}\text { Rio ao lado do bar do Abílio/Arenito } \\
\text { eólico em contato por falha } 15^{\circ} \mathrm{c} / \mathrm{O} \mathrm{C}\end{array}$ \\
\hline Ri6A & $239,35 / 8607,15$ & Topo do conglomerado \\
\hline $\mathrm{Ri} 7$ & $238,85 / 8606,95$ & $\begin{array}{l}\text { Topo do conglomerado inferior - } \\
\text { Contato por falha } 45^{\circ}\end{array}$ \\
\hline Ri8 & $238.5 / 8606,85$ & Base do conglomerado inferior \\
\hline Ri9 & $238,2 / 8606,6$ & Próximo ao cânion \\
\hline Ri10 & $237 / 8606,75$ & Cachoeira do Sossego \\
\hline Ri11 & $239,8 / 8607,3$ & $\begin{array}{l}\text { Foz do Córrego da Onça - rio } \\
\text { seco/Arenito eólico }\end{array}$ \\
\hline Ri12 & $239,4 / 8607,5$ & $\begin{array}{l}\text { Base do } \\
\text { superior/próximo à cabeceira do } \\
\text { Córrego da Onça }\end{array}$ \\
\hline Ri13 & $236,25 / 8608,6$ & Trilha Capão/Lençóis \\
\hline Ri14 & $235,25 / 8610,4$ & Trilha Capão/Lençóis/junto à drenagem \\
\hline Ri15 & $234,7 / 8610$ & Trilha Capão/Lençóis \\
\hline Ri16 & $234,35 / 8610,4$ & Trilha Capão/Lençóis \\
\hline Ri17 & $233,55 / 8610,55$ & $\begin{array}{l}\text { Trilha Capão/Lençóis/cruzando o Rio } \\
\text { Ribeirão }\end{array}$ \\
\hline Ri18 & $231,9 / 8611,3$ & Trilha Capão/Lençóis \\
\hline Ri19 & $230,8 / 8612,2$ & $\begin{array}{l}\text { Trilha Capão Lençóis - em frente ao } \\
\text { Morrão }\end{array}$ \\
\hline Ri20 & $238 / 8606,45$ & $\begin{array}{l}\text { Morrão com conglomerado inferior } \\
\text { espesso (avista-se o Sossego) }\end{array}$ \\
\hline
\end{tabular}




\begin{tabular}{|c|c|c|}
\hline Rio & Mucugezinho & \\
\hline Pontos & $\begin{array}{l}\text { Coordenadas } \\
\text { (UTM) }\end{array}$ & Descrição \\
\hline Mu1 & $239 / 8620,8$ & BR-242 - conglomerado e arenito rítmico \\
\hline Mu1A & $238,8 / 8620,85$ & BR-242/arenito deltaico \\
\hline Mu2 & $238,7 / 8620,9$ & $4^{\circ}$ conglomerado - acesso \\
\hline Mu3 & $238,5 / 8620,9$ & $\begin{array}{l}\text { Entre } 3 \text { - e 4- arenito conglomerático c/ intercalação } \\
\text { de siltito }\end{array}$ \\
\hline Mu4 & $238,2 / 8620 ., 85$ & BR-242/próximo ao $4^{\circ}$ conglomerado \\
\hline Mu5 & $237,50 / 8620,6$ & $\begin{array}{l}\text { BR-242/2 conglomerado lantes do restaurante } \\
\text { Mucugezinho }\end{array}$ \\
\hline Mu6 & $237,1 / 8621$ & $\begin{array}{l}\text { BR-242/restaurante Mucugezinho/ar. litorâneo sob } \\
\text { fluvial }\end{array}$ \\
\hline Mu7 & $237,5 / 8621,15$ & Poço do Diabo/arenito fluvial - conglomerado no vale \\
\hline Mu8 & $235,1 / 8620,6$ & BR-242/próximo ao Rio Mucugezinho \\
\hline Mu8A & $235,4 / 8620,7$ & BR-242/bar do Pelé \\
\hline Mu9 & $234,8 / 8620,5$ & BR-242/próximo ao Rio Mucugezinho \\
\hline Mu10 & $234,35 / 8620,3$ & $\begin{array}{l}\text { BR-242/ponte sobre o Rio Mucugezinho/arenito } \\
\text { flúvio-estuário }\end{array}$ \\
\hline Mu10A & $234,6 / 8620,45$ & Arenito \\
\hline Mu11 & $231,1 / 8621,5$ & Morro do Pai Inácio. Início do perfil \\
\hline Mu12 & $231,7 / 8621,15$ & BR-242/posto próximo ao Morro do Pai Inácio \\
\hline Mu13 & $231,35 / 8621,35$ & Morro do Pai Inácio \\
\hline Mu14 & $229,85 / 8622,8$ & $\begin{array}{l}\text { Próximo a BR-242/Pedreira Cristalito/Arenitos } \\
\text { litorâneos }\end{array}$ \\
\hline Mu14A & $229,7 / 8622,8$ & Próximo a BR-242/acesso à pedreira Cristalito \\
\hline Mu15 & $236,7 / 8621,3$ & Rio Mucugezinho - Bar Cachoeira/arenito fluvial \\
\hline Mu15A & $236,75 / 8621,2$ & BR-242/acesso à Toca da Marina \\
\hline Mu16 & $234,6 / 8620,5$ & $\begin{array}{l}\text { Próximo a BR-242 - Rio Mucugezinho/base do } \\
\text { perfil/arenito fluvial }\end{array}$ \\
\hline Mu17 & $235,1 / 8620,7$ & Rio Mucugezinho/bar do Pelé/tobogã \\
\hline Mu18 & $238,3 / 8620,85$ & Início do Perfil (Mu 19A/Mu21) na BR-242 \\
\hline Mu19 & $8620,9 / 238,35$ & $\begin{array}{l}\text { Drenagem que corta a BR-242/3- conglomerado sob } \\
\text { arenito }\end{array}$ \\
\hline Mu19A & $238,25 / 8620,65$ & Morro ao lado da BR-242/4- conglomerado \\
\hline Mu20 & $238,35 / 8620,5$ & $\begin{array}{l}\text { Morro ao lado da BR-242/siltito sobre } 5 \text { - } \\
\text { conglomerado }\end{array}$ \\
\hline Mu21 & $238,4 / 8620,3$ & Morro ao lado da BR-242/tempestitos \\
\hline Mu22 & $236,1 / 8620,9$ & $\begin{array}{l}\text { BR-242/arenito cl estratificação cruzada tabular } \\
\text { intercalado c/ ritmito (Mengão) }\end{array}$ \\
\hline Mu22A & $236,2 / 8620,9$ & $\begin{array}{l}\text { BR-242/arenito cl estratificação cruzada tabular } \\
\text { intercalado c/ ritmito (Mengão) }\end{array}$ \\
\hline $\begin{array}{l}\text { Mu23 } \\
\text { Mu24 }\end{array}$ & $\begin{array}{l}236,5 / 8621,1 \\
236,85 / 8621,15\end{array}$ & $\begin{array}{l}\text { BR-242/arenito flúvio-estuarino (Placa Portal) } \\
\text { BR-242/ar. fluvial sob ar. eólico }\end{array}$ \\
\hline Mu25 & $237,65 / 8620,65$ & Arenito sobre 2 - conglomerado \\
\hline Mu26 & $239,5 / 8621,3$ & Arenito eólico \\
\hline Mu26A & $239.6 / 8621,35$ & Arenito eólico \\
\hline Mu27 & $240 / 8621,2$ & Arenito fluvial \\
\hline Mu28 & $240,4 / 8621,4$ & Arenito fluvial com níveis de seixos \\
\hline Mu29 & $239,3 / 8621,8$ & Siltito/morro na margem direita do Rio Mucugezinho \\
\hline Mu30 & $239,45 / 8622$ & Ar. conglomerático " \\
\hline
\end{tabular}




\begin{tabular}{|c|c|c|}
\hline Mu31 & $239,1 / 8622,1$ & Contato siltito/arenito/" \\
\hline Mu32 & $238,9 / 8621,9$ & Arenito fluvial/ " \\
\hline Mu33 & $238,85 / 8621,6$ & Arenito fluvial/ " \\
\hline Mu34 & $239,2 / 8621,1$ & Dique de rocha básica verde - Rio Mucugezinho \\
\hline Mu35 & $239,2 / 8621,1$ & Brecha/margem direita do Rio Mucugezinho \\
\hline Mu36 & $237,85 / 8621,4$ & $\begin{array}{l}\text { Base do } 2-\text { conglomerado /margem esquerda do rio } \\
\text { Mucugezinho/morro em frente ao cânion }\end{array}$ \\
\hline Mu37 & $238,3 / 8621,5$ & $\begin{array}{l}\text { Base do } 2-\text { conglomerado /margem esquerda do Rio } \\
\text { Mucugezinho }\end{array}$ \\
\hline Mu38 & $238,55 / 8621,35$ & $\begin{array}{l}\text { Contato ar. fluvial sob o } 2 \text { conglomerado /margem } \\
\text { esquerda do Rio Mucugezinho }\end{array}$ \\
\hline Mu39 & $238,8 / 8621,3$ & $\begin{array}{l}\text { Duna sobre 2" conglomerado /leito do Rio } \\
\text { Mucugezinho }\end{array}$ \\
\hline Mu40 & $238,75 / 8621,15$ & Arenito eólico sob o $4^{-}$conglomerado \\
\hline Mu41 & $238,3 / 8621,25$ & Arenito - margem direita do Rio Mucugezinho \\
\hline Mu42 & $238,3 / 8621,1$ & $\begin{array}{l}\text { 3. conglomerado sobre arenito/margem direita do } \\
\text { Rio Mucugugezinho }\end{array}$ \\
\hline Mu43 & $237,5 / 8620,8$ & $\begin{array}{l}\text { Arenito litorâneo próximo ao bar Mucugezinho - na } \\
\text { drenagem }\end{array}$ \\
\hline Mu44 & $233,15 / 8620,5$ & Siltito transgressivo/Morro do Brejão \\
\hline Mu45 & $238,7 / 8621,1$ & Vista do 4- conglomerado \\
\hline Mu46 & $238,75 / 8620,95$ & $\begin{array}{l}\text { Siltito recoberto por } 4 \mathrm{~m} \text { de arenito com lâminas de } \\
\text { seixos }\end{array}$ \\
\hline Mu47 & $240,55 / 8621,4$ & $\begin{array}{l}\text { Descendo o Rio Mucugezinho - sedimentos } \\
\text { marinhos }\end{array}$ \\
\hline Mu48 & $240,7 / 8622$ & Descendo o Rio Mucugezinho. Marinho. Gutter cast \\
\hline Mu49 & $241,1 / 8622,3$ & $\begin{array}{l}\text { Final do Mucugezinho. Início do grande perfil que vai } \\
\text { até a ponte (Mu51) }\end{array}$ \\
\hline Mu50 & $241,5 / 8622,5$ & Final do Mucugezinho. Paredão/margem esquerda \\
\hline Mu51 & $241,85 / 8622,4$ & Ponte (final) do Mucugezinho \\
\hline Mu52 & $236,95 / 8620,6$ & $\begin{array}{l}\text { 2- conglomerado sobre ar. eólico (direita do Bar } \\
\text { Mucugezinho) }\end{array}$ \\
\hline Mu53 & $236,8 / 8620,07$ & $\begin{array}{l}\text { 2. conglomerado sobre arenito eólico (direita do Bar } \\
\text { Mucugezinho) }\end{array}$ \\
\hline Mu54 & $236,5 / 8620,8$ & Paredão $-13 m$ de arenito fluvial \\
\hline Mu55 & $237,0 / 8621,7$ & 1- $\mathrm{c}$-trilha do Brejão \\
\hline Mu55A & $237,1 / 8621,7$ & 1- $\mathrm{c}$ - tritha do Brejão \\
\hline Mu56 & $242 / 8622,35$ & Abaixo da ponte sobre o Rio Mucugezinho \\
\hline Mu57 & $242,05 / 8622,6$ & Abaixo da ponte sobre o Rio Mucugezinho \\
\hline Mu58 & $236,95 / 8621,35$ & Rio Mucugezinho/Toca da Marina \\
\hline Mu59 & $237,05 / 8621,15$ & $\begin{array}{l}\text { Rio Mucugezinho/Toca da Marina/contato arenito } \\
\text { eólico/fluvial }\end{array}$ \\
\hline Mu60 & $234,75 / 8620$ & Morro ao sul da ponte \\
\hline Mu61 & $234,9 / 8620$ & Arenito \\
\hline Mu62 & $234,8 / 8619,9$ & Arenito \\
\hline Mu63 & $234,6 / 8620,4$ & Topo do perfil da ponte \\
\hline
\end{tabular}




\begin{tabular}{|c|c|c|}
\hline Rio & Mandassaia & \\
\hline Pontos & $\begin{array}{l}\text { Coordenadas } \\
\text { (UTM) }\end{array}$ & Descrição \\
\hline Ma1 & $241,7 / 8614,5$ & $\begin{array}{l}\text { Foz do rio Mandassaia. Arenito c/ marca de } \\
\text { onda }\end{array}$ \\
\hline Ma2 & $241,4 / 8614,55$ & Tempestitos \\
\hline Ma3 & $241,01 / 8614,61$ & Tempestitos \\
\hline Ma4 & $240,739 / 8614,554$ & Contato arenito fluvial/arenito eólico \\
\hline Ma5 & $240,5 / 8614,7$ & Arenito com laminação plano-paralela \\
\hline Ma6 & $240,05 / 8614,85$ & Arenito com seixo e brecha \\
\hline Ma6A & $239,85 / 8614,9$ & Soleira \\
\hline Ma7 & $239,7 / 8615,7$ & $\begin{array}{l}\text { Arenito com laminação plano-paralela (eólico?) } \\
\text { cortado por canal fluvial }\end{array}$ \\
\hline Ma8 & $239,5 / 8615,0$ & Arenito eólico \\
\hline Ma9 & $239,3 / 8615,1$ & Topo do conglomerado \\
\hline Ma10 & $239,2 / 8615,2$ & Conglomerado \\
\hline Ma11 & $236,7 / 8615,05$ & Trilha Barro Branco/Lençóis \\
\hline Ma12 & $237,05 / 8614,9$ & Trilha cruzando outra trilha \\
\hline Ma13 & $236,9 / 8615,2$ & Conglomerado \\
\hline Ma14 & $236,75 / 8615,5$ & Conglomerado sobre arenito eólico \\
\hline Ma15 & $237,0 / 8615,3$ & Conglomerado \\
\hline Ma16 & $237,25 / 8615,3$ & Arenito eólico \\
\hline Ma17 & $237,55 / 8615,20$ & Arenito eólico - estria de quartzo \\
\hline Ma18 & $237,8 / 8615,2$ & Duna eólica \\
\hline Ma19 & $238,0 / 8615,15$ & Duna eólica \\
\hline Ma20 & $238,25 / 8615,1$ & Arenito \\
\hline Ma21 & $238,50 / 8615,1$ & Conglomerado sobre arenito eólico \\
\hline Ma22 & $238,6 / 8615,1$ & Conglomerado e arenito \\
\hline Ma23 & $238,75 / 8615,1$ & Conglomerado e arenito \\
\hline Ma24 & $240,45 / 8612,6$ & Trilha Lapão/Lençóis \\
\hline Ma25 & $240,45 / 8612,55$ & Cruzando o Rio Lapão \\
\hline Ma26 & $233,6 / 8619,1$ & Contato formações. Guiné e Tombador \\
\hline Ma27 & $233,8 / 8618,7$ & Em frente ao paredão \\
\hline Ma28 & $234,1 / 8618,2$ & Divisor de drenagem \\
\hline Ma29 & $234,3 / 8617,6$ & Arenito \\
\hline Ma30 & $234,9 / 8616,7$ & Arenito \\
\hline Ma31 & $235,1 / 8616,4$ & Arenito \\
\hline Ma32 & $235,4 / 8616,1$ & Arenito \\
\hline Ma33 & $235,8 / 8615,6$ & Cruzando o Rio Mandassaia \\
\hline Ma34 & $236,2 / 8615,4$ & 1- conglomerado sobre arenito eólico \\
\hline Ma35 & $236,6 / 8615,3$ & 1- conglomerado \\
\hline Ma36 & $236,8 / 8615,5$ & 1 - conglomerado \\
\hline Ma37 & $235,5 / 8615,6$ & Arenito \\
\hline Ma38 & $235,2 / 8615,9$ & Arenito \\
\hline Ma39 & $234,9 / 8616,1$ & Arenito \\
\hline Ma40 & $235 / 8616,3$ & Arenito \\
\hline Ma41 & $235,2 / 8616,4$ & Arenito \\
\hline
\end{tabular}




\begin{tabular}{|c|c|c|}
\hline Rio & Mandassaia & \\
\hline Pontos & $\begin{array}{l}\text { Coordenadas } \\
\text { (UTM) }\end{array}$ & Descrição \\
\hline Ma1 & $241,7 / 8614,5$ & $\begin{array}{l}\text { Foz do rio Mandassaia. Arenito } \mathrm{c} / \text { marca de } \\
\text { onda }\end{array}$ \\
\hline Ma2 & $241,4 / 8614,55$ & Tempestitos \\
\hline Ma3 & $241,01 / 8614,61$ & Tempestitos \\
\hline Ma4 & $240,739 / 8614,554$ & Contato arenito fluvial/arenito eólico \\
\hline Ma5 & $240,5 / 8614,7$ & Arenito com laminação plano-paralela \\
\hline Ma6 & $240,05 / 8614,85$ & Arenito com seixo e brecha \\
\hline Ma6A & $239,85 / 8614,9$ & Soleira \\
\hline Ma7 & $239,7 / 8615,7$ & $\begin{array}{l}\text { Arenito com laminação plano-paralela (eólico?) } \\
\text { cortado por canal fluvial }\end{array}$ \\
\hline Ma8 & $239,5 / 8615,0$ & Arenito eólico \\
\hline Ma9 & $239,3 / 8615,1$ & Topo do conglomerado \\
\hline Ma10 & $239,2 / 8615,2$ & Conglomerado \\
\hline Ma11 & $236,7 / 8615,05$ & Trilha Barro Branco/Lençóis \\
\hline Ma12 & $237,05 / 8614,9$ & Trilha cruzando outra trilha \\
\hline Ma13 & $236,9 / 8615,2$ & Conglomerado \\
\hline Ma14 & $236,75 / 8615,5$ & Conglomerado sobre arenito eólico \\
\hline Ma15 & $237,0 / 8615,3$ & Conglomerado \\
\hline Ma16 & $237,25 / 8615,3$ & Arenito eólico \\
\hline Ma17 & $237,55 / 8615,20$ & Arenito eólico - estria de quartzo \\
\hline Ma18 & $237,8 / 8615,2$ & Duna eólica \\
\hline Ma19 & $238,0 / 8615,15$ & Duna eólica \\
\hline Ma20 & $238,25 / 8615,1$ & Arenito \\
\hline Ma21 & $238,50 / 8615,1$ & Conglomerado sobre arenito eólico \\
\hline Ma22 & $238,6 / 8615,1$ & Conglomerado e arenito \\
\hline Ma23 & $238,75 / 8615,1$ & Conglomerado e arenito \\
\hline Ma24 & $240,45 / 8612,6$ & Trilha Lapão/Lençóis \\
\hline Ma25 & $240,45 / 8612,55$ & Cruzando o Rio Lapão \\
\hline Ma26 & $233,6 / 8619,1$ & Contato formações. Guiné e Tombador \\
\hline Ma27 & $233,8 / 8618,7$ & Em frente ao paredão \\
\hline Ma28 & $234,1 / 8618,2$ & Divisor de drenagem \\
\hline Ma29 & $234,3 / 8617,6$ & Arenito \\
\hline Ma30 & $234,9 / 8616,7$ & Arenito \\
\hline Ma31 & $235,1 / 8616,4$ & Arenito \\
\hline Ma32 & $235,4 / 8616,1$ & Arenito \\
\hline Ma33 & $235,8 / 8615,6$ & Cruzando o Rio Mandassaia \\
\hline Ma34 & $236,2 / 8615,4$ & 1 - conglomerado sobre arenito eólico \\
\hline Ma35 & $236,6 / 8615,3$ & 1 - conglomerado \\
\hline Ma36 & $236,8 / 8615,5$ & 1- conglomerado \\
\hline Ma37 & $235,5 / 8615,6$ & Arenito \\
\hline Ma38 & $235,2 / 8615,9$ & Arenito \\
\hline Ma39 & $234,9 / 8616,1$ & Arenito \\
\hline Ma40 & $235 / 8616,3$ & Arenito \\
\hline Ma41 & $235,2 / 8616,4$ & Arenito \\
\hline
\end{tabular}

